Piskóti Marianna

\title{
A KÖRNYEZETI IDENTITÁS SZEREPE A KÖRNYEZETTUDATOS VISELKEDÉS KIALAKULÁSÁBAN
}




\title{
MARKETING ÉS MÉDIA INTÉZET
}

\section{MARKETINGKUTATÁS ÉS FOGYASZTÓI MAGATARTÁS TANSZÉK}

Témavezető:

\author{
Dr. Hofmeister-Tóth Ágnes
}

Egyetemi Tanár

(C) Piskóti Marianna 
BUDAPESTI CORVINUS EGYETEM

Gazdálkodástani Doktori Iskola

\section{A KÖRNYEZETI IDENTITÁS SZEREPE A KÖRNYEZETTUDATOS VISELKEDÉS KIALAKULÁSÁBAN}

Doktori értekezés

Piskóti Marianna

Budapest, 2015. 


\section{TARTALOMJEGYZÉK}

ÁBRAJEGYZÉK.........................................................................................................................III

TÁBLÁZATJEGYZÉK ..................................................................................................

KÖSZÖNETNYILVÁNÍTÁS.........................................................................................................

1 BEVEZETÉS .......................................................................................................................... 1

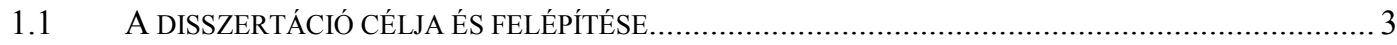

2 FENNTARTHATÓ FOGYASZTÁS............................................................................5

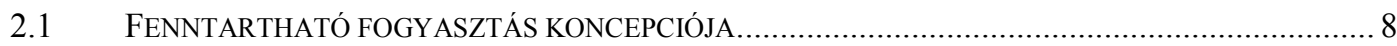

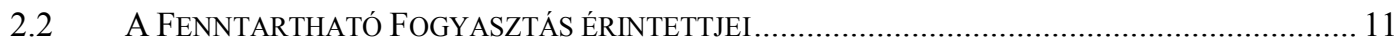

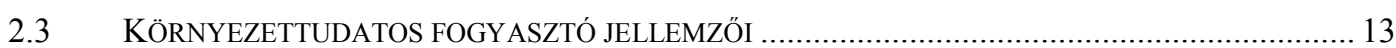

3 A PSZICHOLÓGIA IRÁNYZATAINAK ÉRTELMEZÉSE A KÖRNYEZETTUDATOS

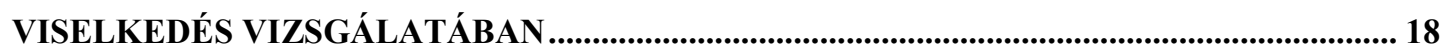

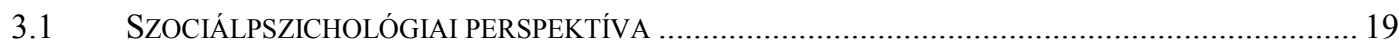

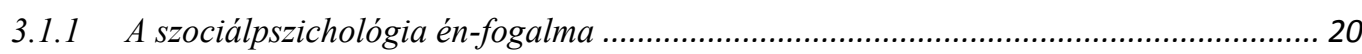

3.1.2 A Szociálpszichológia alkalmazása a környezetbarát tevékenységek megértésére......... 21

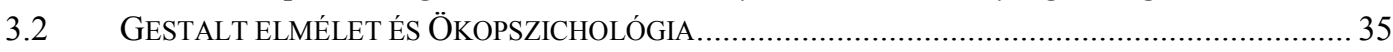

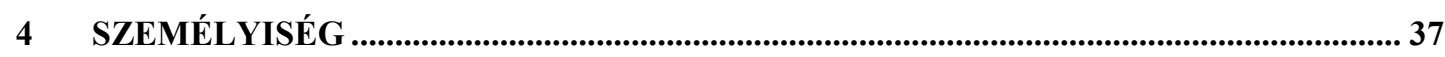

4.1 A TÁRSAS KAPCSOLATOK JELENTŐSÉGE, A SZIMBOLIKUS INTERAKCIONIZMUS....................... 40

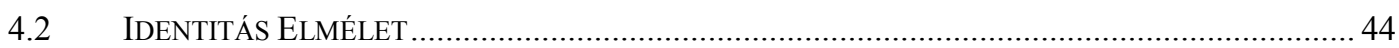

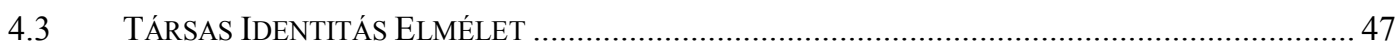

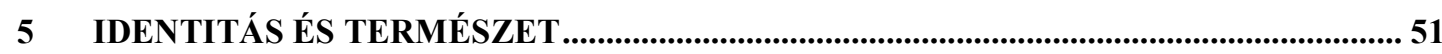

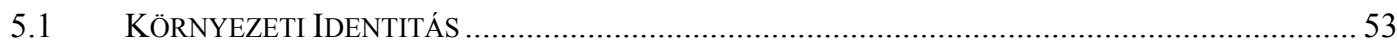

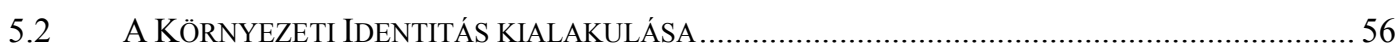

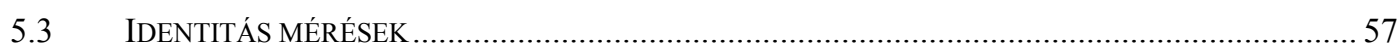

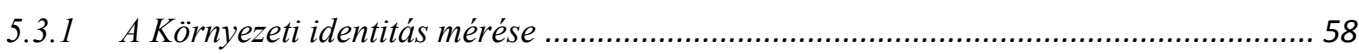

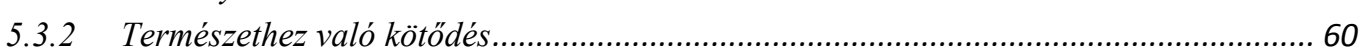

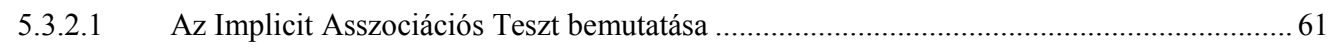

5.3.2.2 IAT- Nature teszt az egyén és a környezet kapcsolatának vizsgálatára................................... 66

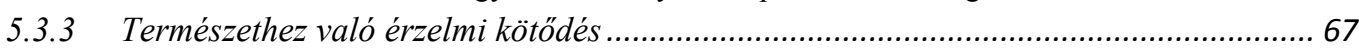

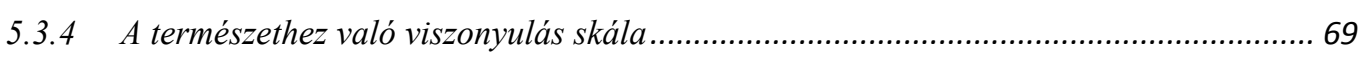

5.4 IDENTITÁS, MINT A FOGYASZTÓI VISELKEDÉS ALAKÍTÓ TÉNYEZÖJE ....................................... 70

6 A KÖRNYEZETTUDATOS FOGYASZTÁS TERÜLETÉN ALKALMAZOTT FOGYASZTÓI MAGATARTÁS MODELLEK ……............................................................... 75

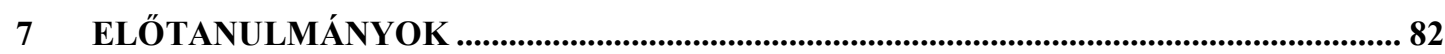

7.1 KVALITATÍV KUTATÁS A TERMÉSZETHEZ VALÓ KÖTÖDÉS VIZSGÁLATÁRA …......................... 82

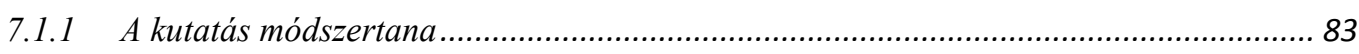

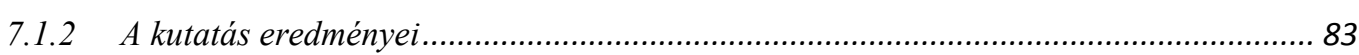

7.1.3 Az eredmények összefoglalása és a kutatás korlátai................................................... 88

7.2 KVANTITATÍV KUTATÁS A KÖRNYEZETI IDENTITÁS MÉRÉSÉRE ALKALMAS SKÁLÁK

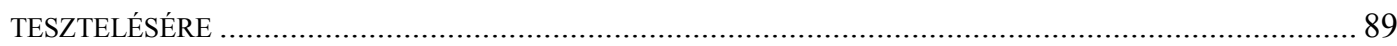

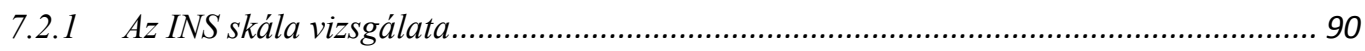

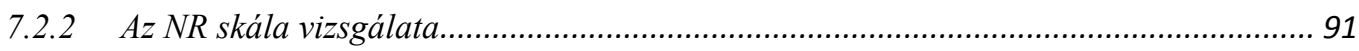

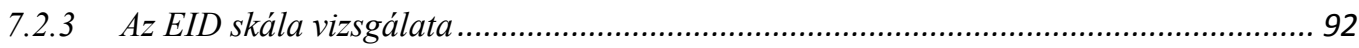




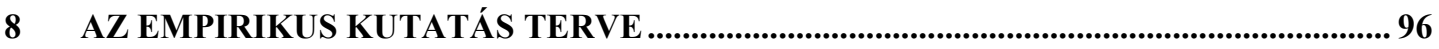

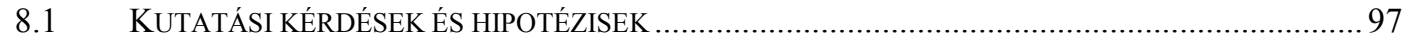

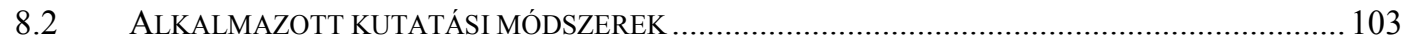

8.2.1 Implicit Asszociációs Teszt - Nature ...................................................................... 103

8.2.2 A környezeti identitás és a környezettudatos viselkedés kapcsolatának vizsgálata....... 104

9 IAT-NATURE ALKALMAZÁSA A TERMÉSZET ÉS AZ EGYÉN KAPCSOLATÁNAK

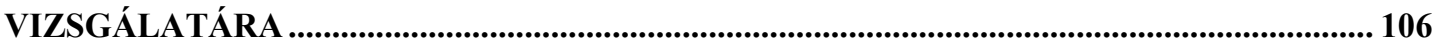

9.1 KUTATÁS ESZKÖZEINEK ÉS INGERANYAGAINAK BEMUTATÁSA ....................................... 106

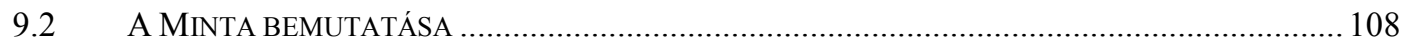

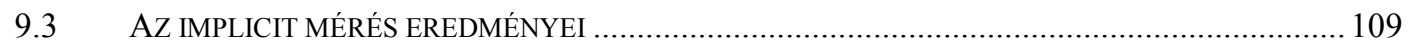

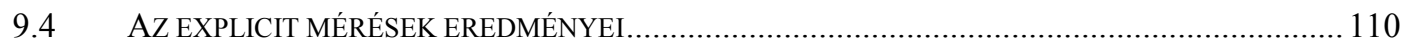

9.5 AZ IMPLICIT ÉS AZ EXPLICIT MÉRÉSEK KAPCSOLATA …................................................ 112

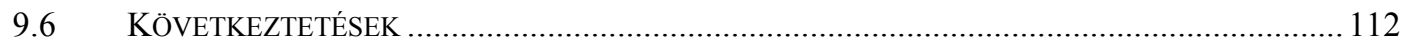

10 A KÖRNYEZETI IDENTITÁS ÉS A KÖRNYEZETTUDATOS VISELKEDÉS

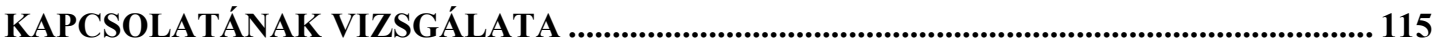

10.1 A KUTATÁS CÉLJA ÉS KÖRÜLMÉNYEI .......................................................................... 115

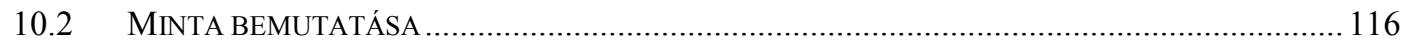

10.3 KÖRNYEZETI IDENTITÁS SKÁLA MEGBÍZHATÓSÁGA.................................................... 117

10.4 A KÖRNYEZETI IDENTITÁS SKÁLA DEMOGRÁFIAI MEGHATÁROZÓ TÉNYEZŐI ...................... 122

10.5 AZ ÉRTÉKEK HATÁSA A KÖRNYEZETI IDENTITÁSRA ................................................... 128

10.6 ÚTELEMZÉS: A KÖRNYEZETI IDENTITÁS HATÁSA A KÖRNYEZETBARÁT VISELKEDÉSRE ..... 131

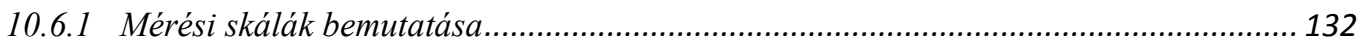

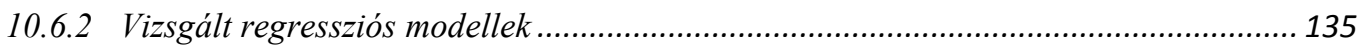

10.6.3 Kutatási eredmények összegzése ....................................................................... 143

11 EREDMÉNYEK ÉRTÉKELÉSE, KÖVETKEZTETÉSEK …........................................ 146

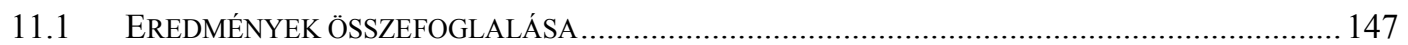

11.2 A KÖRNYEZETI IDENTITÁS MÉRÉSÉRE VONATKOZÓ KÖVETKEZTETÉSEK........................... 153

11.3 A KÖRNYEZETI IDENTITÁS VIZSGÁLATÁNAK ELMÉLETI ÉS GYAKORLATI JELENTŐSÉGE..... 156

11.4 KUTATÁS KORLÁTAI ÉS JÖVÖBENI KUTATÁSI LEHETŐSÉGEK ........................................... 158

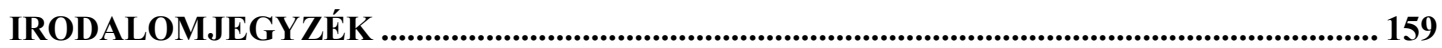

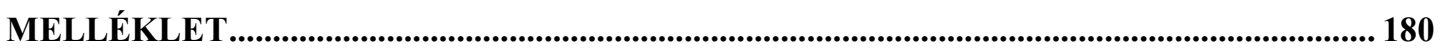



ÁBRAJEGYZÉK
1. ábra: A fenntartható fejlődés pilléreinek a kapcsolódása 6
2. ábra: A fenntartható fogyasztás stakeholderei .......................................................... 11

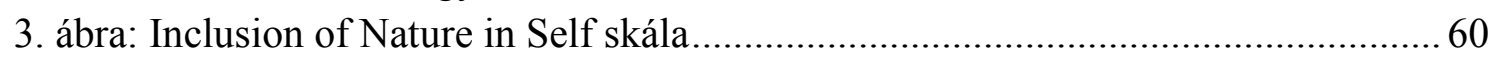

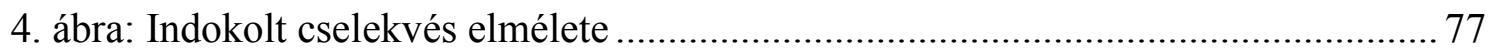

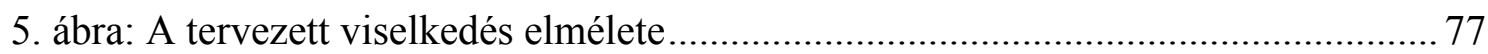

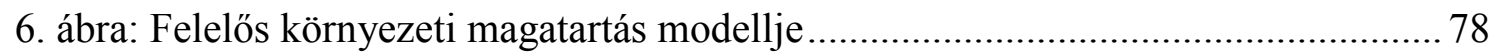

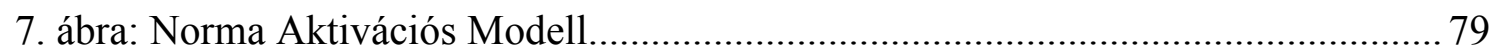
8. ábra: Érték - Hiedelem - Norma Modell................................................................. 80
9. ábra: A természet értelmezése pozitív és negatív esszékben együttesen .................... 84

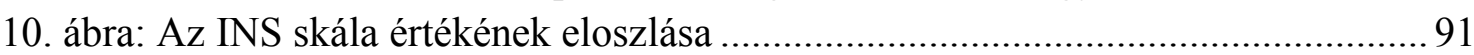

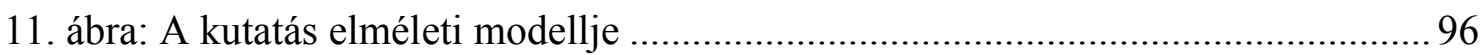
12. ábra: IAT-Nature teszt példa: kompatibilis, páros próba ....................................... 107

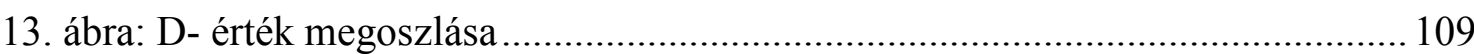
14. ábra: Interakció a Nem és a Családi állapot változók között ................................ 126
15. ábra: Interakció a Családi állapot és Gyermek léte változók között...................... 127

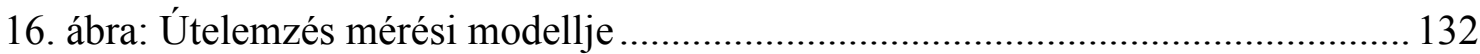
17. ábra: A környezettudatos viselkedés és a környezeti identitás összefüggésének útmodellje 


\section{TÁBLÁZATJEGYZÉK}

1. táblázat: A fenntartható fejlődés koncepció kialakulásának főbb állomásai ................ 7

2. táblázat: Az eredeti LOV és Rokeach értékskála összehasonlítása ............................ 24

3. táblázat: A bemutatott személyiségelméletek főbb jellemzői.................................... 40

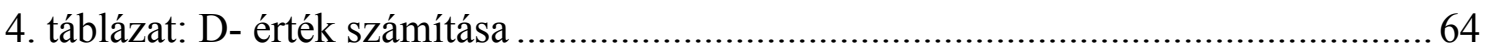

5. táblázat: A környezeti identitás dimenzióinak kódolási gyakorisága ......................... 86

6. táblázat: A természet és egyén közötti kapcsolatot vizsgáló skálák összefoglalása ...90

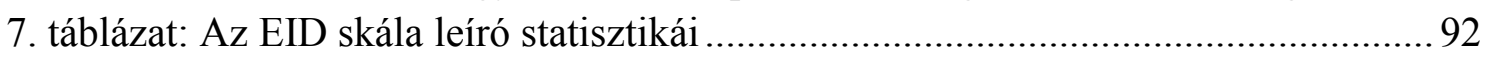

8. táblázat: Az EID skála belső konzisztenciája .......................................................... 93

9. táblázat: Az EID skálára végzett főkomponens-elemzés eredménye ......................... 94

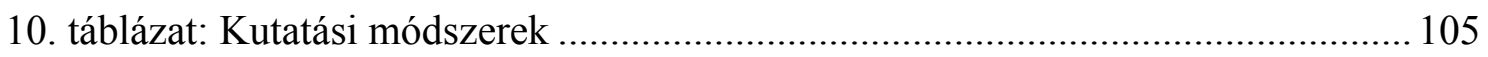

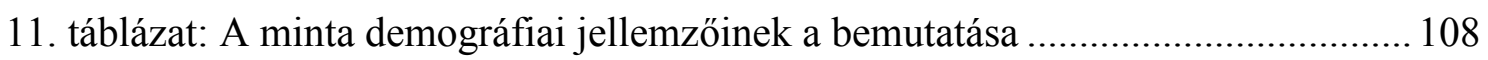

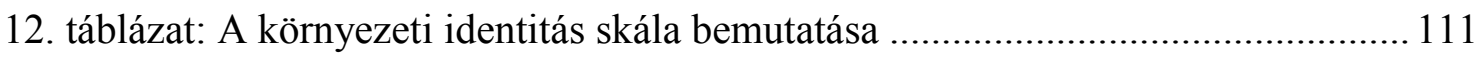

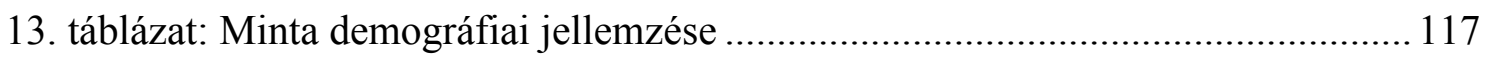

14. táblázat: Az EID skála leíró statisztikái ............................................................. 118

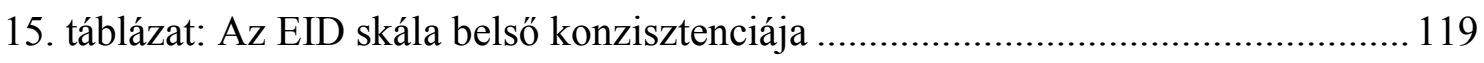

16. táblázat: A megerősítő faktor elemzés eredményei, a skála megbízhatósági és

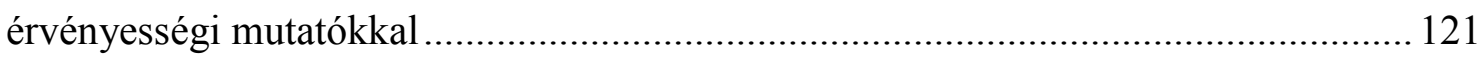

17. táblázat: Demográfiai különbségek a környezeti identitás értékeiben.................... 124

18. táblázat: Demográfiai változók hatása a környezeti identitásra, hierarchikus ANOVA

19. táblázat: LOV értékek átlagai a teljes mintára vonatkozóan .............................. 128

20. táblázat: Többváltozós lineáris regresszió eredményei az értékek környezeti

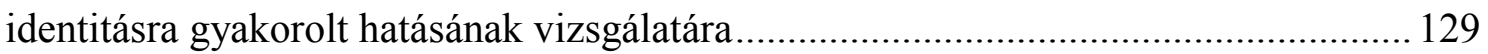

21. táblázat: Modellben alkalmazott skálák megbízhatósági vizsgálata...................... 133

22. táblázat: Többváltozós lineáris regresszió eredménye a környezettudatos viselkedés

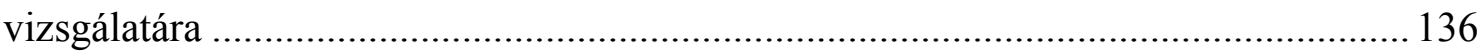

23. táblázat: Többváltozós lineáris regresszió eredménye a környezeti attitűd vizsgálatára 138

24. táblázat: Többváltozós lineáris regresszió eredménye a környezeti aggodalom

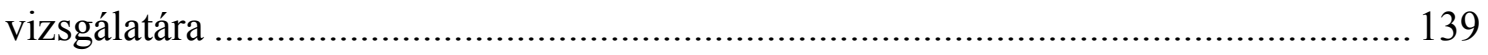

25. táblázat: Többváltozós lineáris regresszió eredménye a személyes norma vizsgálatára 141

26. táblázat: Regressziós útmodellhez kötődő hipotézis teszt eredmények.................. 144

27. táblázat: Hipotézis teszt eredményeinek az összegzése....................................... 153 


\section{KÖSZÖNETNYILVÁNÍTÁS}

Disszertációm megszületéséhez nyújtott támogatásáért sok kollégának, barátnak és családtagomnak tartozom köszönettel. Nagy szeretettel és szakmai tisztelettel gondolok Hofmeister-Tóth Ágnes témavezetőmre, aki a környezettudatosság témája felé irányította érdeklődésemet és számos kutatási program keretében szakmai iránymutatásával segítette egyéni kutatói tapasztalatszerzésemet. Köszönöm a bizalmát és támogatását a tudományos pályám során. Hálával tartozom Neulinger Ágnesnek, akihez mindig bizalommal fordulhattam dilemmáimmal, kérdéseimmel. Intézetvezetőmtől Simon Judittól, valamint tanszéki és intézeti kollégáimtól, doktorjelölt társaimtól is sok támogatást kaptam, mindig megvitathattam velük részeredményeimet és véleményükkel segítették a jó megoldások megtalálását. Munkájuk, szakmai elkötelezettségük követendő példát mutatott számomra és olyan közeget teremtett, amelyben örömmel dolgozom. Külön köszönöm KaszaKelemen Katának, hogy közös munkáinkban igazi csapatként, alkotótársként dolgoztunk együtt.

Családomnak azért tartozom köszönettel, mert megmutatták számomra a tudományos munka szépségét és értékét. Biztatásukkal és szeretetükkel folyamatosan mellettem álltak a hullámvölgyek alján és tetején is, lehetővé téve, hogy mindig lelkesedéssel induljak a kapott kihívások felé. 
„Miután reggel gondosan rendbe szedte magát az ember, gondosan rendbe kell szednie a bolygóját is."

Antoine de Saint-Exupéry

\section{BEVEZETÉS}

A modern korban kialakult individualizált társadalmunkban jelentősen megváltozott a közösség és az egyén viszonya. Az individualizálódás egyszerre lehet a modernizáció vívmánya és veszélye. A fogyasztói társadalom kényelme lehetővé teszi, hogy az egyének ne legyenek olyan mértékben egymásra utalva (Kiss és Pikó, 2004). Az individualista egyén természeti és társas környezethez való laza kötődése miatt - a társadalom-lélektan szerint - a Mead-i reflektív én nem tud a maga teljességében kifejlödni közösségi interakciók nélkül. A közösség érzésének hiánya miatt elfelejtjük, hogy nemcsak önmagunkat kell rendben tartani, fejleszteni, hanem a környezetünket is, legyen szó a társas kapcsolatainkról vagy a természetről, vagy a bolygónkról.

Az állampolgárok környezetbarát illetve környezetkárosító viselkedésének vizsgálatáról készült kutatások az elmúlt években enyhe pozitív tendenciát mutatnak a környezetbarát fogyasztói viselkedés erősödése irányában (National Geographics és Globescan, 2012, 2014) Ezeket a változásokat azonban alapvetően nemcsak a fogyasztók környezettudatosabb gondolkodása indította el, hanem a gazdasági változások, az anyagi megfontolások, és a költséghatékonyabb háztartás-vezetés. Emiatt a környezetbarát tevékenységek leginkább az energiahatékonyság növekedésében, és az energiafogyasztás csökkentésében jelentek meg a háztartások életében.

A gazdasági válság hatása két irányból hatott a lakosságra. Pozitív hatása, hogy erősödött a takarékosság, de negatív következménye, hogy a lakosság szemében a környezeti problémák fontossága - mint a globális felmelegedés, légszennyezés, vízszennyezés, elsivatagosodás, biodiverzitás csökkenése, hulladék, stb. - lecsökkent. A Nielsen 2011es kutatása azt mutatta, hogy a gazdasági jólét illetve a létbiztonság kérdései - érthető módon - fontosabbá váltak, mint a környezetvédelem. A közöny mellett megjelentek a problémától való eltávolodás jelei - amelyet tekinthetünk problémakezelési módszernek is - abban, hogy az aggodalom hiányát a fogyasztók leginkább azzal indokolják, hogy a környezeti katasztrófák és problémák alapvetően nem az emberi viselkedés 
következményei (Nielsen, 2011). A 2014-es adatok a válság okozta negatív tendencia megtörését és a környezeti aggodalom erősödését jelzik, de a lakosság számára a környezeti problémák fontossága még mindig nem éri el a 2008-as mértéket (National Geographics és Globescan, 2014).

A lehető legkisebb mértékủ környezeti terhelést célzó, fenntartható fogyasztás azonban az állampolgárnál kezdődik (WEF, 2011). Az egyén a gazdaság központi szereplője, mint fogyasztó, befektető, döntéshozó és munkavállaló. A fogyasztói elköteleződés kulcsfontosságú a fenntartható fogyasztás kialakításában. Disszertációmban a fogyasztói elköteleződés kialakítását, mint a fenntartható fogyasztás meghatározó alapját helyezem a fókuszba.

Véleményem szerint a fenntartható fogyasztás akkor érhető el, ha a fenntarthatóság koncepciója egyaránt beépül az üzleti modellekbe, a termelésbe, és a fogyasztói gondolkodásmódba is a környezeti nevelés, a társadalmi marketing által. Ehhez a szereplök szélesebb körét kell összefogni, figyelembe kell venni a kormányzat, a vállalatok és a társadalmi szereplők (például a civil szervezetek) felelősségét is.

A fenntartható fogyasztás megközelítései, eltérhetnek abban, mely érintett csoport szerepét hangsúlyozzák erősebben, kit helyeznek a középpontba. A strukturalista szemléletmódot követők szerint az attitüd és a viselkedés a környezet struktúrája által irányított. Ha a gazdasági környezet a szabályozásokkal és a kínálattal a fenntartható fogyasztást támogatja, akkor ennek hatására a fogyasztói viselkedés is átalakul. A voluntarista megközelítés szerint a kontextus csak egy része a teljes rendszernek, és az attitüd és a viselkedés relatíve független a struktúrától (Dobson, 2007). Ez alapján az egyéni attitüddel, személyiségjellemzőkkel és az egyéni viselkedéssel is foglalkozni kell. Úgy gondolom a két szemlélet nem választható el egymástól, az egyéni elköteleződéshez — ahogyan a komplex magatartás modellek is kezelik -belső indíttatás és külső támogató közeg és infrastruktúra is kell. Disszertációmban azonban nincs lehetőségem mindkét irányvonalra kitérni, ezért az egyén személyes jellemzőire fókuszálok.

Környezeti állampolgárnak (Dobson, 2007) hívjuk azt az egyént, aki felismeri, hogy az egyéni érdekek által irányított viselkedés gyakran veszélyezteti a közjavak, mint a természet minőségét. A környezeti állampolgár nem csak a gazdasági ösztönzők miatt fogyaszt fenntartható módon, hanem a környezeti értékek iránti elköteleződés motiválja. 
A környezeti állampolgár a közjó érdekében köteleződik el. A morális viselkedés és az ebböl eredeztethető elégedettség támogatja a környezetbarát viselkedés kialakulását.

A környezetbarát viselkedés iránti elköteleződést elősegíti, ha az egyénben a természethez való tartozás érzése kialakul (Clayton, 2003). Ha az én-fogalmat a természeti világra is kiterjesztjük, akkor azokat a viselkedéseket, amelyek a természet pusztításához vezetnek, önpusztító viselkedésként éljük meg (Mayer és Frantz, 2004), ezért megpróbáljuk elkerülni. A környezeti identitás koncepciója - azaz annak mértéke, mennyire érezzük a természetet az énünk fontos részének (Clayton, 2003) - a környezettudatos viselkedés iránti elköteleződés erős befolyásoló változójának tekinthető ${ }^{1}$. Disszertációmban a környezeti identitás jelentőségét, környezetbarát viselkedésre gyakorolt hatását járom körbe annak érdekében, hogy feltárjam a környezeti identitás szerepét a környezetbarát tevékenységek, a fenntartható fogyasztás kialakulásában.

\subsection{A DISSZERTÁCIÓ CÉLJA ÉS FELÉPÍTÉSE}

Disszertációm során a fenntartható fejlődés elméletét keretrendszernek tekintve foglalkozom a fenntartható fogyasztással, azon belül is a környezetbarát fogyasztói viselkedés vizsgálatával. A 2. fejezet a fenntartható fogyasztás tartalmi elemzését adja.

A környezetbarát viselkedést meghatározó tényezők vizsgálatával kiemelten foglalkozik — többek között - a fogyasztói magatartás, a zöld marketing és a társadalmi marketing mellett a környezeti pszichológia is, eredményeik azonban nem mindig kerülnek kölcsönös felhasználásra, összekapcsolásra. A tudományterületek kutatási témái szorosan összefüggenek, ezért - mivel mindkét tudományterületen folytattam tanulmányaimat különösen fontosnak, elengedhetetlennek tartom, hogy a két területen elért eredményeket szintetizálva alkalmazzam a disszertációban.

A pszichológiai irányzatok értelmezését kiindulópontnak tekintem a környezetbarát viselkedés magyarázatára szolgáló pszichográfiai tényezők esetében. A dolgozatban kiinduló alapként a klasszikus pszichológiai irányzatok környezettudatossághoz és

\footnotetext{
${ }^{1}$ Disszertációmban az egyén és a természet kapcsolatára helyezem a hangsúlyt. Erre a kapcsolatra a későbbiekben párhuzamosan használom majd a következő megfogalmazásokat: a természeti környezethez való kötődés, a természethez való tartozás érzése, illetve a környezeti identitás fogalma (mint az egyén természettel bővített én-fogalma).
} 
személyiség elmélethez kötődő koncepcióit mutatom be (3.1 - 3.5 fejezetek). A fogyasztói magatartás kutatás koncepciói a környezetbarát viselkedések vizsgálatára alkalmas viselkedésmodellek értelmezése során épülnek be a disszertációba (6. fejezet). Ezek a modellek a tényezők három nagy kategóriáját vizsgálják:

- külső, szituációs tényezők;

- belső, pszichográfiai tényezők;

- demográfiai jellemzők.

A disszertáció a pszichográfiai tényezőkre fókuszál, azon belül is kiemelten a személyiségre, illetve a környezeti identitásra. A környezetbarát viselkedés kialakulásának kutatása esetében a személyiség szerepének a vizsgálatát (Davis és tsai., 2009; Dono és tsai., 2010; Hinds és Sparks, 2008) az attitüd és a valós viselkedés között fennálló rés (Csutora, 2012; Kraus, 1995; Vermeir és Verbeke, 2006) indokolja. A környezeti identitás koncepciójának megértése érdekében (4. fejezet) a hangsúly a személyiség kialakulásának elméleteire és marketing aspektusaira helyeződik, majd részletesen meghatározom a természet és az egyén kapcsolatának vizsgálati lehetőségeit és a környezeti identitás fogalmát (5. fejezet).

Kutatásom alapvető célja, hogy a környezeti identitást beépítse az alkalmazott magatartásmodellekbe, és vizsgálja a környezeti identitásnak a környezettudatos viselkedés mértékére gyakorolt hatását.

A disszertáció empirikus kutatásokat tartalmazó fejezetei (7 - 10. fejezet) során először a környezeti identitás mérési lehetőségeit vizsgálom, összevetve a direkt és az indirekt módszerek előnyeit és hátrányait. Az előtanulmányok megalapozták a Clayton - féle Környezeti Identitás skála (2003) alkalmazhatóságát, amelyet 2012-ben országos mintán vizsgáltam. A disszertációmban regressziós útmodell segítségével igazoltam a környezeti identitás közepesen erős közvetlen hatását a környezetbarát viselkedés mértékére, valamint a környezeti attitüdön, környezeti aggodalmon és személyes normán keresztüli közvetett hatását is (10. fejezet). A kutatás gyakorlati jelentősége, hogy a környezetbarát tevékenységek kialakulására irányuló társadalmi marketing kampányok fókuszába új tényező, a környezeti identitás bevonását veti fel és indokolja s a mérése, meghatározó tényezői, hatása, kapcsolódásai, összefüggései feltárásával magalapozza a marketingbeavatkozások jellegét, lehetséges súlypontjait. 


\section{FENNTARTHATÓ FOGYASZTÁS}

Jelen disszertációnak nem célja a fenntartható fejlődés részletes vizsgálata. Rövid bemutatása mégis azért szükséges, mert a fenntartható fejlődést a kutatás keretrendszerének tekintem, amelyből kiindulva a fenntartható fogyasztás koncepcióján belül is egy pillérre, a környezeti pillérre fókuszálva vizsgálható a környezettudatos fogyasztás. A disszertáció célja a fenntartható fogyasztás elérésének a támogatása a környezet iránti elköteleződés vizsgálatával, ezért a fejezetben a fenntartható fejlődés koncepciójának tömör bemutatása utána a fenntartható fogyasztásra és a fenntartható fogyasztás érintettjeire helyezem a hangsúlyt.

A fenntartható fejlődés ${ }^{2}$ megvalósítása az elmúlt több mint 20 évben erős vitákat generáló folyamattá vált (Szlávik, 2014). Kerekes (2012) szerint a probléma már abban gyökerezik, hogyan értelmezhető a fenntartható fejlődés fogalma. A fenntarthatóság szó értelmezése egyszerübb, jelentése valaminek a folyamatos létezésének a biztosítása. A fejlődés jelentésének értelmezése azonban többrétü, minőségi és mennyiségi növekedést is jelenthet. Ahogy Daly (1993) fogalmaz, meg kell különböztetni a növekedést - ami mennyiségbeli, méretbeli változást jelent - a fejlődéstől, amely minőségbeli változást jelent egy teljesebb és jobb állapot felé.

A koncepció körüli folyamatos viták ellenére, megfogalmazhatóak olyan általános elvek, amelyek állandó hangsúlyt képviselnek (Drexhage és Murphy, 2010):

- az egyenlőség és a méltányosság melletti elköteleződés, amely a világ szegényebb régiói számára fejlődési lehetőségek biztosítását, valamint a jövő generáció iránti felelős döntéshozatalt jelenti;

- a hosszú-távú gondolkodásmód;

- és a környezet, gazdaság és társadalom hármas összekapcsolása. A fenntartható fejlődés magába foglalja a három pillér integrálását, megértését és a komplex kapcsolatot szem előtt tartó cselekvést.

A fenntarthatóság három pillérét általában három egymást részlegesen átfedő körként szokás ábrázolni, amely egy konceptuálisan egyszerü modell. Hátránya azonban, hogy ezzel a három szektor elkülönülését is feltételezi a modell, mert csak kis átfedést mutat

\footnotetext{
${ }^{2}$ Fenntartható fejlődésnek tekintjük azt a „,fejlődést, amely biztosítja a jelen szükségleteinek a kielégítését anélkül, hogy meggátolná a jövő generációk szükségleteinek a kielégítését”.(ENSZ, 1987)
} 
(Giddings és tsai., 2002). Azt a nézetet támogatja, hogy a fenntartható fejlődés kategóriákra tagolva kezelhető és a három szektor között felmerülő átváltásokat lehet kezelni, a szektorok helyettesíthetik egymást (pl. a gazdasági fejlődés kompenzálhatja a környezeti terhelést). Ennek eredményeként a gazdasági pillér, vagy a stratégia alkotás során a környezeti pillér gyakran túlhangsúlyozott. A valóságban azonban a gazdaság a társadalomtól és a környezettől szorosan függ (Daly, 1992 idézi: Giddings et al., 2002). Giddings és munkatársai a fészek modellt javasolják az integrációt elősegítő konceptuális szemlélet kialakításához. Ebben az esetben már az ábrából is jól látható, hogy a gazdaság függ a társadalomtól és mind a kettő függ a környezettől (1. ábra).
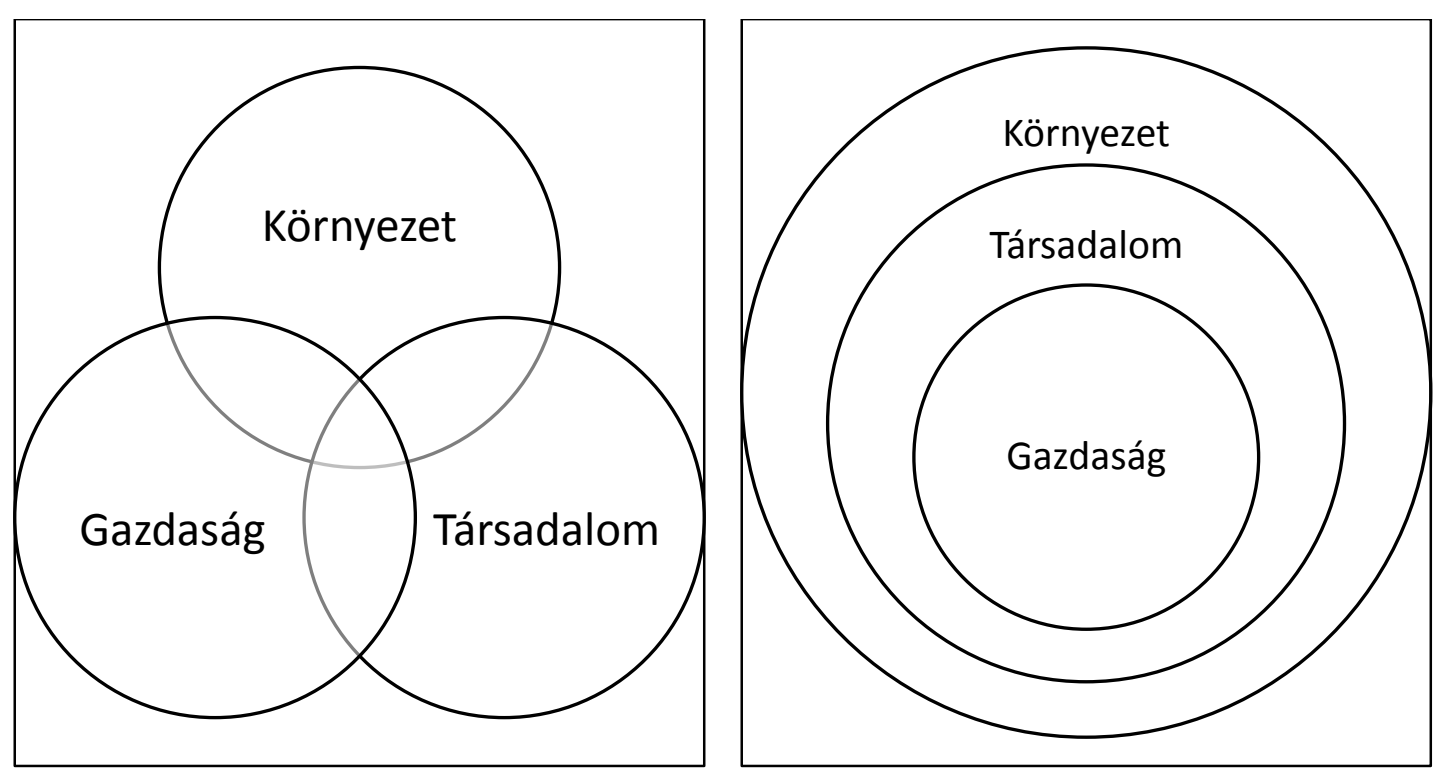

\section{1. ábra: A fenntartható fejlődés pilléreinek a kapcsolódása}

Forrás: saját szerkesztés, Giddings és munkatársai, 2002 alapján

A fenntartható fejlődést több úton lehet segíteni, ilyen irányvonalnak, projektnek tekinthető - a teljesség igénye nélkül - a társadalomért valóban felelős vállalati magatartás kialakítása, a tisztább termelés, a fenntartható építészet, mobilitás, energiagazdálkodás és a fenntartható fogyasztás. A fenntartható fejlődés koncepciójában, a megvalósítás területei között a fenntartható fogyasztás és termelés fontos helyet foglal el. A Riói Nyilatkozat (1992) kiemeli:

„A fenntartható fejlődésnek és minden ember magasabb életszínvonalának az eléréséhez az Államoknak csökkenteniük kell, illetve ki kell küszöbölniük a termelés és a fogyasztás nem fenntartható módjait, és elő kell segíteniük a megfelelő népesedéspolitikát" (Bulla és tsai., 1993, idézi: Valkó, 2003, 6. old.). 
A környezetvédelem intézményesülésének, a fenntartható fejlődés alakulásának főbb állomásait röviden az 1. táblázat foglalja össze.

\begin{tabular}{|c|c|}
\hline Dátum & Esemény \\
\hline 1962 & $\begin{array}{l}\text { Rachel Carson megírta Néma Tavasz címü nagyhatású müvét a felhasznált kémiai } \\
\text { anyagok kedvezőtlen hatásairól. }\end{array}$ \\
\hline $\begin{array}{l}1970 . \\
\text { április } 22\end{array}$ & $\begin{array}{l}\text { Az első Föld Napja rendezvény az Egyesült Államokban, innen eredeztetik a modern } \\
\text { környezetvédő mozgalmak megjelenését. }\end{array}$ \\
\hline 1972 & $\begin{array}{l}\text { A Római Klub létrejötte. } \\
\text { Dennis Meadows és munkatársai megírják A növekedés határai címü jelentést. }\end{array}$ \\
\hline 1970 & $\begin{array}{l}\text { Az UNESCO elfogadta az Ember és bioszféra programot. Célja az emberi tevékenység } \\
\text { és az éghajlati övezetek élővilága közötti kölcsönhatások vizsgálata. }\end{array}$ \\
\hline $\begin{array}{l}1972 . \\
\text { június } 5\end{array}$ & $\begin{array}{l}\text { ENSZ megtartja az Emberi Környezet Világkonferenciáját Stockholmban. } \\
\text { Eredménye: } \\
-\quad \text { Nyilatkozat az emberi környezetröl } \\
-\quad \text { Nyilatkozat az irányelvekröl } \\
-\quad \text { Akcióprogram-javaslatok } \\
-\quad \text { Határozat az UNEP (Egyesült Nemzetek Környezeti Programja) szervezet } \\
\quad \text { felállításáról }\end{array}$ \\
\hline 1984 & $\begin{array}{l}\text { Megalakult az ENSZ Környezet és Fejlödés Világbizottsága. Elnökéül Gro Harlem } \\
\text { Brundtland asszonyt választották. }\end{array}$ \\
\hline 1987 & $\begin{array}{l}\text { A Környezet és Fejlödés Világbizottság jelentése Közös jövönk címmel. Brundtland } \\
\text { jelentésként is ismert. Eredményeként a fenntartható fejlödés fogalma széleskörüen } \\
\text { ismertté vált. }\end{array}$ \\
\hline 1992 & 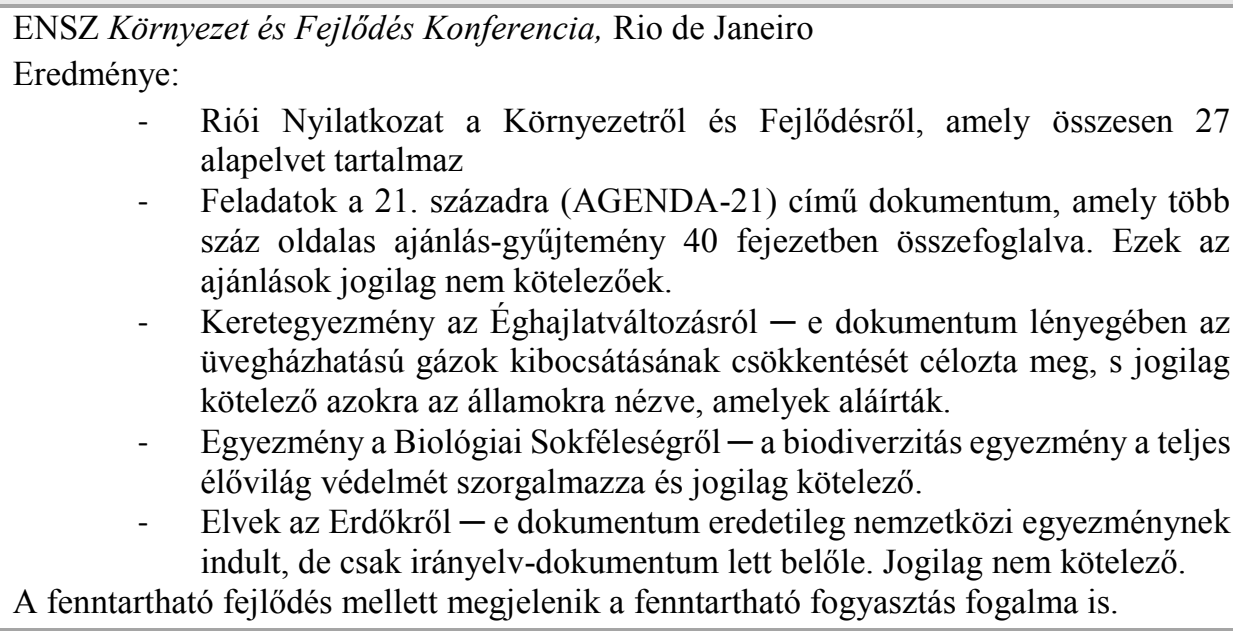 \\
\hline 2002 & $\begin{array}{l}\text { ENSZ Világtalálkozó a Fenntartható Fejlődésről, Johannesburg } \\
\text { Eredménye: } \\
\qquad \quad \text { Johannesburgi Nyilatkozat a fenntartható fejlődésröl, amely } 32 \text { pontot } \\
\quad \text { tartalmaz } \\
\text { - Végrehajtási Terv, amely } 153 \text { pontból áll. } \\
\text { Megjelent a fenntartható fejlödés társadalmi dimenziójának a figyelembevétele, vagyis } \\
\text { a környezetpolitika és a szociálpolitika integrálódása. }\end{array}$ \\
\hline 2012 & $\begin{array}{l}\text { Rio+20 Konferencia } \\
\text { Eredménye: } \\
\text { - } \quad \text { The Future We Want című záródokumentum } \\
\text { - } \quad \text { Vitatott záródokumentum, várt megállapodások, vállalások nem születtek }\end{array}$ \\
\hline
\end{tabular}

1. táblázat: A fenntartható fejlődés koncepció kialakulásának főbb állomásai

Forrás: saját szerkesztés 
A nem fenntartható fejlődés jellemzője a túlfogyasztás és az alulfogyasztás problémája is. A fogyasztás alapvetően pozitív gazdasági hatásokkal jár, addig a pontig, amíg a szükséglet kielégítés nem jár együtt a környezet túlzott kiaknázásával. A fejlett társadalmak túlfogyasztanak, míg a fejlődő országokra, a szegény régiókra az alulfogyasztás jellemző. A fenntartható fogyasztás célja mindkettő megszüntetése, ennek érdekében a fenntartható fogyasztás elősegítése a fenntartható fejlődés elérésében és a környezetpolitikán belül is központi kérdésként kell, hogy megjelenjen (Valkó, 2003).

\subsection{FENNTARTHATÓ FOGYASZTÁS KONCEPCIÓJA}

A Brundtland jelentés ${ }^{3}$ középpontjában a fenntartható termelés kialakításának lehetőségei álltak, a fenntartható fogyasztás nem került a vizsgált területek közé (Tamás, 2006). A fenntartható fogyasztás koncepcióját 1992-ben a Riói Konferencián elkészített AGENDA 21 dokumentum fogalmazta meg először. A fogalom tartalmát a dokumentum definíciószerüen azonban nem határozta meg.

Az első definíciót 1994-ben az oslói miniszteri kerekasztal során formálták meg: „Az alapvető szükségletek kielégítésére és az életminőség javítására irányuló szolgáltatások és termékek használata, miközben a természeti erőforrások és mérgező anyagok használata, ezzel együtt a hulladék és mérgezőanyag kibocsátása minimálisra csökken azzal a céllal, hogy a jövő generációinak szükségleteit ne veszélyeztesse.” (Norvég Környezetvédelmi Minisztérium, 1995, 9 old.)

Eredetileg a fenntartható fogyasztás középpontjába a fenntartható termelést helyezték. Ahogy Hoffmann Istvánné is fogalmaz (2006), először a termelés fenntarthatóságára kell fókuszálni, mert minden termelés az emberi szükséglet kielégítése érdekében zajlik. A lehetséges megvalósítási eszközök kapcsán a termeléshez kötődő ökohatékonyságra, a tisztább termelésre és a megújuló energiaforrások használatára hívta fel a figyelmet az Oslói Nyilatkozat (Vadovics, 2007). A fenntartható fogyasztás koncepciója végeredményben nem a fogyasztás mennyiségének a csökkentéséről szólt, hanem másként fogyasztásról, hatékonyabb fogyasztásról, javított életminőség biztosításáról (UNEP, 2001).

\footnotetext{
${ }^{3}$ Az ENSZ Környezet és Fejlődés Világbizottságának jelentése, 1987
} 
A Riói Csúcs után 10 évvel az ENSZ következő konferenciáját Johannesburgban tartották. A Johannesburgi Nyilatkozatban a Fenntartható fejlödésröl a nemzetek hatáskörébe helyezték a fenntartható fogyasztás és termelés kialakításának a kereteit.

$\mathrm{Az}$ Európai Unió a Johannesburgi Konferenciával elindult Marrakech folyamat ${ }^{4}$ megvalósításában aktív szerepet vállalt (Vadovics, 2007). Az Európai Bizottság meghatározásában a fenntartható fogyasztás és termelés (SCP, Sustainable Consumption and Production) esetében szintén a termelési oldal a hangsúlyosabb. A termékek és szolgáltatások teljes életciklusában kifejtett környezeti terhelését kell figyelembe venni, és adott terméket a környezetet lehető legkevésbé károsító módon előállítani (Európai Bizottság, 2010). A cél az alapvető igények kielégítése, jobb életminőség kialakításával és a jövő nemzedék lehetőségeinek megóvása által.

A fenntartható fogyasztás és termelés tehát kettős fókuszú (Valkó, 2003), szűkebb értelemben a fogyasztott termékek csökkentésére és a fogyasztási szokások megváltoztatására irányul, tágabb értelemben pedig egy új, tartós fogyasztói értékrend kialakítására, amely figyelembe veszi a fenntarthatóság 3 pillérjét (környezet, társadalom, gazdaság).

Ez alapján két lehetséges stratégiai irány vázolható fel (Valkó, 2003):

- hatékonysági stratégia: a termelés környezethatékonyságának a javítását célozza meg, ám ezt a szakmai közvélemény nem tartja elégségesnek.

- helyettesítési stratégia: a fogyasztási struktúra megváltoztatására fókuszál, amelynek része a fogyasztás mértékének csökkentése is.

A fenntartható fogyasztás központi eleme az életminőség. A hangsúly az egyén valamint a társadalmi jólét biztosításán van, fontos kérdés azonban az, hogy mi képviseli igazán a jólétet? Elérhető-e a jólét a javak fogyasztásának csökkentése mellett is? Ha a jóléthez növekvő fogyasztás tartozik, mennyire lehet a környezeti terhelést visszafogni környezethatékony termeléssel? Számos kutatás foglalkozik a visszapattanó hatással ${ }^{5}$, amely gyengíti a fenntartható termelés eredményeit (bővebben lásd Harangozó, 2011).

\footnotetext{
4 A Johannesburgi Konferencián elfogadtak egy Végrehajtási Tervet (Plan of Implementation, UN Commission on Sustainable Development, 2002), amelyben a nem fenntartható fogyasztás és termelés megváltoztatásához szükséges 10 éves keretprogram kidolgozását javasolták, amely a Marrakech Folyamat (Marrakech Process) elnevezést viselte és az ENSZ Környezetvédelmi Programja, a UNEP koordinálta.

5 „A hatékonyság javulásával párhuzamosan adott erőforrás kereslete és felhasználása ceteris paribus megnő, pontosan azért, mert olcsóbbá válik. Ezt a jelenséget visszapattanó hatásnak (rebound effect, takeback effect, snapback effect, backlash effect) nevezzük” (Harangozó, 2011).
} 
A fogyasztás során az emberi kultúra is kifejeződik (WEF, 2011), ami miatt a fogyasztás és az életminőség és jólét kapcsolatát még összetettebben kell vizsgálnunk. Azt már régóta tudjuk, hogy a GDP-vel, a gazdasági jólét növekedésével nem arányosan nő a lakosság jól-lét érzése (Scitovsky, 1990). Ebben a kérdésben a hazai eredmények sem megnyugtatóak (NFFT, 2010), a lakosságnak mindössze 10\%-a vallotta magát nagyon boldognak $^{6}$, míg $40 \%$ csak kicsit vagy egyáltalán nem boldog ${ }^{7}$ értékelést adott (lásd: Melléklet).

A jólét és a fogyasztás kapcsolatának értékelésében az öko-humanisták egészen azon az állásponton vannak, hogy a fogyasztás aktuális mintái az életminőségre károsak, nemcsak azért, mert káros hatásai vannak a környezetre, hanem mert nem megfelelően elégíti ki az egyéni szükségleteket sem. Az embernek nem a piacra van szüksége a boldogsághoz (Kerekes, 2011). „A modern ember elidegenedett önmagától, embertársaitól és a természettől. Átváltozott árucikké, életerőit úgy éli meg, mint befektetést, amelynek az adott piaci feltételek közt elérhető legmagasabb hasznot kell hoznia. Valamennyi ösztönös szükséglet teljes kielégítése nemcsak a boldogsághoz kevés, de még az épelméjüséget sem garantálja” (Fromm, 1993 idézi: Kerekes, 2011, 9. old.).

Ezzel szemben a fogyasztás vizsgálható evolúciós termékként is, tehát a fogyasztói magatartás az emberi fejlődés során kialakult viselkedésmintának tekinthető. Ebből kiindulva a szimbolikus interakcionizmus képviselői a fogyasztás és a materiális javak szimbolikus természetét hangsúlyozzák (Jackson, 2009). Javaink önmagunkról nyújtanak információt, legnyilvánvalóbban a társadalomban betöltött státuszunkról, társadalmi kapcsolatainkról, sőt az érzelmeinkről. A fogyasztás ezáltal segíti a személyes és a társas identitás kialakulását is (Jackson, 2005a). A fogyasztás szerepe és funkciója láthatóan komplex, ezért nem dönthető el a kérdés egyszerüen. A jólétnek vitathatatlanul vannak materiális oldalai, de a jólét követelményei jóval túlmutatnak az anyagi jellegü létfenntartáson, szociális és pszichológiai dimenziói is vannak (Jackson, 2009).

Összefoglalva tehát véleményem szerint a fenntartható fogyasztás kialakításához szükség van a termelési és a fogyasztói oldal megfelelő figyelembevételére. Fontosnak tartom a fenntartható fogyasztás szélesebb koncepciójának hangsúlyozását (lásd Valkó, 2003), amely nemcsak a hatékonyabb termelésre és a fogyasztás visszafogására fókuszál, hanem

\footnotetext{
${ }^{6}$ 6-os vagy 7-es értékelést adott a 7 fokú Likert skálán mérve, ahol 1 - egyáltalán nem boldog; 2 - alig boldog; 3 - egy kicsit boldog; 4 - boldog; 5 - eléggé boldog; 6 - nagyon boldog; 7 - teljesen boldog 7 1, 2, 3-as értékelést adott a 7 fokú Likert skálán mérve
} 
a fogyasztói értékrend és a jólét fogalom átformálására is törekszik. A közösségtől és a természettől való elidegenedés folyamatát vissza kell fordítani a fenntartható illetve a környezettudatos fogyasztás tartós elérése érdekében. A komplex folyamatok, a társadalmi átalakulás elősegítéséhez az érintettek széleskörü bevonása és átgondolt együttmüködése szükséges.

\subsection{A FENNTARTHATÓ FogYASZTÁs ÉRINTETTJEI}

A fenntartható fogyasztás során négy érintett csoportot kell mindenképp kiemelni (lásd 2. ábra); a kormányzat, a vállalatok és a civil szféra szervezeteit, illetve társadalom képviselöit, azaz a polgárok összességét (Sustainable Consumption Roundtable, 2006; WEF, 2011).

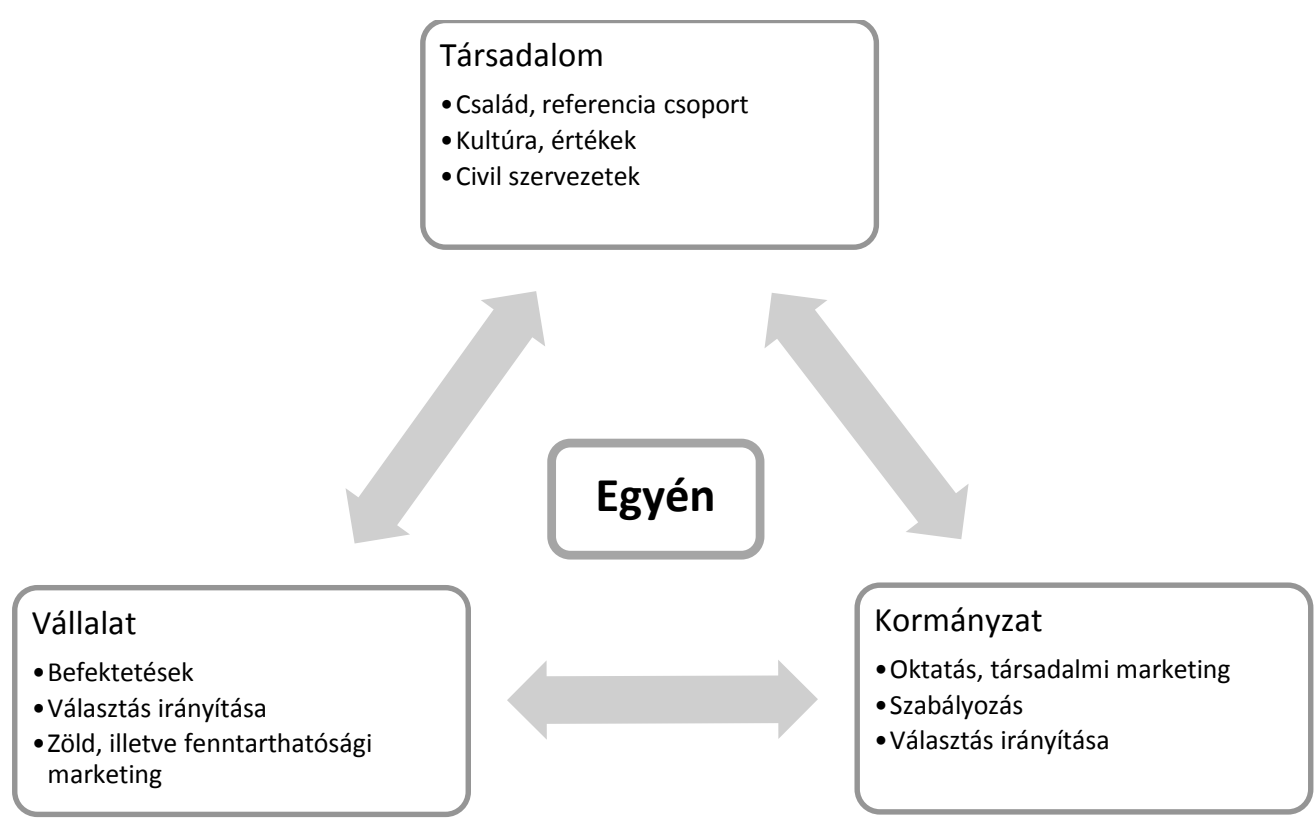

\section{2. ábra: A fenntartható fogyasztás stakeholderei}

Forrás: saját szerkesztés, WEF 2011 és Sustainable Consumption Roundtable, 2006 alapján

A vállalatok a fenntartható fejlődésen alapuló gazdaság építőkövei befektetéseik és fejlesztéseik miatt. A termékfejlesztések során alkalmazott életciklus szemlélet lehetőséget ad az üzleti modellek és értékláncok átalakítására (WEF, 2011). A vállalati érdekek és a környezeti szabályozás is kikényszerítheti az anyag- és energiafogyasztás takarékosságát (NFFT, 2010). A fenntarthatóság szemléletének alkalmazása azt jelenti, hogy a vállalatoknak egyaránt figyelembe kell venni a piac és az erőforrások kapacitását. 
A piac kapacitása az aktuális fogyasztás mértékének a szintjét jelenti, azaz hogy a jövő generációnak lesz-e lehetősége ezt a szintet elérni, míg az erőforrások kapacitása a Föld egyre növekvő lakosságszámából és a szükös erőforrásokból eredő problémát vezeti be (Achrol és Kotler, 2012). A vállalatoknak tehát egyaránt felelőssége alapot biztosítani a felelős fogyasztás megjelenésére a termékek fejlesztése és a megfelelő marketing-mix kialakítása segítségével (Sheth és tsai., 2011), valamint a túlfogyasztás elkerülésének támogatására a fogyasztói tájékoztatás, oktatás segítségével. A vállalatoknak lehetőségük van ráirányítani a fogyasztók figyelmét a fogyasztás társadalmi dimenzióira egy-egy társadalmi marketing kampány támogatásával, fogyasztói oktatással. A közös érték teremtése az értéklánc során szintén a vállalatok felelőssége, a megfelelő termékportfólió kialakításával a fogyasztók választása is irányítható, ha a fenntarthatósági szempontoknak megfelelő termékek kerülnek túlsúlyba a piacon (WEF, 2011).

A kormányzat a fenntartható fogyasztás szabályozási keretének meghatározásával alapozza meg a fenntartható fogyasztás kialakulását. A közpolitikai irányelvek hajtják a piacokat és irányítják az érintetteket a cselekvések mérlegelésére (WEF, 2011). A kormány feladata a makrogazdasági stabilitás fenntartása, amely jelen világban a folyamatos növekedésen alapul. Ezzel ellentmondásban a kormány felelőssége a hosszú távú célok elérésének megteremtése is, a társadalmi és ökológiai javak hosszú távú védelme. A kormány részt vesz a fogyasztás kultúrájának müködésében, alakíthatja is annak szerkezetét, befolyásolva ezzel az emberek viselkedését (Jackson, 2009). A kormány az oktatással, a piacok szabályozásával és a közérdek irányelveinek meghatározásával olyan közeget alakíthat ki, ahol a fenntarthatóság iránti fogyasztói döntések megfelelő támogatást kapnak.

A társadalomban élő polgárok, fogyasztók a fenntartható fogyasztás müködésének kulcsszereplői. Nem csak azért, mert termékválasztásukkal hatással vannak a környezetre, hanem azért is, mert a közösség tagjai, globális állampolgárok. A közösség szerepe, egyéni viselkedésre gyakorolt hatása pedig elvitathatatlan. A túlfogyasztás jelenlegi társadalmilag elfogadott normája helyett új normát kell kialakítani, amely a nyújtott értékeken és nem a tulajdonlás fontosságán alapul (Valkó, 2003). A fenntartható fogyasztás iránt elkötelezett fogyasztók aránya azonban még túl alacsony ahhoz, hogy a gazdaságot a jó irányba mozgassa, de támogató hatásuk már megjelenik. A fogyasztók elkötelezése a fenntarthatóság iránt emiatt a többi érintett felelőssége is (WEF, 2011). A vásárlási döntés során a fogyasztók választását általában a vásárlás helyszínén próbálják 
megváltoztatni. A tartós elköteleződéshez azonban a fogyasztói értékek megváltoztatása is szükséges, amely lassú folyamat. Az értékek megváltozásával a fogyasztók a tágabb közösségükkel kell, hogy azonosuljanak. A minél szélesebb társas közösséggel - akár a természettel magával - való identifikáció elősegíti a fogyasztói magatartásra gyakorolt erősebb hatást is. Az elköteleződéshez az „Én” -ből a „Mi” közösségévé kell válnia a fogyasztóknak (Doppelt, 2012).

A következö alfejezetekben célom a már elkötelezett, a környezettudatos fogyasztó bemutatása és a környezettudatos fogyasztói magatartás megvalósulási formáinak értelmezése.

\subsection{KÖRNYEZETTUDATOS FOGYASZTÓ JELLEMZÖI ${ }^{8}$}

A környezettudatos fogyasztó meghatározására számos definíció áll rendelkezésünkre. Roberts (1996) szerint az a fogyasztó tekinthető környezettudatosnak, aki olyan termékeket és szolgáltatásokat vásárol, amelyekről feltételezi, hogy pozitív vagy kevésbé negatív hatásuk van a környezetre. Meffert és Kirchgeorg (1993) meghatározása szerint a környezettudatos fogyasztók olyan természetes vagy jogi személyek, akik az ökológiai hatásokat figyelembe véve hozzák meg vásárlási döntéseiket. Az ökológiailag tudatos fogyasztó felismeri, hogy egy termék kifejlesztése, előállítása, disztribúciója, fogyasztása és használata, sőt az azt követő szakasz is környezetet terhelő hatásokkal jár, és többletköltségeket okoz. A fogyasztó ezeknek a negatív hatásoknak és az okozott többletköltségeknek a minimalizálására törekszik (Meffert és Kirchgeorg, 1993).

A környezettudatos magatartást végző fogyasztókat a kutatások általában demográfiai jellemzőkkel igyekeznek leírni, hiszen a demográfiai változók alapján egyszerübb a szegmensek beazonosítása (Straughan és Roberts, 1999). Ez alapján a tipikus környezettudatos fogyasztó a fiatal felnőtt, közepes illetve magas jövedelemmel és magas iskolai végzettséggel rendelkező, városi nő. A hazai kutatások eredményei is hasonló képet mutatnak, a fiatal, iskolázott, budapesti nők számára kiemelten fontos probléma a környezetvédelem kérdése (Csurgó, 2002; Hofmeister-Tóth és tsai., 2012b).

A demográfiai jellemzők közül a kor, a foglalkoztatottság, a nem és a környezettudatosság között találtak a kutatások jellemzően szignifikáns kapcsolatot. A

\footnotetext{
${ }^{8}$ A fejezet részletei megjelentek cikk formájában (Hofmeister-Tóth és tsai., 2012b)
} 
nők általában jobban aggódnak a környezetért és pozitívabb az attitüdjük a környezet iránt (Anderson és Cunningham, 1972; Davidson és Freudenburg, 1996; Roberts, 1996). Kor alapján a leginkább elfogadott, hogy a fiatalok jobban aggódnak a környezetért (Diamantopoulos és tsai., 2003). A demográfiai jellemzők közül a végzettség esetében kevés ellentmondás figyelhető meg. Az eredmények (Anderson és Cunningham, 1972; Roberts, 1996; Schwartz és Miller, 1991) pozitív kapcsolatot mutattak ki a végzettség és a környezettudatosság aspektusai, azaz a környezeti tudás, az attitűd és a viselkedés (Diamantopoulos és tsai., 2003) között egyaránt.

Korábbi hazai kutatások a nem alapján nem találtak jelentősebb eltérést a vizsgált szempontok, a környezeti problémák iránti érzékenység, a környezeti témákban való informáltság, illetve a környezetbarát termékek használata mentén (Valkó, 2003). Saját eredményeink azonban azt mutatják, hogy a környezetbarát viselkedések gyakoriságát vizsgálva a nők általában - nem minden cselekvéstípusnál volt megfigyelhető szignifikáns különbség - több környezettudatos viselkedést végeztek, mint a férfiak, 2010-ben és 2012-ben is (Hofmeister-Tóth és tsai., 2012a; Hofmeister-Tóth és tsai., 2012b). A kor hatásának vizsgálata során a hazai minta eltér az általános nyugati mintától. A magyar fiatalok alacsonyabb fokú érdeklődést mutatnak a környezetvédelem témái iránti, valamint kevesebb környezetbarát viselkedést gyakorolnak aktívan, mint a középkorú, illetve az idősebb válaszadók. A középkorúak tekinthetőek a legaktívabbnak a környezetbarát cselekvések végzése esetén (Hofmeister-Tóth és tsai., 2012b, Hofmeister-Tóth és tsai., 2012a, Valkó, 2003). A végzettség esetében a hazai kutatások (Csurgó, 2002; Hofmeister-Tóth és tsai., 2012b; Valkó, 2003) eredményei is a magasabb végzettséghez környezettudatosabb viselkedést mutattak ki.

Második kutatási irányként megjelentek a pszichográfiai és társadalmi tényezőket vizsgáló kutatások, amelyek a környezettudatos viselkedés előrejelzésére erősebb tényezőknek bizonyultak (Straughan és Roberts, 1999). A leggyakrabban vizsgált koncepciók között a környezeti tudás, a környezeti attitüd, az értékorientáció, környezeti aggodalom és az észlelet fogyasztói hatékonyság áll (Laroche és tsai., 2001; Leonidou és tsai., 2010). Az említett változókat számos kutatás (Bamberg és Möser, 2007; Banerjee és McKeage, 1994; De Groot és Steg, 2008; Dunlap és tsai., 2000; Moisander, 2007; Schultz, 2001; Zsóka és tsai., 2013) kapcsolta össze a környezetbarát viselkedéssel, és talált általában közepes erősségü, de kutatásonként eltérő erősségü kapcsolatot. 
Az észlelt fogyasztói hatékonyság az egyén azon ítélete, hogy fogyasztásával mennyire képes a környezeti problémák befolyásolására (Antil, 1978 idézi: Roberts, 1996). A kutatások (Ellen és tsai., 1991; Straughan és Roberts, 1999; Webster, 1975) az észlelt fogyasztói hatékonyságot a környezettudatos viselkedés egyik legerősebb meghatározójának találták.

A környezeti aggodalom hatását szintén érdemes figyelembe venni, mert minél vonzóbb a környezet, annál jobban aggódunk érte és ez annál altruisztikusabb tettekre sarkallja az embert (Roberts, 1996). A környezeti aggodalom hatása azonban gyengébbnek tünik, mint az észlelt fogyasztói hatékonyság hatása. A környezeti aggodalom, ha nem párosul a hatékonyság érzésével, kevésbé valószínü, hogy cselekvésre sarkallja a fogyasztókat.

A környezeti attitüd egy személy hiedelmeként, érzelmeként és cselekvési szándékaként definiálható a környezettel kapcsolatos kérdések esetében (Schultz és tsai., 2004). Az attitüd a fogyasztói magatartás kutatások alapján azonban egyedül nem elég a valós viselkedés előrejelzéséhez (Diamantopoulos és tsai., 2003). A pozitív attitüd és az attitüdváltozás az egyszerü, ismétlődő, alacsony költségű tevékenységek esetében hatásos, míg a hosszú távú elkötelezettséget igénylő választásoknál és a magasabb költséget igénylő cselekvéseknél a pozitív attitüd nem tükröződik vissza a cselekvésekben (Gatersleben és tsai., 2002). A pszichográfiai változók csoportját az elmúlt években a személyiség szerepének a vizsgálatával egészítették ki (Bartels és Hoogendam, 2011; Brügger és tsai., 2011; Doherty, 2009; Dono és tsai., 2010; Hinds és Sparks, 2008; Hirsh, 2010; Sparks és Guthrie, 1998; Whitmarsh és O'Neill, 2010).

A demográfiai jellemzőkön alapuló meghatározásoknak a könnyen kezelhetőség az előnye, de a pszichológiai változók erősebb, és így hasznosabb jellemzési lehetőséget jelentenek a környezetbarát fogyasztók bemutatására (Straughan és Roberts, 1999). Annak ellenére, hogy a demográfiai jellemzők és a környezettudatos cselekvések között találtak szignifikáns kapcsolatot, e változók magyarázóereje gyengébb, mint a pszichográfiai változóké. A bemutatott kutatások ellentmondásos eredményei is mutatják, hogy a demográfiai változók vizsgálata szükséges, de nem elégséges. A környezettudatos magatartásformák melletti tartós elköteleződés érdekében a fogyasztói gondolkodásmódot kell átalakítani, amely a pszichográfiai tényezőkön alapul.

A környezettudatos fogyasztó vizsgálatához szükséges a környezettudatos viselkedés pontos értelmezése is. Környezetbarát viselkedésnek tekintjük általában azokat a viselkedésformákat, amelyek célja, hogy az egyén tevékenységeinek a környezetre 
gyakorolt negatív hatásait minimalizálja (Kollmuss és Agyeman, 2002). Ez a definíció összhangban van Meffert és Kirchgeorg már bemutatott, környezettudatos fogyasztó definíciójával. Ebben a meghatározásban a környezetbarát viselkedés cél vezérelt, az egyének azért végzik, hogy a környezettel jót cselekedjenek. Mivel a cselekvési szándék és a valós viselkedés között logikai kapcsolat van, Kaiser és Wilson (2004) azt javasolja, hogy kizárólag ezeket a célorientált viselkedéseket tekintsük környezetbarát viselkedésnek.

Második megközelítésben Steg és Vlek (2009) azokat a tevékenységeket tekinti környezetbarátnak, amelyek a lehető legkevésbé károsítják a környezetet, vagy akár jótékony hatással vannak rá (Steg és Vlek, 2009). Ebben a megfogalmazásban azok a tevékenységek is környezetbarátnak tekinthetőek, amelyeket nem feltétlenül környezetvédő motivációk irányítanak. Így azok a tevékenységek is környezetbarátnak számítanak, amelyeket egyéb, például anyagi vagy egészségi okokból végeznek az egyének, vagy akár megszokásból.

Fontos azonban megjegyeznünk, hogy a környezetbarát viselkedés nem feltétlenül jár valós hatással, még akkor sem, ha környezetbarát célok mentén szerveződik (részletesebben lásd Csutora, 2012). Tovább árnyalható ezáltal a környezetbarát fogyasztó képe, ki tekinthető annak, aki minél több környezetbarát tevékenységet végez, vagy akinek a valós környezeti hatása jobb? A szakirodalom mind a két megközelítést egyaránt alkalmazza, a kutatási céloktól függően. Disszertációmban Kaiser és Wilson skáláját alkalmazom és az általuk javasolt szükebb tevékenység koncepciót fogadom el.

A környezetbarát tevékenységek számos formában jelenhetnek meg, mint például a környezetbarát termékek vásárlása, vagy az energiatakarékosság, szelektív hulladékgyüjtés, de ide sorolható a politikai aktivitás is egy adott ügy érdekében. Láthatóan széles skálát fog át a lehetséges tevékenységek köre, amelynek eltérö csoportosításai lehetnek.

Meffert és Kirchgeorg (1993) például a környezettudatos viselkedés öt típusát határozta meg, amelyből a legtöbb fogyasztó egy-két tényezőt választ ki, a lehetőségek teljes körét nem használja. Az öt viselkedésmód a következő (Meffert és Kirchgeorg, 1993):

1) hagyományos termékek fogyasztásának csökkentése,

2) keresletmódosítás, azaz környezetbarát termékek vásárlása,

3) környezet-hatékony termékek fogyasztása,

4) részvétel az újrahasznosításban, szelektív hulladékgyüjtésben,

5) környezettudatos panasz illetve tiltakozás. 
A tevékenységek közötti jelentős különbségek miatt a szakirodalom jellemzően több dimenziósnak tekinti a környezetbarát tevékenységeket. Az eltérő cselekvési lehetőségek között nem sikerült bizonyítani a tovagyürüző hatást, aki egy területen környezettudatosan viselkedik nem feltétlenül kezd el más területeken is elköteleződni a környezet iránt (Thøgersen és Ölander, 2003). A kutatások emiatt egy-egy specifikus cselekvést emelnek ki, azért is, mert az eltérő viselkedés típusok eltérő motivációs háttérrel rendelkeznek (McKenzie-Mohr és tsai., 1995). Egy-egy specifikus viselkedésformára való fókuszálás azonban azt is jelenti, hogy nem alakul ki egy integrált elmélet a környezetvédelem területén.

Ezzel szemben Kaiser és Wilson (2004) az egydimenziós koncepciót javasolják, amely a környezettudatos viselkedések között a viselkedés megvalósításának a nehézsége alapján tesz különbséget és nem az irányító motiváció alapján. Azt feltételezik, hogy a tevékenységeket a költséghatékonyság irányítja így azok a tevékenységek, amelyeket a legtöbb egyén végez, a könnyü tevékenységek, míg a kevés egyén által végzett tevékenységek a nehéz tevékenységek, amelyeknek a végzéséhez erős környezetbarát attitüd szükséges. A Kaiser és Wilson által támogatott koncepció az attitüd és a környezetbarát viselkedés között erős kapcsolatot feltételez (Gatersleben, 2012).

A fenti bemutatás alapján látható, hogy a környezetbarát fogyasztó és a környezetbarát viselkedés vizsgálata során értékes eredmények várhatók a pszichográfiai tényezők (pl. érték, attitűd, személyiség) vizsgálatából. A további szakirodalmi szintetizálás és a kutatási elemzés során ezekre a tényezőkre fókuszálok. 


\section{A PSZICHOLÓGIA IRÁNYZATAINAK ÉRTELMEZÉSE A KÖRNYEZETTUDATOS VISELKEDÉS VIZSGÁLATÁBAN}

A disszertációm kiemeli a pszichológia eredményeinek a fogyasztói magatartás területén való alkalmazási lehetőségeit és összekapcsolja a két területet a környezetbarát fogyasztói viselkedés vizsgálata során. A pszichológia tudomány a marketing számos aspektusára hatással volt és van, de a fogyasztói magatartás területén a két területnek a mély kötődése vitathatatlan. Gondoljunk azokra a jól ismert fogalmakra, mint a motiváció, attitűd, észlelés, meggyőzés, amelyek mind-mind a pszichológia tudományban gyökereznek, de a fogyasztói viselkedés, a marketing tevékenységek sikerének megértéséhez is nélkülözhetetlenek.

A 2.3 fejezetben bemutatott környezetbarát viselkedésformák értelmezhetőek a termék vagy szolgáltatás igénybevételének döntési helyzeteként. Ez alapján a vásárlói magatartás modelljeinek összefüggései és a vásárlói döntési folyamat lépései értelmezhetőek a környezetbarát tevékenységek vizsgálatára is. Ezek a modellek (lásd például Engel Blackwell - Miniard - modell, 1990) komplexitásukban eltérőek, de alapvetően az alábbi elemeket tartalmazzák:

- döntési folyamatot befolyásoló változók: itt lehet megemlíteni az egyéni tényezőket (motiváció, értékek, életstílus, személyiség) és a társadalmi tényezőket (kultúra, csoport, család), amelyek megértéséhez a pszichológia több irányzata is hozzájárult, mint például pszichoanalízis az irracionális döntések és a tudattalan bevezetésével, illetve a szociálpszichológia a társas kapcsolatok vizsgálatával.

- információ feldolgozás: hatással van az észlelés, figyelem, megértés, emlékezés, tanulás, amelyek vizsgálatában a gestalt pszichológia, illetve alaklélektan (például érzékelésre és észlelésre vonatkozó kutatásai), valamint a kognitív pszichológia (például információ feldolgozásra, emlékezésre) vonatkozó eredményeit érdemes kiemelni.

- döntési folyamat: általában öt lépést vizsgál (1) probléma-felismerés, (2) keresés, (3) alternatívák értékelése, (4) vásárlás, (5) végeredmény. Ezeknek a szakaszoknak a vizsgálatánál mind az egyéni belső tényezők, mind a társas hatás 
befolyása fontos elemzési keret, ezért a kognitív pszichológia és a szociálpszichológia eredményei egyaránt alapot adnak.

A disszertációmban vizsgált pszichográfiai tényezők a szociálpszichológiában gyökereznek, ezért a fejezetben a szociálpszichológia személyiség értelmezését és a környezettudatossághoz kötődő releváns tényezőket mutatom be részletesen. A fejezet lezárásaként az ökopszichológia alapjait vázolom, mert a környezeti identitás értelmezése az 5. fejezetben az ökopszichológia kereteiben valósul meg.

\subsection{SZOCIÁLPSZICHOLÓGIAI PERSPEKTÍVA}

A marketing leggyakrabban a szociálpszichológia eredményeire alapozza kutatásait. Ez a perspektíva a környezetbarát viselkedés kialakulásának és támogatásának vizsgálatában is kiindulási alapot és segítséget nyújt. A környezetre hatással lévő tevékenység alapvetően nem elszigetelt egyéni tevékenységet jelent, hanem jelentősen befolyásolja a társadalmi hatás (Koger és Scott, 2007).

A környezeti fenntarthatóságot vizsgáló kutatások jellemzően az attitüd (Cook és tsai., 2002; Grob, 1995; Kaiser és tsai., 2010; Kellert, 1993; Rauwald és Moore, 2002), a meggyőzés (Davis, 1995; Gonzales és tsai., 1988), az elkötelezettség (Davis és tsai., 2009; Davis és tsai., 2011; Hinds és Sparks, 2008; Werner és tsai., 1995), a normatív befolyásolás (Aronson és O’Leary, 1982; Cialdini és tsai., 1990), és az ösztönzés (Levitt és Leventhal, 1986; Stern és tsai., 1985) kérdéseit vizsgálják.

A korai kutatások egy-egy jellemző helyi környezeti problémát dolgoztak fel, mint pl. az otthoni energiahasználat vagy hulladékkezelés, míg napjainkban a kutatások a specifikus szemléletből elmozdultak a tágabb, a természet és egyén kapcsolatát újraértelmező témák irányába (Mayer és Frantz, 2004), mint a kulturális értékek (Banerjee és McKeage, 1994; Dutcher és tsai., 2007; Schultz és tsai., 2005; Schultz és Zelezny, 1999; Schwartz, 1999; Stern és Dietz, 1994; Stern és tsai., 1999), a környezeti aggodalom (Hirsh, 2010; Schuett és Ostergren, 2003; Schultz, 2001; Schultz és tsai., 2005), és a természet által befolyásolt identitás szerepe (Clayton, 2003). Az alábbiakban röviden bemutatom a főbb kérdésköröket és fogalmakat annak érdekében, hogy a környezeti identitás modellbe helyezésében támpontot nyújtsanak. 


\subsubsection{A SZOCIÁLPSZICHOLÓGIA ÉN-FOGALMA}

A szociálpszichológia fókuszában az egymással való interakció, társas hatások és társas viselkedések vizsgálata áll. Az én-fogalom vizsgálata során fő kérdés, hogy a személy hogyan alakíthat ki a társas közegben egy koherens én-fogalmat. Az én-fogalomra a személyes tapasztalatok, másokkal való interakciók, kulturális hatások egyaránt hatással vannak. Az én-fogalom a személyes élmények stabil és rendezett struktúrájából áll. Így az én egy tárgy, amely bennünk van, mindannak az összessége, ami „én” vagyok (Bordens és Horowitz, 2008).

Az én-fogalom tehát az egyén önmagáról, mint tárgyról alkotott gondolatainak és érzéseinek az összessége. Mint egy tárgy, az egyénnek arra van szüksége, hogy kilépjen és külső szemlélőként figyelje meg önmagát (Owens és Samblanet, 2013)

Szociálpszichológiai megközelítésben az én-fogalom három forrásból származhat (Bordens és Horowitz, 2008) (1) a visszatükröző megítélésből (2) társas összehasonlításból és (3) introspekcióból.

- Visszatükröző megitélés: a másoktól önmagunkra kapott visszajelzéseket jelenti (Cooley, 1902, idézi Bordens és Horowitz, 2008). Ez a szimbolikus interakcionizmus központi eleme, azt bizonyítva, hogy az én társas termék, amely abból fakad, hogy mások hogyan reagálnak az egyénre. Ez az alapja Mead én elméletének és Cooley tükör én koncepciójának.

- Társas összehasonlítás: az a folyamat, amikor a saját reakcióinkat, képességeinket és jellemzőinket a társas közegünkkel hasonlítjuk össze (Festinger, 1954). Az összehasonlítás célja, hogy pontosabb információkat szerezzünk és megpróbáljuk kiszámíthatóbbá tenni az életet. Két szemponton alapulhat az összehasonlítás, kritérium alapon, amikor adott szempont alapján jobbnak, vagy rosszabbnak ítéljük meg önmagunkat, illetve normatív szempont alapján, amikor eltérés vagy konformitás, másokkal való harmónia alapján hasonlítjuk össze (Owens és Samblanet, 2013).

- Introspekció: önmagunk viselkedésének a belső megfigyelése. Ez alapvetően azért fontos, mert gyakran nem tudjuk viselkedésünket indokolni, és a motiváció és a viselkedés közötti feltételezett következetes kapcsolat alapján a viselkedésünkből következtetünk vissza a motivációra.

Ezt a három alapelvet egészíti ki a lélektani központiság elvével Owen és Samblanet (2013). A koncepció szerint az én hierarchikusan szerveződő, összefüggő egységekből 
áll. Ezek az egységek olyan jellemzőkből és identitásokból állnak, amelyek a személy számára fontosak. A részek funkciója, hogy az egyén én-fogalmát védje azáltal, hogy adott szituációban a potenciálisan veszélyes én-jellemzőket a perifériára, míg az én erősítő jellemzőket és identitásokat a központba helyezi.

$\mathrm{Az}$ én-fogalom ebben a paradigmában tehát saját magunkra vonatkozó ötleteinkből, meggyőződéseinkből és személyes jellemzőinkből (például: nő, anya, katolikus, művészi hajlamú, stb.) áll. Ezeket a jellemzőket vizsgálva leggyakrabban említettek azok, amelyek egyedivé, megkülönböztetővé teszik az egyént. Emellett ha az egyén egy kisebb, nem domináns csoport tagja, a csoportot megkülönböztető jellemzők is erősen az én-fogalom részévé válnak (McGuire és McGuire, 1988). Az én-fogalom elmélet értelmében az egyének a megfigyeléseik, értékeléseik alapján következtetéseket vonnak le az énükről. Az egyén célja, hogy óvja és fenntartsa az aktuális én-fogalmát (Owens és Samblanet, 2013). Az én-fogalomnak három szempontból van jelentősége (Swann és tsai., 2007):

- irányítja az egyén viselkedését

- lehetővé teszi, hogy előre jelezze más egyének reakcióját a saját viselkedésre

- segít rendszerezni az egyén valóságról alkotott nézetét.

Az én-fogalom a szociálpszichológiában közel áll a szociológiai szemlélethez, mert az ént és a társadalmat iker-születésűnek tekintették már Cooley és Mead szimbolikus interakcionizmus elméletében is. Az én-fogalom tehát mint társas termék a társas interakciókból alakul ki és számos társadalmi faktor formálja, mint az egyén társas pozíciója, kulturális és társadalmi struktúrában való elhelyezkedése.

Az én-fogalom emellett társas befolyás is, mert jelentős következményei vannak mind az egyén viselkedésére, mind a csoport viselkedésére (Owens és Samblanet, 2013). Az énfogalom hatással van az egyén gondolataira, érzelmeire és viselkedésére. Másodsorban formálja a csoportot is, amelynek az egyén a tagja, illetve a társadalmat a társadalmi problémák megnyilvánulásán keresztül. Így az én-fogalom mint termék és mint befolyásoló erő is megjelenik a személy életében.

\subsubsection{A SZOCIÁLPSZICHOLÓGIA ALKALMAZÁSA A KÖRNYEZETBARÁT TEVÉKENYSÉGEK MEGÉRTÉSÉRE}

A fogyasztói magatartás kutatásban a viselkedést befolyásoló személyes tényezők vizsgálata kiemelt fontosságú. A fogyasztói magatartás modellek és a környezetbarát viselkedés vizsgálatára is használt modellek a szociálpszichológiában gyökereznek, ezért 
jelen alfejezetben a fogalmak részletes bemutatására törekszem annak érdekében, hogy az empirikus kutatás során adaptáljam a fogalmakat.

\section{ÉRTÉK}

$\mathrm{Az}$ értékeket fontos életcélokként vagy alapelvekként lehet felfogni (Olson és Zanna, 1993; Rokeach, 1973). Az értékek rendező elvként müködnek az attitüdök és a hiedelmek esetében, és az attitüdöt meghatározó tényezőként tekinthetünk rájuk.

A fogyasztás szempontjából fontos értékeket a szükebb és tágabb kulturális környezet határozza meg. A kulturális értékek “a társas környezet által elfogadott meggyőződések arról, hogy mi helyes és kívánatos” (Székely, 2003, 285. old.). Az értékek jellemzője, hogy tartósak, valamint irányítják az események értékelését. Az értékek elvontak, nem konkrét tárgyra irányulnak (Hofmeister-Tóth és Törőcsik, 1996), így szituáció felettiek. Az értékek akkor is megmaradnak, ha az azt megvalósító célok már teljesültek (Schwartz, 2007). Az értékek fő jellemzői az alábbiak (Groot és Steg, 2010):

- meggyőződéseken alapulnak;

- absztraktak;

- cselekvések során vezérelvként müködnek, az emberek és események értékelése és választása esetén hatással vannak a döntésünkre;

- hierarchikus rendszerbe rendeződnek.

Az értékek kutatásának hasznossága azzal indokolható, hogy erős szerepük van a meggyőződések és a viselkedésformák magyarázatában, valamint hasznosak az attitűd és a viselkedési szándék elörejelzésére (Kamakura és Novak, 1992; Stern, 2000). Az egyének relatíve kevés számú értéket vesznek figyelembe, ezért hasznos magyarázó tényezők lehetnek az egyének, kultúrák, nemzetek, csoportok közti különbségek értelmezésében (Groot és Steg, 2010).

Az értékek és a környezetbarát magatartás kapcsolatának vizsgálata során az értékrendet általánosan és a környezetre fókuszáltan is érdemes vizsgálni. Az általános értékrend a szocializáció során beépül az egyénbe és meghatározza attitüdjeit, normáit és a viselkedését is. A környezeti érték fogalma alatt azokat az értékeket értjük, amelyek a természethez köthetőek, vagy meghatározott környezeti attitűddel vagy aggodalommal korrelálnak (Schultz és tsai., 2004). A környezetbaráti értékek hatást gyakorolnak a környezetbarát magatartás kialakulására, míg az általános értékekből csak meghatározott értékek állnak kapcsolatban a környezetbarát értékekkel. Az értékek és a viselkedés kapcsolatát már megbízhatóan igazolták (Thøgersen és Ölander, 2002), meghatározott 
értékek aktiválása befolyásolhatja a környezetbarát viselkedések specifikus meggyőződéseit, normát, viselkedési szándékot és viselkedést (Thøgersen és Ölander, 2006).

\section{Általános értékrend vizsgálatok}

A Rokeach-féle értékskála bemutatása

A marketingkutatás korai szakaszában az értékrendet leggyakrabban a Rokeach értékekkel vizsgálták (Székely, 2003). A Rokeach - skála 18 cél- és 18 eszközérték rangsorolásából áll. Az eszközértékek a kedvező cselekvési módokat, míg a célértékek a végállapotokat határozzák meg, amelyek tartósan fennmaradó nézeteket fogalmaznak meg (Neulinger, 2001). Az értékek egy része én-központú érték (pl.: önbecsülés), néhány pedig társadalom-központú (pl.: világbéke) (Beatty és tsai., 1985).

A skála kritikái között megjelenik, hogy túl általános, történelmietlen és elvont, mivel az egyéni értékek konkrétabb dolgokhoz kapcsolódnak, nem pedig az átfogó értékekhez (Füstös és Szalma, 2010). További kritika érte a skálát a nehéz kitölthetősége miatt, mivel 18-18 értéket rangsorba rendezni nehéz, és időigényes feladat, valamint a társadalmi megfelelési kényszer is felmerülhet (Beatty és tsai., 1985).

Közvetlenül nem jelenik meg a környezetvédelem az értékek között, de a célértékek között megtalálható a „,világ szépsége” és a „kényelmes élet”. Simmons, Binney és Dodd (1992) hozzáadták a „tiszta környezet” értéket a skálához, és azt találták, hogy nem tekinthető önálló értéknek (Simmons és tsai., 1992).

\section{List of Value értékskála}

Az értékek vizsgálatának elterjedt módszere a LOV értéklista. Ezt a listát a Michigani Egyetem kutatói fejlesztették ki, Feather, Maslow és Rokeach munkásságára alapozva. A lista eredetileg 9 értékből állt (valahová tartozás, jó kapcsolat másokkal, önmegvalósítás, elismertség, szórakozás és az élet élvezete, biztonság, önbecsülés, az alkotás érzése, izgalom), amelyből később Kahle az izgalom érték alacsony megjelenési gyakorisága miatt a szórakozás és az élet élvezete értékkel összevonva, 8-as listát alkalmazott kutatásai során. Az értékek Maslow motivációs hierarchiájában is elhelyezhetőek, és az élet főbb szerepeihez is jól kapcsolhatók (házasság, munka, szabadidő). A válaszadóknak vagy a számukra két legfontosabb értéket kell kiválasztaniuk, vagy rangsorba kell állítaniuk az értékeket (Kahle és tsai., 1986). 
A LOV értékek én-központúak (Beatty és tsai., 1985), amit a szerzők azért hangsúlyoznak, mert az én-fókuszú értékeknek több élethelyzetben és szerepben van relevanciája, mint a társadalom-központú értékeknek. Emiatt a fogyasztáskutatásban is jobban alkalmazható, mert a fogyasztói döntések is általában egyéni célokhoz köthetőek és nem társadalmiakhoz.

\begin{tabular}{|l|l|}
\hline LOV & Rokeach \\
\hline $\begin{array}{l}\text { Szórakozás és az élet élvezete (Fun and } \\
\text { enjoyment) }\end{array}$ & Élvezet (Pleasure) \\
\hline Izgalom (Excitement) & Izgalmas élet (Exciting life) \\
\hline Jó kapcsolat másokkal (Warm Relationship) & Igaz barátság (True friendship) \\
\hline Önmegvalósítás (Self- fulfillment) & Belső harmónia (Inner harmony) \\
\hline Elismertség (Being well-respected) & Társadalmi elismerés (Social recognition) \\
\hline Az alkotás érzése (Sense of accomplishment) & Az alkotás érzése (Sense of accomplishment) \\
\hline Biztonság (Security) & $\begin{array}{l}\text { Családi biztonság (Family security, National } \\
\text { security) }\end{array}$ \\
\hline Önbecsülés (Self-respect) & Önbecsülés (Self-respect) \\
\hline Valahova tartozás érzése (Sense of belonging) & \\
\hline
\end{tabular}

2. táblázat: Az eredeti LOV és Rokeach értékskála összehasonlítása

Forrás: saját szerkesztés, Beatty és mtsai, 1985 alapján

Az értékek között különbséget lehet tenni az alapján is, hogy külső vagy belső irányítottságúak ${ }^{9}$. A külső értékek közé sorolható a valahova tartozás érzése, az elismertség és a biztonság. A belső értékek közé tartozik az összes többi (Kahle és tsai., 1986). Az értékek beteljesülhetnek személyes kapcsolatok által (valahová tartozás, jó kapcsolat másokkal), egyéni faktorok által (önbecsülés, elismertség, önmegvalósítás) vagy személytelen tényezők által (az alkotás érzése, biztonság, izgalom, szórakozás és az élet élvezete).

A LOV és a Rokeach értékek között vannak megegyező, illetve hasonló fogalmat jelképező értékek (lásd: 2. táblázat). A Rokeach-skálával összehasonlítva a LOV skála elönye, hogy könnyebben alkalmazható, a válaszadóknak könnyebb kitölteni, valamint az értékek jobban köthetők a fogyasztói magatartáshoz, vásárlási szokásokhoz (Beatty és tsai., 1985).

\footnotetext{
${ }^{9}$ Belső kontrollról beszélünk, ha a megerősítés elérése föleg saját képességeinken vagy készségeinken múlik, míg külső kontrollról, ha ha ez külső körülmények vagy a szerencse hatására történik (Fröhlich, 1996).
} 


\section{A Schwartz-féle értékek bemutatása}

Schwartz értékskálája a fent bemutatott Rokeach értékskálán és a Kahle-féle List of Value értékmérésen alapul. Schwartz 56 érték általános osztályozásával, 44 ország adatainak vizsgálatával, egyéni szinten 10 motivációs típust határozott meg (Schwartz, 1992, 1994). Schwartz elméletében az értékek egyéni értékelésének kevés jelentése van, az értékek egymáshoz való relatív viszonyát vizsgálja, mert a motivációs tartalom az érték klaszterekből és az érték-orientációkból értelmezhető.

A 10 értéktípus elhelyezhető egy kétdimenziós térben, amelynek dimenziói:

- nyitottság vs. konzervativitás (openness to change - conservatism)

- önkiterjesztés vs. önmegvalósítás (self - transcendence -- self - enhancement).

Ezekből a második dimenziót szokták alkalmazni a környezetbarát viselkedés vizsgálatára. Az önkiterjesztés mások érdekeinek figyelembevételét jelenti; ide olyan értékek kerültek, mint az univerzalizmus és a jótékonyság. Az önmegvalósítás a saját érdekek figyelembevételét képezi le, ide tartoznak a teljesítmény és a hatalom értékei (Lányi, 2008). Az önkiterjesztéssel jellemezhető emberek hajlamosabbak a környezetbarát viselkedésre, szemben az individualista értékeket képviselő egyénekkel (Schwartz, 1992; Stern és Dietz, 1994). Karp (1996) kutatása is azt igazolja, hogy az önkiterjesztés és a nyitottság pozitív kapcsolatban van a környezetbarát viselkedésekkel, míg azok, akik az önmegvalósítást és a konzervativitást értékelték jobban, azok negatívan viszonyultak a környezetbarát tevékenységekhez. Ez a tendencia azzal magyarázható, hogy a legtöbb környezetbarát tevékenység az egoista hajlam visszaszorítását igényli (De Groot és Steg, 2008).

\section{Környezettudatosság vizsgálatánál alkalmazott mérések}

A természet és az egyén kapcsolatának a vizsgálata során, azaz a természethez való kötődés kutatása során a környezeti értékek a kapcsolat erősségét meghatározó tényezőként kerülnek elemzésre (Clayton és Opotow, 2003; Gosling és Williams, 2010; Mayer és Frantz, 2004; Olivos és Aragonés, 2011; Olivos és tsai., 2011; Perrin és Benassi, 2009).

A kutatások általában irányultságuk alapján három értékorientációt különböztetnek meg: az első az énre helyezi a hangsúlyt, második a tágabb emberi környezetre, míg a harmadik a bioszférára (Joireman és tsai., 2001; Schultz és tsai., 2005; Stern és Dietz, 1994). 
Ezzel párhuzamban van Merchant (1992) értelmezése, miszerint háromféleképpen lehet érték a környezet az egyén számára aszerint, (1) mi a fontos saját maga szempontjából (egocentrikus), (2) az embereknek általában (antropocentrikus), (3) és a bioszférának (ökocentrikus vagy biocentrikus). Az egoista értékekkel rendelkezők a személyes költségek és előnyök aránya alapján döntenek a környezetbarát tevékenységekről, az altruista a közösség szempontjából, míg a bioszférikus értékekkel rendelkező személyek a természet szempontjából értékelik a költségeket és az előnyöket, és ez alapján döntenek. Mindegyik értékrend vezethet bizonyos esetben környezetbarát viselkedéshez (pl. autóhasználat csökkentése a magas benzinárak miatt), de az alturista és a bioszférikus értékek korrelálnak pozitívan a környezetbarát meggyőződésekkel, normákkal és attitüdökkel (De Groot és Steg, 2008).

Disszertációm elméleti modelljében az értékek a környezeti identitást meghatározó, előrejelző tényezőként szerepelnek. Az értékek vizsgálatát általános értékrend skála alkalmazásával végeztem annak érdekében, hogy a környezettudatos fogyasztói magatartásra gyakorolt direkt hatását is vizsgálva a magatartásformák több típusához is releváns legyen.

\section{ATTITÜD}

Az attitűd olyan kognitív reprezentáció (Smith és Mackie, 2004), amely magába foglalja egy személy értékeléseit egy adott személlyel, csoporttal, dologgal, tettel vagy ötlettel kapcsolatban.

„Az attitüd a tapasztalat révén szerveződött mentális és idegi készenléti állapot, amely irányító vagy dinamikus hatást gyakorol az egyén reakcióira mindazon tárgyak és helyzetek irányában, amelyekre az attitüd vonatkozik" (Allport, 1954 idézi Hofmeister-Tóth és Töröcsik 1996, 65. old.).

Az attitüd tehát egy személy értékelő viszonyulására, megítélésére vonatkozik egy konkrét tárgyra vonatkozóan (Eagly és Chaiken, 1993) és a kedvelés fokában tükröződik vissza. Az attitűd három elemből, kognitív, affektív és viselkedéses információból áll (Smith és Mackie, 2004). A gyakorlatban azonban az attitüd mérések során nem tesznek különbséget a három komponens között (Gross és Niman, 1975). Az alkalmazott állítások vonatkozhatnak érzésekre, meggyőződésekre és viselkedésekre is, és együtt adják az attitüd értékét. 
Más megfogalmazásban az attitűd az értékelés és az értékelt tárgy közötti asszociáció erejét mutatja (Fazio és tsai., 2008). Ha azt hallom, hogy globális felmelegedés mi az első gondolatom? Az, hogy komoly probléma, vagy az hogy nem valós probléma?

Az attitüd előnye, hogy egy egyszerü utat mutat a döntések meghozatalához. Ez a környezetvédelem esetében is fontos tényező, hiszen az egyének egyre inkább azt érzik, hogy túl nagy felelősség számukra a környezettudatos viselkedés megvalósítása (Moisander, 2007). Túl sok és gyakran ellentmondó információkat kapnak, amelyek megnehezítik a döntések meghozatalát.

Az attitüd vizsgálata azért terjedt el, mert feltételezték, hogy az attitüd és a viselkedés között szoros kapcsolat áll fenn. Az attitüd és a viselkedés inkonzisztenciáját azonban mára számos kutatás vizsgálta és igazolta (Fazio és tsai., 1982; Kraus, 1995; Smith és Swinyard, 1983), a környezettudatos fogyasztói magatartás területén is (Vermeir és Verbeke, 2006). Az attitűd és a viselkedés közti résnek a megértése érdekében szükséges vizsgálni az attitüd és a viselkedés között fennálló kapcsolatot.

\section{Attitüd és viselkedés kapcsolata}

Az attitűd és a viselkedés között Kahle és Berman szerint 4 fajta kapcsolat lehetséges (McBroom és Reed, 1992), amelyre az attitűdkutatások során kerestek bizonyítékot: első, hogy a viselkedés az okozója az attitüdnek; második, hogy az attitűd oka a viselkedésnek; harmadik, hogy reciprok viszony áll fenn köztük, illetve negyedik lehetőség, hogy egyáltalán nincs közük egymáshoz. Az is felvetődött, hogy mindkettőt egy harmadik tényező okozhatja.

\section{A viselkedés hatása az attitüdökre}

Adott helyzetben történő viselkedésünkböl gyakran következtetünk attitüdjeinkre. Ilyenkor az önészlelésünk alapján határozzuk meg az adott tárgyhoz kapcsolódó attitüdünket (Smith és Mackie, 2004). Ez a felszínes információfeldolgozás szintje. Másik út lehet, amikor inkonzisztencia jön létre a cselekvésünk, hiedelmeink, érzéseink között, és ez a kényelmetlen érzés motivál minket arra, hogy a kellemetlen érzéstől megszabaduljunk, amit az attitüdjeink megváltoztatásával érhetünk el. Ez a változás tartósabb, mint az önészlelés alapján kialakuló, hiszen ez alapos és szisztematikus feldolgozást igényel az egyéntől. Erre az attitüdváltozásra adnak választ az attitüd modellek (Maccoby és Maccoby, 1961), mint például: 
- Heider egyensúlyelmélete (Aronson és Cope, 1968; Brickman és Horn, 1973; Heider, 1958.)

- Rosenberg, az attitűd dinamikájának strukturális elmélete (Rosenberg és Hovland, 1960)

- McGuire modellje (McGuire, 1979)

- Hovland és munkatársai tanulási elmélete (Hovland és Weiss, 1951)

- Festinger kognitív disszonancia elmélete (Festinger, 2000).

\section{Attitüdjeink hatása a viselkedésünkre}

A szociálpszichológiai kutatások eredményeként kijelenthető, hogy az attitüd gyakran, de nem minden esetben képesek a viselkedések elörevetítésére (Smith és Mackie, 2004). Az attitüdök a viselkedést szintén kétféleképp tudják alakítani:

1, közvetlenül irányítják a viselkedést: ilyenkor nincs szükség nagy erőfeszítést igénylő gondolkodásra, tervezésre. Ez azért lehetséges, mert az attitüd képes arra, hogy a figyelmünket szelektívvé tegye, és csak azokat az információkat „halljuk meg”, amelyek megegyeznek a meglévő véleményünkkel. Emellett a kapott információk értelmezését is torzíthatja az attitűd, hogy az információ illeszkedjen az attitűdhöz.

2, tudatosabb úton irányítják a viselkedést: van olyan helyzet, amikor az egyén arra figyel oda, hogy az attitüdjéhez illeszkedő szándékot alakítsa ki. Ez a szándék tervezést indít el az attitűdhöz illeszkedő viselkedés kialakítására.

Ahhoz azonban, hogy az attitüd irányíthassa a cselekedeteinket, több követelménynek meg kell felelnie. Könnyen hozzáférhetőnek (Smith és Mackie, 2004) kell lennie, amit elősegít, ha egy gyakran használt attitüdről van szó, vagy ha tudatosan gondolkodunk az adott attitüdröl, azaz én-tudatosak vagyunk.

Számos szerző kutatta a viselkedés és az attitüd közti inkonzisztencia okait. Egy átfogó összefoglalást olvashatunk Gross és Niman müvében, ahol személyes, szituatív és módszertani ok-csoportokra vezetik vissza a problémát (Gross és Niman, 1975). Személyes konzisztenciát gátló tényezők lehetnek:

- más befolyásoló attitüd jelenléte

- versenyző motívum jelenléte

- különböző verbális, intellektuális és szociális képességek

- eltérő aktivitási szint eltérő szituációkban.

Szituációs tényezők, amelyek inkonzisztenciát okozhatnak:

- bizonyos személyek jelenléte, vagy jelenlétük képzete 
- a megfelelő viselkedés normatív előírásainak megléte

- alternatív viselkedésformák elérhetősége

- egy adott szituációban a verbális válaszok általánosak, míg a viselkedéses válaszok specifikusak

- elöre nem látható külső események bekövetkezése

- a különböző viselkedések várt illetve valós következményei.

Kiesel szerint a következő módszertani hibák okozhatnak inkonzisztenciát (Gross és Niman, 1975), mint a megbízhatóság, az állítások nehézsége, a kategória szélessége és hogy sikerül-e ténylegesen a viselkedés kapcsán releváns attitüdöt mérni.

McBroom és Reed (1992) szerint nem azt kell vizsgálni, hogy az attitüd okozza-e a viselkedést, vagy fordítva, és hogy fennáll-e a konzisztencia, hanem azt, milyen szituációkban konzisztens a kettő, és mikor nem.

Hines és társai metaanalízise alapján (1986) a környezeti attitűd és a viselkedés között általában pozitív irányú, gyenge kapcsolatot állapítanak meg a kutatások.

\section{Környezeti attitüd: világnézet és környezeti aggodalom}

A környezeti attitűd meggyőződések, érzelmek és viselkedési szándék összessége, amelyet az egyén a környezetbarát cselekvésekkel és kérdésekkel kapcsolatban gondol (Schultz és tsai., 2004). A környezeti attitűd és a környezettudatos viselkedés között enyhe, illetve közepes erősségű kapcsolatot találtak a kutatások (Bamberg és Möser, 2007; Hines és tsai., 1986). Az inkonzisztencia tehát látható a környezeti attitűd és a környezetbarát viselkedés vizsgálataiban is. Az inkonzisztencia kezelésére a kutatások két típusú reakciót adnak. Ajzen és Fishbein hasonlósági elvére (1977) alapozva az általános attitüd vizsgálatokat specifikus attitüddel váltják ki, amely a tárgy, a viselkedés, kontextus és idő alapján megegyezik a viselkedésre vonatkozó mérésekkel, ezáltal biztosítva a közvetlen kapcsolatot. Azt feltételezik, hogy a gyenge kapcsolat a környezeti attitűd dimenzióinak eddig nem teljes meghatározásából ered, átfogó kutatásokkal törekednek a dimenziók meghatározására (Milfont és Duckitt, 2004). Ez azonban kiveszi az általános attitüdök erejét azáltal, hogy nem teszi lehetővé a többféle hasonló tevékenység közös vizsgálatát. Másik megoldásként a különböző további (kontextust befolyásoló) változók modellbe építésével oldják fel az inkonzisztenciát, mint például az észlelt viselkedés hatékonyság vagy a kognitív folyamatok elemzése. 
Véleményem szerint az attitűd hatása komplex folyamaton keresztül jelenik meg a viselkedésben. Kutatásomban azonban nem törekszem specifikus viselkedések vizsgálatára. Mivel a környezetbarát tevékenységeket általánosan, több területet együttesen mérve értelmezem, ezért a környezeti attitűdöt is általános koncepcióban vizsgálom.

A világnézet az attitűd egyik általános értelmezése, amely az egyénnek azon meggyőződéseire vonatkozik, amelyeket az emberiség természettel való kapcsolatáról alkotott (Schultz és tsai., 2004). Az egyén világnézete kognitív paradigma vagy hiedelemrendszer. Dunlap és Van Liere (1978) szerint az egyének környezeti paradigmája az egyének meggyőződés-rendszerének alapvető része. Disszertációm során az Új Környezeti Paradigma Skálát (New Environmental Paradigm Scale, NEP) alkalmazom környezeti attitüd mérésére, amelyet Dunlap, Van Liere és munkatársaik fejlesztették ki (Dunlap és Van Liere, 1978; Dunlap és tsai., 2000).

A NEP skála az 1970-es években uralkodó Domináns Társadalmi Paradigma átalakítása érdekében fogalmazódott meg. Az iparosodott társadalom megjelenése lehetőséget adott az embernek a biofizikai világtól való függetlenség növelésére. A szociológia ekkor az emberi faj különlegességét, kivételességét kezdte hangsúlyozni, amelyet a nyelvre, a technológiai, tudományos és általános kulturális fejlődésre alapozva fogalmazott meg (Dunlap, 2002). Ez a paradigma a környezeti problémák megoldására nem nyújtott lehetőséget, mert az emberre, mint független, minden természeti lény fölött álló személyre tekintett (Hofmeister-Tóth és tsai., 2012b). Catton és Dunlap (1980) elfogadva az emberi faj különlegességét, azt is hangsúlyozza, hogy a speciális képességeink nem mentesítenek a természeti környezet korlátai alól. Ezért az emberi különlegesség paradigmájának $^{10}$ felváltására az Új Ökológiai Paradigmát (New Ecological Paradigm, NEP) javasolták, amely az emberi társadalom ökológiai függőségét hangsúlyozza (Catton és Dunlap, 1980). A NEP a természet és az egyén kapcsolatának felfogását alapjaiban változtatta meg. Az embert a természet részeként kezeli, és ennek következtében megfelelő korlátok közé helyezi (Dunlap és Van Liere, 1978). Dunlap és munkatársai a NEP-et tehát nem specifikus attitüdként kezelik, hanem „ökológiai világnézetként” (Schultz és tsai., 2004). A skálát a világ számos országában alkalmazták már a környezeti attitüd mérésére (Hawcroft és Milfont, 2010), széleskörü elterjedése ellenére azonban kritikákat is nagy számban kapott (Cordano és tsai., 2003), amelyek a skála

\footnotetext{
${ }^{10}$ emlegetik még Human Excemptionalism Paradigm, HEP-ként is Dunlap (2002)
} 
dimenzionalitására és validitására vonatkoztak. A szerzők ezért felülvizsgálták a skálát, azzal a céllal, hogy kiegyensúlyozottabbá tegyék a tételeket, illetve hogy helyettesítsék a korábbi megfogalmazást (Dunlap és tsai., 2000). A NEP skála az ember meggyőződéseit méri a növekedés határainak eléréséről, az anti-antropocentrizmusról, a természeti egyensúly törékenységéről, az emberi kiváltságosságról (anti-exempcionalizmus), és az ökokrízis bekövetkezésének lehetőségéről (ökokrízis). A NEP skála alkalmas a környezeti attitüd és egyéb szocio-ökonómiai változók vizsgálatára, mint a környezeti értékekkel való összekapcsolásra és következtetések levonására, illetve a környezetbarát viselkedéssel való kapcsolat vizsgálatára (Milfont és Duckitt, 2004; Schultz és Oskamp, 1996; Sudbury-Riley és tsai., 2014).

A környezeti attitüd másik általános koncepciójának tekinti a szakirodalom a környezeti aggodalmat. A környezeti aggodalom Schultz és munkatársainak (2004) értelmezésében arra az érzelemre (aggódás) utal, amely a környezeti problémákhoz kapcsolódó meggyőződésekhez kötődik. Véleményem szerint a környezeti aggodalom átmenetet képez az érzelmek és az attitüd között. Amennyiben attitűdként értelmezzük, az attitűd érzelmi komponense túlhangsúlyozott a többi komponenssel szemben. Disszertációmban az általánosan elfogadott szakirodalmi meghatározás alapján az attitűd koncepcióján belül mutatom be, de külön tényezőként kezelem az erős érzelmi fókusza miatt.

Az egyén tehát aggódhat a légszennyezés káros következményei, vagy a veszélyes hulladék nem megfelelő kezelésének következményei miatt. Stern és kollégái a környezet iránti aggodalomnak három típusát határozta meg, amelyeknek a forrása az értékrendben gyökerezik (Stern és Dietz, 1994). Az egoista aggodalom az énre és az én-irányultságú célokra (pl.: hatalom, gazdagság, egyéni siker) vonatkozik, az altruista a többi ember iránti aggodalmat jelenti (pl.: család, közösség, emberiség), míg a bioszferikus aggodalom az összes élőlény (pl.: állatok, növények) iránti aggodalmat jelenti. A környezeti problémák iránti aggodalom cselekvést indukálhat, ha aktiválódnak (Schultz, 2000, 2001; Schultz és tsai., 2005).

Disszertációm kutatási kérdése kapcsán a környezeti aggodalom vizsgálatát azért tartom kiemelten fontosnak, mert Schultz koncepciójában egy tárgy értéke valaki számára azon múlik, hogy az adott személy én-fogalmának mennyire része az adott tárgy (Schultz, 2000). Schultz feltételezi, hogy a környezeti aggodalom és az egyén én-fogalma szoros kapcsolatban van, az aggodalom függ attól, hogy az egyén mennyire határozza meg 
önmagát másoktól - bármely más élőlénytől - függetlennek vagy kölcsönösen függőnek. A környezeti problémák miatti aggodalom tehát szorosan összekapcsolódik azzal, hogy az egyén mennyire érzi önmagát a természet részének. Azok, akik a természettel összekapcsoltnak érzik magukat, azoknak egy kibővített én-fogalmuk van, amely más, nem emberi élőlényeket is magába foglal, és így erősebb bioszférikus aggodalomhoz vezet. Ezzel szemben azok az egyének, akik kevésbé érzik kapcsolatban magukat a természettel, azokat a tárgyakat tartják fontosabbnak, amelyek egyéni értékeket jelképeznek (Schultz, 2000). Schultz és munkatársai a bioszferikus aggodalom, valamint a természet és egyén implicit asszociációs értéke között pozitív kapcsolatot talált, és negatívat az egoista aggodalom esetében (Schultz és tsai., 2004).

Ez az elmélet tehát a környezeti aggodalom mediátor szerepet feltételezi a természethez való kötődés és a környezetbarát viselkedés viszonylatában. Erre a mediáló hatásra azonban egyenlőre csak részleges bizonyíték van (Gosling és Williams, 2010). Disszertációm során ezt a kapcsolatot is vizsgálom.

A magasabb társadalmi rétegbe való tartozás és a magasabb iskolai végzettség erősebb környezettudatos aggodalomhoz vezet (Winter és Koger, 2004). Ez azzal indokolható, hogy az oktatás szocializációt és plusz információkat nyújt a környezeti kérdések kapcsán, míg az alacsonyabb státusz esetében az aggodalom inkább a közvetlenebb, azonnali problémákra irányul (pl.: bünözés, megélhetés). Emellett a kor és a politikai beállítódás is erős meghatározó tényezőnek bizonyult, a fiatal, magas végzettségü, liberális gondolkozású személyek erősebb környezeti aggodalmat mutattak (Jones és Dunlap, 1992). Igazodva a környezetbarát fogyasztó jellemzőihez, a nők és a városi lakosok hajlamosabbak a környezetért aggódni, de ezek az eredmények kutatásonként enyhén változtak.

A környezeti attitüd alatt, ahogy a fenti sorokból is látható több koncepció is értelmezhető. Az egyik legelső környezeti attitűd mérés például 4 alskálát tartalmazott, az attitűd keretein belül vizsgálva a szóbeli és valóságos elköteleződést, az érzelmi affinitást és a specifikus ökológia tudást (Maloney és Ward, 1973). Napjainkra a környezeti tudásra és a környezeti értékekre általában a környezeti attitüdöt meghatározó tényezőként tekintenek (Bamberg, 2003) és a valós viselkedés sem része az attitűd koncepciójának. A környezeti attitüd és az aggodalom fókusza napjainkban a környezetvédelemnek a kognitív és az affektív értékelésére irányul. Ebben a 
kontextusban nem meglepő, hogy a környezeti attitüdöt és a környezeti aggodalmat a szakirodalom gyakran szinonimaként kezeli (Milfont és Duckitt, 2004).

Elfogadom azt a szemléletet, hogy az attitűd széles értelmezési keretébe a környezeti világnézet és a környezeti aggodalom is bele van foglalva. A környezeti identitás széleskörü vizsgálatához disszertációmban mind a világnézet, mind az aggodalom koncepcióját vizsgálom. A NEP alkalmazásával mért világnézetet annak érdekében alkalmazom, hogy a környezetbarát viselkedéssel való kapcsolatát értékeljem és a hatás erősségét összevethessem a környezeti identitás hatásával. A környezeti aggodalom kutatását az én-fogalommal való szoros kapcsolata miatt tartom szükségesnek, és mint a valós viselkedéssel való kapcsolat mediátorát értékelem.

Összefoglalva a pozitív környezeti attitüdöt a környezetbarát viselkedés kialakulásában az egyik legerősebb hatással lévő pszichográfiai tényezőnek tekinti a szakirodalom. Vizsgálata során azokra a körülményekre érdemes fókuszálni, amelyek a kapcsolat erősségét alakítják. Jelen kutatásban a környezeti attitüdöt, mint a környezeti identitás és a környezetbarát viselkedés közötti kapcsolatot mediátor tényezőt veszem figyelembe.

\section{NORMA}

A norma a társas közeg, a társadalom közösen osztott meggyőződése arról, hogyan kell bizonyos szituációkban viselkedni (Cialdini és tsai., 1990; Schwartz és Howard, 1982). A normákat meg kell különböztetni az alapján, hogy mennyire internalizálódtak, így beszélhetünk személyes vagy társas normáról (Thøgersen, 2006). A társas normák olyan szabályok és sztenderdek, amelyeket a csoport minden tagja ismer és törvényi szabályozás nélkül irányítja a viselkedést (Cialdini és tsai., 1990). A normák implicit szabályok, elvárások arról, hogy adott szituációban milyen viselkedés a követendő. Ha azt látjuk, hogy elfogadott norma a szemetelés az utcán, akkor az emberek hajlamosabbak tovább szemetelni, szemben azzal, ha tiszta környezetben lennének. A társadalmi normák a mások viselkedéséről való hiedelmeink összességét jelentik, a társas nyomáson keresztül hatnak és jelentős hatással vannak a csoportok kohéziójára (Ajzen, 1988).

Az egyéni normák a kötelesség érzéseként jelennek meg, arra vonatkozóan, hogy megadott módon viselkedjünk. Schwartz meghatározásában a személyes norma alatt azokat a viselkedés elvárásokat érti a személy részéről, amelyek adott szituációban egy morális kötelességérzetként jelennek meg az adott viselkedés elvégzésére (1977, idézi Thøgersen, 2006). Ebben az értelemben a személyes normák belső okoknak tesznek 
eleget, a belsővé tett értékekhez hasonlóan. Az egyéni normák követéséhez is megerősítésre van szükség, de ilyenkor a megerősítés is belső, mint például a büntudat érzése, önbecsülés csökkenése, negatív önértékelés (Thøgersen, 2006).

A normák további csoportosítását jelenti az előíró normára és leíró normára való bontás. Az elöíró norma az általában jóváhagyott vagy megtagadott viselkedésre vonatkozik, amely azáltal motivál, hogy társas jutalmazást vagy büntetést von maga után. Az olaj lefolyóba öntése például egy előíró norma, mert a tevékenységet általános társadalmi elutasítás veszi körül. A leíró norma ezzel szemben azokat a viselkedéseket jelenti, amelyeket a csoport legtöbb tagja végez. Az elöíró norma általában informális megerősítés által fejti ki hatását, míg a leíró norma példa követés által. Az alkalmazkodás a motiváló hatás abban az esetben, amikor olyan tevékenységet végzünk, amelyet mások is (Cialdini és tsai., 2006). Ilyen lehet például az az információ, hogy a helyi lakosság nagyobb része szelektíven gyüjti a hulladékot.

A környezetbarát viselkedésformák végzése általában mind személyes, mind társas normákkal korrelál, azonban a kutatások azt mutatják, hogy a társas normák hatása gyengébb, és a viselkedés kialakulása inkább a tevékenységhez kötődő egyéni normák erősségétől függ (Thøgersen, 2006). A normák kialakulása során a specifikus viselkedésekhez kötődő normák fejlődnek ki először, majd ezek az egyedi normák válnak általánossá és válnak kiszélesíthetővé eltérő tevékenységekre is (Thøgersen és Ölander, 2003). Annak érdekében, hogy a norma közvetlen hatást gyakoroljon a környezetbarát viselkedés kialakulására a normának fokálisnak, központinak kell lennie (Cialdini és tsai., 2006). A normák kommunikálása ennek megfelelően segítséget nyújthat a környezetbarát viselkedések kialakításában. A normák jelentőségét csökkenti, hogy számos környezetbarát cselekvés nem nyílt, mások számára is látható módon történik, hanem otthon zárt ajtók mögött. Ilyenkor lehet szükség a normák törvényi szabályozására (Winter és Koger, 2004).

A norma hatása a környezetbarát cselekvésekre tehát akkor erösebb, ha az adott norma minél inkább internalizálódott az adott személyben. Ez összhangban van a korábban bemutatott értékek hatás vizsgálatának az eredményeivel is. Disszertáció kutatásom során ezért az egyéni normák mediátor hatását veszem figyelembe. Az egyéni normában megjelenik a személy felelősségérzete, kötelességtudata, hogy milyen mértékben tartja a saját kötelességének a természet védelmét. 


\subsection{Gestalt ELMÉLET ÉS ÖKOPSZICHOLÓGIA}

A holisztikus szemléletből kiindulva - ahol az egész több, mint a részek összessége - a környezetvédelmet is a kialakult rendszer részeként kell vizsgálni. Az elmélet lényege, hogy a környezeti problémák abból fakadnak, hogy nem tudjuk a teljes képet, azaz az egész rendszert, mint viselkedésünk teljes hatását látni. Ezt a „beszükült” látásmódot támogatja napjaink modern világnézete, amely az individualizmust hangsúlyozza, azt, hogy a dolgok elválaszthatóak egymástól, az egyének elválaszthatóak a kultúrájuktól vagy a természeti világtól (Winter és Koger, 2004). A gestalt (alaklélektan) képviselői szerint a belátásos tanulás során ismerünk meg új dolgokat. A tanulás az észleléstől függ, a percepciós újrarendezéstől.

A vázolt holisztikus szemléleten alapulva, abból kiindulva alakult ki az 1990 években az ökopszichológia irányzata (Koger és Scott, 2007). Alapelve szerint, ahhoz hogy az egyének felismerjék és kezeljék a környezeti problémákat, az önészlelésükön kell változtatni. A hagyományos önálló én nézete félrevezető és veszélyes. Arne Naess (1985) fogalmazta meg először, hogy meg kell ismernünk az ökológiai énünket. Ahhoz, hogy a környezetkárosító viselkedésünket meg tudjuk változtatni szükséges a nagyobb, a környezettel kapcsolatban álló én megtapasztalása (Bragg, 1996). Az urbanizált közegben a természettel kapcsolatban lévő én érzése gyengül az egyénben, amely pszichológiai stresszt okoz (Roszak és tsai., 1995). Az ökológiai ént akkor tapasztalhatjuk meg, ha érezzük a kapcsolatot más egyénekkel, más életformákkal, az ökoszisztémával és a Földdel. Az ökológiai én esetében több dimenziót lehet meghatározni, Bragg ebből 3-at emelt ki (1996):

- kognitív: az emberek és egyéb fajok, valamint az ökoszisztéma jól-létéről szóló információkra való érzékenység

- érzelmi: törődés, empátia, és összetartozás érzése más emberekkel, fajokkal és az ökoszisztémával

- motivációs: aggodalom és szándék arra, hogy az ember, a többi faj és az ökoszisztéma jól-létét biztosítsa. 
Az ökológiai én elömozdítja a környezetbarát tevékenységeket, de nem önfeláldozás, vagy önmegtagadás által, hanem a szeretet és a közös identitás indíttatásából. Az identifikáció ${ }^{11}$ következtében az én-szeretete miatt lesz fontos a környezetvédelem.

Az ökopszichológia a természeti környezetben történő emberi tapasztalást vizsgálja. A személyiség elsődleges részének az ökológiai tudattalant tartja (Roszak, 1992), mert ezek a korai emlékek a környezettel való kölcsönösség érzését adják. Az ökopszichológia úgy gondolja, hogy az ember az ökológiai környezettel való egység érzésével született (Clayton és Opotow, 2003).

Az ökopszichológia irányvonala ismerte fel a környezettől való elszakadás káros hatásait, és kezdte el vizsgálni a környezetbarát viselkedés kialakulásában a személyiség szerepét. A következő fejezetben a környezeti identitás alapjait adó személyiségelméleteket mutatom be, majd tovább részletezem a környezeti identitás koncepcióját, kialakulását és mérési lehetőségeit. Az ökopszichológia gondolati köréhez az 5. fejezetben térek vissza, ahol az identitás és a természet kapcsolatát vizsgálom mélyebben.

\footnotetext{
11 azonosulás
} 


\section{SZEMÉLYISÉG}

A személyiség fogalmát hétköznapjaink során gyakran alkalmazzuk, ha valakit jellemezni szeretnénk. A pszichológia tudománya a hétköznapi, naiv használatnál komplexebben közelíti meg a témakört, de a személyiség definiálása esetében még sincs konszenzus. Az eltérő irányzatok módosítják értelmezéseiket, de a fogalomnak vannak olyan alapvető jellemzői, amelyek általánosan elfogadottak. A pszichológia oktatásban használt alapvető definíció a személyiségre a következő:

„A személyiség a személyen belüli pszichofizikai rendszerek olyan dinamikus szerveződése, amely a személyre jellegzetes viselkedés-, gondolat- és érzésmintázatokat létrehozza." (Carver és Scheier, 2006, 30-31. o.)

A definíció fontos eleme, hogy a személyiség szerveződés, azaz nem különálló elemek halmaza. A személyiség megnyilvánulása aktív folyamat, és kötődik a fizikai testhez. A személyiség ismétlődő, különböző helyzetekben is állandó mintázatokban jelenik meg, mind a viselkedésben, a gondolatokban, az érzelmekben. Oksági tényező, amely segíti meghatározni a személyek világhoz való viszonyát (Carver és Scheier, 2006).

A pszichológia tudomány esetében is megfigyelhető, hogy minden korszakának van egyegy kiemelkedő, „mainstream” kutatási érdeklődése, mint a tanulás, attitűd, attribúció, affektus. Az én, mint egységesítő fogalom az 1970-es évektől vált jellemző kutatási területté (Pataki, 2008). Az én-pszichológia területén a kapcsolódó fogalmak (én, identitás, személyiség) egymáshoz való viszonya napjainkban sem kellően tisztázott, gyakori a tetszőleges, szinonimaként való használatuk. „Az én-vonatkozású jelenségek ma már nem meghatározott, élesen körvonalazott tárgyat jelentenek, hanem egy szerteágazó fogalom- és jelenségkört” (Pataki, 2008, 411. o.).

Ezt támasztja alá Markus és Cross (1990) véleménye is, miszerint az én-pszichológiai perspektívája az össz-személyiségtől az egyén vágyott személyiségére is kiterjedhet (Markus és Cross, 1990 idézi: Pataki, 2008, 411.o.). Levin 1992-ben összegyüjtötte a lehetséges én-értelmezések kilenc fajtáját, amelyek: lélek, szubsztancia, aktivitásmód, 
magyarázó hipotézis, kognitív struktúra, nyelvi aktivitás, affektív élmény, képzetáramlási folyamat, ösztönelvü normatív szerveződés. Leary és Tangney (2003) az én jelentésének öt fajtáját azonosította:

- a teljes személyt;

- a személyiséget, mint a pszichológiában hagyományosan használt fogalmat;

- az én-élmény alanyát, azaz általában a szubjektív élmények alanyát;

- az én-képben, én-fogalomban, én-sémákban leképeződött, önmagunkról birtokolt ismeretek, hiedelmek (észleletek, gondolatok, fantáziák, érzelmek) összességét; illetve

- a végrehajtó-ellenőrző és szabályozó ágenst, vagyis a viselkedés pszichikus önszabályozásának szervét.

Ezeket a jelentéseket nem egymást kizáró funkcióknak kell tekinteni, hanem egy rendszer összetevőinek vagy dimenzióinak (Pataki, 2008).

A különböző pszichológiai irányzatok eltérő módon magyarázzák a személyiséget, a kialakulását (részletesen lásd: 3. fejezet). A pszichoanalitikusok szerint például az énkép a szeparáció során alakul ki, amikor a gyermek megtanulja megkülönböztetni önmagát másoktól (Carver és Scheier, 2006). A mélylélektan ego-fogalma s annak újabb értelmezési változatai (mint Hartmann, Erikson, Kohut; a humanista pszichológia önaktualizálási eszméje) merőben más mederben haladnak, mint az én társas-szociális eredetét hangsúlyozó tradíció (Mead szimbolikus interakcionizmusa) vagy a kognitív forradalom kézjegyét magán viselő felfogás, amely az énről, mint kognitív struktúráról vagy identitás-kategóriák alakzatáról beszél (Pataki, 2008). A személyiség ezen felfogás szerint a társas értékelésből származik, azaz a véleményünk önmagunkról azon alapul, milyen visszajelzéseket kapunk másoktól.

Az én-fogalom (self-concept) használatára az eltérő paradigmák eltérő munkadefiníciókat alkalmaznak. Az én-fogalom paradigmáinak elkülönítése esetében három kritikus szempontot lehet meghatározni (Reed, 2002):

- hogyan határozza meg a paradigma az én-fogalmat, azaz milyen komponenseit határozza meg, ezáltal meghatározva a fogalom dimenzionalitását;

- milyen mértékben fókuszál a paradigma az én-fogalom külső, illetve belső aspektusaira, azaz inkább a belső, pszichológiai aspektusait hangsúlyozza az énnek, vagy a külső, társadalmilag meghatározott jellemzőit;

- mi az én-fogalom elsődleges funkciója. 
Az én paradigmák ismerete hozzásegíti a kutatót, hogy a megfelelő koncepciót alkalmazza kutatása során, amely a legkörültekintőbben tudja magyarázni a szükséges szempontokat. A kutatásom során a szimbolikus interakcionizmus identitás fogalmából indulok ki a környezeti identitás értelmezése során. A személyiség koncepciók összehasonlítása érdekében a klasszikus pszichológiai irányzatok személyiség felfogását a 3. táblázatban foglaltam össze.

\begin{tabular}{|c|c|c|c|}
\hline Személyiségelmélet & $\begin{array}{l}\text { Én-fogalom } \\
\text { irányultsága }\end{array}$ & EImélet alapja & $\begin{array}{l}\text { Elmélet fontosabb hatásai a } \\
\text { fogyasztói magatartásra }\end{array}$ \\
\hline $\begin{array}{l}\text { Pszichoanalitikus } \\
\text { én-felfogás }\end{array}$ & $\begin{array}{l}\text { A személyiség } \\
\text { veleszületett, belső } \\
\text { meghatározottságú. }\end{array}$ & $\begin{array}{l}\text { Elismeri a tudattalan, } \\
\text { belső, irracionális } \\
\text { elemeit a } \\
\text { személyiségnek. }\end{array}$ & $\begin{array}{l}\text { A viselkedés mögötti mély } \\
\text { motivációkat kiemeli, a } \\
\text { fogyasztás szimbolikus } \\
\text { jelenségét hangsúlyozza, amely } \\
\text { tudattalan szinten van. } \\
\text { Ezzel magyarázható például a } \\
\text { környezettudatos fogyasztás } \\
\text { esetében a túlfogyasztást } \\
\text { generáló impulzusvásárlás } \\
\text { kialakulása. }\end{array}$ \\
\hline $\begin{array}{l}\text { Behaviorista } \\
\text { én-felfogás }\end{array}$ & $\begin{array}{l}\text { A személyiség külső } \\
\text { meghatározottságú. }\end{array}$ & $\begin{array}{l}\text { A viselkedés } \\
\text { környezeti, } \\
\text { szituációs } \\
\text { faktorainak a } \\
\text { hatásait magyarázza. }\end{array}$ & $\begin{array}{l}\text { Kiemeli a vásárlás ön- } \\
\text { jutalmazó funkcióját, amely } \\
\text { pozitív megerősítések által } \\
\text { támogatja a fogyasztást. Az ön- } \\
\text { jutalmazás funkciója az én- } \\
\text { fenntartás, a pozitív énkép } \\
\text { kialakítása. }\end{array}$ \\
\hline $\begin{array}{l}\text { Kognitív } \\
\text { én-felfogás }\end{array}$ & $\begin{array}{l}\text { Az én külső és belső } \\
\text { meghatározottságú } \\
\text { is. }\end{array}$ & $\begin{array}{l}\text { Az én a teljes én- } \\
\text { vonatkozású tudás az } \\
\text { emlékezetben. }\end{array}$ & $\begin{array}{l}\text { Kiemeli az én releváns }{ }^{12} \\
\text { információk fontosságát a } \\
\text { fogyasztás során. }\end{array}$ \\
\hline $\begin{array}{l}\text { Szociálpszichológia } \\
\text { én-felfogása }\end{array}$ & $\begin{array}{l}\text { Az identitás külső } \\
\text { meghatározottságú. }\end{array}$ & $\begin{array}{l}\text { Az én-fogalom tehát } \\
\text { az egyén önmagáról, } \\
\text { mint tárgyról } \\
\text { alkotott } \\
\text { gondolatainak és } \\
\text { érzéseinek az } \\
\text { összessége. }\end{array}$ & $\begin{array}{l}\mathrm{Az} \text { én társas termékként és } \\
\text { társas erőként való felfogása. A } \\
\text { társadalmat és az én-t iker- } \\
\text { születésü fogalmaknak tekinti. }\end{array}$ \\
\hline $\begin{array}{l}\text { Szimbolikus } \\
\text { interakcionizmus }\end{array}$ & $\begin{array}{l}\text { Az identitás külső } \\
\text { meghatározottságú. }\end{array}$ & 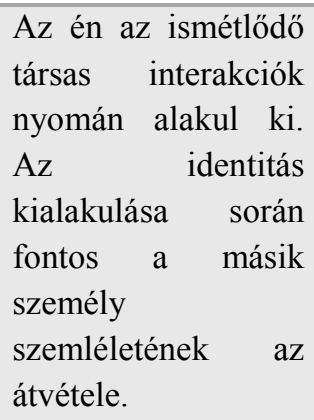 & $\begin{array}{l}\text { A fogyasztást a társas } \\
\text { szerepeknek való } \\
\text { megfeleléshez kötötte. } \\
\text { Megjelenik a másokkal való } \\
\text { azonosulás hatása, hogy az } \\
\text { egyének a döntéseik során } \\
\text { figyelembe veszik a társas } \\
\text { szerepeiket. }\end{array}$ \\
\hline
\end{tabular}

12 valamilyen szempontból az adott identitáshoz erősen kötődő információ, amely közelebb viszi a terméket/ döntési alternatívát az egyénhez 


\begin{tabular}{|c|c|c|c|}
\hline $\begin{array}{l}\text { Szociális identitás } \\
\text { elmélet }\end{array}$ & $\begin{array}{l}\text { Az identitás külső } \\
\text { meghatározottságú. }\end{array}$ & $\begin{array}{l}\text { A társadalom } \\
\text { identitásformáló } \\
\text { szerepe mellett a } \\
\text { csoportközi } \\
\text { kapcsolatok hatására } \\
\text { helyezi a hangsúlyt. } \\
\text { A csoporttagsághoz } \\
\text { füződő értékek és } \\
\text { érzelmi jelentőségük } \\
\text { határozza meg az } \\
\text { ént. }\end{array}$ & $\begin{array}{l}\text { Az identitás az azonosulás } \\
\text { jelentőségét hangsúlyozza. A } \\
\text { társas identitás leíró, elöíró és } \\
\text { értékelő is, meghatározza a } \\
\text { csoporttagok elvárt } \\
\text { viselkedését. }\end{array}$ \\
\hline
\end{tabular}

3. táblázat: A bemutatott személyiségelméletek föbb jellemzői

Forrás: saját szerkesztés

A továbbiakban a szociálpszichológia én-elméleteivel foglalkozom részletesebben, bemutatva a szimbolikus interakcionizmus és a szociális identitás elméletet. A kiemelés oka, hogy a marketing orientációval rendelkező kutatások általában ezekre az elméletekre építenek és a környezeti identitás koncepciója is ezen alapul. Kiindulásként azonban érdemes meghatározni a személyiség, az én és az identitás közti különbséget.

Az én (self) az érzelmek, gondolatok és identitások egy szervezett és interaktív rendszere (Owens és Samblanet, 2013). A pszichológiában napjainkban az én a kognitív reprezentációk készletének tekinthető, amely az egyén személyiségvonásaira reflektál és a személyes élmények és élettapasztalatok által kialakított. Az identitás újabb fogalom a szociálpszichológiában, és az én szélesebb koncepciója foglalja magába. A fő különbség, hogy az én egy folyamatnak tekinthető és az ön-reflexió folyamatából születik meg. Ezzel szemben az identitás egy eszköz, amellyel az egyének vagy csoportok meghatározzák, és bemutatják önmagukat a világ számára (DeLamater és Myers, 2011). Szélesebben meghatározva az identitás azon kategóriákat jelenti, amelyeket az egyén önmaga meghatározására használ annak érdekében, hogy elhelyezze önmagát másokhoz viszonyítva (Owens és Samblanet, 2013). Így az identitás tartalmazza a másoktól való megkülönböztető jelleget (én nem olyan vagyok, mint ő, hanem...) illetve a másokhoz való hasonlóság érzését is.

\subsection{A TÁRSAS KAPCSOLATOK JELENTÖSÉGE, A SZIMBOLIKUS INTERAKCIONIZMUS}

A szimbolikus interakcionizmus (későbbiekben SI) az interakciót, a kölcsönhatásokat keresi, és abból igyekszik magyarázni a viselkedést (Buda, 1968). A szimbolikus szó 
jelentősége abban áll, hogy hangsúlyt ad az emberi viselkedés szimbolikus rendjének. A szimbólumok nyelvi és konceptuális természetüek, amelyek jelzések egy bizonyos viselkedés kiváltására. A SI kiindulása, hogy „a társadalom elsősorban sajátos jelentésrendszer, jelentést, értelmet közvetítő összefüggések szövevénye, a személyiség ehhez az összefüggésvilághoz viszonyítva viselkedik, belső kognitív struktúráiban ennek az összefüggésvilágnak lenyomatát viseli” (Buda, 1968, 14. o.). A viselkedést tehát nem lehet a társadalomtól, annak szimbolikus jelentésvilágától függetlenül vizsgálni.

A szimbolikus interakcionizmus (SI) alapjai az emberi természetről alkotott filozófiából ered, amely a skót moralizmuson alapul, amelyet az 1700-as években uralkodó pesszimista és túl individualista világnézettel szemben alakítottak ki (McCall, 2013). Három alapvető tételből indul ki:

A: Minden embernek közös természete van, amely minden más állattól eltér, de az ember társadalmi különbségei által változik.

B: Az emberek általában a társadalmilag megfelelő, célravezető módon viselkednek.

C: Az emberi magatartás ön-irányított.

A skót moralizmus mellett a neokantianizmusban és az evolucionalizmus gyökerezik az irányzat. Az európai gyökereit a SI-nak az amerikai filozófia és pszichológia vitte tovább. Kiemelendő a filozófiai pragmatizmus a cambridge-i és a chicago-i egyetemen, ahol a hangsúly az adaptáción (mint az evolucionalizmus) és a tapasztalatokon (mint a kantianizmus) van (Lewis és Smith, 1980). A chicago-i iskola filozófusai közé tartozott George Herbert Mead, aki a SI központi figurája (McCall, 2013).

Mead nézete szerint az állatok a gesztusaikkal fejezik ki szándékaikat, azáltal kommunikálnak. Ezzel szemben az embereknek más jelzési rendszerei is vannak, mégpedig a szimbólumok, amelyek ugyanolyan válasz tendenciákat váltanak ki a személyekből és a megfigyelőből is. A megfigyelő és az egyén azonos helyzetbe kerülnek, és ez lehetőséget biztosít az egyénnek a másik felé irányuló szerepelvárás felvételére. Mead az én fejlődését az interakciókkal és a szerep felvétellel magyarázta (Buda, 1968). Az én a szimbolikus kommunikációs kölcsönhatásokban (interakciókban) alakul ki, olyan módon, hogy hatékonyan csak akkor tudunk kommunikálni, ha átvesszük a másik személy nézőpontját. Mead szerint az egyénnek önmagát is tárgyként kell észlelnie (Mead, 2000). Ezt csak tapasztalás útján tanulhatja meg. A másik szemléletének az átvételére irányuló próbálkozások során kialakítja az általános másik perspektíváját (Mead, 2000). A szimbólumok használatával együtt jár az is, hogy a „mások” nem csupán 
szituációhoz kötött személyek, hanem általánosítható mások, ami magába foglalhatja számos egyén véleményét.

Mead továbblép Smith (1759, idézi McCall, 2013) tükör-én koncepcióján (azaz olyannak látni magunkat, ahogy mások látnak), értelmezése szerint a mások által meghatározott szerepek felvétele már egy jelentős különbség. A szerep az interakciókon át a személyiségbe épült adaptív viselkedéskészlet (Buda, 1968). A beszéd és a nyelv által az emberi tudat dominál és így az ember képessé vált internalizálni a kiemelkedő szimbólumokkal történő kapcsolatot. Az én akkor kezd el létezni, ha az általános másik belsővé tett perspektívája kialakult. Ezután cselekvéseink értékelésekor is figyelemmel leszünk erre a belsővé tett nézőpontra (Carver és Scheier, 2006). Az identitást a társas pozíciókhoz kapcsolódó szerep-követelmények alakítják ki, és az identitás - a „kognitív válaszok önmagunkra, mint tárgyra" (Stryker, 1987) - hozza létre az ént. Így az énszabályozás belső válik, amely miatt az én megosztottságát feltételezte Mead a biológiai én magra („I”), mint az egyén impulzív része és a szociális énre („Me”), mint a reaktív oldal, amely a másoktól átvett keretrendszert testesíti meg (Buda, 1968).

Szociológiai nézőpontból a hangsúly az egyén és az őt körülvevő személyek közötti kapcsolat jelentőségén van. A SI paradigmája azt a kérdést mérlegeli, mennyire az egyéni következetesség vagy a köz-megnyilatkoztatások által irányított az emberi viselkedés; a társadalmat és az én-fogalmat fontos egységes elemzési egységnek tekinti.

Az elmélet fö képviselői között a szociológiában megtalálható Charles Horton Cooley. Cooley az ént és a társadalmat „iker” születésünek tekintette, ezzel indokolva, hogy az én-fogalmat erőteljesen befolyásolja, mit gondolnak róla a ,,jelentős mások”. Az énfogalom az egyén és a releváns társadalmi környezete közötti kommunikációs interakciókból alakul ki. Cooley szerint az én-fogalom fő eleme a változatos társas én, amelynek fő motivációja az önbecsülés (Reed, 2002). A paradigma feltevése tehát, hogy az egyének mások szemén keresztül látják önmagukat, és a mások visszajelzései alapján alakítják ki én-fogalmukat.

A pszichológia területén James Mark Baldwin (lásd: Baldwin, 1897) és William James (lásd: James, 1890) hangsúlyozták először az emberi természet társadalom általi meghatározottságát. James szerint az én a kulcs az egyén környezethez való adaptációjában. Emellett James volt az első, aki megkülönböztette az „,I”-t, mint én, aki tud és a „Me”-t, mint én, az ismeret, ami a társas ént hangsúlyozza. A klasszikus SI 
képviselője Blumer is, aki először alkalmazta magát az elnevezést (McCall, 2013). Blumer, mint Cooley a szimbólumok és jelek kiemelt jelentőségét hangsúlyozta.

Szintén a SI képviselője Goffman (1959), aki megkülönböztette a társas identitást a személy-identitástól és az ego-identitástól (Goffman, 1959; idézi Reed, 2002). Goffman mellett Turner is komoly szerepet játszott a SI alapjainak megerősítésében azzal, ahogy a szerep-felvételről és a szerep-kialakításról gondolkozott és kialakította az én keretrendszerét, mint szerep (Turner, 1978). A SI fókusza nem csak az egyén megjelenésének a megítélésén van, hanem azon, hogy az egyén hogyan tudja befolyásolni azt, ahogyan mások megítélik (Goffman, 1959). A szerepekről való gondolkodás átalakult, nem egyszerüen átvett, felvett a szerep, hanem a társas közeggel való megegyezés folyamata a szerep-kialakítás. A társas szituációkat társas meghatározottságúnak tekintették, amelyben az énről, a szerepkialakításról és egyéb folyamatokról is kollektív egyeztetés folyik. Így a társas én is társas tárggyá vált, amelyről egyeztetés folyik. Ez a nézet a korábbi 2 részre osztott én-t 3 részre bontja, az „I”, a „Me” és a „self” mint a társas tárgy (Goffman, 1959).

A SI keretein belül kezdtek el a pszichológusok foglalkozni a referencia csoportok vizsgálatával is, amelyet olyan csoportnak tekintettek, amelyhez a személyek nagyon erősen viszonyulnak érzelmileg és értékviszonyait és normáit magáénak tekintik (Buda, 1968).

Az elméletet a fogyasztói magatartás kutatásában alkalmazta többek között Solomon (1983), aki arról értekezik, hogy bizonyos termékek vásárlása során olyan fogyasztói élményben részesül a vásárló, amely hozzájárul társas valóságának, én-fogalmának és viselkedésének kialakításához. A fogyasztók a társas szerepek teljesítése során gyakran támaszkodnak olyan társas értelmezésekre, amelyek a termékekhez kapcsolódnak, különösen, ha a szerep valami újdonságot igényel (Solomon, 1983). Solomon a szimbolikus interakcionizmus koncepcióját integrálta a marketing kutatásba, és úgy vélte, hogy a termékeket nem meghatározott igényekre és szükségletekre adott post hoc válaszként kell tekinteni, hanem figyelembe kell venni, hogy a termékeknek olyan szimbolizmusa lehet, amely a priori befolyásolhatja a viselkedést (Reed, 2002).

A szimbolikus interakcionizmus elméletén alapul az Identitás Elmélet (Stryker, 1987) és a Szociális identitás elmélet (Tajfel, 1982), amely számos átfedéssel bír az Identitás elmélettel (Stets és Burke, 2003). A továbbiakban ezzel a két elmélettel zárom a személyiségelméletek bemutatását. Ezen elméletek behozva a társadalom és a csoport 
hatását az identitásra és a viselkedésre számos marketing orientációval rendelkező kutatás elméleti alapját képezik.

\subsection{IDENTITÁS ELMÉLET}

Az identitás elmélet Blumer tradicionális (mead-i) szimbolikus interakcionizmus elméletén (Blumer, 1969) és Kuhn strukturális szimbolikus interakcionizmus elméletén (Kuhn, 1964) alapul. Ahogy már bemutattam, a SI hangsúlyozza, hogy az identitás mindig a társas struktúrába van ágyazva. Ez a struktúra egyszerre támogatja és gátolja a társas kapcsolatokba való be és kilépését az egyénnek, amely során az identitás kialakul. Az identitás elmélet központi fogalma az én (self), amely számos jelentésből és identitásból épül fel, amelyek az én-struktúrában hierarchikusan helyezkednek el (Stets és Serpe, 2013). Az elhelyezkedést az identitás központisága és észlelhetősége határozza meg. Az identitás alatt azokat a mások által is osztott társas jelentéseket értjük, amelyek az egyén bizonyos szerepekben önmagának tulajdonít (Burke és Reitzes, 1991). A jelentés az egyén reakcióinak az összessége, amikor önmagáról gondolkozik bizonyos szerep, csoport vagy személyes identitás esetében (például ha mind munkavállaló hatékonynak tartom magam, akkor a hatékony a jelentés az adott szerep identitásban). Az identitás tehát meghatározza az egyén szerepét az interakcióban, irányítja a viselkedését, erősíti a stabil társas kapcsolatok kialakítását és lehetővé teszi az interakciókat (Stets és Serpe, 2013).

Burke és Reitzes szerint több megkülönböztető jellemzője van az identitásnak (1991):

- az identitás társas termék, amely a társas folyamatok által alakul ki, marad fenn és szilárdul meg,

- az identitás én-jelentés (self-meaning), amely adott szituációkban sajátítható el az ellentétes szerepekkel való hasonlóságok és eltérések alapján.

- az identitás szimbolikus, ugyanazokat a válaszokat váltja ki egy emberből, mint a többiböl,

- az identitás reflexív, az egyének referenciapontként használhatják az identitásukat saját és mások viselkedésének következményeinek a meghatározásához.

- az identitás a társas jóváhagyás eredménye.

Ebben az elméletben az identitás három kategóriában értelmezett (Stets és Serpe, 2013): 
- Szerep identitás: jelentések egy csoportja, amely azokhoz a szerepekhez kötődik, amelyeket az egyén a társas struktúrában felvesz, például környezetvédő identitás

- Csoport identitás: jelentések egy csoportja, amely az egyén tagsági csoportjaihoz kötődik, például WWF aktivista identitás

- Személyes identitás: amely egyedi módon önmagára tekint az egyén, mint például etikus személy identitás.

Az identitáselmélet központi megállapítása, hogy az egyének keresik és alakítják azokat a társas szituációkat, amelyekben az identitásaikat igazolni tudják (Burke és Stets, 2009). Ezek az identitás- megerősítési helyzetek azok, amelyek fenntartják az ént. Ezzel egyszerre a viselkedések, amelyek az információ és a jelentések áramlását segítik, a társas struktúra kialakításához és fenntartásához vezetnek, amelybe az identitás tartozik. Ezek a viselkedések megváltoztatják a szituációkat és új identitás-megerősítő megfigyelésekhez vezethetnek (Burke és Stets, 1999). Az identitás megerösítés során az egyének azt vizsgálják, hogy a szituációban mások ugyanúgy látják-e őket, mint ahogy ők önmagukat (Burke és Stets, 2009). Amikor egy identitás aktiválódik egy visszacsatolási hurok alakul ki, amely során az egyén az identitás sztenderd jelentéseivel hasonlítja össze az által észlelt és a mások visszajelzése által kapott jelentéseket. Attól függően, hogy az input jelentések és az identitás sztenderd jelentései között milyen mértékü a megfelelés, eltérő érzelmek jelentkezhetnek az egyénben. Ha egyezés van a jelentések között, pozitív érzelmet él át az egyén, mint boldogság vagy büszkeség, amennyiben eltérés merül fel, negatív érzelmek, mint depresszió vagy stressz érzés alakulhat ki (Burke és Stets, 1999). Ez a folyamat alapvetően tudattalanul zajlik. Az identitás sztenderdek irányítják az egyén viselkedését azáltal, hogy hozzá illő kimeneteket valósítanak meg, illetve, ha nem áll fenn egyezőség az identitás sztenderdek és az aktív identitás között, akkor a viselkedést úgy próbálja megváltoztatni az egyén, hogy igazodjon (Stets és Serpe, 2013). Az önmagukat dominánsnak tartó személyek hajlamosak például még határozottabban viselkedni, ha olyan visszajelzést kapnak a viselkedésükre, hogy engedelmesen viselkednek (Swann és Hill, 1982).

Az identitás szerep-, szituációfüggősége miatt természetesen egy egyénnek több identitása is van. Az eltérő identitások hierarchikusan rendeződnek el (Burke és Stets, 2009), az egyének egy én-struktúrát alakítanak ki, amely rendszerezi az eltérő identitásokat. Ezt jeleníti meg az identitás kiemelkedősége, amely azt mutatja meg, hogy milyen valószínűséggel idézi fel az egyén az adott identitást a különböző szituációkban. 
A kiemelkedő identitások gyakrabban jelennek meg akár verbálisan, akár viselkedéses megnyilvánulás formájában. Az identitás kiemelkedőségét a viselkedés indikátorának tekintik, amely a társas cselekvésekben való ágens jellegét mutatja az identitásnak (Stryker és Burke, 2000). Az identitások kiemelkedősége alapján alakul ki a hierarchia és Stryker szerint az egyének aktívan keresik is azokat a szituációkat, amelyben a kiemelkedő fontosságú identitást aktiválni tudják (Stryker, [1980] 2002 idézi: Stets és Serpe, 2013). Az egyén elköteleződése határozza meg, hogy mennyire válik az identitás kiugróvá. Az elköteleződés behozza a társas struktúra szerepét, mert ez mutatja meg, hogy az egyén mely társas hálózatoknak a tagja (Burke és Reitzes, 1991). Az elköteleződés azt is mutatja, hogy az egyén milyen keményen dolgozik az identitásának megerősítésén. Minél komolyabban foglalkozik az identitás megerősítésén, annál elkötelezettebb az identitás felé.

Az én-fogalom szerveződését vizsgálva ki kell emelni az identitás központiságát, amely azt jelzi, hogy az identitás mennyire fontos az egyén számára. Minél fontosabb, annál inkább középen helyezkedik ez az én-fogalmában (Stets és Serpe, 2013). Az identitás fontossága függ attól, (1) hogy mások mennyire támogatják az adott identitás az egyénben, attól, (2) hogy mennyire elkötelezettek az identitás iránt, és attól is, hogy (3) kapnak-e jutalmat az egyének, akár külső, akár belső megerősítést. A központiság hasonlónak tünik a kiemelkedőség fogalmához, a fö különbségtétel az, hogy a kiemelkedőség a lehetséges magatartáson alapul, míg a központiság a belsővé tett fontosságán az identitásnak (Stryker és Serpe, 1994).

Az elmélet foglalkozik az identitás-változás lehetőségeivel is, amellett, hogy hangsúlyozza a tartósságát és azt, hogy az identitás megváltozásához hosszabb idő szükséges. Az identitás-változást Burke (2006) három okra vezeti vissza (Burke, 2006):

- a szituáció változik meg, amely változást okoz az identitás jelentésekben. Egy gyermek születése például nem csak a szülői identitást aktiválja, hanem a nemi identitásban is változást okoz, a kutatások azt mutatják, hogy a férfi identitás maszkulinabb, míg a női identitás femininebbé válik (Burke és Cast, 1997).

- több identitás aktiválódik egy helyzetben és az identitások konfliktusba kerülnek, ami mindegyik identitásban változást okoz. Ilyen esetben általában a két identitás elkezd közelíteni egymáshoz és egy köztes állapotban áll meg. A női identitás például konfliktusba kerülhet a munkahelyi vezetői identitással, amely hatására lassan kiegyenlítődnek a jelentések menti eltérések (Burke és Stets, 2009). Az 
identitások azonban változó mértékben alakulhatnak át, várhatóan a kevésbé kiemelkedő és a kevésbé központi identitás fog kisebb változást mutatni, míg a kevésbé elkötelezett identitás több változáson esik át.

- identitás jelentések és a viselkedés jelentések kerülnek konfliktusba, amely változást okoz a jelentésekben. Ahogy említettem, az egyén az identitás jelentésnek megfelelő cselekvéseket igyekszik végezni adott szituációban, és olyan alternatív viselkedést alakít ki, amely illeszkedik az identitáshoz. Ilyen esetekben (ha nem aktiválódik más identitás) lassan az identitáshoz kötődő jelentések is megváltoznak hogy a viselkedés közti konzisztencia kialakuljon (Burke, 2006).

\subsection{TÁRSAS IDENTITÁS ELMÉLET}

A marketing tudományterületén a személyiségelméletek közül a szimbolikus interakcionizmus társadalmilag meghatározott én-fogalmához hasonlóan a társadalomnak nagy hangsúlyt adó, a csoportközi kapcsolatokat, csoportfolyamatot és társas identitást központba állító Társas (Szociális) Identitás Elmélet a legelterjedtebben használt megközelítés. Ez az elmélet is a szociálpszichológia kutatásain alapul (Reed, 2002).

Tajfel elméletének alapját a sztereotípia és a diszkrimináció kutatása adta; a csoportviselkedést vizsgáló kutatások eredményeinek az értelmezésére és magyarázatára készült a szociális identitás elmélet (Oakes és tsai., 1999). Tajfel szerint a társas interakciókban a szociális kategorizáció lehetővé teszi az egyén számára a társas környezet oksági megértését, valamint meghatározza az egyén helyét a társadalomban. A társas kategorizáció és az én közötti kapcsolatot nevezte Tajfel szociális (társas) identitásnak (Tajfel, 1978). A társas identitás ,az egyén énképének az a része, ami az ő társadalmi csoportban (vagy csoportokban) való tagságának ismeretéből származik, valamint a tagsághoz füződő értékből és ennek emocionális jelentőségéből” (Tajfel, 1978, 63. o., idézi: Oakes és mtsai., 1999).

A társas kategória lehet például nemzetiség, politikai hovatartozás, sportcsapat, stb., amelyhez tartozónak érezzük magunkat, és amelynek jellemzői az én-fogalomban is megjelennek (Hogg és tsai., 1995). Egy énen belüli szociális kategória-tagság egy, a 
kategóriával összeillő énképet eredményez, amely az én-fogalom részévé válik (Reed, 2002). Az önmeghatározást tehát befolyásolja a csoporttagság. Az önmeghatározás lényege az egyén én-fogalmának az a része, amely a társas csoporttagságból származó tudásból, értékekből és érzelmek összekapcsolódásából a csoporttagsághoz kötődik (Tajfel, 1981 idézi: Reed, 2002).

Az egyén teljes repertoárral bír a kategória tagságokból, amelyek fontosságuk alapján változtatják helyzetüket az én-fogalomban. Ezek a tagságok társas identitásként jelennek meg, és meghatározzák az attitüdöket, hogyan kell gondolkozni, érezni és viselkedni a csoport tagjaként. Ha egy adott társas identitás kiemelkedik és az önszabályozás alapjává válik az adott kontextusban, akkor kialakul a saját csoport és a külső csoporttal kapcsolatos sztereotípia. A társas identitás nemcsak leíró és elöíró, hanem értékelő is. Mivel a társas identitásnak fontos önértékelési következményei vannak, ezért a csoportok és a tagok erősen motiváltak az elvárt viselkedési stratégiák követésére, hogy elérjék és fenntartsák a saját csoport és önmaguk pozitív értékelését.

A társas identitás elmélet két szocio-kognitív folyamatot is alkalmaz (Hogg és tsai., 1995):

- Kategorizáció: a társas kategória társas referenciakeretként szolgál az egyéni viselkedések interpretációjához (Oakes és tsai., 1999), élesebbé teszi a saját csoport határait azzal, hogy kiemeli a csoport-megkülönböztető sztereotip és normatív észleléseket és cselekvéseket, és így az egyéneket a környezettől függő megfelelő kategóriákba helyezi (Hogg és tsai., 1995). A kategorizáció alapvető kognitív folyamat.

- Ön-becsülés (self-enhancement): feltételezi, hogy az egyén alapvető szükséglete a fontos személyektől származó pozitív értékelés. Az önbecsülést el lehet érni azzal, ha a saját csoport és a külső csoport összehasonlításában a saját csoportot helyezzük előtérbe.

A saját csoport előnyben részesítése (Oakes és mtsai., 1999, 448. old.) függ attól, hogy:

- mennyire azonosul az egyén a saját csoporttal;

- mennyire kiemelkedő jellemző a szociális kategorizáció az adott helyzetben;

- mennyire jelentős az összehasonlító dimenzió;

- összehasonlíthatók-e a csoportok az adott dimenzió mentén;

- milyen a saját csoport relatív státusza. 
A társas identitás elmélete és kutatása a megkülönböztetési folyamat árnyaltságát és érzékenységét hangsúlyozta a társas kontextus illetve a csoportközi kapcsolatok irányában (Oakes és tsai., 1999).

\section{Önkategorizációs elmélet}

Turner az önsztereotipizálás hipotézissel elkezdte átdolgozni a szociális identitás elméletét a pszichológiai csoport egy kognitív elméletévé. A szociális kategorizáció ugyanis az egyénben önsztereotipizálást okoz. Az önsztereotipizálás elszemélytelenedést okoz, azaz adott csoportban az egyének bizonyos dimenziók mentén perceptuálisan felcserélhetőek lesznek, úgy reagálnak, viselkednek, mint a saját csoport megtestesítői, és nem mint egyedi személyek (Hogg és tsai., 1995). Az énnek ez az újradefiniálása közvetíti a csoportviselkedést, de nem jelenti az identitás elvesztését. Turner szerint a szociális identitás a self szociális kategorizációinak sürítése, ami a csoportjelenségeket idézi elő. Ez a felfogás jelentősen eltér Tajfel szociális identitás koncepciójától, ami a csoport-hovatartozást jelenti (Oakes és tsai., 1999).

Ez alapján az eltérés alapján építette fel Turner az önkategorizációs elméletet. Eredeti célja a szociális csoportok pszichológiai alapjainak magyarázata volt, de valójában egyaránt szól az egyéni identitásról és a csoportjelenségekről is. A személyes és a szociális, az egyén és a csoport egymás közti kapcsolatával foglalkozik. A csoport bár különálló pszichológiai folyamat, a csoportmüködés az egyén pszichológiájának a része (Oakes és mtsai., 1999).

Az identitás külső, társadalmi meghatározottságát hangsúlyozó elméletek felrajzolják az individualizáció mellett az azonosulás lehetőségét és fontosságát is. A pozitív önértékelés kialakítása és fenntartása érdekében kiemelt jelentőségü, hogy a jelentős hatással bíró mások, csoportok pozitívan értékeljék az egyént.

A pszichológiai személyiség elméletek, ahogyan a fenti bemutatásból is látszik, alapvetően az ember társas létének az identitásra gyakorolt hatásait hangsúlyozzák. Az egyén humán, azaz társas környezetét tekintik az egyén identitását meghatározó jelentős elemnek és hajlamosak a nem emberi, a természeti környezet (állatok, növények, hegyek, azaz a teljes természet) identitásformáló hatásától eltekinteni. A természet is része lehet az egyén identitás formálásának, abban az esetben, ha az egyén a természettel, mint a környezetének elemével azonosul. A kialakult identitás - ugyanúgy, mint a 
csoportidentitás esetében - az egyént a természetet védő viselkedések kialakítására fogja ösztönözni a pozitív én-értékelés kialakítása érdekében. Ez a kapcsolat határozható meg a környezeti identitás koncepciójával.

A disszertáció első négy fejezetének a célja a kutatási téma kontextusba helyezése volt. Bemutattam, hogy az egyén személyes jellemzői hogyan jelenhetnek meg a fenntarthatóság, valamint a környezetbarát viselkedés keretrendszerében, majd értelmeztem a környezetbarát viselkedést és a személyiséget a pszichológia különböző irányvonalai között, kiemelve a környezeti identitás fogalmának értelmezéséhez szükséges legfontosabb elméleti kereteket. A disszertációm további fejezeteiben a környezeti identitás fogalmának, jelentőségének és mérési lehetőségeinek a megismertetésére törekszem. 


\section{IDENTITÁS ÉS TERMÉSZET}

Az én-fogalom és az identitás értelmezése esetén fennálló átfedések és fogalmi eltérések (szelf, én, én-fogalom, stb.) önkényes használata (Leary, 2007) ugyanígy jellemző, ha az ember a természetről gondolkozik. Mindenkinek él egy kép a fejében arról, hogy mi a természet, a meghatározása azonban mégis komplex és vitatott (Clayton és Opotow, 2003).

Fontos leszögezni, hogy a természet fogalma egy társadalmi konstrukció - amely sok mindent jelenthet, a Földet, a csillagokat, az állatokat - egy ember által alkotott fogalom, amely kultúrafüggő, ezért személyenként változhat az értelmezése. Az egyén és a természet kapcsolatát emiatt számos kutató eltérően értelmezi és elemzi.

Általánosnak tekinthető az a definíció, hogy a természet a minket körülvevő „,nem ember által alkotott környezet” (Simmons, 1993, 11. old.). Ez felveti azonban azt a gondolatot, mi is az a környezet napjainkban, amelyhez az ember még nem nyúlt hozzá, nem módosított valamilyen szinten? McKibben (1989, idézi: Clayton és Opotow, 2003)

provokatív gondolata szerint az időjárás ember okozta változásai miatt a Földön már minden területet mesterségessé tett az ember.

Az ember és a környezet kapcsolatával számos tudományterület foglalkozik, mint például a filozófia, pszichológia, biológia, ökológia. A biológus Wilson szerint, az embereknek egyenesen genetikailag fontos a természettel való kapcsolat, szükséges a természeti környezet megtapasztalása. Wilson (1984) ezt az igényt biofíliának nevezte. Az emberi viselkedés ilyen genetikai alapon való meghatározottságát azonban nehéz bizonyítani és sokan vitatják.

Aldo Leopold, nagyhatású ökológus, az ember és a környezet viszonyát az etika és az esztétika fogalmak keretében elemezte (Leopold, 2004). „Csak úgy viselkedhetünk etikusan valami irányában, ha láthatjuk, érezhetjük, megérthetjük, szerethetjük vagy valahogyan másképp hiszünk benne” (Leopold, 1949, idézi: Leopold, 2004). Leopold fogalmazta meg először a „megőrzés etikáját”, az emberek etikai felelősségét a természet iránt. Leopold szerint (1949, idézi: Mayer és Frantz, 2004) azért bánunk rosszul a természettel, mert egy árucikknek tekintjük, amelyet megvásároltunk, a miénk. Ha a Földet, mint egy közösséget látnánk, amelyhez tartozunk, akkor megtanulnánk tisztelni 
és szeretni azt. Rachel Carson is ezt az etikai hozzáállást erősíti meg jelentős művében, a Néma Tavaszban, amikor amellett tanúskodik, hogy az embereknek nem elég az emberekért aggódniuk, hanem hangsúlyozza az összes élőlénnyel való kapcsolat fontosságát (Carson, 1962).

A mélyökológia filozófiai irányzata a természet önmagában való értékét, a létezők egyenjogúságát és egymásrautaltságát állítja előtérbe. Képviselői elvetik az emberközpontú perspektívát, és biocentrikus alapra helyezik az etikai kérdéseket is (Leopold, 2004). A kiegyensúlyozott élethez a természettel való mély és személyes kapcsolat elengedhetetlen (Clayton, 2003). Fő képviselője Arne Naess norvég filozófus az ökológiai válságot egy önmagával meghasonlott emberiséggel indokolja (Naess, 2005), amely azt a téves eszmét vallja, hogy az önérvényesítés csak mások rovására történhet. A környezetvédelem során sem áldozathozatalról kell beszélni, hiszen akkor vagyunk leginkább önmagunk, amikor egy közösség részeként egymást támogatva, segítve élünk (Lányi, 2007). A tudatosult lét ugyanis nem elkülönülést jelent, hanem éppen ellenkezőleg, azonosulást, bensőséges együttlétet más létezőkkel (Naess, 2005). Ennek eredményeként az antropocentrikus világképből a biocentrikus világképre való átváltás folyamatosan alakult át az ökológia és az öko-filozófia területén.

A környezeti pszichológia terápiás módszere pedig kifejezetten az egyén természettel való kapcsolatának megismerésére fókuszál, a teljes mentális egészség elérése érdekében. Az ember és a környezet kapcsolatának több elönye van:

- A környezet gyógyító közeg (Kaplan, 1995):

○ fizikai egészséget biztosít,

○ érzelmi, pszichológiai hatásai vannak, mint a nyugalom, önbizalom, kíváncsiság erősítése.

- Lehetőséget ad önreflexióra (Herzog és tsai., 1997), van idő és hely gondolkodni értékeinken, céljainkon. Jobban megismerhetjük önmagunkat, lehetőségeinket, képességeinket, azáltal, hogy az ok-okozati kapcsolatok a természeti környezetben egyértelmüek, ellentétben a társas, társadalmi kapcsolatokkal (Clayton, 2003).

A környezeti pszichológia Leopold gondolatait is visszatükrözi, amikor a természethez való tartozás érzésének fontosságát, mint a környezetvédelem előfeltételét hangsúlyozza. Ha az én fogalmát kiterjesztjük a természeti világra, akkor azokat a viselkedéseket, 
amelyek a természet pusztításához vezetnek, önpusztító viselkedésekként éljük meg (Mayer és Frantz, 2004).

\subsection{KÖRNYEZETI IDENTITÁS}

A környezethez való kötődés, elköteleződés érzését a személyiség, az identitás kialakításában fontos tényezőnek tekinthető. Számos kutató definiálta a környezet és az egyén kapcsolatát az én, az identitás elméleti koncepciójában (Bragg, 1996; Cantrill és Senecah, 2001; Clayton, 2003; Thomashow, 1995).

Disszertációmban azért foglalkozom a környezeti identitás koncepciójával, mert a viselkedéssel való kapcsolata több oldalról bizonyítható:

- a környezeti identitás, mint szociális identitás alakítja, irányítja, értelmessé teszi a társas interakciókat, a környezeti identitás is alapvető fontosságú az ember és környezet között kialakuló értelmes interakció formálásához (Zavestoski, 2003).

- az én-fogalom része az egyén értéke és attitüdje. Az értékek és attitüdök viselkedésre gyakorolt hatásával a kutatások régóta foglalkoznak, és relevanciájukat igazolták (Homer és Kahle, 1988; Kraus, 1995). Következésképpen a személyiség viselkedésre gyakorolt hatása is feltételezhető és vizsgálható.

- az eddigi kutatások fókuszában álló attitűd nem elég erős előrejelzője a valós viselkedésnek, csak a viselkedési szándéknak (Bamberg és Möser, 2007; Csutora, 2012; McBroom és Reed, 1992).

- a környezetbarát cselekvések általában nem a saját hasznosság növelésére irányulnak, hanem morális elégedettség elérésére (Clayton, 2003).

- az identitás motivációs rendszerként is felfogható, hiszen viselkedés és cselekvés fölött álló, szervező-orientáló rendeltetése is van (Pataki, 2008). Ez figyelhető meg például a személy viselkedésének a legkülönbözőbb élethelyzeteken keresztül is megnyilvánuló következetességében is. Így az identitás lehetővé teszi a várható viselkedés bejóslását (Stryker és Burke, 2000), az azonos identitással rendelkezők viselkedésének előrevetítését (Zavestoski, 2003).

A fogalom konceptualizálása során eltérő elnevezésekkel hivatkoznak a szerzők a természethez kötődő identitásra. A kutatók egy része az ökológiai identitás (ecological 
identity) elnevezést részesíti előnyben, mert az jobban kifejezi, hogy az én része az ökoszisztémának és elkerüli azt a félreértést, hogy a környezet (environment) fogalom értelmezésébe beletartozik az épített és a társas környezet is. A környezeti identitás elnevezést támogatók azzal érvelnek, hogy ez az elnevezés intuitívabb és könnyebben érthető általában az emberek számára (Clayton és Opotow, 2003).

Disszertációmban egységesen a környezeti identitás elnevezést alkalmazom, mert a hazai általános szóhasználatban a környezetvédelem kapcsán jellemzően a környezeti tudatosság, környezetbarát termék, stb. megfogalmazások használatosak és csak elvétve találkozik az átlag fogyasztó az ökológia szót használó fogalmakkal.

Thomashow (1995) meghatározása alapján az ökológiai identitás (ecological identity) azokra „a lehetséges módozatokra vonatkozik, ahogyan a személyek megkonstruálják magukat a természeti környezettel összefüggésben, ami a személyiségben, értékekben, viselkedésben és az én-élményben válik kézzelfoghatóvá.” (Thomashow, 1995, 3. old.). A természet az azonosulás alapjává válik.

Thomashow a környezeti nevelés irányából közelíti meg az ökológiai identitást, amely értelmezésében is visszatükröződik, amikor hangsúlyozza, hogy az ökológiai identitás kialakulásában az élettapasztalatok értelmezése meghaladja a társas és kulturális interakciók jelentőségét (Thomashow, 1995). Az ökológiai identitás kialakulása véleménye szerint egyéni utakon történik, amit a személyek kognitív, intuitív és érzelmi érzékelése tükröz vissza.

Zavestoski megfogalmazásában, aki a mélyökológia gyökereiből alapozta meg kutatásait (Zavestoski, 2003), az ökológiai identitás (ecological identity) „az énnek azon része, amely lehetővé teszi a személy számára, hogy előrejelezze a természet reakcióit az egyén cselekvéseire" (Zavestoski, 2003, 299 old.). Kialakulásával kapcsolatban Thomashowhoz hasonlóan az egyéni tapasztalatokat hangsúlyozza. Bár a szerző a természet és az ember interakcióit helyezi fókuszba, a visszajelzések fontosságának hangsúlyozásakor a társas visszajelzések fontosságát emeli ki, hiszen a környezet nem tud mindenki számára társadalmilag érthető módon reagálni az emberi cselekvésre. A természet közvetetten és késleltetve reagál az emberi tevékenységre, de visszajelzései, amelyeket például a levegő és vízszennyezésre ad, az emberi egészségre is káros hatással van. A közvetett hatás következtében azonban a társas környezet visszajelzéseit is figyelembe kell venni a témakör elemzése során, mert az adott visszajelzések a természet és az ember interakciót 
is meghatározzák, és validálják az ökológiai identitás által irányított cselekvéseinket. Az ökológiai identitás cselekvést befolyásoló ereje tehát nagyrészt a többi társas identitásunkkal való kapcsolaton nyugszik. Ezért fontos, hogy a társas környezetünk számára se legyen pozitív társas jelentése a környezetre káros viselkedésformáknak.

Az identitás társadalmi szerepeket határoz meg, és a szerepekhez felelősségek kapcsolódnak. Clayton (2003) környezeti identitás koncepciójának az értelmezésében is fontos szerepet kap a társas befolyás, hiszen önmagunk természetben való értelmezését áthatja kulturálisan meghatározott megértésünk a természetről, annak értékeiről és használatáról (Clayton és Opotow, 2003). A környezeti identitás értelmezésekor a társas hatás alatt azonban nem az emberi csoportok hatását kell hangsúlyozni, hanem a természet, mint társas közeg jelentőségét.

A környezeti identitás megmagyarázza, hogy az absztrakt globális problémák hogyan válhatnak közvetlen és személyes problémává (Clayton és Opotow, 2003). Clayton környezeti identitás koncepciója az emberek által az élőlényeknek tulajdonított jogok, a környezeti igazságosság kutatásaiból indult ki. Az ökológiai döntések és a környezeti identitás vizsgálatára vonatkozó kutatásaik (Opotow és Clayton, 1994) alapján az ember és a természet kapcsolata összhangban van az egyének az irányú értékelésével, mennyire tartják az emberi fajt felsőbbrendűnek a növényekhez és az állatokhoz képest, és hogy azonos jogokat tulajdonítanak-e nekik, mint az embereknek.

Clayton (2003) felfogásában a környezeti identitás az alábbiakban ragadható meg: „A környezeti identitás az egyének énkép formálásának egy része, a természettel való kapcsolat érzése, amely a múlton, az érzelmi kötődésen és azokon a hasonlóságokon alapul, amelyek meghatározzák, hogyan észleljük a világot és hogyan viselkedünk benne, illetve az a hit, hogy a természet fontos része annak, akik vagyunk." (Clayton, 2003, 4546 old.)

A társas hatások alakítják azt, hogyan figyelünk a természetre és hogyan értelmezzük, amit látunk, tapasztalunk. Bár a társadalmi befolyás vitathatatlan, a társas kapcsolatok, az eltérő társas identitások hatásának erőssége eltérő lehet. Abban az esetben, ha a környezeti identitást gyengén befolyásolják a lehetséges társas hatások, az egyének úgy érzik, hogy közvetlenül, társas közvetítés nélkül tapasztalják és értik meg a természetet (Clayton és Opotow, 2003). Az olyan környezeti identitás esetében, ahol magas a társas befolyás, az egyének és a csoportok olyan szociális kategóriákban jelennek meg, ahol az 
aktivizmus és a társadalmi érdekellentétek jelentősek. A környezeti identitás értelmezése tehát nem lehet statikus, hanem a környezet és a társadalom dinamikus kölcsönhatásán alapul.

A környezeti identitás - hasonlóan a nemzeti és etnikai identitáshoz - kollektív identitásnak tekinthető. Azt az érzést nyújtja számunkra, hogy egy nagyobb egység részei vagyunk, észrevesszük a hasonlóságot magunk és mások között (Clayton, 2003). Mint minden csoport-identitásnak, a környezeti identitásnak az erőssége is egyénenként változhat, ami befolyásolja az egyéni identitásra, viselkedésre gyakorolt hatását. Disszertációm kutatási fázisaiban minden esetben kiemelt fókuszt kap a környezeti identitás viselkedésre gyakorolt hatása.

\subsection{A KÖRNYEZETI IDENTITÁS KIALAKULÁSA ${ }^{13}$}

A környezeti érzékenység, a környezetbarát magatartás iránti fogékonyság és elköteleződés kialakulásának az életeseményeken keresztüli vizsgálata az 1980-as években került a kutatások fókuszába (Tanner, 1980). Ezt követően kvantitatív és kvalitatív módszerekkel is vizsgálták a környezeti érzékenység alakító tényezőit (Chawla, 1998). Ezek a kutatások összehasonlításra nem alkalmasak az eltérő minták és módszertan miatt, azonban az eredmények nagymértékü átfedést mutatnak a kiemelt eseményeket tekintve. A vizsgált kutatások mindegyikében megjelentek az olyan föbb élmények, események, mint a természetben szerzett élmények, vagy a példaértékű személyek és az oktatás.

A természetben szerzett élmények (egyes megfogalmazásokban outdoors) a leggyakrabban megjelent tényezők (Chawla, 1998, 1999; Palmer, 1993; Tanner, 1980). Ezen belül a kutatások kiemelik a gyermekkori élmények szerepét, amelyek lehetnek családi nyaralások, vagy ifjúsági táborok, szabadtéri tevékenységek. Palmer eredményeiből azt a következtetést szürte le, hogy a „szabadtéri gyermekkori élmények a legfontosabb tényezői a természet iránti aggodalom kialakulásának” (Palmer, 1993, p. 29). Ezt a kijelentés erősen túlhangsúlyozza a gyermekkori élményeket, amely nem bizonyított, hogy a legfontosabb befolyásoló erő lehet, hazai kutatásokban alacsonyabb

\footnotetext{
${ }^{13}$ A fejezet megjelent cikk részletként (Hofmeister-Tóth és tsai., 2012a)
} 
jelentőséget kapott (Hofmeister-Tóth és tsai., 2012a), de a szerepük mindenképp kiemelt az életesemények vizsgálatában.

A szerepmodellek - kiemelten a család és egyéb rokonok - hatását is általánosan visszaigazolják a kutatások, valamint hangsúlyozzák az oktatás szerepét. Az oktatás esetében a szakirodalom általában külön kategóriaként kezeli a tanárokat és magát az oktatást, mint intézményt (Chawla, 1998). Az oktatás mellett az egyéb szervezetek, mint a környezetvédő szervezetek, civil szervezetek szerepét is ki kell emelni (Gunderson, 1989, idézi: Chawla, 1998; Chawla, 1999).

A negatív tapasztalatok mint befolyásoló tényezők megjelentek a későbbi kutatásokban (Chawla, 1999; Palmer, 1993; Palmer és Suggate, 1996); ez alatt az észlelt környezetszennyezést, a környezetrombolást, környezeti katasztrófákat értjük. Emellett nem egységesen, de több elemzésben is megjelent az utazások és a külföldön szerzett tapasztalatok (Palmer, 1993; Tanner, 1980), valamint a vallás, a spiritualitás és a személyiség szerepe.

Chawla (1999) vizsgálata során azt is felmérte, hogy az adott életesemények mely életfázisban vannak a legnagyobb hatással. A természeti környezetben szerzett tapasztalatok, a családtagok és az oktatás egyértelmüen a gyermekkorban játszanak kiemelt szerepet. Ezeket az eredményeket hazai kutatások is alátámasztják (HofmeisterTóth és tsai., 2012a), kiegészítve a hit és a vallás lehetséges pozitív hatásaival. Az egyetemi évek alatt a barátok és szintén az oktatás hatása válik intenzívebbé. Felnőttkorban a szervezetek, közösségek befolyásoló szerepe válik előmozdító tényezővé.

\subsection{IDENTITÁS MÉRÉSEK}

A környezet és az ember kapcsolatának mérésére négy jellemző skála és módszer használata vált kiemelkedővé az elmúlt években. A különbségek egyrészt abban nyilvánulnak meg, hogy a környezet és a természet mely dimenziójára fókuszálnak a megközelítések (Brügger és tsai., 2011) - Mayer és Frantz skálája az érzelmi kötődést vizsgálja, Clayton a természet szerepére fókuszál a személyes identitásban -, másrészt abban, hogy explicit vagy implicit mérésről van-e szó, azaz a környezet és egyén közötti kapcsolatot tudatos, vagy tudattalan jelenségnek feltételezi. 
Schultz 2001-es A környezet személyiségbe illesztése (Inclusion of nature in the self, INS) elnevezésű skálája (Schultz, 2001) - amely Aron és mtsai 1992-es skálájának adaptálása - az implicit mérések közé tartozik. Később Schultz és munkatársai (2004) a természet és egyén kapcsolatának vizsgálatára alkalmazták az Implicit Asszociációs Teszt koncepciót (Implicit Association Test - Nature).

Gyakran alkalmazott mérőeszköz Mayer és Frantz 2004-es Természethez való kötődés skálája (Connectedness to nature scale, CNS) is, amelynek eredeti célja a kötődésvizsgálat kiegészítése az érzelmi komponenssel (Mayer és Frantz, 2004).

\subsubsection{A KÖRNYEZETI IDENTITÁS MÉRÉSE}

Disszertációmban Clayton (2003) Environmental Identity skálájának vizsgálatát helyezem a középpontba. A Környezeti Identitás Skála (EID) egy széles identitás koncepciót vizsgál. Tartalmazza az érzelmi asszociációk mérését a környezettel szemben, valamint a természetvédő irányvonalakkal való egyetértést és a természettel való interakció mértékét is (Gosling és Williams, 2010). A skálának tehát van érzelmi, kognitív és viselkedésre vonatkozó dimenziója is.

A skála célja, hogy meghatározza, milyen mértékben játszik szerepet a természeti környezet az egyének ön-definiálásában. A skála dimenziói a kollektív társadalmi identitást meghatározó faktorokon alapulnak, amelyek a következők: az identitás kiemelkedő vonásai ${ }^{14}$, azonosulás a csoporttal, a csoporttal összekapcsolt ideológia, és a csoporttal szembeni pozitív érzelmek. A dimenziók operacionalizálása a következőképpen történt:

- a vonás kiemelkedősége: a természettel való kapcsolat fontossága. Skála állitás: Sok idöt töltök természeti környezetben (erdö, hegyvidék, puszta, tópart, tengerpart).

- azonosulás: a természet hogyan járul hozzá a közösséghez, amellyel az egyén azonosul. Skála állítás: Úgy tekintek magamra, mint aki a természet része, nem független töle.

- ideológia: a környezeti oktatás és a fenntartható életmód támogatásának mértéke.

Skála állitás: A Földdel szembeni felelösségteljes viselkedés, azaz a fenntartható életmód követése része az erkölcsi kódexemnek.

${ }^{14}$ salience 
- pozitív érzelmek: a természet által okozott öröm, megelégedettség mértéke Skála állitás: Inkább élnék egy szép kilátással rendelkezö kisebb szobában vagy házban, mint egy olyan szobában, vagy házban, amely nagyobb, de más épületekre néz.

- életrajzi elemek: Skála állitás: Gyermekkoromban sok időt töltöttem a szabadban. Clayton (2003) kiemeli, hogy a skála társas identitást mér, ezért kultúra-, vallás- és világnézet- függő. A skála eredeti verziója 24 állításból áll (lásd: Melléklet), és egydimenziós konstrukció.

A skálát több kutatásban is alkalmazták, amelyek a meglévő mérőeszközök jellemzésére, összehasonlítására vonatkoztak (Brügger és tsai., 2011; Gosling és Williams, 2010; Kiesling és Manning, 2010; Olivos és Aragonés, 2011; Olivos és tsai., 2011). Ezek a kutatások mind magas megbízhatóságról adnak számot (Cronbach alfa értéke 0,9 körüli), de eltérő véleménnyel vannak a skála dimenzionalitásáról. Brügger és munkatársai a skálát faktoranalízissel vizsgálták, ahol két faktort találtak, az egyik a Mayer és Frantz Természethez való kötődés (CNS) skálájához hasonló, érzelmi kötődést kiemelő koncepcióval rendelkezik, míg a másik a NEP skálában használt környezeti aggodalom koncepciót jeleníti meg a szerzők szerint (Brügger és tsai., 2011).

Olivos és Aragonés (2011) főkomponens elemzést végeztek oblimin rotálással, melynek eredményeként négy faktort állapítottak meg, amelyek a teljes variancia 55,6\%-át magyarázták. A faktorok a következőek:

- Környezeti Identitás, amely a Clayton-féle identifikáció, azonosulás tényezővel hozható párhuzamba

- A természet élvezete, amely a Clayton-féle vonás kiemelkedőség tényezőhöz áll közel

- A természet megbecsülése, amely a Clayton-féle pozitív érzelmek tényezőnek felel meg

- Környezetvédelem, amely a Clayton-féle ideológia tényezőhöz hasonlóan a morális értékeket, az ideológiai elköteleződést jelképezi.

Az eltérő eredmények természetesen eredeztethetőek a módszertani különbségekből, illetve a kulturális eltérésekből is.

Clayton kifejlesztett egy rövidített identitás skálát, amely 11 állításból áll (forrás: Clayton, személyes konzultáció). Disszertációmban ezt a skálát alkalmazom, amely 
ugyanannak a koncepciónak a mérése mellett könnyebben érthető a válaszadók számára (Clayton és tsai., 2011).

\subsubsection{TERMÉSZETHEZ VALÓ KÖTÖDÉS}

Pszichológiai szinten annak mértéke, hogy az egyén mennyire asszociálja önmagát a természettel, közvetlen összefüggésben áll az egyén attitüdjével (Schultz és tsai., 2004). Azok a személyek, akik a természeti környezettel összekapcsolják önmagukat, erősebben aggódnak a környezeti problémák miatt. Azok, akik kevésbé kötődnek a környezethez, szintén aggódhatnak a környezeti problémák miatt, de szükebb problémákra fókuszálva, olyanokra, amelyek közvetlenül az egyénre vannak hatással. Ennek az igazolására végzett Schultz kutatásokat, először a kötődés explicit vizsgálatával, majd implicit módon is.

Schultz a környezettel való kapcsolatot pszichológiai változóként kezeli, egyéni szinten vizsgálja (Schultz és tsai., 2004). Ehhez a pszichológiában a társas kapcsolatokra alkalmazott Aron-féle skálát (Inclusion of Other in Self Scale) adaptálta az egyén és a környezet kapcsolatára (Schultz, 2001). Az eredeti skála (Aron és tsai., 1992; Aron és tsai., 1991) mindössze egy állításból áll, amely egymást eltérő mértékben átfedő köröket jelenít meg, amelyből a válaszadónak ki kell választani a kapcsolathoz leginkább illeszkedőt. Schultz interpretálásában az „én” és a „természet” kapcsolatát jelképezik a körök, és 7 körpárból kell kiválasztani a megfelelőt. Ezt a skálát Schultz Természet Énbe Illeszkedése (Inclusion of Nature in Self, INS) skálának nevezte. A kutatások eredményei azt mutatják, hogy az INS skála pozitívan korrelál a bioszférikus aggodalommal, és az önbevallással mért környezetbarát viselkedéssel (Schultz, 2001).

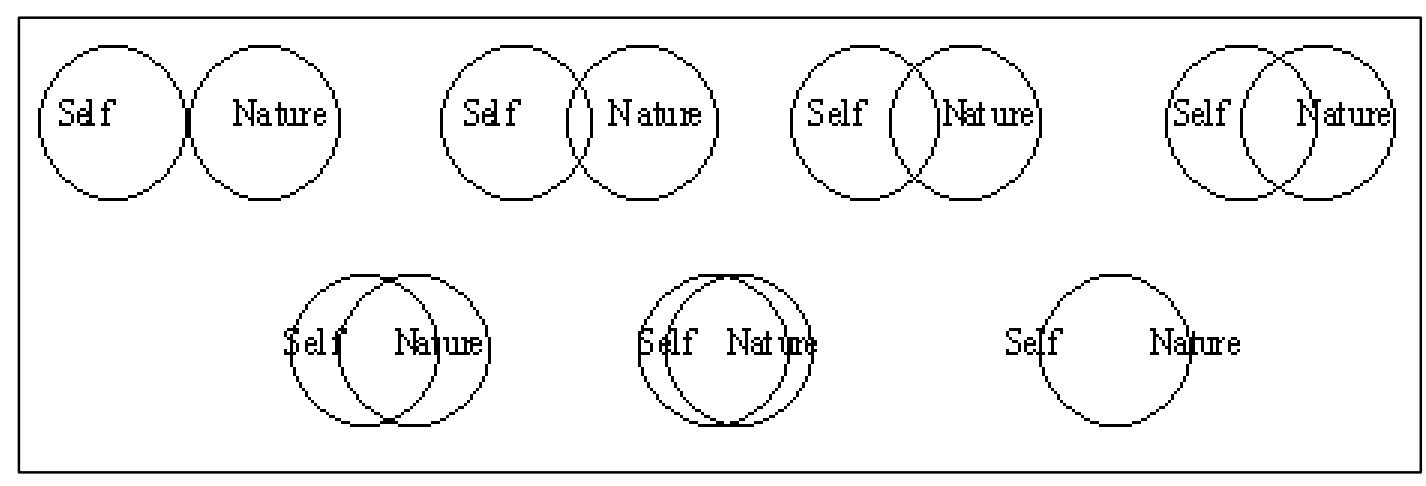

\section{3. ábra: Inclusion of Nature in Self skála}

Forrás: Schultz, 2001 alapján 
A koncepciót és az explicit méréseket azonban több kritika érte, amelyek alapján Schultz is eltérő módszert alkalmazott későbbi kutatásaiban:

- az INS csak egy állításból áll, ami nem teszi lehetővé a belső megbízhatóság vizsgálatát;

- önbevallásos módszeren alapul, amely szükségessé teszi, hogy a válaszadók explicit meggyőződéssel rendelkezzenek az egyén és természet kapcsolatáról. A válaszadók gyakran nem gondolkoznak el előtte erről a kérdésről, és nincs létező hiedelmük a természetről, de képesek válaszolni a kérdésre.

- Dunlap és kollégái (Dunlap és tsai., 2000) szerint az egyén világnézete „primitív” hiedelem, és így a természethez való kötődés nem tudatos, de legalábbis nem olyan hiedelem, amire rendszeresen gondolunk.

Ezekre a kritikákra alapozva Schultz és kollégái kidolgoztak egy alternatív mérési technikának, az Implicit Asszociációs Tesztnek (IAT) a természet és egyén kapcsolatára adaptált változatát (Bruni és Schultz, 2010; Schultz és tsai., 2004; Schultz és Tabanico, 2007), amelyhez nem szükséges az asszociáció tudatossága.

Az önbevalláson alapuló megkérdezés hátránya, hogy tudatos átgondolást igényel, amely elkerülhető az indirekt vizsgálatok során. Az implicit módszerek hasznosak, ha magas a társadalmi megfelelési kényszer, a társadalmi kívánatosság által okozott eltérés, mint például a hiúság, a stigmatizált viselkedések, a drog és alkoholfogyasztás vizsgálata esetén (Perkins és tsai., 2008). Ezeken a területeken az explicit és az implicit attitüd között gyakran eltérés figyelhető meg, mert az implicit mérések esetében nem jelenik meg a megfelelési kényszer hatása, és nehéz „meghamisítani” az eredményeket (Schultz és tsai., 2004). Az eltérések mellett azért az implicit mérések általában pozitív korrelációt mutatnak az explicit mérésekkel is (Greenwald és Banaji, 1995; Greenwald és tsai., 1998; Schultz és tsai., 2004; Schultz és Tabanico, 2007).

\subsubsection{Az Implicit Asszociációs Teszt bemutatása}

Az Implicit Asszociációs Teszt (IAT) a leggyakrabban idézett ${ }^{15}$ indirekt mérőeljárás (Nosek és tsai., 2011). A tesztet (angol nyelvü IAT teszt elérhető a https://implicit.harvard.edu/implicit/takeatest.html oldalon) az emlékezetbeli fogalmak és/vagy tárgyak közötti asszociáció relatív erősségének indirekt mérésére alkalmazzák (Perkins és tsai., 2008). A Greenwald, McGhee és Schwartz (1998) által kifejlesztett

\footnotetext{
${ }^{15} 6282$ implicit mérést alkalmazó cikket elemeztek, amelynek 43,6\%-a alkalmazta az IAT módszert
} 
eljárás a válasz látencián alapul, melyet az attitüdtárgy és az értékelő dimenzió párosításának folyamatában kapunk meg (Somogyi és Bernáth, 2014). A teszt számítógép alapú kategorizációs feladatokból áll, amelyet úgy alakítottak ki, hogy az emlékezetben lévő fogalmak közötti asszociáció relatív erősségét mérje, anélkül, hogy önelemzést kívánna meg, amely az implicit mérés legnagyobb előnye (Schultz és tsai., 2004). A legfőbb korlátja azonban, hogy csak olyan attitüd mérésére ad lehetőséget, amelyet viszonyítani tudunk valamihez (Somogyi és Bernáth, 2014), azaz ahogy a későbbiekben látni fogjuk, nem a természethez kapcsolódó attitüd mérésére ad lehetőséget, hanem a természethez és az épített környezethez való attitüd közti különbséget tudja mérni.

A teszt a reakcióidők alapján méri az asszociáció erősségét a fogalompárok és a jellemzők között. Az alanyok feladata az, hogy minél gyorsabban kapcsolják össze a képernyőn megjelenő elemeket (képek, szavak például százszorszép, lepke) a megfelelő fogalmakkal (pl.: virág vagy bogár). Később a fogalmakat kombinálják (pl.: virág és jó, bogár és rossz). A fogalmak közötti kapcsolat szorosságát a kombinált feladatok esetében megjelenő válaszadási idő különbségével mérik, az összeférhető/kompatibilis (compatible) és az összeférhetetlen/inkompatibilis (incompatible) próbák esetében (Greenwald és tsai., 1998).

Az IAT eredményei azt mutatják, hogy az értékek mérsékelten korrelálnak az explicit attitüd mérésekkel, vagyis az önbevalláson alapuló válaszokkal (Schultz és tsai., 2004). Az implicit attitüd annyiban tér el az explicittől, hogy azok az önelemzéstől mentes múltbeli élmények lenyomatai, amelyek a tárgyakkal kapcsolatos kedvező vagy kedvezőtlen érzéseket, gondolatokat, cselekvéseket mediálják (Greenwald és Banaji, 1995). Az implicit attitüd erősen befolyásolt a tudattalan folyamatok által, hiszen független a tudatos átgondolástól és értékeléstől. Az explicit és implicit attitüdök közti különbséget korábban azzal magyarázták, hogy az implicit és az explicit attitüd teljesen független konstrukció (Greenwald és Banaji, 1995). Később az explicit és az implicit attitüdök szétválását azzal magyarázták, hogy a mérések a memóriában határozottan eltérő, de kapcsolatban álló konstruktumokat érnek el (Perkins és tsai., 2008). Az eredmények értelmezése során azonban kevés cikk fogalmazza meg, mely elméleti kapcsolat keretében értelmezi az explicit és az implicit attitűd méréseket:

- egy közös konstrukció két eltérő mérési lehetősége (egységes-folyamat elmélet, single-rocess theory); 
- két eltérő konstrukciót vizsgálnak az eltér méréssel (kettős-folyamat elmélet, dual -process theory);

- vagy általános kulturális tudást jelent a személyes attitüddel szemben.

A teszt felépítése az alábbi tényezőkből áll (Perkins és tsai., 2008):

- attitüd tárgy vagy célkategória (target concept): lehetnek márkák, például CocaCola és Pepsi

- értékelő dimenziók (attribute): olyan jellemzők, amit a válaszadó össze tud kötni az attitüdtárggyal, például kellemes ízü és kellemetlen ízü

- $\quad$ stimulus elemek: a tipikus darabszám 3 és 6 stimulus elem, például képek, márka logók, szavak, szlogenek.

A teszt általában 5-7 sorozat megkülönböztetési feladatból áll. Ezek között vannak gyakorló feladatok, hogy a válaszadók megtanulják a feladatot, és vannak a valódi teszt feladatok, amelyek a válaszadási idő mérésére szolgálnak (Perkins és tsai. , 2008).

- 1 feladat: a két attitüdtárgyhoz kötődő képek, szavak, egyéb stimulik megkülönböztetése a cél, azaz ezeknek a megfelel attitűdtárgyhoz való kötése. (Nyomja meg a D billentyüt, ha a Coca-Cola-hoz kapcsolódik és a $\mathrm{K}$ billentyüt, ha a Pepsihez.)

- 2 feladat: hasonló az elsőhöz, csak a használni kívánt értékelő tulajdonságokat alkalmazza. (Nyomja meg a D billentyüt, ha a kellemes-hez kapcsolódik és a $\mathrm{K}$ billentyüt, ha a kellemetlenhez.)

- 3 feladat: az előző két feladat kombinációja, az első kombinált feladat. Egy attitüdtárgy egy értékelő attribútummal együttesen kapcsolódik az egyik gombhoz, míg a másik attitủdtárgy a másik értékelő attribútummal kapcsolódik a másik gombhoz. Így a célfogalom mindkét kategóriáját és a tulajdonság kategóriáit is tartalmazza a feladat. (Nyomja meg a D billentyüt, ha a Coca-Colahoz VAGY a kellemeshez kapcsolódik a stimulus, és a K billentyüt, ha a Pepsihez VAGY a kellemetlenhez.)

- 4 feladat: az első feladat megfordítása. (Azaz ha korábban a D billentyüt kellett a Coca-Cola-hoz megnyomni, akkor most a $\mathrm{K}$ billentyüt kell és viszont.)

- 5 feladat: a második, fordított kombinált feladat. Az attitüdtárgyak ebben az esetben azzal az értékelö attribútummal kapcsolódnak össze, amelyikkel kombinálva még nem mérték az asszociáció erősségét. (Azaz ha a 3. feladatnál a 
Coca-Cola és a kellemes volt összekapcsolva, akkor most a Coca-Cola és a kellemetlen lesz és fordítva. )

A fent bemutatott feladatsorrend esetében a 3-as és az 5-ös feladatnál kerül a válasz latencia mérésre. Az értékelő dimenzió és a poláris attitűdtárgyakkal való párosítások közötti válaszgyorsaságnak a különbsége jelzi az implicit attitűd erejének mértékét. A teszt értékelése a válaszadási sebességeken alapul, a kezdeti és a fordított kombinált feladat átlagos válaszadási sebességeinek a különbsége (Perkins és tsai., 2008). A teszt hatás számítását Greenwald és kollégái többször átdolgozták, jelenlegi ajánlásuk a Dmérés (lásd 4. táblázat), az eredmények értékelésére (lásd: Greenwald és tsai., 1998; Greenwald és tsai., 2003a). A mutató a szignáldetekciós elméletben alkalmazott d' mérésen és az átlagok közötti különbségek hatásméretét jelölő Cohen-féle d-értéken alapul (Cohen, 1992; Greenwald és tsai., 2006). Minden résztvevőnek a D-értéke az IAT kétféle (kompatibilis és nem kompatibilis) páros, kombinált feladatában kapott reakcióidők átlagából születik meg. A D-mérés az inger párosítási feladatokban adott átlagos válaszlatenciák (a válaszadás közt eltelt idő) közötti különbség, osztva a két blokk minden feladatának szórásával. Amennyiben a páros feladatokat négyszer (két kompatibilis és két nem kompatibilis) kérdezik meg, a fenti módon kapott két hányadost átlagolva jelenti a D- mérés. Az így számított D-érték -2 és +2 között mozog, az alapján, hogy a válaszadónak melyik feltételt volt könnyebb megtanulni (Somogyi és Bernáth, 2014). Amennyiben a résztvevők számára azonos nehézséget jelentett a feladat, a két blokk során nincs különbség a válaszalatenciákban, a D-érték 0-t vesz fel (Greenwald és tsai., 2003b).

\section{D - érték számítása}

\begin{tabular}{|c|c|}
\hline 1. lépés & 10000 ms-nál hosszabb a reakcióidejü próbák törlése \\
\hline 2. lépés & $\begin{array}{l}\text { Azon személyek törlése, akiknek próbái több mint 10\%-ában rövidebb volt a } \\
\text { reakcióidő } 300 \text { ms-nál }\end{array}$ \\
\hline 3. lépés & Teljes szórás kiszámítása az összes kombinált próba esetében (pooled SD) \\
\hline 4. lépés & Átlag-válaszlatenciák kiszámítása a kombinált feladatok blokkjaira \\
\hline 5. lépés & Átlagok közötti különbségek kiszámítása (példában az 5. blokk átlaga-3. blokk átlaga) \\
\hline 6. lépés & Minden kapott különbség elosztása a hozzá tartozó szórással \\
\hline 7. lépés & $\begin{array}{l}\mathrm{D}=\text { a kapott két hányados átlaga (amennyiben a kombinált feladatokat négyszer } \\
\text { kérdezik meg) }\end{array}$ \\
\hline
\end{tabular}

4. táblázat: D- érték számítása

Forrás: Greenwald és mtsai., 2003, p. 214 alapján 
A kutatások (Bar-Anan és Nosek, 2014; Greenwald és tsai., 1998) felhívják a figyelmet a teszt alkalmazása során előforduló eltérések lehetséges okaira is, például arra, hogy az ingerek bemutatási sorrendjének hatása van az eredményekre. Ennek elkerülésére érdemes a feladatokat randomizálni a válaszadók között.

Az IAT módszert több területen is alkalmazták már, Greenwald és Farnham többek között az önbecsülés mérésére adaptálta és bemutatja, hogyan lehet alkalmazni az egyén társas identitásának a megértésére is (Greenwald és Farnham, 2000). A fogyasztói magatartás kutatási területén is alkalmazták már az implicit asszociációs teszteket. A fogyasztói viselkedés meghatározása esetében az implicit és explicit mérések inkonzisztens eredményeket szültek (Perkins és tsai., 2008). Mind az explicit, mind az implicit mérések megfelelőnek bizonyultak módszertanilag, de a sztereotip és az előítéletes viselkedések esetében az implicit mérések megbízhatóbbak.

A fogyasztói attitüdök vizsgálatára használták már a módszert, például a magas és alacsony kalóriájú ételek értékelése (Maison és tsai., 2001) és a fogyasztói etnocentrizmus (Watson és Wright, 2000) kutatása során. Az IAT teszteket alkalmazták már az én - márka asszociációk vizsgálatára, ahol a vásárlási szándékot, a márka preferenciát és az észlelt márkaelőnyt az implicit mérés megbízhatóan meghatározta. Ez igazolja azt az állítást, hogy egy adott tárgyhoz kötődő én-fogalom asszociációk közvetlenül befolyásolják az attitűd kialakulását és a viselkedést is (Greenwald és Banaji, 1995). Az implicit attitűd hatása a márkaválasztásra időnyomás alatt jelenik meg intenzíven, míg az explicit attitüd akkor van hatással a választásra, ha a vásárlónak van megfelelő ideje választani (Perkins és tsai., 2008). Az eredmények tehát azt mutatják, hogy ha a kognitív erőforrások szűkösek, az egyének döntéseiket az implicit asszociációik alapján hozzák meg, mivel hiányoznak azok a kognitív erőforrások, amelyek a tudatos, megfontolt mérlegeléshez szükségesek.

Ez a koncepció áll a természet és az egyén kapcsolatának a mérésére kialakított IATNature teszt mögött, amely az épített környezetet állítja szembe a természethez való kötődéssel a mérés során. 


\subsubsection{IAT- Nature teszt az egyén és a környezet kapcsolatának vizsgálatára}

Az IAT-Nature teszt implicit módon méri annak mértékét, hogy az egyén mennyire asszociálja a saját énjéhez közelinek a természetet. A tesztben két kategóriát alkalmaztak, az Én - Mások és a Természet - Épített környezet kategóriát (Schultz és tsai., 2004).

Az IAT-Nature felépítése Schultz és munkatársai alapján (Bruni és Schultz, 2010; Schultz és tsai., 2004; Schultz és Tabanico, 2007) a következő:

- attitüd tárgy vagy célkategória: Én (Me) - Nem én (Not Me)

- értékelő dimenziók: Természet (Nature) - Épített környezet (Built)

- stimulus elemek: a természethez: állatok, madarak, növények, bálnák, fák; az épített környezethez: épület, autó, város, gyár, utca; az énhez: én, enyém, engem, önmagam; nem énhez: ez, más, ők, övék. (Ezek a stimulus példák a 2004-es kutatásból valók, a későbbi kutatások során módosították ezeket.)

A válaszadóknak a stimulusokat hozzá kell kapcsolni az adott kategóriákhoz, méghozzá úgy, hogy kategória párokat hoztak létre, egyszer az „én” és a „természet” párosítást a „,nem én” és „épített környezet” párral szemben (kompatibilis párosítás), majd fordítva. Azt, hogy a természetet vagy az épített környezetet érzik közelebb magukhoz a válaszadók, abból állapíthatjuk meg, hogy a kompatibilis párosítás során gyorsabban válaszolnak az alanyok az inkompatibilis párosítással szemben.

Az eredmények pozitív IAT hatást mutattak, azaz a válaszadóknak könnyebb volt a természettel, mint az épített környezettel asszociálni magukat, de érdemes megemlíteni, hogy a válaszadók körülbelül 25\%-a könnyebben asszociált az épített környezettel (Schultz és Tabanico, 2007). Ezeket az eredményeket azonban óvatosan kell értelmezni a szerzők szerint, mert lehet egyrészről a Kellert-féle biofília hipotézis igazolása is, mint az egyének alapvető hajlama, de lehet azzal is indokolni, hogy a válaszadók jobban kedvelik a természetet az épített környezettel szemben, és ez teszi az asszociációt könnyebbé (Schultz és tsai., 2004).

Az IAT-Nature pozitívan korrelált a bioszférikus aggodalommal és negatívan az egoista aggodalommal. Ezen felül az IAT pozitívan korrelált az INS skála eredményeivel, valamint a teszt- újratesztelés megbízhatósága is megfelelő volt. Schultz és munkatársai (2004) az implicit kapcsolatot időben stabilabbnak tartják, mert nem befolyásolja a memória, nem titkolható, nincsen válaszadási torzítás, és kevésbé befolyásolják a mindennapi tapasztalatok. Ez természetesen nem azt jelenti, hogy idővel nem 
változtathatók az implicit kapcsolatok, csak azt, hogy nehezebben befolyásolhatók, mint azok a változók, amelyek explicit méréseken alapulnak.

Schultz és kollégái az IAT-Nature tesztet alkalmazták kísérleti körülményeken kívül is, nemzeti parkokban (Schultz és Tabanico, 2007), illetve online játék formájában (Bruni és Schultz, 2010). Eredményeik a módszer megbízhatóságát igazolják, mivel az eredmények konzekvensek maradtak a mérési környezettöl függetlenül. Azt is kimutatták, hogy a korábbi hipotézissel ellentétben az IAT értékek a tapasztalatok által változhatnak (Schultz és Tabanico, 2007). Ez a természet és az egyén kapcsolatának változtathatóságát hangsúlyozza, amely tovább támogatja a környezet és az egyén kapcsolatának a vizsgálatát. Ha a kapcsolat erősíthető, azáltal a környezetbarát magatartásformák megjelenése is elösegíthető.

Az IAT-Nature tesztnek az explicit mérésekkel tapasztalható korrelációja azt igazolja, hogy bár van társadalmi nyomás ezen a területen, de nem olyan intenzív és jelentősen torzító hatású, mint például a faji elöítélet, vagy a szexista attitüd vizsgálata esetében. Az IAT-Nature online megkérdezése esetében a gyermekek és az aktivisták mintáján nem találtak korrelációt az explicit és az implicit mérés között, amit az eltérő explicit mérőeszközzel és esetleg az explicit és implicit mérés eltérő tárgyával magyaráztak.

\subsubsection{TERMÉSZETHEZ VALÓ ÉRZELMI KÖTÖDÉS}

Az ökopszichológia képviselői a biofília elméletből kiindulva azt hangsúlyozzák, hogy a természeti közösséghez való tartozás érzése a környezetbarát viselkedés előfeltétele (Mayer és Frantz, 2004). Azért nem törődünk megfelelően a természettel, mert egy árucikknek tekintjük. Ha úgy tudunk rá tekinteni, mint a közösségre, amelyben élünk, akkor megtanuljuk szeretni, tisztelni, és megóvni. A Connectedness to Nature (CNS), azaz a Természethez való kapcsolódás skálát arra fejlesztették ki (Mayer és Frantz, 2004), hogy a természethez való érzelmi kötődést vizsgálják. A szerzők az alábbiakban hangsúlyozzák az eltéréseket a többi, az ember és környezet kapcsolatát vizsgáló skáláktól:

- a skála érzelem fókuszú, nem kognitív irányultságú, mint a NEP illetve Schultz INS skálája

- több állításból áll, ezért megbízhatóbb mérőeszköznek tekinthető, az INS-sel szemben 
- könnyebb alkalmazni, mint az IAT mérést, de hasonlóan jól jelzi előre a viselkedést.

A 14 állításból álló skála egydimenziós, és magas belső konzisztenciával rendelkezik (Alpha érték 0,84). A skála a környezetbarát viselkedés elörejelzésére megfelelőnek bizonyult, korrelál a bioszferikus érték orientációval, a fogyasztásellenességgel, a környezetbarát identitással és a környezeti perspektíva átvétellel.

Mayer és Frantz szerint a CNS alkalmas a szituációs tényezők és a személyiségjellemzők hatásainak tesztelésére, amelyek a környezettel való kapcsolatot befolyásolhatják. Arra is alkalmas, hogy azon beavatkozások hatását vizsgálja, amelyek az egyén természettel való kapcsolatának erősödésére irányulnak.

A CNS skála az egyik legtöbbet használt skála az egyén és a környezet érzelmi kapcsolatának a vizsgálatára (lásd: Dutcher és tsai., 2007; Frantz és tsai., 2005; Gosling és Williams, 2010; Mayer és tsai., 2009; Olivos és tsai., 2011; Perrin és Benassi, 2009). Perrin és Benassi elemzése azonban rámutatott, hogy a CNS skála nem érzelmeket mér, hanem kognitív hiedelmeket, hasonlóan a NEP-hez (Perrin és Benassi, 2009). Ezt azzal indokolják, hogy az állítások megfogalmazása nem alkalmas érzelmek előhívására. Annak ellenére, hogy 8 állítás is hasonlóan az „Úgy érzem...” megfogalmazást használja, a szerzők szerint ez kognitív értékelést mér, illetve az egyének hiedelmeit és attitüdjeit a természettel kapcsolatban. Elemzéseik során - Mayer és Frantz-hoz hasonlóan — szintén egy domináns faktort találtak, de fő kérdésük ennek a faktornak a jelentése volt. A NEP és a CNS közötti különbséget Perrin és Benassi (2009) több okkal magyarázza:

- míg a CNS Skálánál a személyekre önmagukra utaló megfogalmazások vannak, addig a NEP általános, emberiségre vonatkozó megfogalmazást alkalmaz.

- a NEP megfogalmazásai negatívabbak, mint a CNS skáláé.

- a kutatás során Mayer és Frantz a CNS skálával egy kérdéscsoportban kérdezte le az Environmentalism skálát, míg a NEP Skála eltérő csoportban volt. Ez a megjelenítésbeli különbség is okozhat eltéréseket.

A szerzők nem vetik el a CNS használatát, csak hangsúlyozzák, hogy a skála nem érzelmeket, hanem kognitív hiedelmeket mér, esetleg az egyén és a környezet kapcsolatának kognitív személyiségbeli dimenzióját (Perrin és Benassi, 2009).

Azok a skálát használó kutatások, amelyek nem kérdőjelezik meg a skála által mért érzelmi kapcsolatot, a skála és a környezetbarát viselkedés korrelációját és a skála 
megbízhatóságát mutatták. A kutatások hangsúlyozzák, hogy az érzelmi kapcsolat a természettel egy kiterjesztett én-érzéshez vezet, amely a többi faj és a természet értékeléséhez és a környezetbarát magatartásokhoz vezet (Frantz és tsai., 2005; Gosling és Williams, 2010; Olivos és tsai., 2011).

\subsubsection{A TERMÉSZETHEZ VALÓ VISZONYULÁS SKÁLA}

A skálát Nisbet és munkatársai fejlesztették ki (2009). A Természethez való viszonyulás skála (Nature Relatedness, NR) koncepciója magába foglalja a világon lévő összes élölénnyel összefüggő kapcsolat megértését és megbecsülését (Nisbet és tsai., 2009).

A szerzők célja egy olyan komplex mérési eszköz kialakítása volt, amely a természethez való kötődés érzelmi, kognitív és tapasztalati aspektusát is figyelembe veszi. A természetben töltött élményszerü tapasztalat kulcseleme a környezeti érzékenységnek (Chawla, 1998, 1999, 2006), és a szerzők szerint ez az a szempont, amely minden korábbi egyén - természet kapcsolatot vizsgáló skálából hiányzik.

Az NR 21 állításból áll, amelyeket 5 fokú Likert skálán mérnek. Az elemzések alapján a skála 3 dimenziót fed le:

- NR - Szelf: ez a faktor a természettel való identifikáció mértékét mutatja, a természettel kapcsolatos vélemények és érzések megjelenése.

- NR - Perspektíva: a külső, természetorientált világkép megjelenése, az egyéni cselekvések hatásai miatti aggodalom.

- NR - Tapasztalat: az egyén tapasztalati ismerete a természeti világról, mennyire érzi komfortosan magát a természetben, illetve mennyire vágyik a természetbeli időtöltésre.

A skála erösen korrelál a környezeti attitüd mérésekkel. Nisbet és munkatársai ezt azzal indokolják, hogy az NR és a NEP koncepciója között erős hasonlóság van (Nisbet és tsai., 2009). A környezeti attitüd mérések és az NR között olyan mértékü korreláció áll fent, amely valószínűsíti, hogy a skála az attitüd mérésére alkalmas. A környezetbarát viselkedésekre gyakorolt hatása alapján azonban a szerzők azt a megállapítást teszik, hogy az NR koncepciója több, mint környezeti attitüd.

Az NR skála alkalmazását azért vetem el, mert a NEP-vel való erős kapcsolata azt jelzi, hogy nem csak a környezeti identitás, a környezet és az egyén közötti kapcsolatot méri, hanem egybemossa a környezeti attitüd koncepciójával. 


\subsection{IDENTITÁS, MINT A FOGYASZTÓI VISELKEDÉS ALAKÍTÓ TÉNYEZŐJE}

A személyiség elméletekről szóló fejezetben már hangsúlyt kapott az identitás azon funkciója, hogy hatással van az attitüdre, valamint az attitüd moderáló hatásán keresztül viselkedésirányító ereje is van. Ennek értelmében a környezeti identitás, ha kialakul az egyénben, befolyásolhatja a végzett környezetbarát tevékenységek mennyiségét és minőségét. Mindez akkor valósulhat meg, ha a környezeti identitás az adott döntés vagy választás meghozatalakor aktiválódott az egyén tudatában. Ez úgy jelenik meg, hogy az egyénben a számos eltérő társadalmi szerepéhez, társas csoportjához kötődő identitások közül aktuálisan a környezeti identitás lesz a legerősebben jelen, és döntése során figyelembe veszi, hogy az adott választás a környezethez közel álló, környezetet támogató énje számára is elfogadható legyen. A továbbiakban az identitás elérhetővé tételének lehetőségeit mutatom be.

Az emberek természetes módon vonzódnak azokhoz a termékekhez, amelyek az énképükhöz, illetve az identitásukhoz illeszkednek (Kleine és tsai., 1993; Reed és Forehand, 2003; Stayman és Deshpande, 1989). A fogyasztók azért választanak bizonyos termékeket, mert azok az eltérő társas identitásaikat szimbolizálják önmaguk és mások irányába is (Chattaraman és tsai., 2010). A szimbolikus előny a társas identitás attitüd funkciójaként definiálható. Ezáltal a fogyasztónak lehetősége van következetes viselkedésével kifejezni értékeit és attitüdjeit, valamint lehetősége van az adott helyzetekbe és csoportokba illeszkedni (Chattaraman és tsai., 2010). A szociális identitásnak erős hatása van a meggyőződés - attitüd - viselkedési szándék hármas kapcsolatára. Ebben a viszonyrendszerben az attitűd mediátor változóként jelenik meg (Madrigal, 2001).

A szociális identitás szerepének vizsgálata a fogyasztói magatartás irányításában és a marketing stimulusokra adott reakciók kialakításában egyre jelentősebb teret hódít (Chattaraman és tsai., 2010). Ezek a kutatások Tajfel (1981) Szociális Identitás Elméletének már bemutatott koncepcióin alapulnak. Jelen kutatás esetében a környezeti identitásra is mint szociális identitásra tekintek, a korábban bemutatott koncepciók alapján. Reed (2002) az identitás marketing területén való alkalmazásának fontosságát hangsúlyozza, arra építve, hogy a kiemelkedő szociális identitás pozitív értékeléshez vezet azon termék esetében, amelyik kongruens a releváns társas identitással. Ez a kapcsolat vagy azon alapul, hogy a termék a fogyasztó személyiségét szimbolizálja, vagy 
azon, hogy azt a személyiséget jelképezi, amilyenné a fogyasztó válni akar (Reed és Forehand, 2003).

A szociális identitás hatását vizsgálták és igazolták már számos fogyasztói magatartás kérdéskörben. A környezettudatos magatartás esetében Bartels és munkatársai (2011) kutatása megállapította, amennyiben a fogyasztó azonosul a környezettudatos fogyasztói identitással, annak indirekt hatása van az organikus termékek fogyasztására. Ezzel szemben, ha a fogyasztó az organikus terméket vásároló fogyasztói identitással azonosul, annak egyaránt erős direkt és indirekt hatása van az organikus termékek fogyasztására (Bartels és Hoogendam, 2011).

A szociális identitásnak akkor van jelentős hatása a fogyasztói attitüdre, a döntésekre és viselkedésekre, ha az identitás információi elérhetőek, vagy aktiváltak a fogyasztó fejében. Ezt a fogalmat nevezik a társas identitás észlelhetőségének (Reed, 2002). Minél erősebb az identitás elérhetősége, annál nagyobb a valószínüsége az identitáshoz illeszkedő viselkedés kialakulásának (Stryker és Burke, 2000). Az identitás hozzáférhetőség hatása azért alakul ki, mert a fogyasztók pozitív énképet szeretnének kialakítani magukról, ezért az identitással konzisztens információk értékelése pozitívabb (Wheeler és tsai., 2005). Ha egy identitás elérhetővé válik, azaz az egyén tudatában felszínre kerül, akkor az egyén többi identitása újrarendeződik, és az aktivált identitás válik észlelhetővé, és teszi a viselkedést konzisztenssé (Zhang és Khare, 2009).

A társas identitás akkor fejti ki ténylegesen a hatását, ha megfelel a következő szempontoknak. Egyrészről rendelkezésre kell állnia (availability), azaz a személy számára fontosnak kell lennie az aktuális öndefiniálásában, másrészről hozzáférhetőnek (accessibility) kell lennie, azaz a memóriából elő kell hívni, aktiválni kell az adott identitást (Reed és Forehand, 2003). Az aktív identitás arra ösztönzi az egyént, hogy az identitásnak megfelelően kategorizálja önmagát (Forehand és tsai., 2002; Forehand és Deshpandé, 2001).

A társas kontextus, a környezeti nyomok és a meglévő asszociációk a fogyasztó énfogalmáról és a társas identitásról kiválthatják az identitás észlelhetőségét és előfeszítik ${ }^{16}$

\footnotetext{
${ }^{16}$ priming, azaz előfeszítés, az egyik inger hatását jelenti a későbbi ingerre
} 
a későbbi az identitással kongruens attitüd és viselkedés kialakulását (Chattaraman és tsai., 2010). Részletesebben bemutatva:

1) Társas kontextus: az adott szociális identitás elérhetőségét növelheti a helyzet, ha valamilyen mértékben szokatlan, vagy megkülönböztethető. Általában a megkülönböztethetőségre vonatkozó kutatásokban az egyének azokat a fogyasztási helyzeteket emelték ki, amelyekben a fogyasztó a kisebbséghez tartozott (Reed és Forehand, 2003), például férfi fogyasztó a női ruhaüzletben.

2) Környezeti nyomok: ilyen lehetséges nyomnak tekinthető például a referenciacsoport egy szimbóluma, képek, vagy szavak. Az adott jelzések észlelése elősegíti az identitás aktiválását a memóriából. Mitchell és munkatársai (idézi Reed és Forehand, 2003) eredményei azt mutatták, hogy Michael Jordan értékelése pozitívabb volt, ha a sportoló identitást aktiválták, mint ha az afrikai amerikait. Ezek a környezeti nyomok elérhetővé teszik az identitást az adott szituációban.

Az „előfeszítés” vagy „,priming” kifejezés azt a hatást jelöli, amikor egy inger befolyásolja a feldolgozó rendszer további teljesítményét (Baddeley, 2003). Azaz az adott kiinduló inger miatt a később megjelenő ingerekre más választ, az előfeszítő ingerhez illeszkedő választ adunk. Ez a jelenség az implicit emlékezet létezését igazolja (Kónya, 1990). A pszichológiai kutatásokban az előfeszítő hatást az emberi emlékezet vizsgálatában alkalmazzák (például szótanulás).

A priming kutatások „,második generációja” az előfeszítési hatás igazolása után már olyan kérdéseket vet fel, mint hogy hogyan lehet az előfeszítés hatásait kontrolálni, vagy hogyan eredményezhet az előfeszítés eltérő hatásokat, illetve meghatározható-e, melyik identitás „győz” a versengő identitások közül (Bargh, 2006). A kérdés azért merült fel, mert ugyanaz az előfeszítő inger eltérő reakciókat váltott ki a fogyasztókból (kulturális identitás vizsgálata során). Az egyének demográfiai és pszichográfiai jellemzői egyaránt eltérő fogyasztói döntést eredményeznek. Az eredmények azt mutatják, hogy az egyéni különbségek moderáló változók lehetnek az előfeszítésen alapuló fogyasztói vásárlásokra (Wheeler és Berger, 2007), valamint a döntés függ a társas identitással való azonosulás erősségétől (Bolton és Reed, 2004; Reed, 2004). 
3) Az asszociáció erőssége az én és a szociális identitás között: mint ahogy már bemutatásra került, egy egyénnek egyszerre több identitása is lehet, és ezek között az identitások között hierarchikus kapcsolat van. Minél fontosabb az egyénnek a teljes én értelmezésében az adott identitás, annál valószínübb, hogy erős hatással lesz az adott döntési, illetve fogyasztási szituációban az identitás. Ezt a hierarchiát általában az azonosulás erőssége fogalommal illetik. Az identitás fontosságát erősíti, ha több lehetőség van az identitásnak megfelelően viselkedni, illetve visszajelzéseket fogadni az identitással kapcsolatban a társas kapcsolatokon keresztül (Kleine és tsai., 1993).

Más csoportosítás szerint az identitást két módon lehet elérhetővé tenni, egyrészről a tartós azonosulással (például tartós csoporttagság esetén azonosulunk az adott csoporttal), másrészről a szituációs előfeszítés segítségével (Zhang és Khare, 2009).

Annak érdekében, hogy a szociális identitás hatással legyen a viselkedésre, nem elégséges feltétel az identitás elérhetősége. Elengedhetetlen az identitás diagnosztikai erőssége is, hogy az identitás meghatározó legyen az adott döntés esetében. Ez két szemponttól függ (Reed és Forehand, 2003):

1) mennyire releváns a társas identitás az értékelés területére vonatkozóan, illetve

2) milyen mértékben segíti a fogyasztót a termékek közötti illetve a döntési alternatívák közötti különbségtételben az adott szociális identitás.

Amikor a fogyasztók hasonlóságot és kongruenciát észlelnek a cselekvés vagy márka és a szociális identitás között, akkor az identitáshoz kötődő értékelő tartalom hozzákapcsolódik az adott cselekvéshez vagy márkához is. Ezt a tárgy - identitás hasonlóságot 3 faktor okozhatja:

1) Szimbolikus relevancia: akkor beszélhetünk róla, ha egy meggyőződés kifejezése, vagy egy tárgy tulajdonlása a személy szociális identitását közvetíti, vagy a szociális identitás egy fontos elemét támogatja (Nelson és tsai., 1997 idézi: Reed és Forehand, 2003). Ez a szimbolikus fogyasztás alapja is (Solomon, 1983).

2) Cél-relevancia: ha egy meggyőződés, vagy cselekvés kötődik az elérhető szociális identitás szempontjából jelentős problémához, vagy kimenethez. Ezek a meggyőződések, vagy cselekvések magukba foglalhatják az attitüd kifejeződését, vagy a specifikus csoporthoz kötődő viselkedés kialakulását. A cél relevanciát 
gyakran a társadalmi normákhoz viszonyítva értékelik, amely magába foglalja a vágyott célokat is. A szociális identitás cél alapú tartalma az adott identitást birtokló egyénnek bizonyítékot nyújt a társas valóságról, és értékelő választ ad az identitás-releváns stimulusról is. Ez alapján a társas identitáshoz igazodó kommunikáció tervezése során figyelembe kell venni a normák implicit és explicit kommunikációját is.

3) Cselekvés-relevancia: annak a mértéke, mennyire teszi lehetővé egy tárgy az adott szociális identitáshoz kötődő cselekvés megvalósítását. Például minden identitáshoz kapcsolódó tulajdon egy koherens halmazt alkot az identitás körül. Ezek a tárgyak azok, amelyeket az egyén az identitásnak megfelelő viselkedés során hasznosnak tart. De a tulajdonlás nem elégséges, ami fontos, hogy az egyén milyen reakciókat vált ki más fogyasztókból az adott tulajdon használatakor. Minél inkább kötődik a tulajdon a szociális identitáshoz, annál inkább képesnek érzi magát a fogyasztó a szociális identitásnak megfelelő viselkedés véghezvitelére (Kleine és tsai., 1993; Laverie és tsai., 2002).

4) Megkülönböztetési képesség: a szociális identitásnak alkalmasnak kell lennie arra, hogy a fogyasztó az eltérő lehetőségek között különbséget tudjon tenni. Ha az identitás nem ad támpontot a választásban, az érthető és tiszta identitáshoz kötődő norma ad megfelelő bázist a döntés meghozatalához.

Az identitás használatát a viselkedésváltozás elérése érdekében a fejezetben bemutatott szempontok figyelembevételével lehet megvalósítani. A környezeti identitás esetében tehát az adott döntési szituációkban észlelhetővé kell tenni az egyének számára az identitást. Adott vásárlási szituációban, vagy egyéb fogyasztási döntés esetében az egyénnek tudatában kell lennie, hogy ő a természet része, a természethez közelállónak érzi magát és ennek érdekében hozza meg döntéseit. 


\section{A KÖRNYEZETTUDATOS FOGYASZTÁS TERÜLETÉN}

\section{ALKALMAZOTT FOGYASZTÓI MAGATARTÁS MODELLEK}

A korábbi fejezetekben áttekintettük a környezetbarát viselkedésre ható belső, személyes tényezők sorát. A viselkedés változás támogatása érdekében meg kell értenünk, hogyan kapcsolódnak össze a viselkedésre hatással lévő főbb tényezők, és hogyan hatnak a viselkedési szándék, illetve a valós viselkedés kialakulására. Ennek a megértéséhez modellek sora került kialakításra, amelyek a kiinduló alapfeltevéseik alapján csoportosíthatóak.

A modellek alapvetően eltérnek a komplexitásukat tekintve. A modellek egy része egykét kulcs tényezőt emel ki, amelyre fókuszál (lásd: Schwartz Norma Aktivációs Modellje (1977), Ajzen - Fishbein TRA modellje (1980)), amely elősegíti a modell könnyebb alkalmazhatóságát. Másik része a folyamat komplexitását kívánja megragadni, és az összes lehetséges tényezőt beépíti a modellbe (lásd: Gatersleben - Vlek NOA modellje (2002), Ölander - Thøgersen MOA modellje (1995), Stern ABC modellje (2000)). Ezek a modellek a konceptuális megértést segítik elő, de nehezen validálhatóak.

Fontos kiemelni, hogyan vélekedik a fogyasztóról az adott modell, mennyire tekinti racionális, vagy korlátozottan racionális fogyasztónak. A racionális döntési modellek alapja, hogy a fogyasztó célja saját hasznossági függvényének maximalizálása. Ezekben a döntési modellekben az egyén van a középpontban, valamint az általa meggondolt, racionális érvek mentén meghozott értékelés és választás (Jackson, 2005b). A racionális modelleket alkalmazták az egészségügy és a fenntartható fogyasztás területén is (Ryan és Bate, 2001).

A racionális modellek alapfeltevése, hogy az egyén önérdekkövető. A környezettudatos viselkedés területén végzett kutatások azonban azt mutatják, hogy a környezettudatosság kialakulásának egyik erős motivációja az altruista, illetve bioszférikus motiváció (Schultz, 2000). Disszertációm központba helyezett fogalma, a környezeti identitás is abból a feltevésből indul ki, hogy az egyén a természettel közösséget, egységet érezve válik hajlandóvá és képessé környezetbarát viselkedés megvalósítására. A proszociális motívumokat hangsúlyozó modellek az értékeknek és a normáknak, a személyes tényezőknek nagyobb szerepet tulajdonítanak (lásd: Schwartz Norma Aktivációs 
Modellje (1977), Stern VBN Modellje (2000)). Azok a kutatók, akik az egyéni önérdekkövetést tartják a környezetbarát viselkedés fö motivációjának a racionális döntési modellek közül a Tervezett magatartás modelljét (Ajzen, 1991) alkalmazzák leggyakrabban, azok a kutatók pedig, akik a proszociális motívumokat hangsúlyozzák (Bamberg és Möser, 2007) a Norma Aktivációs Modellt (Schwartz, 1977).

A modellek között különbséget tehetünk aszerint, hogy inkább a külső, szituációs tényezőkre helyezik a hangsúlyt, mint a pénzügyi lehetőségek, szervezeti körülmények, szabályozási közeg, vagy a belső, személyes jellemzőkre, mint az attitűd, értékek vagy a személyes norma (Jackson, 2005b). A marketingkutatás területén mind a két irányvonalnak meg kell jelennie. Az internalista szemléletmód feltételezi, hogy a viselkedésváltozás az értékek, meggyőződések, attitüdök változásán alapul, amelyet a társadalmi marketing (Andreasen, 2006; Kotler és Zaltman, 1971) eszköztárának a segítségével lehet elérni. Az externalista szemléletmód a fogyasztó útfüggőségét ${ }^{17}$ hangsúlyozza, a külső gazdasági kényszerüség, a piaci környezet, és a társadalmi elvárások hatását. Ekkor a stakeholderek (vö.: 2.2 fejezet) fogyasztási környezetet alakító tevékenysége segíti elő a környezetbarát viselkedés kialakulását, amelyhez az ökomarketing (Csutora és Kerekes, 2004; Henion és Kinnear, 1976), mint a választások átalakítását segítő eszköz áll rendelkezésre.

Disszertációm során az internalista szemléletmódot alkalmazom, kutatásom fókuszában az egyének személyes tényezői állnak. A modellek közül azokat emelem ki, amelyek a fent bemutatott jellemzők alapján a leginkább alkalmazhatóak kutatásom során. (A további modellek részletes bemutatását lásd: (Jackson, 2005b))

1) Ajzen és Fishbein (1980): Indokolt cselekvés elmélete (TRA: Theory of Reasoned Action)

Az indokolt cselekvés elméletében (TRA: theory of reasoned action) Ajzen és Fishbein (Ajzen és Fishbein, 1980) egy egyszerüen használható modellt alkotott. A modell kiemeli, hogy az attitüdök nincsenek közvetlen hatással a magatartásra, ellenben a cselekvési szándékot befolyásolják. A cselekvési szándékot 3 tényező alakítja, az attitüdök és a szubjektív norma, továbbá a szubjektív normának tulajdonított relatív fontosság (Jackson, 2005b). A normák erős hatását több

\footnotetext{
${ }^{17}$ lock-in
} 
kutatás is igazolta (Bagozzi és Schnedlitz, 1985), alkalmazható a környezetbarát magatartás vizsgálatára is.

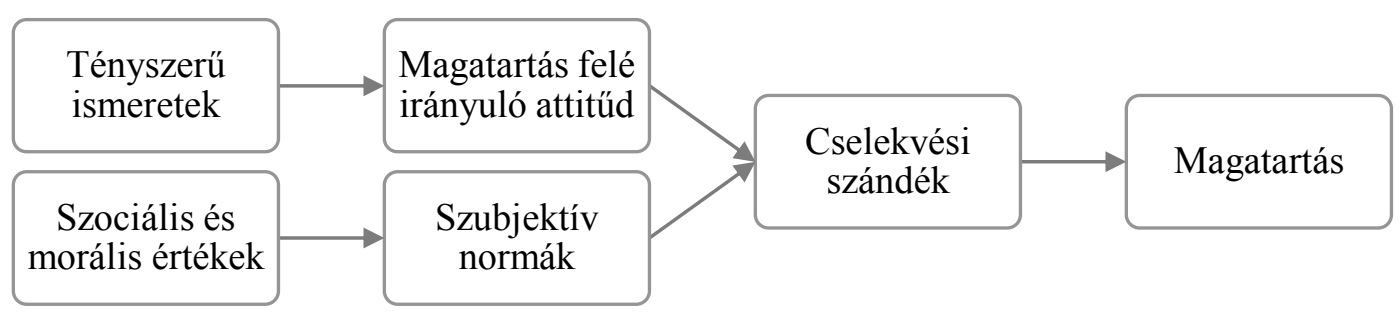

\section{4. ábra: Indokolt cselekvés elmélete}

Forrás: Ajzen és Fishbein, 1980 alapján

\section{2) Ajzen (1985 és 1991): Tervezett magatartás modellje (TPB: Theory of Planned Behavior)}

A TRA modell továbbfejlesztett változata a tervezett viselkedés elmélete (TPB: theory of planned behavior). A modellben az irányitó hiedelmek és következményükként az észlelt magatartás-irányitás új elemként jelennek meg (Ajzen, 1985, 1991).

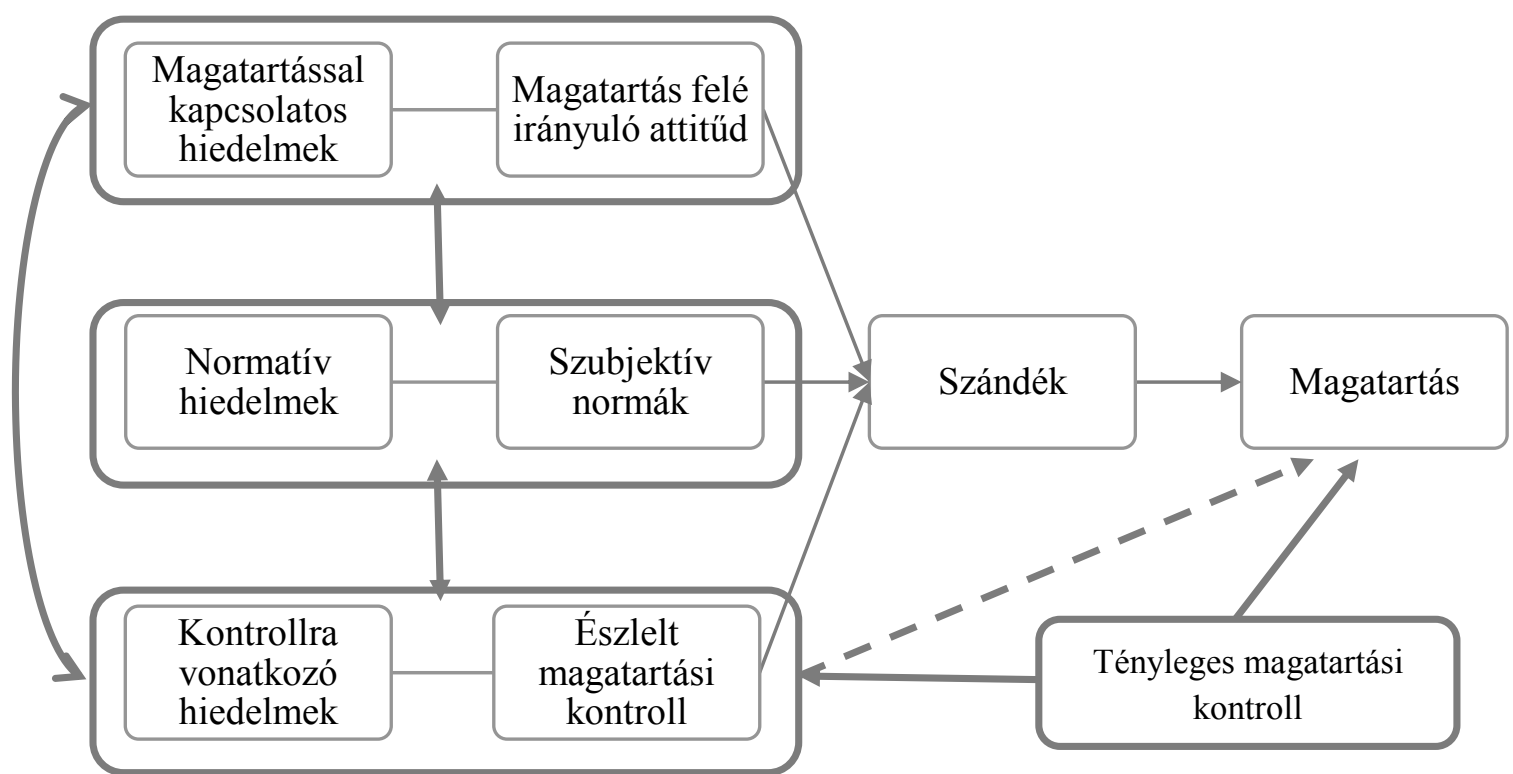

5. ábra: A tervezett viselkedés elmélete

Forrás: Ajzen, 1991 alapján 
Ajzen modelljében jelentős hangsúlyt helyez az észlelt magatartásirányításra, amely nemcsak a cselekvési szándékon keresztül, de közvetlenül is befolyásolja a magatartást. A modell az aktuális magatartásirányitás elemével bővülve válik dinamikussá (Ajzen, 2002). Az aktuális magatartásirányítás arra utal, mennyire képes az egyén adott helyzetben magatartásával a kívánt hatást elérni.

A TPB modellt nagyon gyakran alkalmazzák a környezettudatosság vizsgálatára, már egy 2001-es meta-analízis során 154 eltérő kontextusbeli alkalmazását figyelték meg (Armitage és Conner, 2001).

\section{3) Hines, Hungerford és Tomera (1986): Felelős környezeti magatartás modellje}

A modell a TRA és a TPB koncepcióhoz képest bővült a személyiség szempontjainak kiemelésével, magába foglalja az attitüdöt és a viselkedés kontrollt is. Hangsúlyozza a problémák ismeretén túl a cselekvési stratégiák ismeretének a cselekvési szándékot befolyásoló szerepét is (idézi Zsóka, 2007). Emellett újdonságként megjelennek a szituációs tényezők (gazdasági helyzet, társadalmi nyomás, infrastruktúra hiánya, stb.) is, amelyek ebben a modellben közvetlenül a valós magatartásra hatnak (Hines és tsai., 1986).

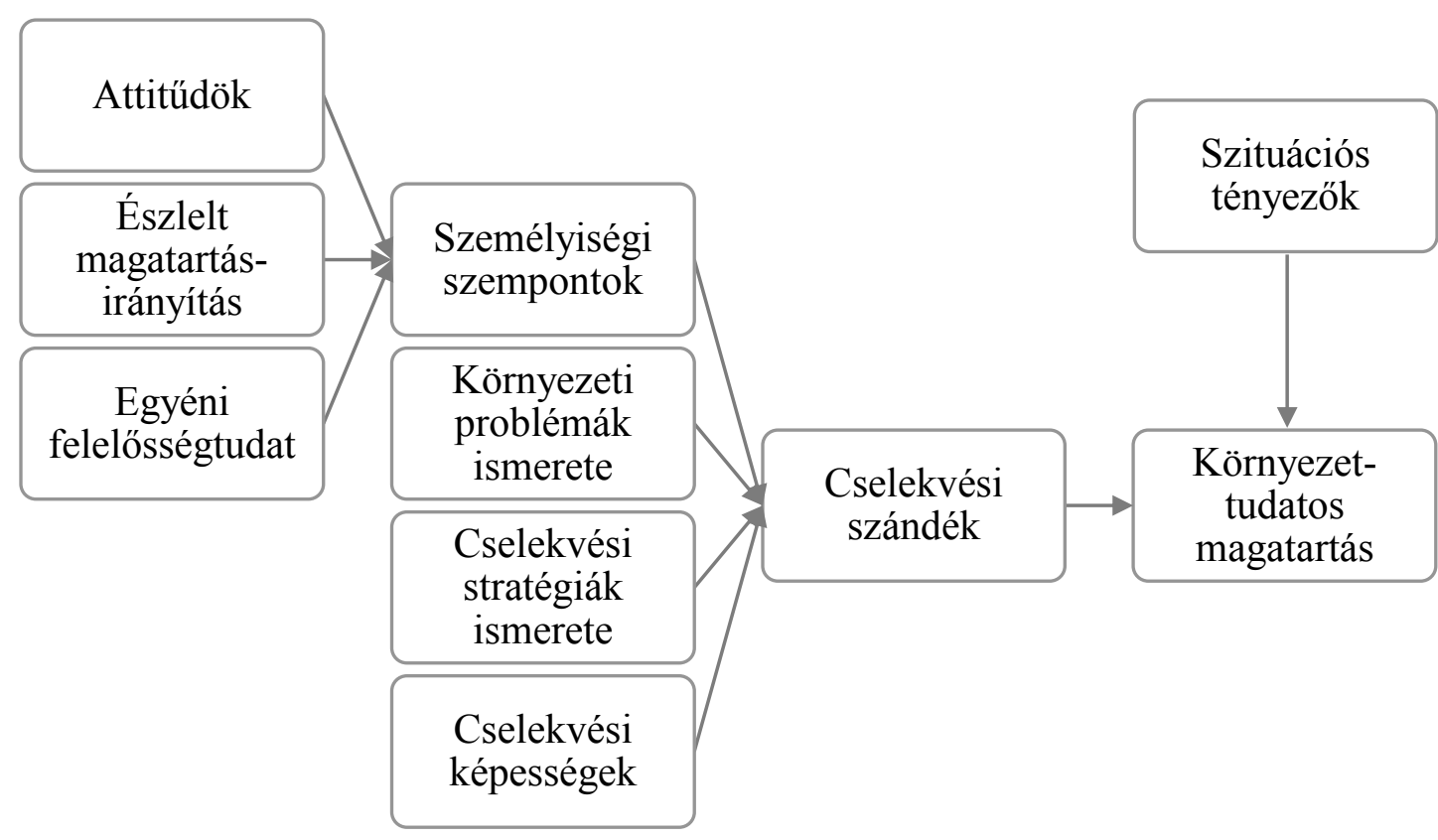

\section{6. ábra: Felelős környezeti magatartás modellje}

Forrás: Hines és mtsai, 1986, idézi Zsóka, 2007, 48 o. alapján 
Míg a többi modell általános, több magatartás típus vizsgálatára is adaptálható, e modell erőssége, hogy kifejezetten a környezettudatos magatartás vizsgálatára alkalmas.

\section{4) Schwartz (1977): Norma Aktivációs modell}

A TPB mellett ezt a modellt alkalmazzák leggyakrabban a környezettudatosság vizsgálata területén. Eredeti célja a pro-szociális, altruista viselkedés keretének a megértése volt (Schwartz, 1977). A modell alapja, hogy a személyes norma, mint erős morális kényszerérzés, a pro-szociális viselkedés iránti elköteleződés egyetlen közvetlen meghatározó tényezője. A személyes normának két előzménye van, a cselekvések következményének ismerete és a következményekért vállalt személyes felelősség elfogadása. A modell neve arra utal, hogy a következmények ismerete és a felelősségvállalás aktiválja a személyes normát, amely meghatározza, hogy az egyénnek a környezetkárosító következmény elkerülése érdekében közbe kell-e lépnie (idézi: Cordano és tsai., 2011). A modellt a beavatkozó viselkedés elméletének is hívják, mert akkor lép életbe, ha az egyén azt észleli, hogy a folyamatok káros következményekkel járnak a környezete és önmaga számára. Eredetileg Schwartz az altruizmus modelljének hívta.

A modell magyarázó ereje változó, a legerősebb faktor, ami a személyes norma hatására közrehat, az a külső társadalmi és intézményi keret (Jackson, 2005b).

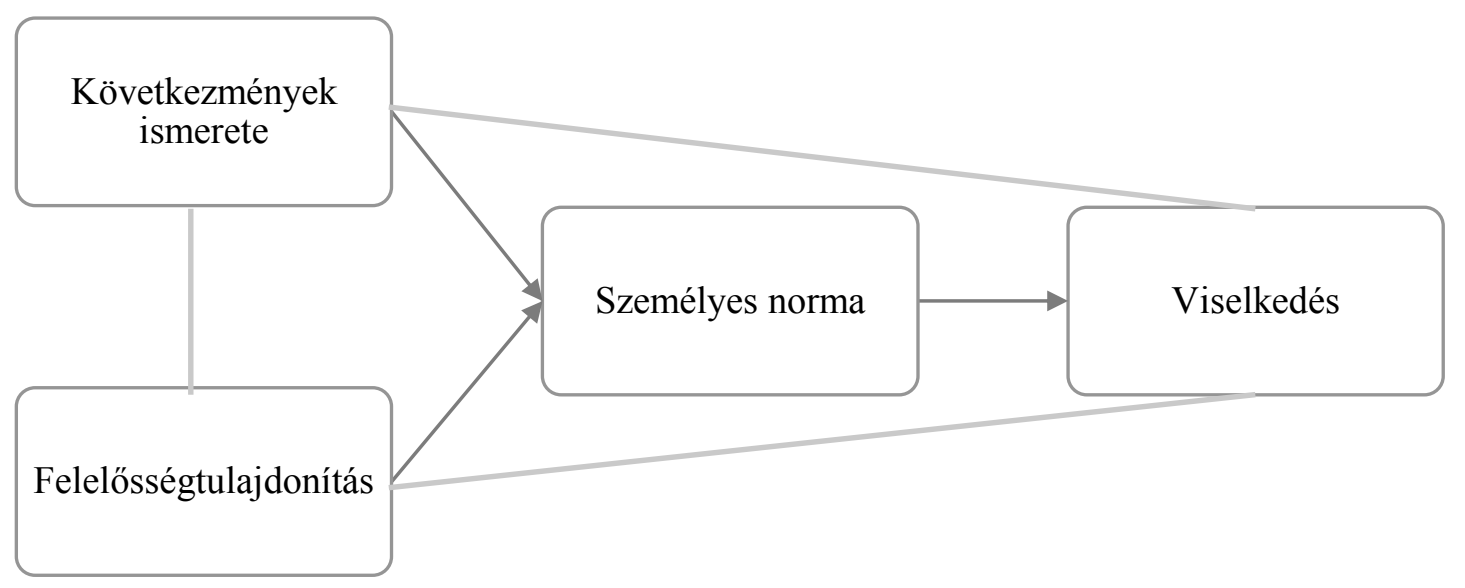

\section{7. ábra: Norma Aktivációs Modell}

Forrás: Schwartz, 1977 alapján 


\section{5) Stern (1999): Érték - Hiedelem - Norma Modell}

Stern elmélete is a norma aktiválás koncepcióján alapul. A Schwartz-féle modellhez képest a különbséget az értékek és a világnézet tényezőinek integrálása jelenti, a pro-szociális viselkedés kialakulását Schwartzhoz hasonlóan a segítség normájának aktiválásával magyarázza (idézi Cordano és tsai., 2011).

Az elmélet feltételezi, hogy az Új Környezeti Paradigma, azaz a NEP (mint attitűd), meghatározó előzménye a következmények ismeretének. A NEP elfogadása pedig a bioszférikus és az altruista értékorientáció megjelenésétől függ. A modell vizsgálja az egoista értékek hatását is, amelyek a kutatások alapján negatívan korrelálnak a pro-szociális viselkedéssel.

A NEP elfogadása pozitívan korrelál a következmények ismeretének kialakulásával és a felelősségtulajdonítással. Ezek alapján aktiválódik a személyes norma (Stern és tsai., 1999).

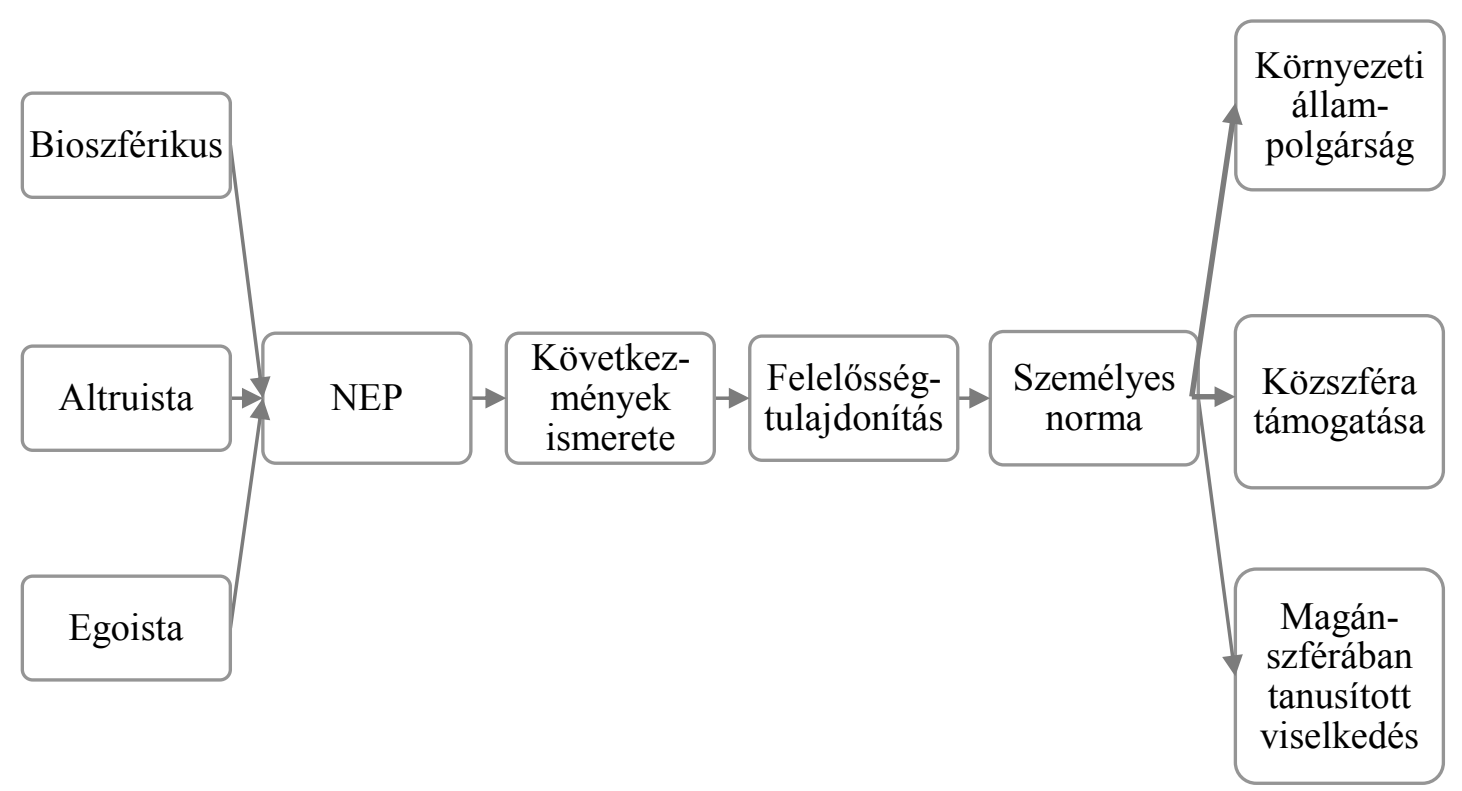

8. ábra: Érték - Hiedelem - Norma Modell

Forrás: Stern, 1999 alapján

Stern (2000) szerint - a többi modellel összehasonlítva - a modell biztosabb előrejelzője a környezeti állampolgárságnak, a magánszférában tanúsított viselkedésnek és a közszféra támogatásának is.

A bemutatott modellek mind az egyéni, személyes, pszichográfiai tényezők jelentőségét hangsúlyozzák, és a közöttük lévő kapcsolatokat vizsgálják. A bemutatott modellekben 
az identitás változó az elmúlt években jelent meg; az identitás szerepének a vizsgálata során elindultak a fogalom modellbe rendezésére tett kísérletek (Davis és tsai., 2009; Hinds és Sparks, 2008).

Az egyik leggyakrabban alkalmazott koncepcionális modell, amelybe az identitás koncepcióját megpróbálták beépíteni, a TPB modell. Az én-identitás változó modellbe építésével erősödik a modell magyarázó ereje (Fielding és tsai., 2008). Egyre növekszik azon kutatások száma, amelyek igazolják, hogy az én-identitás jelentős tényező a cselekvési szándék előrejelzésére (Fielding és tsai., 2008; Hogg és tsai., 1995; Sparks és Guthrie, 1998; Sparks és Shepherd, 1992; Terry és tsai., 1999; Theodorakis, 1994). Sparks és Shepherd (1992) úgy érveltek, hogy az én-identitás az attitüdökön keresztül hat, ugyanakkor kutatásuk eredményei szerint a zöld-fogyasztói én-identitás független előrejelzőnek bizonyult az organikus termékek vásárlási szándékának előrejelzésére. Az identitás ezek alapján hasznos tényezője lehet a viselkedést magyarázó modelleknek, méghozzá az attitűd jellegü értékeléseket megelőző tényezőként (Thorbjørnsen és tsai., 2007).

Disszertációm további fejezeteiben a bemutatott szakirodalmi eredményekre alapozva a környezeti identitás és a környezetbarát viselkedés kapcsolatának vizsgálatára végzett empirikus kutatás lépései kerülnek bemutatásra. 


\section{ELÖTANULMÁNYOK}

A környezettudatos viselkedés és fogyasztás vizsgálatával 2008 óta foglalkozom. 2008tól a Norvég Alap Fenntartható fogyasztás, termelés és kommunikáció kutatócsoport tagjaként az európai és a hazai környezetbarát fogyasztói magatartásminták változásának vizsgálatával foglalkoztunk Kasza-Kelemen Kata kollégámmal, Hofmeister-Tóth Ágnes projektvezetésével. 2010-től a Norvég Alappal elkezdett munkánkat a TÁMOP támogatásával létrejött Fenntartható fejlődés kutatócsoport fogyasztást vizsgáló alprojektjében folytathattuk tovább. Ezek a kutatási projektek lehetőséget nyújtottak a környezettudatos viselkedés vizsgálatában való elmélyülésre, és kiindulópontot biztosítottak disszertációm kutatásának megtervezéséhez.

Disszertációm célja a környezeti identitás és a környezettudatos magatartás kapcsolatának vizsgálata. A környezeti identitás környezettudatos viselkedésre gyakorolt pozitív hatását feltételezem, mind közvetlenül, mind közvetetten további pszichográfiai tényezőkön (lásd 3. fejezet) keresztül. Annak érdekében, hogy a környezeti identitás szerepét vizsgálni és igazolni tudjam előtanulmányaim során a környezeti identitás koncepció operacionalizálását támasztottam alá. Két elötanulmányt készítettem, melyeknek célja a természet értelmezésének és a természethez kötődő érzelmeknek és attitűdöknek a feltárása volt, illetve a környezeti identitás koncepcióra megalkotott skálák alkalmazhatóságának a tesztelése.

\subsection{KValitatív Kutatás A Természethez VAlÓ KÖTÖDÉS VIZSGÁLATÁRA ${ }^{18}$}

A természet és az egyén kapcsolatára a társadalom és az egyéni tapasztalatok erős hatással vannak. A környezeti identitás mérések alkalmazása előtt egy eltérő kulturális környezetben vizsgálni kell, mit értenek pontosan az egyének a természet fogalmán (Piskóti, 2013).

A kutatás célja a természethez való kötődés, a környezeti identitás megjelenésének kvalitatív vizsgálata volt, annak érdekében, hogy feltérképezze megjelennek-e a magyar

\footnotetext{
${ }^{18}$ A tanulmány megjelent a MOK Konferencián 2012-ben (Piskóti, 2012)
} 
környezetben a nemzetközi skáláknál használt tényezők. A kutatás jellege feltáró, célja az egyetemi hallgatók természetről alkotott képének értelmezése volt, annak a megismerése, hogy mely élmények, gondolatok, érzelmek jutnak elsőre eszébe a válaszadóknak a természet szó kapcsán.

\subsubsection{A KUTATÁS MÓDSZERTANA}

A környezeti identitás dimenzióinak vizsgálatára kiindulásként kvalitatív kutatást végeztem. A kutatás 2011. második negyedévében zajlott a Budapesti Corvinus Egyetem akkor elsőéves mesterszakos hallgatóinak körében. A kutatásban való részvétel önkéntes jelleggel történt, a válaszadást a kötelező teljesítményen felül szerezhető pontokkal motiváltuk. 34 hallgatói esszé pár készült el, amelyekben a kutatás résztvevői a természethez kötődő pozitív és negatív élményeiket mutatták be.

A kutatás narratív elemzés technikájával készült, amelyet a kutatás feltáró jellege indokolt. A narratív megközelítés segítségével a természetet, mint jelenséget az elbeszélés által lehet megismerni. A módszer célja, hogy a válaszolót minél kisebb befolyás mentén kérdezze meg az adott jelenségről. A narratív elemzés empirikus, szövegre alkalmazott kutatás, melynek célja annak megismerése, hogyan müködnek a történetek, mire és hogyan használják az emberek a történeteket (Szokolszky, 2004).

A válaszadók a kutatás során személyes történeteket írtak le. Arra a felszólításra, hogy „Emlékezz vissza életednek egy olyan eseményére, amely során nagyon boldog voltál, és valamilyen módon a természethez kapcsolódik! Írd le minél részletesebben, miért emlékezetes ez számodra!” pozitív érzelmi töltetű történeteket, illetve az „Emlékezz vissza életednek egy olyan eseményére, amikor rosszul érezted magad a természetben! Írd le minél részletesebben, miért emlékezetes ez számodra!" negatív érzelmi töltetű történeteket meséltek el.

Az esszék elemzése az Atlas Ti 5.2 kvalitatív elemző szoftver segítségével történt, nyílt elemzéssel, majd a környezeti identitás megfigyelése érdekében a dimenziók alapján zárt elemzéssel. Az elemzés fókuszában így a természet értelmezése, az élmények társas vagy egyéni jellege, valamint a környezeti identitás korábban meghatározott jellemzői állnak.

\subsubsection{A KUTATÁS EREDMÉNYEI}

A válaszadók között nemek szerinti megoszlást tekintve 6 férfi és 28 nő volt. Átlagéletkoruk 23,3 év (a legfiatalabb 22, a legidősebb 25 éves) volt. Állandó lakhely 
szerint 16 fö a fővárosban él, 8 fő egyéb megyeszékhelyen, 6 fö egyéb városban, 4 fő pedig „falu vagy egyéb községet” jelölt meg.

Minden válaszadó 2 esszét készített; az első a természetben átélt pozitív élményekről, a második a negatív élményekröl szólt. Az esszék terjedelme válaszadónként eltérö, a rövid (100 szavas) esszétől a terjedelmesebb (600 szavas) esszékig, átlagosan 250 szóval. Az eltérések azonban csak a válaszadók között figyelhetők meg, egy válaszadó hasonló terjedelemben írta meg a pozitív és a negatív élményeit is; az érzelmi irányultság nem volt hatással az esszék terjedelmére.

\section{A természet értelmezése}

A természet és az én kapcsolatának vizsgálata során kiemelt fontosságú, hogy megértsük, mit tekintenek a válaszadók természetnek, mit értenek természet alatt. Az egyének kötődése jelentősen függ ettől az értelmezéstől. Ennek érdekében az instrukciókban a természet szó minden további magyarázat nélkül jelent meg, meghagyva a szabad értelmezés lehetőségét.

Természet alatt a válaszadók több természeti jelenséget is megfogalmaztak (lásd 9. ábra). $\mathrm{Az}$ esszék több mint harmadában $(28 \mathrm{db})$ a természet, mint kirándulás jelent meg. A hegyvidéken, erdőben való túrázás adja a legintenzívebb élményt a természet kapcsán. Ezek az élmények pozitív (15 esszé) és negatív (13 esszé) tapasztalatként is megjelentek. A második legintenzívebben megjelenő értelmezés a természetet az időjárással kapcsolta össze. Ezt az értelmezést azért kell kiemelni, mert ez 87\%-ban a negatív élményekhez (2 pozitív és 14 negatív esszé) társult. A természethez kötődő negatív élmények majdnem fele nagy viharhoz, hirtelen esőhöz és hideghez kapcsolódott. (A bemutatáshoz kötődő idézeteket a Melléklet tartalmazza).

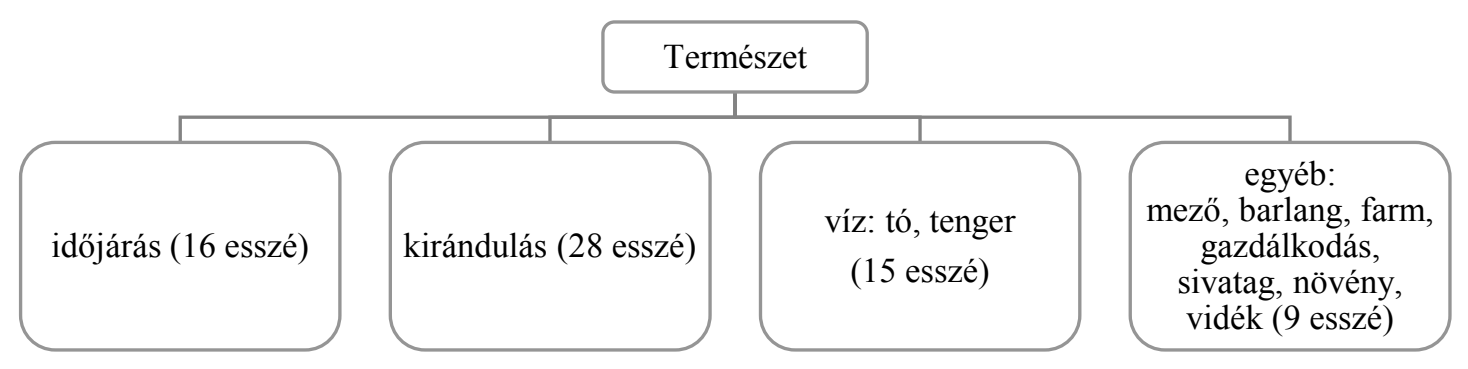

9. ábra: A természet értelmezése pozitív és negatív esszékben együttesen Forrás: saját szerkesztés 
Az értelmezés harmadik jelentős kategóriája a víz. Itt megjelent a folyókhoz, tavakhoz és tengerekhez kötődő emlék is. Általában pozitív élmények kötődtek a víz látványához, ami lelki megnyugvást és feltöltődést jelent a válaszadóknak. A válaszadók a vízről szóló történetek esetében szabadságérzésről, teljes kikapcsolódásról és nyugalomról számoltak be.

Az esszék témáiban egyedi jelleggel megjelentek még a növények, állatok, és egyéb lehetőségei a természetnek; ezek jelentősége azonban az alacsony számosságuk miatt elhanyagolható.

\section{A történetek időbelisége}

A történetek legnagyobb arányban gyermekkorból származtak (25 db esszé). Itt a megoszlás kiegyensúlyozott a pozitív (12 db) és a negatív (13 db) esszék között. 18 történet a középiskolai tapasztalatokon, élményeken alapult ( $8 \mathrm{db}$ pozitív és $10 \mathrm{db}$ negatív élmény), 9 az egyetemi évek alatt történt ( 6 db pozitív és 3 db negatív élmény), míg 14 esszé esetében az esemény megtörténésének idejére nem reflektált a válaszadó.

A gyermekkori tapasztalatok fontosságát a környezeti érzékenység és a környezettudatos viselkedés kialakulása szempontjából számos kutatás igazolta (Chawla, 1998, 2006). Az esszékben a gyermekkori történetek két típusú esemény köré csoportosultak. Az egyik típusba tartoznak a család szerepét hangsúlyozó rendszeres családi kirándulások, illetve családi telken, nagyszülői kertben szerzett élmények, a másik típusba az általános iskola által szervezett erdei iskolák, illetve osztálykirándulások élménye tartozik.

A negatív élmények esetében is megtalálható a családi, illetve az iskolai kirándulások jelentősége. Az iskolai kirándulások során szervezett éjszakai „bátorságtúrák” visszatérő félelmet keltő élményekként jelentek meg.

A középiskolai élmények többsége szintén az osztálykirándulásokra, közös túrázásokra vonatkozott, de már megjelentek az egyénileg szervezett baráti nyaralások is. Az egyetemi élmények esetében pedig csak a párral, barátokkal történő, egyénileg szervezett kirándulások jelentek meg.

\section{A történetek társas jellege}

A válaszadók az esszék 79\%-ában társas élményekről számoltak be. A természetjáráshoz, a természetben való időtöltéshez hozzátartozik a társaság is. Több esszében megjelent a társaság igénye, az élménymegosztás fontossága, mint a természethez kötődő pozitív élmények szerves része. 
Sem a társas, sem az egyéni élmények esetében nincs jelentős eltérés az élmény pozitív vagy negatív jellege között. Hasonló arányokban jelent meg minkét esszécsoportban a társas illetve önálló élmény (pozitív: 28 társas, 6 egyéni élmény; negatív: 26 társas, 8 egyéni élmény).

A természetben szerzett egyéni élmény elősegítheti a személyes nyugalom megtalálását. Ahogy a környezeti pszichológia hangsúlyozza (Kaplan, 1995; Kaplan, 2000) a természetnek pozitív hatása van az ember pszichéjére, megnyugtató és önbecsülés erôsítő hatása lehet. Mind a negatív, mind a pozitív élményeket bemutató esszékben megjelent a természet jótékony, önreflexiót elősegítő pszichológiai hatása.

\section{A környezeti identitás megjelenése}

A környezeti identitást, a szakirodalomban megalapozott (lásd: 5.3.1 fejezet) öt dimenzió mentén kódoltam: Ideológia, Azonosulás, Vonás kiemelkedősége, Pozitív érzelmek és Életrajzi elemek. A dimenziók közül a Pozitív érzelmek dimenziója került a leggyakrabban kódolásra, majd az Életrajzi elemek és a Vonás kiemelkedősége, míg az Azonosulás és az Ideológia összetevők alig jelentek meg az esszékben (5. táblázat).

\begin{tabular}{|c|c|c|c|}
\hline & Megjelenés száma & Pozitív élményben & Negatív élményben \\
\hline Azonosulás & 5 & 5 & 0 \\
\hline Életrajzi elemek & 23 & 18 & 5 \\
\hline Ideológia & 4 & 3 & 1 \\
\hline Pozitív érzelmek & 52 & 50 & 2 \\
\hline Vonás kiemelkedősége & 11 & 11 & 0 \\
\hline Összesen & 95 & 87 & 8 \\
\hline
\end{tabular}

5. táblázat: A környezeti identitás dimenzióinak kódolási gyakorisága

Forrás: saját szerkesztés

\section{Pozitív érzelem}

A pozitív érzelemhez kódolható gondolatok jellemzően a környezet esztétikai jellemzésére vonatkoztak, a természet szépségének és különlegességének kiemelésével. A korábban már kiemelt nyugalom mellett a természet a szabadság érzetét is adja az embereknek. A természetben töltött idő az önértékelést is segítheti. Ennek a része az esetleges kihívás is a természetben, amelyeket teljesítve az egyén sikerélményhez jut, és büszke lesz magára.

Természetesen a pozitív érzelmek a pozitív esszékben jelentek meg leggyakrabban, de a negatív élményekről szóló esszékben is megjelent a kompetencia érzése, mint pozitívum. DeYoung (2000, idézi: Clayton és Opotow, 2003) hangsúlyozza a kompetencia iránti vágy jelentőségét a környezetbarát viselkedés motiválásában. Ez tükröződik vissza jelen 
kutatásban is. A kompetencia az önállóság érzéséböl, önmagunk megvédésének képességéből fakad, abból, hogy saját erőből sikerül a természetben „túlélni”, akár megmászni a meredek hegyeket, vagy megbirkózni a sötétségtől való félelemmel (Clayton és Opotow, 2003). Egy nagy teljesítmény megtétele büszkeséggel tölti el az embert, azáltal is, hogy megismeri saját fizikai képességeit.

Emellett az életrajzi elemek azok, amelyek a negatív élményekben is relevánsan megjelentek.

\section{Életrajzi elemek}

A válaszadók gyakran fontosnak érezték, hogy gyermekkori életmódjukat, családi viselkedésmintáikat, jellemzőiket leírják az esszékben, mintegy igazolva elköteleződésüket.

Néhány válaszadó az életrajzi események leírásával a családi hatást, a jó minta tanulását és annak követését hangsúlyozta, kiemelve a családi példamutatás fontosságát a gyermekkorban.

A negatív élményről szóló esszékben az életrajzi elemek megjelenése a gyermekkori félelmekre utal vissza (pl. állatoktól), illetve a gyermekkor körülményeire, mint a helyszín, amelyet a szakirodalom szintén kiemelt hatású tényezőként kezel a környezetbarát magatartás kialakulásában.

\section{Vonás kiemelkedősége}

A természetben töltött idő gyakoriságának és jelentőségének hangsúlyozása nem volt jellemző az esszékre, 11 alkalommal került kódolásra, és kizárólag a pozitív élményekről szóló esszékben.

\section{Azonosulás}

A természettel való azonosulás, közösség érzése ritkán fogalmazódott meg az esszékben. Ez a hallgatói mintával is indokolható; nem kiemelten az elkötelezett személyek csoportjára fókuszált a minta ${ }^{19}$.

\footnotetext{
${ }^{19}$ A környezeti identitás skála 24 állitásból álló verziója lekérdezésre került a hallgatók között. Az eredmények alapján a résztvevők között nem volt kiemelten, a nemzetközi adatokhoz viszonyítva magas környezeti identitás score-ral rendelkező válaszadó.
} 


\section{Ideológia}

Az ideológia dimenzió úgy jelent meg az esszékben, mint a leendő gyermekeik iránti felelősség és a gyermekek természet szeretetére való nevelés kötelessége. Nem meglepő módon, mindegyik ilyen esszét nő készítette.

Emellett megjelent a negatív élményekben az a morális értékrend is, hogy a természetet óvni és nem rombolni kell, még akkor is, ha a természet a viharok által magát rombolja.

A környezeti identitás elemei összesen 95 alkalommal kerültek kódolásra; átlagban egy válaszadónál 2,8-szor jelent meg a környezeti identitás valamely tényezőjének kódja (Min=0, Max=7, Módusz=3). Az alacsony értékek visszavezethetők a minta jellemzőire, és az esszék rövid terjedelmére.

\subsubsection{AZ EREDMÉNYEK ÖSSZEFOGLALÁSA ÉS A KUTATÁS KORLÁTAI}

A kutatás célja a természet értelmezésének, valamint a környezeti identitás dimenzióinak vizsgálata volt. A természet alatt a válaszadók a természeti környezet számos konkrét vagy absztraktabb elemét értették (erdő, víz, időjárás), amelyek erősen összekapcsolódtak a természetben végezhető emberi tevékenységekkel is (például kirándulás, úszás). Összefoglalva látható, hogy a kutatás során a természetet érdemes minél tágabban értelmezve kezelni. Erre az 5.3-as fejezetben bemutatott mérési eszközök alkalmasak.

A kutatás eredménye a természethez kapcsolódó élményekben megjelenő társas jelleg értelmezése. A természet szeretetéhez a hallgatói esszékben szorosan kapcsolódott a társaság fontossága. Az élményeknek még intenzívebb érzelmi töltetet nyújt a jó társaság, baráti és családi közösségek megjelenése, az élmények közös megélése. Ennek a jelenségnek a környezeti identitásra való hatását további kutatással szükséges igazolni.

A dimenziókat vizsgálva (részletesen lásd 5.3.1. fejezet) a tartalomelemzés során eltérő arányban, de mind feltárhatóak voltak. A pozitív érzelem volt a legdominánsabban megjelenő dimenzió. Ezt részben az a felszólítás váltottak ki, amely a környezetben töltött legboldogabb és legnegatívabb élmény bemutatására kérte a válaszadókat. Várható volt, hogy az érzelmi élmények előfeszítése miatt az érzelem dimenzió erőteljesen kiemelkedik a hallgatói esszékben. A többi dimenzió alacsonyabb számossággal, de értékelhető módon jelent meg. 
$\mathrm{Az}$ eredmények emellett alátámasztják a gyermekkori élmények és természetbeli tapasztalatok fontosságát, amelyet a szakirodalom is hangsúlyoz (Chawla, 1999; Palmer, 1993; Tanner, 1980), azáltal, hogy a pozitív élmények 36\%-a gyermekkorból származik, további $24 \%$-a középiskolai élményeken alapul. A szerepminták fontossága is megjelenik az életrajzi események dimenzióban, a családi emlékek között leghangsúlyosabban a szülőktől, nagyszülőtől tanult tevékenységek emelkedtek ki.

A kutatás hallgatói mintán készült, azon belül is 34 válaszadó esszéin alapul. A minta kis számossága és a hallgatói minta speciális jellemzői korlátai a kutatásnak, és okozhatják a környezeti identitás dimenzióinak kiegyenlítetlen megjelenését. A kutatás korlátai miatt az eredmények kiindulási pontnak tekinthetőek; de javasolt a kutatás megismétlése egy nagyobb számosságú, környezettudatos viselkedés alapján elkötelezettnek tekinthető személyeket is tartalmazó mintán annak érdekében, hogy megfelelően feltárható legyen az elkötelezett és nem elkötelezett csoportok közötti különbség.

\subsection{KVANTITATÍV KUTATÁS A KÖRNYEZETI IDENTITÁS MÉRÉSÉRE ALKALMAS SKÁLÁK TESZTELÉSÉRE}

Az alkalmazni kívánt skálákat 2011 novemberében, egy online megkérdezés keretében, hallgatói mintán teszteltük. A kérdőív kitöltése önkéntes volt, a hallgatók plusz pontokat szerezhettek a kutatáson való részvétellel. Az adatbázis tisztítását követően 299 válaszadó kérdőívét elemeztük.

A kutatás célja a környezethez való kötődés vizsgálatára eddig alkalmazott skálák tesztelése, valamint a kiválasztott Clayton-féle környezeti identitás skála alkalmazhatóságának, megbízhatóságának kiemelt vizsgálata volt. A korábban (5.3 fejezet) bemutatott és az előtanulmány során vizsgált skálák főbb jellemzőit az 6. táblázat foglalja össze.

A megfelelő skála kiválasztása érdekében a kutatás előtesztelése során a bemutatott skálák közül a hallgatói kutatás során lekérdeztük a Schultz féle INS skálát, a Nisbet Zelenski - Murphy NR skálát és a Clayton-féle EID skálát. A skálák kiválasztása során két szempontot vettem figyelembe. Az első, hogy explicit vagy implicit mérési módszert alkalmaz-e a skála. A környezeti identitás tudattalan lényegének értelmezése érdekében vizsgáltam az INS skálát, mint implicit mérésnek tekinthető vizsgálatot. A második szempont a skála dimenzionalitása volt. Az EID skála egydimenziós mérőeszköz a 
környezeti identitásra, míg az NR skála három dimenziót alkalmaz, az identifikáció mellett az attitüdöt és a viselkedési komponenst erősen hangsúlyozva vizsgálja a személyiség környezethez való kötődését.

\begin{tabular}{|c|c|c|c|}
\hline Skála & Év & Koncepció & Mérés módja \\
\hline $\begin{array}{l}\text { Schultz } \\
\text { Inclusion of nature in } \\
\text { the self (INS) }\end{array}$ & 2001 & $\begin{array}{l}\text { Aron (1992) skálájának adaptálása, a } \\
\text { természet és az egyén közötti } \\
\text { kapcsolat szorosságának vizsgálatára. }\end{array}$ & Implicit, 1 állítás \\
\hline $\begin{array}{l}\text { Clayton } \\
\text { Environmental } \\
\text { Identity (EID) }\end{array}$ & 2003 & $\begin{array}{l}\text { A természet szerepét és hatásának } \\
\text { mértékét vizsgálja az egyén } \\
\text { öndefiniálásában. Kognitív, affektív } \\
\text { és érzelmi szempontokat is vizsgál. } \\
1 \text { dimenziós }\end{array}$ & Explicit, 24 állítás \\
\hline $\begin{array}{l}\text { Schultz } \\
\text { IAT - Nature }\end{array}$ & 2004 & $\begin{array}{l}\text { Implicit mérési eszközök közé } \\
\text { tartozik. A természethez illetve az } \\
\text { épített környezethez való kötödés } \\
\text { erősségét vizsgálja. }\end{array}$ & $\begin{array}{l}\text { Implicit } \\
\text { Asszociációs Teszt }\end{array}$ \\
\hline $\begin{array}{l}\text { Mayer - Frantz } \\
\text { Connectedness to } \\
\text { Nature (CNS) }\end{array}$ & 2004 & $\begin{array}{l}\text { A természethez való érzelmi kötődést } \\
\text { vizsgálja a skála. } \\
1 \text { dimenziós }\end{array}$ & Explicit, 14 állítás \\
\hline $\begin{array}{l}\text { Nisbet - Zelenski - } \\
\text { Murphy } \\
\text { Nature Relatedness } \\
\text { Scale (NR) }\end{array}$ & 2009 & $\begin{array}{l}\text { A természethez kötődő személyiség } \\
\text { vizsgálata. } \\
\text { A természethez való kötődés érzelmi, } \\
\text { kognitív és a tapasztalati aspektusát is } \\
\text { figyelembe veszi. } \\
3 \text { dimenziós }\end{array}$ & Explicit, 21 állítás \\
\hline $\begin{array}{l}\text { Clayton } \\
\text { Environmental } \\
\text { Identity (EID), rövid } \\
\text { változat }\end{array}$ & 2011 & $\begin{array}{l}\text { A természet szerepének és hatásának } \\
\text { mértékét vizsgálja az egyén } \\
\text { öndefiniálásában. Kognitív, affektív } \\
\text { és érzelmi szempontokat is vizsgál. } \\
1 \text { dimenziós }\end{array}$ & Explicit, 11 állítás \\
\hline
\end{tabular}

6. táblázat: A természet és egyén közötti kapcsolatot vizsgáló skálák összefoglalása Forrás: saját szerkesztés

\subsubsection{AZ INS SKÁLA VIZSGÁLATA}

A válaszadók kevéssé érzik szorosnak kapcsolatukat a természettel. A skála átlaga $M=3,54$ lett, és ahogy az 9. ábrán látható, a válaszadók $82 \%$-a választotta a félig átfedő, vagy annál gyengébb kapcsolatot reprezentáló köröket.

Az eredmények azt mutatják, hogy az implicit mérés esetében az egyén és a környezet kapcsolatát gyengébbnek jelzik a válaszadók, mint az explicit mérések esetében. Ez az eredmény azon alapulhat, hogy a környezettudatosság olyan hívó szóvá vált napjainkban, amelyet rendszeresen hallunk, emiatt a társadalmi norma részévé vált és a társadalmi nyomás enyhén, de megjelenik a válaszokban. 


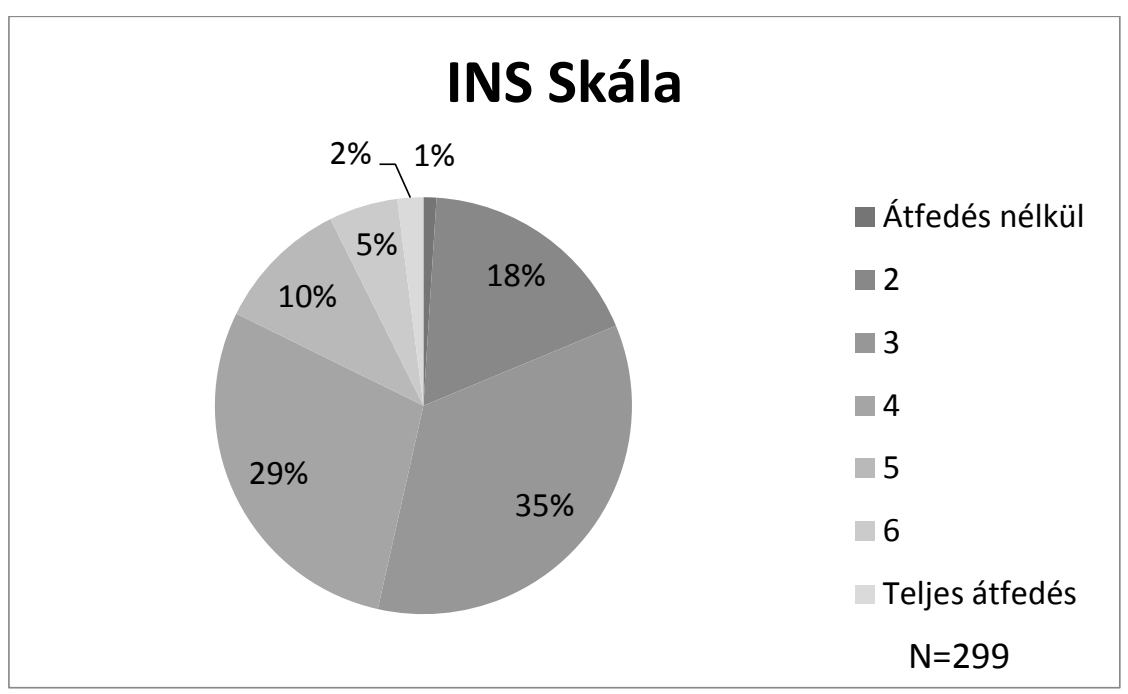

10. ábra: Az INS skála értékének eloszlása

Forrás: saját szerkesztés

\subsubsection{AZ NR SKÁLA VIZSGÁLATA}

Az NR skála 21 állításból áll, amelyek közül a 2, 3, 10, 11, 13, 14, 15, és a 18-as fordított állítások. A legmagasabb átlagot a természettel való identifikációt jelentő állítások kapták (Még a város közepén is észreveszem a természetet magam körül. $M=3,67$ ), ezt követik a környezeti aggodalomhoz kötődő állítások (lásd: melléklet). A válaszadók a legkevésbé azzal értettek egyet, hogy a természetvédelem felesleges lenne $(M=1,66)$.

A skála értékét (score) a szerzők az egyes állításokra adott értékek összátlagaként mérik, így minden egyén 1-5-ig terjedő értéket kaphat. A teljes skála érték átlaga 3,10, az NRSzelf érték átlaga 2,88, az NR-Perspektíva érték átlaga 3,64 míg az NR-Tapasztalat átlaga 2,81. Ebből is látható, hogy a környezeti attitüdöt jelképező NR-Perspektíva tekinthető a legfontosabbnak a mintán.

A skála megbízhatóságának ellenőrzésére alkalmas a belső konzisztenciát mérő Cronbach-alfa. Ennek az értéke a teljes skála esetében $\alpha=0,840$ volt, amely megfelel az elvárt 0,7-0,9 közötti optimális értéknek (Nunnally, 1967). Az alskálák esetében azonban az értékek nem elégségesek. Az NR-Szelf alskála értéke $\alpha=0,393$, az NR-Perspektíva esetében $\alpha=0,445$. Elfogadható érték egyedül az NR-Tapasztalat alskála esetében kaptunk, $\alpha=0,820$.

A skála dimenzióinak ellenőrzésére a szerzőkhöz hasonlóan exploratív faktorelemzést végeztem, maximum likelihood módszerrel és promax rotálással. A faktorelemzés 
eredménye 4 faktor lett. A várt 3 dimenzió nem jelent meg tisztán a mintán mért adatokban. A megbízhatósági elemzések és a dimenziók nem egyértelmü megjelenése miatt a skála alkalmazásának elvetése mellett döntöttem.

\subsubsection{AZ EID SKÁLA VIZSGÁLATA}

A megkérdezés során a Clayton-féle Környezeti Identitás skála rövidített változatát használtam. A skála leíró statisztikáit a 7. táblázat tartalmazza. A skála 11 állításból áll, amelyeket a szerző 7-fokú Likert-skálán javasol mérni.

A válaszadók leginkább az ideológiai egyetértés állításával, a természet megismerésének gyermeknevelésbe való beépítésének fontosságával értettek leginkább egyet $(M=5,99)$, ami a jövő generáció miatti aggodalmat is jelképezi. A saját felelősségteljes viselkedés követésével azonban már alacsonyabb volt az egyetértés $(M=4,54)$. Legkevésbé jellemző a természetben eltöltött idő volt $(M=3,74)$, illetve az anyagi vagy kényelmi szempontok, ráfordítások támogatása $(\mathrm{M}=4,01)$.

\begin{tabular}{|c|c|c|c|}
\hline EID skála & $\mathbf{N}$ & $\mathbf{M}$ & SD \\
\hline $\begin{array}{l}\text { Sok időt töltök természeti környezetben (erdö, hegyvidék, puszta, tópart, } \\
\text { tengerpart). }\end{array}$ & 299 & 3,74 & 1,490 \\
\hline Úgy tekintek magamra, mint aki a természet része, nem független tőle. & 299 & 4,26 & 1,736 \\
\hline $\begin{array}{l}\text { Ha lenne elég időm vagy pénzem, egy részét biztosan arra szánnám, hogy } \\
\text { környezetvédelmi ügyekkel foglalkozzam. }\end{array}$ & 299 & 4,01 & 1,771 \\
\hline $\begin{array}{l}\text { Ha kiborultam, vagy csak stresszes vagyok, segít jobban érezni magam, ha kis időt a } \\
\text { szabadban tölthetek élvezve a természetet. }\end{array}$ & 299 & 4,96 & 1,718 \\
\hline Érzem, hogy sok közös vonás van bennem és más élőlényekben. & 299 & 4,00 & 1,798 \\
\hline $\begin{array}{l}\text { A Földdel szembeni felelősségteljes viselkedés, azaz a fenntartható életmód } \\
\text { követése része az erkölcsi kódexemnek. }\end{array}$ & 299 & 4,54 & 1,533 \\
\hline $\begin{array}{l}\text { Minden gyermek nevelésének fontos része kellene, hogy legyen a természet } \\
\text { világának megismerése. }\end{array}$ & 299 & 5,99 & 1,173 \\
\hline $\begin{array}{l}\text { Inkább élnék egy szép kilátással rendelkező kisebb szobában vagy házban, mint egy } \\
\text { olyan szobában, vagy házban, amely nagyobb, de már épületekre néz. }\end{array}$ & 299 & 5,49 & 1,600 \\
\hline $\begin{array}{l}\text { Úgy érezném, hogy az életem egy fontos része hiányozna, ha nem tudnék időről- } \\
\text { időre kimenni a szabadba és élvezni a természetet. }\end{array}$ & 299 & 5,52 & 1,544 \\
\hline $\begin{array}{l}\text { Még nem láttam olyan müvészeti alkotást, amely annyira gyönyörü lenne, mint a } \\
\text { természet olyan csodái, mint a naplemente vagy egy hegylánc. }\end{array}$ & 299 & 4,76 & 1,848 \\
\hline Úgy érzem, spirituális feltöltődést jelent számomra a természet élménye. & 299 & 4,49 & 1,777 \\
\hline
\end{tabular}

7. táblázat: Az EID skála leíró statisztikái

Forrás: saját szerkesztés

A válaszadók környezeti identitásának erősségét a skála értéke adja meg. A skálaérték 11-77 között mozoghat, ahol 77-es értéket az erős környezeti identitással rendelkező 
személy kap. A skálaérték átlaga 51,76, ami a közepesnél kissé erősebb kötődést jelez a természet felé.

A skála megbízhatóságának elemzéséhez vizsgáltam az állítások egymással mért korrelációját. Az értékek minden esetben meghaladják a minimum 0,3-as értéket (lásd 8. táblázat). A Cronbach-alfa értéke szintén megfelelő, $\alpha=0,881$.

\begin{tabular}{|c|c|c|c|}
\hline EID skála állításai & $\begin{array}{l}\text { Átlag, a } \\
\text { tétel törlése } \\
\text { esetén }\end{array}$ & $\begin{array}{c}\text { Tétel - skála } \\
\text { korreláció }\end{array}$ & $\begin{array}{c}\alpha, \text { a tétel } \\
\text { törlése } \\
\text { esetén }\end{array}$ \\
\hline $\begin{array}{l}\text { Sok időt töltök természeti környezetben (erdő, } \\
\text { hegyvidék, puszta, tópart, tengerpart). }\end{array}$ & 48,02 &, 567 &, 872 \\
\hline $\begin{array}{l}\text { Úgy tekintek magamra, mint aki a természet része, nem } \\
\text { független töle. }\end{array}$ & 47,50 & ,716 & ,862 \\
\hline $\begin{array}{l}\text { Ha lenne elég időm vagy pénzem, egy részét biztosan } \\
\text { arra szánnám, hogy környezetvédelmi ügyekkel } \\
\text { foglalkozzam. }\end{array}$ & 47,75 &, 562 & ,873 \\
\hline $\begin{array}{l}\text { Ha kiborultam, vagy csak stresszes vagyok, segít } \\
\text { jobban érezni magam, ha kis időt a szabadban tölthetek } \\
\text { élvezve a természetet. }\end{array}$ & 46,80 & ,708 &, 863 \\
\hline $\begin{array}{l}\text { Érzem, hogy sok közös vonás van bennem és más } \\
\text { élőlényekben. }\end{array}$ & 47,76 &, 563 &, 873 \\
\hline $\begin{array}{l}\text { A Földdel szembeni felelösségteljes viselkedés, azaz a } \\
\text { fenntartható életmód követése része az erkölcsi } \\
\text { kódexemnek. }\end{array}$ & 47,22 &, 581 &, 872 \\
\hline $\begin{array}{l}\text { Minden gyermek nevelésének fontos része kellene, } \\
\text { hogy legyen a természet világának megismerése. }\end{array}$ & 45,77 & ,596 & ,872 \\
\hline $\begin{array}{l}\text { Inkább élnék egy szép kilátással rendelkező kisebb } \\
\text { szobában vagy házban, mint egy olyan szobában, vagy } \\
\text { házban, amely nagyobb, de már épületekre néz. }\end{array}$ & 46,27 & ,442 &, 880 \\
\hline $\begin{array}{l}\text { Úgy érezném, hogy az életem egy fontos része } \\
\text { hiányozna, ha nem tudnék időről-időre kimenni a } \\
\text { szabadba és élvezni a természetet. }\end{array}$ & 46,24 &, 713 &, 863 \\
\hline $\begin{array}{l}\text { Még nem láttam olyan müvészeti alkotást, amely } \\
\text { annyira gyönyörü lenne, mint a természet olyan csodái, } \\
\text { mint a naplemente vagy egy hegylánc. }\end{array}$ & 47,01 & ,432 &, 883 \\
\hline $\begin{array}{l}\text { Úgy érzem, spirituális feltöltődést jelent számomra a } \\
\text { természet élménye. }\end{array}$ & 47,27 & ,704 &, 863 \\
\hline
\end{tabular}

8. táblázat: Az EID skála belső konzisztenciája

Forrás: saját szerkesztés

A skála, Clayton (2003) szerint egydimenziós, annak ellenére, hogy a környezeti identitást több szempont alapján méri. A dimenziók számának ellenőrzésére főkomponens elemzést végeztem.

A rotálás nélküli fökomponens elemzés eredménye egy faktor. A korrelációs mátrix vizsgálatával megállapítottam, hogy az állítások szignifikáns, közepes erősségü 
korrelációt mutatnak, tehát a faktorelemzés elvégezhető. A Bartlett-teszt eredménye ( $<<0,000)$ alapján a nullhipotézis elvethetö, a KMO - teszt értéke 0,901, így a faktorelemzés eredménye elfogadható. A faktor a variancia 47,053 \%-át magyarázza. A hüvelykujj szabály szerint az a főkomponens elemzés fogadható el, amely az információk legalább felét megőrzi, azonban ez függ a változók számától is. 11 állítás esetében a 47\% határesetnek tekinthető (Székelyi és Barna, 2008).

\begin{tabular}{|c|c|}
\hline & Komponens \\
\hline Sok időt töltök természeti környezetben (erdő, hegyvidék, puszta, tópart, tengerpart). & 662 \\
\hline Úgy tekintek magamra, mint aki a természet része, nem független tőle. & ,786 \\
\hline $\begin{array}{l}\text { Ha lenne elég időm vagy pénzem, egy részét biztosan arra szánnám, hogy } \\
\text { környezetvédelmi ügyekkel foglalkozzam. }\end{array}$ & ,644 \\
\hline $\begin{array}{l}\text { Ha kiborultam, vagy csak stresszes vagyok, segít jobban érezni magam, ha kis időt a } \\
\text { szabadban tölthetek élvezve a természetet. }\end{array}$ & ,788 \\
\hline Érzem, hogy sok közös vonás van bennem és más élőlényekben. & 651 \\
\hline $\begin{array}{l}\text { A Földdel szembeni felelősségteljes viselkedés, azaz a fenntartható életmód követése } \\
\text { része az erkölcsi kódexemnek. }\end{array}$ & ,664 \\
\hline $\begin{array}{l}\text { Minden gyermek nevelésének fontos része kellene, hogy legyen a természet világának } \\
\text { megismerése. }\end{array}$ & 679 \\
\hline $\begin{array}{l}\text { Inkább élnék egy szép kilátással rendelkező kisebb szobában vagy házban, mint egy } \\
\text { olyan szobában, vagy házban, amely nagyobb, de már épületekre néz. }\end{array}$ & ,532 \\
\hline $\begin{array}{l}\text { Úgy érezném, hogy az életem egy fontos része hiányozna, ha nem tudnék időről-időre } \\
\text { kimenni a szabadba és élvezni a természetet. }\end{array}$ & ,784 \\
\hline $\begin{array}{l}\text { Még nem láttam olyan müvészeti alkotást, amely annyira gyönyörü lenne, mint a } \\
\text { természet olyan csodái, mint a naplemente vagy egy hegylánc. }\end{array}$ &, 512 \\
\hline Úgy érzem, spirituális feltöltődést jelent számomra a természet élménye. & ,773 \\
\hline
\end{tabular}

9. táblázat: Az EID skálára végzett főkomponens-elemzés eredménye Forrás: saját szerkesztés

Ha a 10. állítást kivesszük, 49,538\%-ra emelkedik a magyarázott variancia, ha pedig a 8 . állítást is kivesszük 52,371\%-ra emelkedik. A két állítás a természet esztétikai, művészeti értékét hangsúlyozza. Az eredmények alapján ez a szempont kissé eltávolodik a többi állítástól, amelyek a természettel való szorosabb kapcsolatot jelenítik meg.

Az INS skálával történő összevetés eredménye közepesen erős kapcsolatot mutat $(\mathrm{r}=0,566)$. A két skála tehát hasonló koncepciót mér.

Összefoglalva elmondható, hogy az EID skála vizsgálatának eredménye igazolja annak egydimenziós felépítését, és a megbízhatósági vizsgálatok eredményei támogatják a skála 
további alkalmazását. Az INS és az NR skálával történő összevetés alapján a kutatás következő fázisához az EID skála alkalmazását választottam. Egyrészt, mert az alkalmazott implicit mérőeszköz, az INS skála megbízhatósága az egy állítás miatt nehezen vizsgálható, másrészt mert az erős korreláció azt jelzi, hogy hasonló koncepciót mér a két skála.

Az NR skála esetében a várt három dimenzió a hallgatói mintán nem jelent meg tisztán. A teljes lakosság mintáján várakozásaim szerint hasonló eredmények jelennének meg, a dimenziók tisztább elkülönülése véleményem szerint esetleg egy környezettudatos, elkötelezett fogyasztói csoport vizsgálata esetén lenne várható. Ennek következtében a környezeti identitást célorientáltan mérő EID skála alkalmazása mellett döntöttem, és az NR skála alskáláit más validált skála alkalmazásával helyettesítem, mint a környezeti attitüd mérésére használt, az NR-Perspektíva alskálával erősen korreláló (Nisbet és tsai., 2009) NEP skála. 


\section{AZ EMPIRIKUS KUTATÁS TERVE}

Disszertációm során a környezettudatosság iránti elköteleződés egy lehetséges útját, a környezeti identitás erősítését, és a valós viselkedésre gyakorolt hatását vizsgálom.

A kutatás célja, hogy meghatározza a környezeti identitás környezettudatos viselkedésre gyakorolt hatását, valamint hogy elemezze a környezeti identitás hatására megjelenö különbségeket. A környezeti identitás és a környezetbarát viselkedés kapcsolatának elemzése során a szakirodalom által kiemelten kezelt, a környezetbarát fogyasztói magatartás modellekben alkalmazott pszichográfiai tényezők szerepét is vizsgálom, mint a környezeti attitüd, környezeti aggodalom, személyes norma és az értékek.

A 6 fejezetben bemutatásra kerültek a környezettudatos viselkedés vizsgálatára alkalmazható főbb modellek. A kutatás célja, hogy a környezeti identitás viselkedésre gyakorolt hatását teljes körüen vizsgálja és a kapcsolatot mediáló változókat egy konceptuális modellbe illessze. A környezeti identitás személyes pszichográfiai tényező, amely feltételezi, hogy az egyén egységet érez a természettel, és figyelembe veszi a döntései során a természet és a közösség érdekeit is. Ez alapján kutatásom az internalista modellekre, azon belül is a proszociális motivációkat hangsúlyozó modellekre alapoz. Disszertációmban Stern (1999) Érték-Hiedelem-Norma modelljét veszem kiindulópontnak.

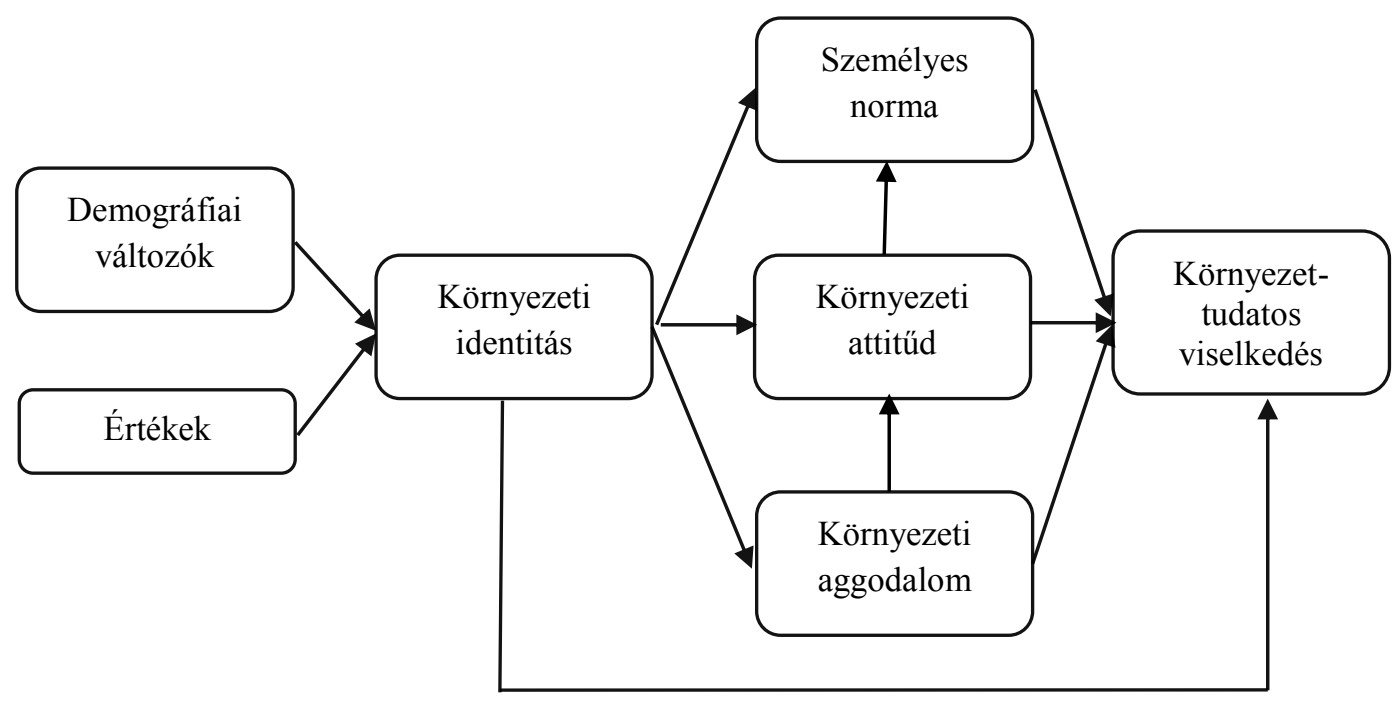

11. ábra: A kutatás elméleti modellje

Forrás: saját szerkesztés 
A modell alapfeltevése, hogy a környezeti identitás kialakulása szükséges eleme a környezettudatos viselkedés iránti elköteleződésnek, mert az erősebb környezeti identitással rendelkező egyének több környezetbarát cselekvést végeznek (Clayton, 2003). Az értékek az egyén kognitív rendszerében központi helyet foglalnak el, stabil személyiségjellemzők, amelyek hatást gyakorolnak a környezeti identitás kialakulására, valamint az attitüdre és a viselkedésre is (Homer és Kahle, 1988; Kamakura és Novak, 1992). Jelen modellben az értéket mint az identitást meghatározó tényezőt vesszük figyelembe.

A modell második része a Schwartz (1977) és Stern - féle (1999) norma aktiválás viselkedés-előmozdító hatásán alapul. A környezeti attitüd, a környezet iránti aggodalom (vö. bioszférikus aggodalom, 3.4.2 fejezet) kialakulása elősegíti a személyes norma aktiválódását és a viselkedésre kifejtett hatásának megjelenését.

Alapfeltevésem szerint tehát a környezeti identitás egy olyan kiinduló tényező, amelynek erős hatása van a viselkedésre közvetlenül is és a környezeti attitüdön, környezeti aggodalmon és a normán keresztül is.

\subsection{KUTATÁSI KÉRDÉSEK ÉS HIPOTÉZISEK}

Az általam felállított elméleti modell (11. ábra) a szakirodalom-feldolgozáson és az elmúlt években a témában végzett primer kutatások eredményein alapul. A környezettudatos viselkedés vizsgálatára több elméleti modellt is teszteltek, azonban a környezeti identitást jelen formában még nem vizsgálta részletesen a szakirodalom az alapvető meghatározó pszichográfiai konstrukciók összefüggéseiben. A modell leggyakrabban alkalmazott környezettudatos viselkedés kialakulásának meghatározó pszichográfiai tényezőit tartalmazza, célja a környezeti identitás koncepció vizsgálatának rendszerbe foglalása.

\section{Kutatási kérdésem: Melyek a főbb meghatározó tényezői a környezetbarát viselkedésnek, és milyen hatása van kiemelten a környezeti identitásnak?}

A kutatási kérdéshez kapcsolódóan alkérdéseket fogalmaztam meg:

1. Melyek a környezeti identitás mérésének lehetséges módszerei?

2. Milyen tényezők vannak hatással a környezeti identitás erősségére? 
3. Milyen irányú és erősségü a környezeti identitás hatása a környezetbarát viselkedésre? Van-e közvetlen hatása a környezeti identitásnak, és ha igen, mely pszichográfiai tényezők mediáló hatását kell figyelembe venni?

A kutatási kérdések megválaszolására az előtanulmányokra építve két további kutatást végeztem.

Első kutatás feladata a környezeti identitás eltérő mérési módszerei közti eltérések elemzése. Az előtanulmányok során összehasonlítottam a lehetséges explicit mérési eszközöket, majd az eredményekre alapozva a Clayton-féle Környezeti Identitás skálát választottam a disszertációm kvantitatív szakaszához.

A környezeti identitás vizsgálatát a szakirodalom az explicit mérési lehetőségek mellett implicit vizsgálattal is javasolja mérni (lásd: 5.3 fejezet). Az implicit mérések mögött az a feltételezés húzódik meg, hogy a környezeti identitás egy nem tudatos koncepció, amelyet nem lehet önelemzés által meghatározni (Schultz és tsai., 2004; Schultz és Tabanico, 2007).

Disszertációm első kutatása során elemzem az explicit és az implicit mérési lehetőségek megbízhatóságát és a valós viselkedéssel való kapcsolatukat. A környezeti identitást mint tudattalan koncepciót tekintve az alábbi feltevésből indulok ki:

\section{Az implicit környezeti identitás pozitív hatása a környezettudatos fogyasztói viselkedésre erősebb, mint az explicit mérésű identitásnak.}

Függő változó: környezetbarát magatartás

mérése: Roberts-féle Környezettudatos fogyasztói magatartás skála (Environmentally Conscious Consumer Behaviour Scale), (Roberts és Bacon, 1997)

Független változó 1: a Környezeti identitás

mérése: Clayton-féle Környezeti Identitás Skála (Clayton, 2003),

Független változó 2: a Természethez való kötődés, IAT-Nature

mérése: IAT-Nature D-mérés értéke (Schultz és tsai., 2004)

A második kutatás a környezeti identitás és a környezetbarát viselkedés kapcsolatának a kvantitatív vizsgálatára fókuszál. A bemutatott modellem alapján az alábbi kutatási kérdéseket és hipotéziseket fogalmaztam meg:

A környezeti identitás a természet és az egyén kapcsolatát jelenti, annak az erősségét, hogy mennyire része a természet az egyén énképének. Az egyén számára annál fontosabb 
a természet, minél erősebb a környezeti identitása. Az erős környezeti identitás aktívabb környezetbarát viselkedést indukál (Clayton, 2003; Olivos és Aragonés, 2011; Olivos és tsai., 2011). Ez alapján:

H1: A környezeti identitás pozitívan hat a környezetbarát magatartásra. Azaz minél erősebb környezeti identitással rendelkezik az egyén, annál több környezetbarát viselkedést végez.

Függő változó: környezetbarát magatartás mérése: Kaiser és Wilson-féle Általános Környezetbarát Viselkedés Skála (GEB), (Kaiser és Wilson, 2004)

Független változó: a környezeti identitás mérése: Clayton-féle Környezeti Identitás Skála (Clayton, 2003)

A környezeti identitás koncepció vizsgálata során a demográfiai változók hatását is érdemes és szükséges vizsgálni. A demográfiai változók környezeti identitásra gyakorolt hatására a tipikus környezettudatos fogyasztó demográfiai jellemzéséből következtethetünk (Diamantopoulos és tsai., 2003; Roberts, 1996). A környezetbarát fogyasztó demográfiai jellemzésére már az 1970-es évek végén voltak kutatások, a 2000es években a hangsúly azonban eltolódott a társadalmi és személyes tényezők irányába, illetve a komplex modellek alkotása felé (Kilbourne és Beckmann, 1998). A témakör kutatása azonban a komplexebb kutatások keretében újra létjogosultságát nyerte, mert a demográfiai változók eltérő hatással vannak a személyes tényezőkre, másképp hat például az életkor a környezeti attitüdre, mint a valós viselkedésre (Diamantopoulos és tsai., 2003). Erre alapozva érdemes vizsgálni, hogy a környezeti identitás esetében mely tényezők milyen irányultsággal válnak mérhető hatásúvá.

H2a: Az iskolai végzettség pozitív hatással van a környezeti identitásra, azaz minél magasabb az egyén iskolai végzettsége, annál erősebb környezeti identitással rendelkezik.

Függő változó: a környezeti identitás mérése: Clayton-féle Környezeti Identitás Skála (Clayton, 2003)

Független változó: iskolai végzettség

H2b: A nők erősebb környezeti identitással rendelkeznek.

Függő változó: a környezeti identitás

mérése: Clayton-féle Környezeti Identitás Skála (Clayton, 2003)

Független változó: nem 
H2c: A jövedelem pozitív hatással van a környezeti identitásra. Azaz minél magasabb az egyén jövedelme, annál erősebb környezeti identitással rendelkezik.

Függő változó: a környezeti identitás

mérése: Clayton-féle Környezeti Identitás Skála (Clayton, 2003)

Független változó: háztartás egy före jutó jövedelme

H2d: A kornak negatív hatása van a környezeti identitásra. Azaz a fiatalabb személyek erősebb környezeti identitással rendelkeznek.

Függő változó: a környezeti identitás

mérése: Clayton-féle Környezeti Identitás Skála (Clayton, 2003)

Független változó: válaszadó kora

Az értékek a társadalom és az egyén közötti kapcsolatot hangsúlyozzák (Beatty és tsai., 1985), mert az értékrend a kulturális szocializáció által meghatározott, illetve az egyén tapasztalataitól is függ. Az értékek az attitűddel szemben erősebb viselkedés meghatározó szereppel rendelkeznek (Sudbury-Riley és tsai., 2014). Az értékeket többféleképpen lehet csoportosítani. A kontroll helye szerint megkülönböztethetünk belső és külső értékeket (Kahle, 1983). A környezeti identitás akkor válik erősebbé, ha internalizálta az egyén a környezettel való kapcsolatát, azaz belső indíttatásból viselkedik. Ebből következtetve az alábbi hipotézisből indulunk ki:

H3: A környezeti identitásra a belső értékeknek erősebb hatása van, mint a külső értékeknek.

Függő változó: a környezeti identitás

mérése: Clayton-féle Környezeti Identitás Skála (Clayton, 2003)

Független változó: értékek

mérése: List of Value értékskála (Kahle, 1983)

A disszertáció következő kutatási kérdése a környezeti aggodalom, a környezeti attitűd, és a természet - egyén kapcsolata között fennálló viszonyra vonatkozik. Schultz (2004) szerint az egyén természethez való kötődésének mértéke, hogy milyen mélységben érzi önmagát a természet részének, meghatározza a kialakuló aggodalom típusát és azokat a helyzeteket, amelyben cselekvésre indít. Schultz két szélsőséges egyéni gondolkodást határozott meg. Az egyik szélsőség az egyén, aki teljesen különállónak gondolja magát a természettől, az embert a természet törvényei alól kivételnek tekinti, és felsőbbrendűnek 
a növényekhez és állatokhoz képest; rá az egoista aggodalom lesz jellemző. Ezzel szemben a másik szélsőség az egyén, aki ugyanannyira a természet részének tartja magát, mint minden más élőlényt, és úgy véli, hogy az emberekre a növényekre és állatokra ugyanazoknak a jogoknak kell vonatkoznia. Rájuk a bioszférikus aggodalom jellemző (Schultz, 2001, Schultz és mtsai., 2005). Gosling és Williams (2010) kutatása egy speciális szegmensen, a farmereken igazolta, hogy a környezeti aggodalomnak mediáló hatása van a környezeti kötődés és a helyi vegetáció megóvása közötti kapcsolatra. Erre az eredményre alapozva vizsgáljuk a kérdést általános lakossági mintán, tágabb viselkedésre vonatkozóan:

\section{H4a: A környezeti identitásnak pozitív hatása van a környezeti aggodalomra.}

Függő változó: a környezeti aggodalom mérése: Környezeti aggodalom skála (Schultz, 2001)

Független változó: a környezeti identitás mérése: Clayton-féle Környezeti Identitás Skála (Clayton, 2003)

H4b: A környezeti identitásnak a bioszférikus aggodalomra van a legerősebb hatása az egoista és az altruista aggodalommal összevetve. Azaz az erősebb környezeti identitással rendelkező egyénekre a bioszférikus aggodalom a jellemző, míg az alacsonyabb környezeti identitás értékkel rendelkező egyénekre az egoista aggodalom jellemző.

Függő változó: a környezeti aggodalom mérése: Környezeti aggodalom skála alskálái (Schultz, 2001)

Független változó: a környezeti identitás mérése: Clayton-féle Környezeti Identitás Skála (Clayton, 2003)

\section{H4c: A környezeti aggodalomnak pozitív hatása van a környezettudatos viselkedésre.}

Függő változó: környezetbarát magatartás mérése: Kaiser és Wilson-féle Általános Környezetbarát Viselkedés Skála (GEB), (Kaiser és Wilson, 2004)

Független változó: a környezeti aggodalom mérése: Környezeti aggodalom skála (Schultz, 2001) 
A környezeti attitüd (világnézet) azt vizsgálja, hogy milyen meggyőződései vannak az egyénnek a természettel kapcsolatban. A természetben való léthez kapcsolódó érzelmeket, a természethez való kötődést az attitűd skálák természetesen nem vizsgálják. A két koncepciót közösen vizsgáló kutatások azonban pozitív korrelációt tárnak fel a környezethez való kötődés és a környezeti attitüd között, mindamellett, hogy a fogalmak különállóságát is igazolják (Nisbet és tsai., 2009). A környezeti kötődést vizsgáló skálák emellett erősebb közvetlen kapcsolatot mutatnak a valós viselkedéssel, mint az attitüd, ezért modellemben az attitüd mediáló hatását vizsgálom a környezeti identitás és a környezetbarát viselkedés között.

\section{H5a: A környezeti identitásnak pozitív hatása van a környezeti attitüdre.}

Függő változó: a környezeti attitüd

mérése: Új Környezeti Paradigma Skála (NEP) (Dunlap és tsai., 2000)

Független változó: a környezeti identitás mérése: Clayton-féle Környezeti Identitás Skála (Clayton, 2003)

\section{H5b: A környezeti attitűdnek pozitív hatása van a környezettudatos viselkedésre.}

Függő változó: környezetbarát magatartás

mérése: Kaiser és Wilson-féle Általános Környezetbarát Viselkedés Skála (GEB), (Kaiser és Wilson, 2004)

Független változó: a környezeti attitüd mérése: Új Környezeti Paradigma Skála (NEP) (Dunlap és tsai., 2000)

A disszertáció elméleti modelljének utolsó eleme a személyes norma. Heberlein meghatározásában a személyes norma a morális attitüd belsővé tétele, amely a társadalmilag elfogadott normákból ered, de abban különbözik tőle, hogy a megsértésének a következményei az egyén identitásához kötött (Heberlein, 1977) . A személyes normák tehát internalizált társas normák (Schwartz és Howard, 1980). A normák vizsgálata kifejezetten akkor előnyös, ha a vizsgált viselkedéseknek morális vagy etikai dimenziója van (Davies és tsai., 2002). A környezettudatos viselkedés mindenképp ebbe a kategóriába tartozik. Davies és kollégái (2002) a személyes norma előrejelző hatásának pontos vizsgálatát javasolja (Davies és tsai., 2002), kutatásukban igazolva a személyes morális norma, felelősség érzés szerepét az újrahasznosítás esetében. Ez alapján a hipotézisem: 


\section{H6a: A környezeti identitásnak pozitív hatása van a személyes normára.}

Függő változó: személyes norma mérése: Stern-féle Személyes Norma Skála (Stern, 1999; Stern és tsai., 1999)

Független változó: a környezeti identitás mérése: Clayton-féle Környezeti Identitás Skála (Clayton, 2003)

\section{H6b: A személyes norma pozitívan hat a környezettudatos viselkedésre.}

Függő változó: környezetbarát magatartás

mérése: Kaiser és Wilson-féle Általános Környezetbarát Viselkedés Skála (GEB), (Kaiser és Wilson, 2004)

Független változó: személyes norma mérése: Stern-féle Személyes Norma Skála (Stern, 1999; Stern és tsai., 1999)

\subsection{ALKALMAZOTT KUTATÁSI MÓDSZEREK}

\subsubsection{IMPLICIT ASSZOCIÁCIÓS TESZT - NATURE}

Az első kutatási kérdés a környezeti identitás mérési módszereire vonatkozik, amely során az Implicit Asszociációs Teszt természet és egyén kapcsolatának vizsgálatára adaptált IAT-Nature tesztet alkalmaztam. Az IAT-Nature teszt implicit módon méri a természet és az én kapcsolatának közelségét úgy, hogy azt vizsgálja, hogy az egyén milyen gyorsan asszociál az énre vonatkozó szavak mellé természetre vagy épített környezetre vonatkozó szavakat. A tesztben két kategóriát alkalmazunk, az Én - Mások és a Természet - Épített környezet kategóriát (Schultz és tsai., 2004).

Az IAT-Nature kutatás 2013 év elején történt, hallgatói mintán. A hallgatók a Fogyasztói magatartás tantárgy keretén belül vehettek részt a kutatásban, a részvételt plusz ponttal értékeltük. A teszt elvégzése után a válaszadók egy rövid kérdöívet is kitöltöttek, amely tartalmazza a Clayton-féle Környezeti Identitás skálát (2003), valamint a Roberts - féle Környezettudatos fogyasztói magatartás skálát, a NEP környezeti attitűd skálát (Dunlap és tsai., 2000) valamint demográfiai kérdéseket.

A hipotézis vizsgálatára az IAT-Nature értékelésére alkalmas D-mérés illetve az EID skála érték és a környezetbarát viselkedések végzése közötti kapcsolatok erősségét vettettem össze. 


\subsubsection{A KÖRNYEZETI IDENTITÁS ÉS A KÖRNYEZETTUDATOS VISELKEDÉS KAPCSOLATÁNAK VIZSGÁLATA}

Az elméleti modellen alapuló hipotézisek megválaszolására kvantitatív kutatás készült a TÁMOP-4.2.1/B-09/1/KMR-2010-0005, Fenntartható fejlődés, élhető régió, élhető települési táj pályázati projektjének keretében.

Az adatfelvétel 2012 áprilisában zajlott. A kérdőív online (CAWI) megkérdezéssel készült. A minta elemszáma 954 fö, a minta reprezentatív a 15-69 év közötti, hazai rendszeres internetezőkre nem, kor, végzettség, településtípus és régió jellemzők mentén. A kérdőívben a disszertációmhoz tervezett változók mellett a környezettudatos fogyasztás szélesebb körü vizsgálatát végeztük a kollégáimmal (Hofmeister-Tóth és tsai., 2013).

Az adatok elemzése során a főbb célok:

- a Környezeti Identitás Skála konfirmatorikus faktorelemzéssel történő tesztelése;

- a környezeti identitás és a környezetbarát magatartás közötti kapcsolat vizsgálata;

○ a Környezeti Identitás és a Környezettudatos viselkedés kapcsolatát befolyásoló pszichográfiai tényezők összefüggéseit regressziós útmodell segítségével elemeztem. A tézistervezet során meghatározott strukturális modellezés módszertanát jelen kutatásban nem alkalmaztam, mivel a kutatás feltáró jellegü. A Környezeti Identitás erősen befolyásolt a kultúra és a társadalmi környezet által. Hazai környezetben általam ismert kutatás $^{20}$ még nem alkalmazta a koncepciót, ezért a pszichográfiai változókkal való kapcsolatok előzetes feltárása szükséges. Hair és munkatársainak (Hair és tsai., 2010) ajánlása alapján a strukturális modellezés módszerét kizárólag igazoló kutatásokban javasolt használni.

- a Környezeti Identitás erősségét meghatározó tényezők vizsgálata, kiemelten a demográfiai tényezők és az értékek hatásának értékelése. Az elemzéshez varianciaanalízist és lineáris regressziót végeztem.

Az alkalmazott kutatási módszereket a 10. táblázat foglalja össze.

\footnotetext{
${ }^{20}$ Nemzetközi kutatások is jellemzően egyetemista, illetve specifikus mintán vizsgálták.
} 


\begin{tabular}{|c|c|c|c|c|c|}
\hline Kutatási módszer & $\begin{array}{l}\text { Kutatási módszer } \\
\text { ismertetése }\end{array}$ & Válaszadók & $\begin{array}{l}\text { Minta } \\
\text { nagyság }\end{array}$ & $\begin{array}{l}\text { Adatfelvétel } \\
\text { időpontja }\end{array}$ & Elemzés, feldolgozás módja \\
\hline $\begin{array}{l}\text { Kvalitatív } \\
\text { előtanulmány| } \\
\text { természet } \\
\text { értelmezésének } \\
\text { vizsgálata }\end{array}$ & $\begin{array}{l}\text { Narratív elemzés, pozitív és } \\
\text { negatív természeti } \\
\text { élményekről szóló esszék } \\
\text { elemzése }\end{array}$ & $\begin{array}{l}\text { Elsőéves egyetemi } \\
\text { hallgatók (MA) }\end{array}$ & $\begin{array}{l}34 \text { fö }(68 \\
\text { esszé) }\end{array}$ & 2011 május & $\begin{array}{l}\text { Atlas Ti } 5.2 \text { kvalitatív elemző } \\
\text { szoftver, valamint IBM SPSS } \\
\text { szoftvercsomag segítségével }\end{array}$ \\
\hline $\begin{array}{l}\text { Kvantitatív } \\
\text { előtanulmány| } \\
\text { skálatesztelés }\end{array}$ & Online kutatás & $\begin{array}{l}\text { Harmadéves egyetemi } \\
\text { hallgatók (BA) }\end{array}$ & 299 fö & 2011 november & $\begin{array}{l}\text { IBM SPSS szoftvercsomag } \\
\text { segítségével }\end{array}$ \\
\hline $\begin{array}{l}\text { Implicit } \\
\text { Asszociációs } \\
\text { Teszt }\end{array}$ & $\begin{array}{l}\text { Az egyén és a természet } \\
\text { közötti kapcsolat implicit } \\
\text { mérése }\end{array}$ & $\begin{array}{l}\text { Másod- és harmadéves } \\
\text { egyetemi hallgatók } \\
\text { (BA) }\end{array}$ & 199 fö & 2012 december & $\begin{array}{l}\text { D-mérés, FreeIAT program } \\
\text { segítségével, valamint } \\
\text { IBM Slemzés } \\
\text { segítségével }\end{array}$ \\
\hline $\begin{array}{l}\text { Kvantitatív } \\
\text { kutatás } \\
\text { modellalkotás }\end{array}$ & $\begin{array}{l}\text { Online kutatás, országos, } \\
\text { reprezentatív minta }\end{array}$ & $\begin{array}{l}\text { Rendszeresen } \\
\text { internetező magyar } \\
\text { lakosság }\end{array}$ & 954 fö & 2012 április & $\begin{array}{l}\text { IBM SPSS és AMOS } \\
\text { szoftvercsomag segítségével }\end{array}$ \\
\hline
\end{tabular}

10. táblázat: Kutatási módszerek

Forrás: saját szerkesztés 


\section{IAT-NATURE ALKALMAZÁSA A TERMÉSZET ÉS AZ EGYÉN KAPCSOLATÁNAK VIZSGÁLATÁRA}

A primer kutatás célja az egyén és a természet kapcsolatára alkalmazható explicit és implicit kutatási módszerek összehasonlítása, valamint a környezeti attitűddel és a környezettudatos viselkedéssel való összefüggéseinek a vizsgálata volt.

Az adatfelvétel 2012 decemberében zajlott, a kutatásban a Budapesti Corvinus Egyetemen tanuló 199 hallgató vett részt.

\subsection{KUTATÁS ESZKÖZEINEK ÉS INGERANYAGAINAK BEMUTATÁSA}

A kutatás során a válaszadók elöször az IAT-Nature számítógépes implicit asszociációs tesztet töltötték ki, majd azt követően egy online kérdőívet, amely a környezeti attitüd, a környezeti identitás, és a környezettudatos viselkedés mérésére alkalmas explicit skálákat tartalmazott. Az explicit mérések között 3 skálát alkalmaztam:

- a környezeti attitűd mérésére az Új Környezeti Paradigma, a New Ecological Paradigm skálát (Dunlap és Van Liere, 1978; Dunlap és tsai., 2000);

- a környezeti identitás mérésére Clayton (2003) Környezeti Identitás skáláját (Clayton, 2003); valamint

- a környezettudatos fogyasztói magatartás mérésére a Roberts-féle Ecologically Conscious Consumer Behaviour (ECCB) skálát (Roberts és Bacon, 1997).

A természettel való kapcsolat implicit mérésére Schultz és munkatársai (2004) korábban bemutatott IAT- Nature tesztjét alkalmaztam, a FreeIAT szoftver segítségével. A teszt elején a válaszadók azt a felhívást kapták, hogy a feladat az összetartozó szavak minél gyorsabb összepárosítása. A folyamat 5 blokkból állt, mindegyikben 10-10 párosítással. 4 kategóriát használtam a blokkokban (Én, Nem Én, Természet és Épített környezet), a blokkok az alábbi felépítést követték:

- első párosítás: 10 feladat a Természet vagy Épített környezet értékelő attribútumhoz tartozó példaszavak párosítására. 
- második párosítás: 10 feladat az Én vagy Nem Én attitüdtárgyakhoz tartozó szavak szortírozására.

- harmadik párosítás: szintén 10 feladat, az első páros teszt, egyenes párosítással. Mind a 4 féle példa szortírozására, egy attitüdtárgy egy értékelő attribútummal kapcsolódik az egyik gombhoz, s a másik attitüdtárgy a másik értékelő attribútummal kapcsolódik a másik gombhoz. A kompatibilitás azt jelenti, hogy az Én és a Természet kategóriákat állítottuk szembe az Épített környezet és Nem Én kategóriákkal.

- negyedik párosítás: 10 feladat a Természet vagy Épített környezet értékelő attribútumhoz tartozó példaszavak párosítására, mint az első blokkban, de fordított billentyüzethasználattal.

- ötödik párosítás: 10 feladat, a második páros teszt, ellentétes párosítással. Mind a 4 féle példa szortírozására, egy attitűdtárgy egy értékelő attribútummal kapcsolódik az egyik gombhoz, s a másik attitüdtárgy a másik értékelő attribútummal kapcsolódik a másik gombhoz. A nem kompatibilis párosítás azt jelenti, hogy a billentyűhasználat a negyedik párosítás szerinti, valamint az Én és az Épített környezet kategóriákat állítottuk szembe a Természet és Mások kategóriákkal.

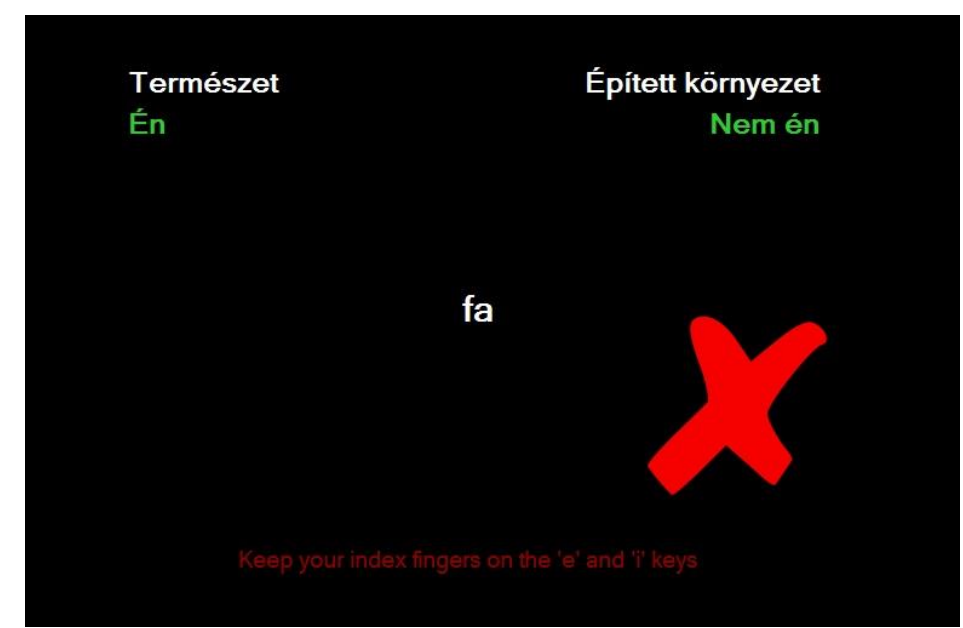

12. ábra: IAT-Nature teszt példa: kompatibilis, páros próba Forrás: FeeIAT program, saját kutatás

Az én és a természet közötti kapcsolat erősségét a kompatibilis és a nem kompatibilis páros tesztek asszociációs nehézségeinek a különbsége mutatja meg. Így ha az adott személynek a kognitív asszociációja a természettel erősebb, akkor az Én és a Természet kategóriákba tartozó szavak összekapcsolásakor könnyebben, azaz 
gyorsabban fogja teljesíteni a blokkot (3. párosítás), mint a nem kompatibilis párosítást. Ennek az ellenkezője lesz igaz arra a személyre, aki az épített környezethez kötődik jobban.

\subsection{A MinTA BEMUTATÁSA}

Az elemzésben azok a válaszadók vettek részt, akik a teljes kutatási folyamatot végigkövették, vagyis az explicit és az implicit mérésben is részt vettek. Az IATNature teszt elemzésének megkezdése előtt, a Greenwald és munkatársai (2003) által ajánlott továbbfejlesztett D-érték számításához a minta tisztítására volt szükség. A 10000 ms-nál nagyobb reakcióidejü próbákat eltávolítottam az elemzésből. Azokat a résztvevőket is kihagytam a vizsgálatból, akiknek minden próbáját figyelembe véve, a próbák több mint 10\%-ában kisebb volt a reakcióidő 300 msnál. Így a végső minta elemszám 196 fö lett.

A mintában a nők aránya magasabb (58,7\%), a jellemző lakhely Budapest, a válaszadók 66,8\%-a Budapesten lakik. Az egyetemi hallgatókból álló minta következtében leggyakrabban középfokú végzettséggel (86,7\%) rendelkeznek a válaszadók, és saját bevallásuk szerint az átlagnál kicsit jobb jövedelemmel rendelkeznek (55,6\%). A minta bemutatását a 11. táblázat részletezi.

\begin{tabular}{|l|l|c|c|}
\hline \multirow{4}{*}{ Nem } & Nö & Elemszám & $\%$ \\
\cline { 2 - 4 } & Férfi & 115 & 58,7 \\
\cline { 2 - 4 } & Összesen & 81 & 41,3 \\
\hline \multirow{5}{*}{ Lakhely } & Budapest & 196 & 100 \\
\cline { 2 - 4 } & Megyeszékhely & 131 & 66,8 \\
\cline { 2 - 4 } & Egyéb város & 23 & 11,7 \\
\cline { 2 - 4 } & Község, falu & 34 & 17,3 \\
\cline { 2 - 4 } & Összesen & 8 & 4,1 \\
\hline Iskolai végzettség & Középfok, érettségi & 196 & 100 \\
\cline { 2 - 4 } & Föiskola, alapszak & 170 & 86,7 \\
\cline { 2 - 4 } & Egyetem, mesterszak & 19 & 9,7 \\
\cline { 2 - 4 } & Összesen & 7 & 3,6 \\
\hline \multirow{5}{*}{ Életszínvonal } & Az átlagnál sokkal rosszabb & 7 & 100 \\
\cline { 2 - 4 } & Átlagos & 49 & 25,0 \\
\cline { 2 - 4 } & Az átlagnál valamivel jobb & 109 & 55,6 \\
\cline { 2 - 4 } & Az átlagnál sokkal jobb & 31 & 15,8 \\
\cline { 2 - 4 } & Összesen & 196 & 100 \\
\hline Életkor & Átlag & 21,55 & \\
\hline
\end{tabular}

11. táblázat: A minta demográfiai jellemzőinek a bemutatása

Forrás: saját kutatás 


\subsection{AZ IMPLICIT MÉRÉS EREDMÉNYEI}

Az IAT eredményeinek értékeléséhez Greenwald és munkatársai javaslatát használtam (részletesen lásd: Greenwald és tsai, 2003, valamint 5.3.2.1. fejezet).

Az IAT-hatás a 0,09-es átlaggal arra utal összességében, hogy a válaszadók átlagosan automatikus szinten a természeti környezetet és az épített környezetet majdnem azonos mértékben preferálják a válaszadási sebesség alapján $(\mathrm{M}=0,09 ; \mathrm{SD}=0,5578)$, amely azt jelenti, hogy az implicit kötődés ereje majdnem azonos a természeti és az épített környezet között. A D-értékek maximuma 2,03 volt, míg minimuma -1,33.

Azok az egyének kötődnek erősebben a természethez az épített környezettel szemben, akik pozitív D-értékkel rendelkeznek, míg a negatív D-értékkel rendelkezők az épített környezetet preferálják jobban. A válaszadók 36\%-a asszociálja az épített környezetet erősebben önmagával (D-érték < -0,1), 16\% preferenciája nagyjából semlegesnek tekinthető $(-0,1<$ D-érték $<0,1)$. A mintában $48 \%$ eltérő erősséggel, de a természeti környezetet érzi közelebb önmagához (D-érték $>0,1)$.

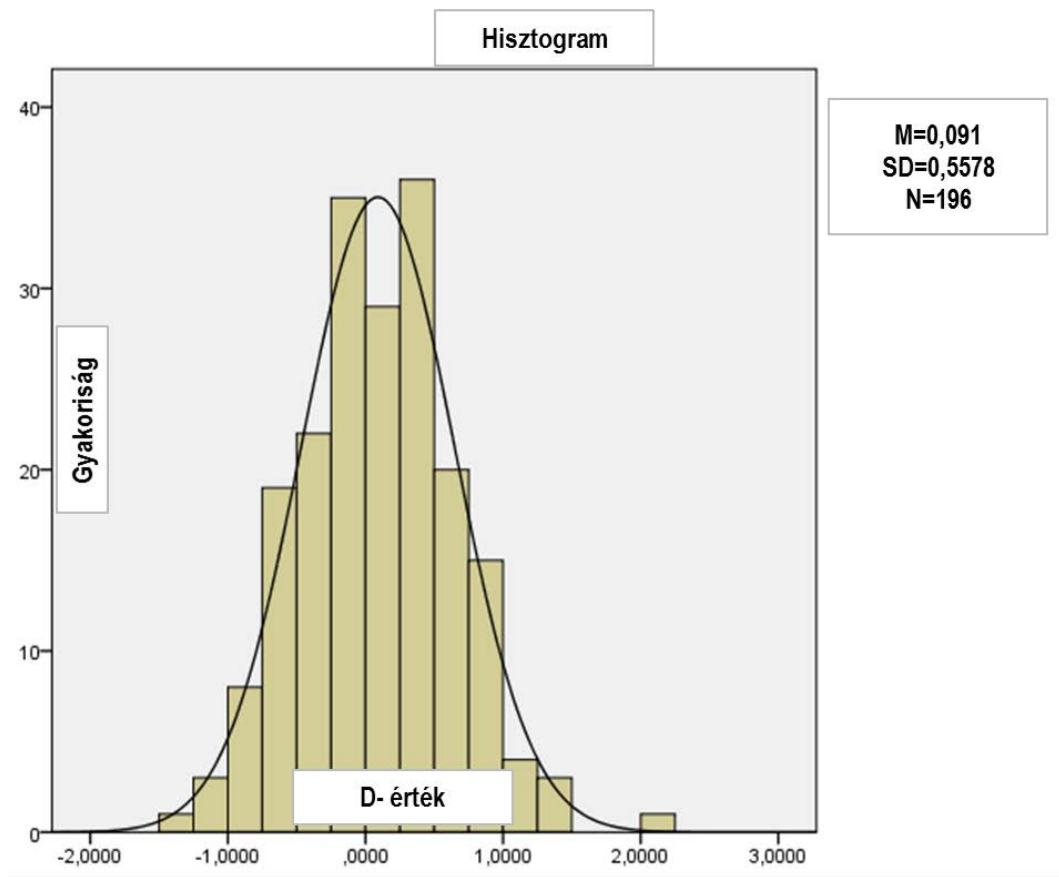

13. ábra: D- érték megoszlása Forrás: saját szerkesztés

Az eredmények összehasonlítása a nemzetközi kutatási eredményekkel azt mutatja, hogy a természeti környezet preferenciája alacsonyabb, mint hasonló kutatásokban, ahol 0,3 - 0,4 körüli D-értékeket mutattak ki a jelen kutatáshoz hasonló hallgatói 
mintákon. Az eredmények direkt összehasonlítása azonban az eltérő minták és az eltérő IAT-hatás számítási módszerek miatt nem egyértelmű (IAT- Nature kutatásokat bővebben lásd: Bruni és tsai., 2012; Bruni és Schultz, 2010; Schultz és tsai., 2004; Schultz és Tabanico, 2007).

A teszt belső megbízhatóságának vizsgálatára a D-értéket kiszámoltam a blokkok első 5 stimulusára, illetve második 5 stimulusára külön-külön, majd korrelációval vizsgáltam a kapcsolatot. Az eredmény szignifikáns, azonban csupán gyenge pozitív kapcsolat áll fenn $(\mathrm{r}(194)=0,201, \mathrm{p}=0,005)$, amely az eredmények körültekintő értelmezésére hívja fel a figyelmet.

A mintát vizsgálva, a demográfiai jellemzőket figyelembe véve, szignifikáns különbség figyelhető meg a férfiak és nők válaszai között $(F(1,194)=4,666, p=0,032)$. Az eredmények alapján a nőknek erősebb kapcsolata van a természettel, mint a mintában lévő férfiaknak $\left(\mathrm{M}_{\mathrm{nŏ}}=0,16, \mathrm{SD}_{\mathrm{nö}}=0,54 ; \mathrm{M}_{\mathrm{ffi}}=-0,01, \mathrm{SD}_{\mathrm{ffi}}=0,57\right)$. Ezek az eredmények összhangban vannak Schultz és munkatársai (2007) korábbi IAT-Nature kutatásaival is. Más demográfiai változóval nem találtunk szignifikáns kapcsolatot, ami a homogén mintajellemzőkkel indokolható.

\subsection{AZ EXPLICIT MÉRÉSEK EREDMÉNYEI}

Az Új Környezeti Paradigma, a NEP skála célja az „ökológiai világnézet” vizsgálata. A NEP skála az egyén meggyőződéseit méri a növekedés határainak eléréséről, a lehetséges ökokrízisről, és a természeti egyensúly törékenységéről. Emellett a világnézet része az egyén emberről és természetről való gondolkodásmódja is, mennyiben tartja a válaszadó az embert felsőbbrendűnek a növényekkel és állatokkal szemben, illetve mennyire hangsúlyozza az emberi kiváltságosságot. A NEP skála alkalmas a környezeti attitűd és egyéb szocio-ökonómiai változók vizsgálatára, mint a környezeti értékekkel való összekapcsolásra és következtetések levonására, illetve a környezetbarát viselkedéssel való kapcsolat vizsgálatára (Milfont és Duckitt, 2004; Sudbury-Riley és tsai., 2014).

A NEP skála értéke a negatív kérdések átalakítása után kapott értékek összegzését jelenti, minimum értéke 15, a maximuma pedig 75 pont lehet. A teljes mintára nézve kapott átlag 54,84 pont volt $(\mathrm{SD}=7,33)$, ami a korábbi hazai NEP kutatások 
(Hofmeister-Tóth és tsai., 2013) által kapott értékekhez hasonló (2010-ben M=54,53; 2012-ben M=58,51). A skála megbízhatóságának vizsgálatára a Cronbach Alfa mutatót használtam, melynek értéke $0,745(\mathrm{~N}=190)$, ami alapján a skála megfelelően erős belső konzisztenciát mutat (Nunnally, 1967). A demográfiai változókat vizsgálva a NEP esetében is szignifikáns különbség figyelhető meg a férfiak és nők válaszai között $(\mathrm{F}(1,188)=14,469, \mathrm{p}=0,000)$. A férfiak környezeti attitüdje kevésbé erős, mint a nőké $\left(\mathrm{M}_{\mathrm{nö}}=56,47, \mathrm{SD}_{\mathrm{nö}}=5,89 ; \mathrm{M}_{\mathrm{ffi}}=52,50, \mathrm{SD}_{\mathrm{ffi}}=8,52\right)$.

A kutatás során a Clayton-féle Környezeti Identitás skála rövidített változatát használtam (Clayton és tsai., 2011). A skála 11 állításból áll, amelyet 7 fokú Likert skálán mértem. A skála leíró statisztikáit a 12. táblázat tartalmazza.

\begin{tabular}{|l|c|c|}
\hline EID skála (N=196) & M & SD \\
\hline $\begin{array}{l}\text { Sok idöt töltök természeti környezetben (erdö, hegyvidék, puszta, tópart, } \\
\text { tengerpart). }\end{array}$ & 3,72 & 1,487 \\
\hline Úgy tekintek magamra, mint aki a természet része, nem független töle. & 4,47 & 1,570 \\
\hline $\begin{array}{l}\text { Ha lenne elég időm vagy pénzem, egy részét biztosan arra szánnám, hogy } \\
\text { környezetvédelmi ügyekkel foglalkozzam. }\end{array}$ & 4,25 & 1,752 \\
\hline $\begin{array}{l}\text { Ha kiborultam, vagy csak stresszes vagyok, segít jobban érezni magam, ha kis idöt } \\
\text { a szabadban tölthetek élvezve a természetet. }\end{array}$ & 5,13 & 1,765 \\
\hline Érzem, hogy sok közös vonás van bennem és más élőlényekben. & 3,65 & 1,725 \\
\hline $\begin{array}{l}\text { A Földdel szembeni felelösségteljes viselkedés, azaz a fenntartható életmód } \\
\text { követése része az erkölcsi kódexemnek. }\end{array}$ & 4,84 & 1,509 \\
\hline $\begin{array}{l}\text { Minden gyermek nevelésének fontos része kellene, hogy legyen a természet } \\
\text { világának megismerése. }\end{array}$ & 6,01 & 1,152 \\
\hline $\begin{array}{l}\text { Inkább élnék egy szép kilátással rendelkezö kisebb szobában vagy házban, mint } \\
\text { egy olyan szobában, vagy házban, amely nagyobb, de már épületekre néz. }\end{array}$ & 5,32 & 1,677 \\
\hline $\begin{array}{l}\text { Úgy érezném, hogy az életem egy fontos része hiányozna, ha nem tudnék időröl- } \\
\text { időre kimenni a szabadba és élvezni a természetet. }\end{array}$ & 5,41 & 1,501 \\
\hline $\begin{array}{l}\text { Még nem láttam olyan művészeti alkotást, amely annyira gyönyörü lenne, mint a } \\
\text { természet olyan csodái, mint a naplemente vagy egy hegylánc. }\end{array}$ & 4,65 & 1,985 \\
\hline Úgy érzem, spirituális feltöltődést jelent számomra a természet élménye. & 4,51 & 1,782 \\
\hline
\end{tabular}

12. táblázat: A környezeti identitás skála bemutatása

Forrás: saját kutatás

A válaszadók környezeti identitásának az erősségét a skála értéke adja meg. Az EID skála érték átlaga 51,96 (SD=11,86), ami a közepesnél kissé erősebb kötődést jelez a természet felé. A belső konzisztencia vizsgálatára alkalmas Cronbach Alfa értéke 0,863. A demográfiai változókkal összevetve, az indirekt mérés esetében felmerülő nemi különbség nem volt megtalálható a környezeti identitás esetében.

A környezet problémáinak megítélése visszatükröződhet a vásárlói magatartásban is. Ennek vizsgálata során a Roberts-féle (1997) Ecologically Conscious Consumer 
Behaviour skálára (ECCB) támaszkodtam, amely alapján 16 állítást kellett 5 fokú Likert skálán értékelniük a válaszadóknak. A skála értéke ez alapján 16 és 80 között lehet, jelen mintában a skála érték átlaga 45,43 (SD=10,43). A skála Cronbach $\alpha$ értéke 0,854 , szintén megbízhatónak tekinthető.

A mintában lévő férfiak szignifikánsan $(\mathrm{F}(1,194)=9,335, \mathrm{p}=0,003)$ kevesebb környezetbarát cselekvést végeznek, mint a nők $\left(\mathrm{M}_{\text {nö }}=47,30, \mathrm{SD}_{\text {nö }}=9,48 ; \mathrm{M}_{\mathrm{ffi}}=42,78\right.$, $\left.\mathrm{SD}_{\mathrm{ffi}}=11,18\right)$.

\subsection{AZ IMPLICIT ÉS AZ EXPLICIT MÉRÉSEK KAPCSOLATA}

Az elemzés második lépése az explicit és az implicit mérések közötti kapcsolat vizsgálata. A természet és az egyén közötti indirekt kapcsolat (IAT eredményéből származó D-érték) korábbi kutatásokban való mérése során általában gyenge pozitív kapcsolatot mutatott az explicit mérésekkel (Schultz et al., 2004, Schultz - Tabanico, 2007). Jelen kutatás során nem találtam szignifikáns kapcsolatot az implicit és az explicit mérések között (korrelációk eredményei: környezeti attitűddel való kapcsolat: $\mathrm{r}(194)=0,071, \mathrm{p}=0,329$; környezeti identitással való kapcsolat: $\mathrm{r}(194)=0,044, \mathrm{p}=0,542$; környezetbarát vásárlási szokásokkal való kapcsolat: $\mathrm{r}(194)=0,038, \mathrm{p}=0,599)$ ).

A Környezeti identitás explicit mérése esetében ezzel szemben mind a környezeti attitűddel, mind a környezettudatos vásárlási szokásokkal szemben kimutatható a szignifikáns kapcsolat. A környezeti attitüd és a környezeti identitás között közepesen erős pozitív kapcsolat fedezhető fel $(\mathrm{r}(188)=0,466, \mathrm{p}=0,000)$. Hasonlóan erős kapcsolat van a környezettudatos fogyasztói magatartás és a környezeti identitás között is $(\mathrm{r}(194)=0,509, \mathrm{p}=0,000)$.

A környezeti attitüd és a környezettudatos fogyasztói viselkedés között is megfigyelhető a pozitív kapcsolat, ez azonban gyengébb, mint az identitás és a viselkedés között megállapítható korreláció $(\mathrm{r}(190)=0,377, \mathrm{p}=0,000)$.

\subsection{KÖVETKEZTETÉSEK}

A természet és az egyén kapcsolatának indirekt vizsgálata során a természeti környezet és az épített környezet között hasonló preferenciát találtam a kutatás során. A direkt mérések esetében, a környezeti attitüdöt és a környezeti identitást vetettem össze a 
környezetbarát viselkedések végzésével, amely esetekben közepesen erős pozitív kapcsolatot találtam.

Jelen kutatás arra kereste a választ, milyen módszerrel érdemes vizsgálni a környezeti identitást. A kutatás relevanciáját adja, hogy az identitás nem tudatos koncepció, hanem tudattalanul van jelen az egyénben, ami csökkentheti az explicit mérésekkel való vizsgálatok megbízhatóságát. Kutatási tervemben abból az alapfeltevésből indultam ki, hogy az implicit környezeti identitás kapcsolata a környezettudatos fogyasztói viselkedésre erősebb, mint az explicit mérésű identitásnak.

Kutatásunkban a környezeti identitás implicit mérésének eredményei sem az explicit méréssel, sem a kiegészítő környezeti attitüd és környezettudatos cselekvés megjelenésével nem mutat szignifikáns kapcsolatot.

\section{Ez alapján elvetjük kiinduló feltevésünket.}

A Környezeti Identitás skála, mint explicit mérés ugyanakkor pozitív kapcsolatot mutat a környezettudatosság elemeivel. Ennek az eredménynek az egyik magyarázatát az adja, hogy amikor nem tudatosan válaszolunk a környezetvédelemre vonatkozó kérdésekre, a társadalmi elvárásoknak való megfelelés megszünik, és ez a környezettel való gyengébb kapcsolatot eredményezheti. A környezetvédelem témakörei erősen jelen vannak a mindennapjainkban, a médiában, akár a politikában, amely eredményezheti azt, hogy normaként elfogadásra kerültek, így a megfontolt, explicit válaszok esetében a pozitív válaszok erőteljesebben megjelenhetnek.

Az eredmények értelmezésekor érdemes azonban kiemelni, hogy az IAT kutatási módszerben nincs lehetőség a természettel való kapcsolat önálló vizsgálatára, csupán a természeti környezet és az épített környezet közötti preferenciát mutatja meg az eredmény. Az IAT kiinduló feltevése, hogy ha az épített környezethez gyorsabban asszociáljuk az én vonatkozású szavakat, akkor kevésbé érezzük magunkat közel a természethez. Ez alapján felmerül a kérdés, hogy ha énünk fontos részének tekintjük a természetet, az feltétlenül együtt jár-e azzal, hogy az ember által épített környezetet kevésbé értékeljük. A környezeti identitás kialakulását vizsgáló kutatások hangsúlyozzák a természetben eltöltött idő és tapasztalatok fontosságát (Chawla, 1999; Hofmeister-Tóth és tsai., 2012b), azonban a modern urbanizált világban az épített környezet is fontos szerepet játszik az életünkben. Véleményem szerint nem jelenthető ki egyértelműen, hogy a természeti környezet szeretete kizárná az épített 
környezet kedvelését. Az alacsonyabb implicit kötődés mértéke ebből az összehasonlítás okozta torzításból is eredhet. Úgy gondolom emiatt az IAT-Nature eredményeinek értékelése során a hasonló, illetve az alacsony preferenciát mutató egyéneket tekinthetjük természeti kötődéssel rendelkező egyéneknek. Szükségesnek tartom ugyanakkor a különbség értelmezésére további vizsgálatot készíteni, amelyben explicit mérések során is felmérem az épített és a természeti környezet közötti preferencia különbséget.

A bemutatott eredmények értékeléséhez a kutatás korlátainak a figyelembe vétele is szükséges. A megbízhatósági vizsgálatok (split-file reliability) alapján az IAT eredmények belső megbízhatósága alacsony. Ezt okozhatja az önkényes mintavétel, amely során a minta nem került szürésre a válaszadók IAT módszerrel való ismerőssége alapján, illetve a használt szoftverben eltérő az implicit asszociációs teszt felépítési rendje. Az IAT vizsgálatok során javasolt a páros tesztek kétszeri megismétlése, illetve a blokkok random bemutatása; ezekre a szoftverben nem volt lehetőség.

Az IAT-Nature által mért környezeti identitás és a környezetbarát tevékenységek közötti kapcsolat hiányának értékelése során érdemes a kutatás azon jellemzőjét is figyelembe venni, hogy a kimeneti, viselkedéses változó mérése szintén explicit módon történt egy 16 állításból álló skála segítségével. Egy jövőbeli kutatás során érdekes eredményeket hozhat a kimeneti változó implicit mérése, amelyre a kísérlet módszertana nyújt lehetőséget. 


\section{A KÖRNYEZETI IDENTITÁS ÉS A KÖRNYEZETTUDATOS VISELKEDÉS KAPCSOLATÁNAK VIZSGÁLATA}

\subsection{A KUTATÁS CÉLJA ÉS KÖRÜLMÉNYEI}

A kutatás a TÁMOP-4.2.1/B-09/1/KMR-2010-0005 projekt támogatásával készülő Fenntartható fejlődés, élhető régió, élhető települési táj pályázati projektjének keretében készült. A projekt célja a fenntartható fogyasztás alakulásának a vizsgálata volt Magyarországon. A kutatás fókuszában a hazai környezettudatos fogyasztói szokások megjelenése állt. A környezetbarát viselkedés meghatározói között az ismeretet, a tájékozottságot és a főbb pszichográfiai tényezőket vizsgáltuk és kiemelt kérdésként kezeltük a tényezők valós viselkedésre gyakorolt hatásának a vizsgálatát.

Az adatfelvétel 2012 áprilisában zajlott. A kérdőív online (CAWI) megkérdezéssel készült. A minta elemszáma 954 fő, a minta reprezentatív a 18-69 éves hazai rendszeres internet használókra ${ }^{21}$ nem, kor, végzettség, településtípus és régió jellemzők mentén. A kapott adatok elemzését IBM SPSS Statistics 21 és IBM SPSS Amos szoftverekkel végeztük.

A kérdőív 29 kérdésből állt, ebből 11 kérdés vonatkozott a demográfiai adatokra. A megkérdezés megközelítőleg 25 percet vett igénybe. A kérdések a társadalmi értékrendre, a társadalmi normákra, a környezet iráni aggodalomra, az informáltságra, a környezetvédő magatartásokra és a környezeti attitüdre vonatkoztak elsősorban. A kérdőív felépítése a következő volt (végleges kérdőívet lásd a mellékletben):

1. Értékek, normák

A blokk célja a válaszadók értékeinek, és személyes normáinak, illetve azok prioritásának megismerése volt.

2. Informáltság és valós viselkedés

A környezet iránti érdeklődés, információszerzés forrásai és a forrásokban való bizalom kérdései állnak a kérdések középpontjában, valamit a környezetvédő valós viselkedés mértékének a vizsgálata.

${ }^{21} 2012$ decemberében a hazai internetpenetráció 63\% volt a 15-69 éves korosztályban. (Kurucz, 2012) 
3. Környezeti attitűdök vizsgálata

A környezeti attitüd megismerése mellett kitértünk az környezeti aggodalom, a környezetvédő viselkedés motivációinak és az áldozathozatali hajlandóságnak a vizsgálatára is. Célunk az volt, hogy összefüggéseket tárjunk fel az egyes változók között.

4. Önkéntesség

A kérdésblokk az önkéntesség gyakoriságát és a fő területeit vizsgálta.

5. Demográfia

Az általános demográfiai kérdéseken túl (nem, kor, lakhely, iskolai végzettség, jövedelem), kiemelt hangsúlyt kapott a háztartás összetételének vizsgálata, benne a gyermekkel/ kiskorú gyermekkel való együttélés megismerése.

\subsection{MinTA BEMUTATÁSA}

A kutatás mintája reprezentatív a hazai rendszeres internetezőkre nem, kor, végzettség, településtípus és régió jellemzők mentén. Az adatfelvételt az NRC piackutató cég végezte online paneljén. A minta kiválasztásában szürőfeltételt nem alkalmaztunk. Az 1000 fős kiinduló adatbázison adattisztítást végeztünk, amely eredményeként 954 fő maradt a mintában. A mintát a demográfiai jellemzők alapján a 13. táblázat mutatja be.

\begin{tabular}{|l|l|c|c|}
\hline \multirow{4}{*}{ Nem } & & Minta elemszám & Százalékos megoszlás \\
\hline \multirow{5}{*}{ Kor } & Férfi & 477 & $50,0 \%$ \\
\cline { 2 - 4 } & Nö & 477 & $50,0 \%$ \\
\cline { 2 - 4 } & Összesen & 954 & $100,0 \%$ \\
\cline { 2 - 4 } & $15-29$ éves & 362 & $38,0 \%$ \\
\cline { 2 - 4 } & $30-39$ éves & 256 & $26,8 \%$ \\
\cline { 2 - 4 } & $40-49$ éves & 160 & $16,8 \%$ \\
\cline { 2 - 4 } & $50-69$ éves & 954 & $18,4 \%$ \\
\cline { 2 - 4 } & Összesen & 381 & $100,0 \%$ \\
\hline \multirow{5}{*}{ Végzettség } & Alapfokú & 373 & $39,9 \%$ \\
\cline { 2 - 4 } & Középfokú & 200 & $39,1 \%$ \\
\cline { 2 - 4 } & Felsöfokú & 954 & $21,0 \%$ \\
\cline { 2 - 4 } & Összesen & 203 & $100,0 \%$ \\
\cline { 2 - 4 } & Budapest & 525 & $21,3 \%$ \\
\cline { 2 - 4 } & Város & 226 & $23,0 \%$ \\
\cline { 2 - 4 } & Falu & 954 & $100,0 \%$ \\
\cline { 2 - 4 } & Összesen & & \\
\hline
\end{tabular}




\begin{tabular}{|c|c|c|c|}
\hline \multirow{8}{*}{$\begin{array}{l}\text { Lakóhely } \\
\text { régiója }\end{array}$} & Közép & 243 & $25,5 \%$ \\
\hline & Észak & 197 & $20,6 \%$ \\
\hline & Észak-Alföld & 106 & $11,1 \%$ \\
\hline & Dél-Alföld & 135 & $14,1 \%$ \\
\hline & Dél-Dunántúl & 80 & $8,4 \%$ \\
\hline & Közép-Dunántúl & 91 & $9,5 \%$ \\
\hline & Nyugat-Dunántúl & 103 & $10,8 \%$ \\
\hline & Összesen & 954 & $100,0 \%$ \\
\hline \multirow[t]{6}{*}{ Családi állapot } & Egyedülálló & 224 & $23,5 \%$ \\
\hline & $\begin{array}{l}\text { Párkapcsolatban van, de nem él } \\
\text { együtt }\end{array}$ & 121 & $12,7 \%$ \\
\hline & $\begin{array}{l}\text { Házas vagy élettársi } \\
\text { kapcsolatban él }\end{array}$ & 516 & $54,1 \%$ \\
\hline & Elvált & 75 & $7,9 \%$ \\
\hline & Özvegy & 18 & $1,9 \%$ \\
\hline & Összesen & 954 & $100,0 \%$ \\
\hline \multirow[t]{13}{*}{ Jövedelem } & $80.000 \mathrm{Ft}$ alatt & 113 & $11,8 \%$ \\
\hline & $80.000 \mathrm{Ft}-100.000 \mathrm{Ft}$ & 107 & $11,2 \%$ \\
\hline & $100.001 \mathrm{Ft}-150.000 \mathrm{Ft}$ & 170 & $17,8 \%$ \\
\hline & $150.001 \mathrm{Ft}-200.000 \mathrm{Ft}$ & 156 & $16,3 \%$ \\
\hline & $200.001 \mathrm{Ft}-250.000 \mathrm{Ft}$ & 88 & $9,2 \%$ \\
\hline & $250.001 \mathrm{Ft}-300.000 \mathrm{Ft}$ & 52 & $5,4 \%$ \\
\hline & $300.001 \mathrm{Ft}-350.000 \mathrm{Ft}$ & 19 & $2,0 \%$ \\
\hline & $350.001 \mathrm{Ft}-400.000 \mathrm{Ft}$ & 22 & $2,3 \%$ \\
\hline & $400.001 \mathrm{Ft}-450.000 \mathrm{Ft}$ & 6 & $0,6 \%$ \\
\hline & $450.001 \mathrm{Ft}-500.000 \mathrm{Ft}$ & 2 & $0,2 \%$ \\
\hline & $500.000 \mathrm{Ft}$ felett & 6 & $0,7 \%$ \\
\hline & Nem tudom/ nem válaszolok & 213 & $22,3 \%$ \\
\hline & Összesen & 954 & $100,0 \%$ \\
\hline
\end{tabular}

13. táblázat: Minta demográfiai jellemzése

Forrás: saját szerkesztés

\subsection{KÖRNYEZETI IDENTITÁS SKÁLA MEGBÍZHATÓSÁGA}

Az elemzés első lépéseként a Clayton-féle környezeti identitás skála leíró elemzéseit és a megbízhatósági, érvényességi vizsgálatát végeztem el.

A válaszadók között a legnagyobb egyetértés a természet gyermeknevelésben játszott szerepe kapcsán figyelhető meg $(M=6,34)$. Legkevésbé a környezetben eltöltött idő mennyiségével $(M=4,65)$ és a más élőlényekkel való közös vonással értettek egyet $(\mathrm{M}=4,64)$. A skála állítások átlagait a 14. táblázat részletezi. A skála megbízhatósága 
szempontjából hangsúlyos, hogy az adott skála hasonló eredményeket adjon abban az esetben is, ha eltérő mintán kerül megismétlésre (Ketskeméty és tsai., 2011). Jelen kutatás eredményei összhangban vannak az előtanulmányokban bemutatott hallgatói megkérdezés eredményeivel.

\begin{tabular}{|l|c|c|c|}
\hline EID skála & $\mathbf{N}$ & $\mathbf{M}$ & SD \\
\hline $\begin{array}{l}\text { Minden gyermek nevelésének fontos része kellene, hogy legyen a természet } \\
\text { világának megismerése. }\end{array}$ & 951 & 6,34 & 1,175 \\
\hline $\begin{array}{l}\text { Inkább élnék egy szép kilátással rendelkező kisebb szobában vagy házban, } \\
\text { mint egy olyan szobában, vagy házban, amely nagyobb, de már épületekre } \\
\text { néz. }\end{array}$ & 952 & 5,98 & 1,522 \\
\hline $\begin{array}{l}\text { Úgy érezném, életem fontos része hiányzik, ha nem tudnék időröl-időre } \\
\text { kimenni a szabadba és élvezni a természetet. }\end{array}$ & 951 & 5,93 & 1,450 \\
\hline $\begin{array}{l}\text { Még nem láttam olyan müvészeti alkotást, amely annyira gyönyörü lenne, } \\
\text { mint a természet olyan csodái, mint a naplemente vagy egy hegylánc. }\end{array}$ & 952 & 5,78 & 1,538 \\
\hline $\begin{array}{l}\text { Ha kiborultam, vagy csak stresszes vagyok, jobban érzem magam, ha kis időt } \\
\text { a szabadban tölthetek élvezve a természetet. }\end{array}$ & 953 & 5,70 & 1,533 \\
\hline Úgy tekintek magamra, mint aki a természet része, nem független töle. & 950 & 5,46 & 1,570 \\
\hline $\begin{array}{l}\text { A Földdel szembeni felelösségteljes viselkedés, azaz a fenntartható életmód } \\
\text { követése része az erkölcsi kódexemnek. }\end{array}$ & 951 & 5,21 & 1,542 \\
\hline $\begin{array}{l}\text { Ha lenne elég időm vagy pénzem, egy részét biztosan arra szánnám, hogy } \\
\text { környezetvédelmi ügyekkel foglalkozzam. }\end{array}$ & 953 & 5,19 & 1,725 \\
\hline Úgy érzem, spirituális feltöltődést jelent számomra a természet élménye. & 949 & 5,04 & 1,842 \\
\hline $\begin{array}{l}\text { Sok időt töltök természeti környezetben (erdő, hegyvidék, puszta, tópart, } \\
\text { tengerpart). }\end{array}$ & 951 & 4,65 & 1,774 \\
\hline Érzem, sok közös vonásom van más élölényekkel. & 951 & 4,64 & 1,815 \\
\hline
\end{tabular}

14. táblázat: Az EID skála leíró statisztikái

Forrás: saját szerkesztés

A skála érték átlaga 59,91 ( $\mathrm{SD}=12,604)$, amely a hallgatói minta 51,76 közepesen erős átlagától magasabb értéket jelent. Az adatbázisban a skálaérték minimuma 11, míg maximuma 77 volt. A válaszadók kérdőívre adott válaszainak tartalmi ellenőrzése után a szélsőértéket adó válaszadók elemzésben való benntartása mellett döntöttem.

A skála megbízhatóságának vizsgálatára a Cronbach-alfa mutatót és a tétel-skála korrelációkat vizsgáltam. A Cronbach-alfa a belső konzisztencia vizsgálatára általánosan alkalmazott mutatószám (Cronbach, 1951; Cronbach és Meehl, 1968).

A megbízhatósági adatokat a következő értékek mellett elemezzük:

- Tétel-skála korreláció értéke legyen 0,30 felett (Norusis, 1993)

- Cronbach $\alpha$ értéke legyen 0,7 felett (Nunnally, 1967).

A Cronbach-alfa értéke $\alpha=0,905$, amely megfelelő megbízhatóságot mutat, valamint nincs olyan skálatétel, amelynek az elhagyásával az Alfa értéke növelhető lenne. A korrigált tétel-skála korreláció az állítás pontszámai és az összes többi változóra kapott 
pontszámok összegeként számított „korrigált” teljes skála-pontszámok közötti korrelációs együtthatókat tartalmazza (Ketskeméty és tsai., 2011). Ezen a mutatón alacsony értéket elérő állítás vélhetően valami mást mér, mint a többi, ezért érdemes kiszürni. Az EID skála esetében ezek az értékek minden esetben meghaladják a 0,5-ös értéket.

\begin{tabular}{|c|c|c|c|c|}
\hline & EID skála állításai & $\begin{array}{l}\text { Átlag, a } \\
\text { tétel } \\
\text { törlése } \\
\text { esetén }\end{array}$ & $\begin{array}{l}\text { Korrigált } \\
\text { tétel - skála } \\
\text { korreláció }\end{array}$ & $\begin{array}{l}\alpha, \text { a tétel } \\
\text { törlése } \\
\text { esetén }\end{array}$ \\
\hline EID1 & $\begin{array}{l}\text { Sok időt töltök természeti környezetben (erdő, } \\
\text { hegyvidék, puszta, tópart, tengerpart). }\end{array}$ & 55,29 &, 560 & 901 \\
\hline EID2 & $\begin{array}{l}\text { Úgy tekintek magamra, mint aki a természet } \\
\text { része, nem független tőle. }\end{array}$ & 54,45 & ,717 & ,892 \\
\hline EID3 & $\begin{array}{l}\text { Ha lenne elég időm vagy pénzem, egy részét } \\
\text { biztosan arra szánnám, hogy } \\
\text { környezetvédelmi ügyekkel foglalkozzam. }\end{array}$ & 54,72 & 651 & 896 \\
\hline EID4 & $\begin{array}{l}\text { Ha kiborultam, vagy csak stresszes vagyok, } \\
\text { segít jobban érezni magam, ha kis időt a } \\
\text { szabadban tölthetek élvezve a természetet. }\end{array}$ & 54,22 &, 718 & ,892 \\
\hline EID5 & $\begin{array}{l}\text { Érzem, hogy sok közös vonás van bennem és } \\
\text { más élölényekben. }\end{array}$ & 55,27 & ,673 & ,895 \\
\hline EID6 & $\begin{array}{l}\text { A Földdel szembeni felelősségteljes } \\
\text { viselkedés, azaz a fenntartható életmód } \\
\text { követése része az erkölcsi kódexemnek. }\end{array}$ & 54,71 & ,734 & ,891 \\
\hline EID7 & $\begin{array}{l}\text { Minden gyermek nevelésének fontos része } \\
\text { kellene, hogy legyen a természet világának } \\
\text { megismerése. }\end{array}$ & 53,56 & ,628 & ,898 \\
\hline EID8 & $\begin{array}{l}\text { Inkább élnék egy szép kilátással rendelkezö } \\
\text { kisebb szobában vagy házban, mint egy olyan } \\
\text { szobában, vagy házban, amely nagyobb, de } \\
\text { más épületekre néz. }\end{array}$ & 53,93 &, 544 & ,901 \\
\hline EID9 & $\begin{array}{l}\text { Úgy érezném, hogy az életem egy fontos } \\
\text { része hiányozna, ha nem tudnék időről-időre } \\
\text { kimenni a szabadba és élvezni a természetet. }\end{array}$ & 53,98 & 697 & 894 \\
\hline EID10 & $\begin{array}{l}\text { Még nem láttam olyan müvészeti alkotást, } \\
\text { amely annyira gyönyörü lenne, mint a } \\
\text { természet olyan csodái, mint a naplemente } \\
\text { vagy egy hegylánc. }\end{array}$ & 54,14 &, 591 & 899 \\
\hline EID11 & $\begin{array}{l}\text { Úgy érzem, spirituális feltöltődést jelent } \\
\text { számomra a természet élménye. }\end{array}$ & 54,86 & ,643 & ,897 \\
\hline
\end{tabular}

15. táblázat: Az EID skála belső konzisztenciája

Forrás: saját szerkesztés

A Split-half model („kettévágott skála modell”) szintén a megbízhatóság ellenőrzésére alkalmas módszertan. A skálát az első 6 és az utolsó 5 állításra bontottam szét. A két fél skála Cronbach-alfa értékei (rendre $\alpha_{1}=0,859$ és $\alpha_{2}=0,785$ ) gyengültek, de továbbra 
is megfelelő értéket mutatnak. A két fél skála tételei közötti korrelációs együttható 0,809 .

A skála elméleti koncepciójának alkalmasságát az előtanulmányok során két hallgatói mintán is teszteltem és a feltáró faktorelemzések visszatükrözték a várt egy dimenziós elméleti konstrukciót. A skála fejlesztés, tesztelés következő fázisának tekinthető, amikor az elméleti konstrukció megalapozottá vált, a skála koncepció konfirmatív faktorelemzéssel (Confirmatory factor analysis, CFA) történő tesztelése (Brown, 2006). Bár a feltáró és a megerősítő faktorelemzés használatáról folyamatos vita látható az eltérő iskolát képviselő kutatók között, vannak olyan alapvető kérdések, amelyben közös állásponton figyelhető meg (Hurley és tsai., 1997):

- a CFA alkalmazásához a priori elmélet szükséges. Nem szabad feltáró módszerként tévesen alkalmazni a konfirmatív faktorelemzést.

- amennyiben a modell nem müködik az elvárt elméletnek megfelelően, a módosított, újraspecifikált modell igazolásához új mintára van szükség.

A korábbi kutatásokra alapozva a jelenlegi adatbázison az IBM AMOS 21-es szoftvercsomaggal elvégeztük az EID skála konfirmatorikus faktor elemzését ${ }^{22}$. A megbízhatóság vizsgálatára a Cronbach-alfa mellett - annak kritikái miatt is (Malhotra és Simon, 2009) - vizsgáltuk a composit reliability (CR) mutatószámot, amely az indikátor szintjén mutatja a megbízhatóságot (Raykov, 1998; Raykov és Grayson, 2003). A CR mutató a látens változóhoz kapcsolódó indikátorok sztenderdizált faktorsúlyainak és a mérési hibának a számított értéke. Az értéke 0,7 fölött számít elfogadhatónak (Hair és tsai., 2010), de vannak szigorúbb (0,8 fölött) és megengedőbb (0,6 fölött) nézetek is (Byrne, 2010).

Az indikátorok megbízhatóságának vizsgálatakor az elvárás az, hogy a látens változó és az indikátorai között a korreláció legalább 0,7 legyen, ami azt jelenti, hogy a változó faktorsúlya el kell, hogy érje a 0,7-et (Henseler és tsai., 2009). A szakirodalom az indikátor eltávolítását azonban akkor javasolja, ha 0,4 alatti a faktorsúly és az eltávolításával a CR mutató javul.

\footnotetext{
${ }^{22}$ Normalitás vizsgálat mellett, elfogadtam azt az előfeltevést, hogy az adott 923 fös minta megfelelően nagy ahhoz, hogy feltételezhetjük az adatok normális eloszlását. A hiányzó adatot tartalmazó válaszadókat az elemzésből eltávolítottam.
} 
A faktorelemzés különbözőségi érvényességének vizsgálatára az átlagos magyarázott variancia (Average variance extracted, AVE) mutatót használtam, aminek az értéke 0,5 fölött fogadható el (Fornell és Larcker, 1981).

A konfirmatív faktor elemzés a környezeti identitás látens változóhoz a környezeti identitás skála 11 skálatételét tartalmazza, mint indikátor (CFA ábrát lásd a mellékletben). A CR megbízhatósági mutató teljesíti az elvárt 0,7 feletti értéket, míg az AVE mutató enyhén elmarad az elvárt 0,5-ös értéktől. A megbízhatósági és érvényességi eredményeket a 16. táblázat mutatja be. A faktorsúlyok alapján a megerősítő faktorelemzésből is látható, hogy a 8 . állítás rendelkezik a legalacsonyabb korrelációval a látens változóval, amely egybecseng a korábbi feltáró faktorelemzések jelzéseivel is.

\begin{tabular}{|l|c|c|c|c|}
\hline Változó & Faktorsúly & CR & AVE & Cronbach- alfa \\
\hline Környezeti identitás & & 0,91 & 0,47 & 0,90 \\
\hline EID_1 & 0,610 & & & \\
\hline EID_2 & 0,767 & & & \\
\hline EID_3 & 0,679 & & & \\
\hline EID_4 & 0,761 & & & \\
\hline EID_5 & 0,698 & & & \\
\hline EID_6 & 0,766 & & & \\
\hline EID_7 & 0,648 & & & \\
\hline EID_8 & 0,539 & & & \\
\hline EID_9 & 0,746 & & & \\
\hline EID_10 & 0,605 & & & \\
\hline EID_11 & 0,693 & & & \\
\hline A
\end{tabular}

16. táblázat: A megerősítő faktor elemzés eredményei, a skála megbízhatósági és érvényességi mutatókkal

Forrás: saját elemzés

A CFA modell illeszkedésének vizsgálatára számos mutatót javasol a szakirodalom (részletesebben lásd: (Brown, 2006; Hair és tsai., 2010; Henseler és tsai., 2009). A nagy minta elemszámhoz illeszkedően az alábbi mutatószámokat vizsgáltuk az illeszkedés meghatározásához: CMIN: 336,33 (df=44; $\mathrm{p}<0.000)$; $\mathrm{CMIN} / \mathrm{df}=7,644$; $\mathrm{GFI}=0,930 ; \mathrm{TLI}=0,922 ; \mathrm{CFI}=0,937$; RMSEA $=0,085$. A GFI, TLI és CFI index esetében a 0,9 fölötti értékek elfogadható illeszkedést mutatnak (Brown, 2006), míg az RMSEA ajánlások a 0,05 alatti értéket fogadják el kiváló illeszkedésnek. Homburg és Klarmann ajánlása alapján a CFA esetében az RMSEA mutató túl szigorú, ezért a 0,1 alatti érték is elfogadható illeszkedést jelent (Homburg és Klarmann, 2006). 
A megbízhatósági és érvényességi vizsgálatok alapján a skála tételei között a kapcsolat megfelelönek mondható, valamint a konfirmatív faktorelemzés eredményei alapján is egy dimenziósnak tekinthető. Ez megegyezik a szakirodalomban foglaltakkal a skála felépítéséről (Clayton, 2003). A vizsgálatok alapján a további elemzésekhez a teljes skálát, az összes skálatételből kialakított az indikátorok lineáris kombinációjával létrehozott skálaértéket alkalmazom.

Érdemes azonban kiemelni, hogy az előtanulmányokhoz hasonlóan a skála 1, 8 és 10es tételei, amelyek a természetben való viselkedés és a természet esztétikai értékét jelenítik meg, enyhén kilógnak a többi állítás közül, ezeknek az eredményeknek a további felhasználására a következtetések során teszek további javaslatot.

\subsection{A KÖRNYEZETI IDENTITÁS SKÁLA DEMOGRÁFIAI MEGHATÁROZÓ TÉNYEZÖI}

A demográfiai változók környezeti identitásra vonatkozó hatásaira a 2. hipotéziscsoport vonatkozik. A kapcsolatok vizsgálatára a skálák mérési szintje miatt varianciaelemzést végeztem. A vizsgálatba bevontam a nem, a kor, családi állapot, a háztartásban lévő gyermekek száma, a végzettség, a jövedelem, a lakóhely, és a gyermekkori lakóhely változókat. A demográfiai változók közül a várakozásomtól eltérően a nem, a kor és a családi állapot bizonyult szignifikáns hatással lévő változónak.

A nők szignifikánsan erősebb környezeti identitással rendelkeznek, mint a férfiak $[\mathrm{F}(1,920)=32,888, \mathrm{p}=0,000]$, amely alapján a H2b hipotézis igazolt. Ez az eredmény alapvetően összhangban van a környezetbarát fogyasztó vizsgálata során megjelenő általános képpel, miszerint a nők gyakrabban végeznek környezetbarát tevékenységeket (Straughan és Roberts, 1999), pozitívabb attitűddel rendelkeznek és jobban aggódnak a környezetért, mint a férfiak (Diamantopoulos és tsai., 2003). A nők erősebb elköteleződését a természet irányába a leggyakrabban a nemi szerepekkel és a szocializációval magyarázzák (Zelezny és tsai., 2000). A szocializációs elmélet felteszi, hogy az egyének viselkedése az alapján formálódik, hogy milyen elvárásokat támasztanak az nemével szemben az adott kulturális környezetben. A nök a legtöbb kultúrában gondoskodónak, együtt érzőnek, kooperatívnak, segítőkésznek és mástól 
függőnek szocializálódnak, míg a férfiaknak függetlennek és versengőnek kell lenni (Eagly, 1987, idézi: Zelezny és tsai, 2000). Ezek a különbségek lehetnek hatással az eltérő környezeti attitüd kialakulására és véleményem szerint az erősebb környezeti identitásra is.

A kor esetében a környezettudatossághoz kötődő nemzetközi eredmények általában vagy nem mutatnak ki kapcsolatot, vagy negatív kapcsolatot mutatnak (Diamantopoulos és tsai., 2003; Roberts, 1996), azaz a fiatalabb korosztály pozitívabb környezeti attitüddel és magasabb viselkedési szándékkal rendelkezik, azonban a valós viselkedésben általában az idősebb korosztály az aktívabb. Dunlap és Van Liere (1980) szerint a negatív irányú kapcsolat azzal indokolható, hogy a környezettudatos viselkedés a fennálló társadalmi rend megváltoztatását igényli, a szokások átalakítását, és a szükséges reformokat pedig inkább a fiatalok támogatják.

A környezeti identitás esetében jelen kutatásban pozitív irányú kapcsolatot találtunk a korral. Ez az eredmény azonban egybecseng a korábbi hazai kutatásokkal, amelyek a fiatal lakosságot kevésbé környezettudatosnak találták (Hofmeister-Tóth és tsai., 2012b). Az egy szempontos varianciaelemzés szignifikáns különbséget mutat a különböző korcsoportok között $(\mathrm{F}(3,918)=5,551, \mathrm{p}=0,001)$. A Tukey HSD post-hoc teszt alapján szignifikáns különbség van az idösebb válaszadók (50-69 év között) és a 15-29, illetve 30-39 év közötti válaszadók között (az átlagoknak és szórásoknak a részletes bemutatását a 17. táblázat tartalmazza). Nincs azonban szignifikáns különbség a 40-49 éves válaszadók esetében. Az eredmények alapján a H2d hipotézist elutasítom, a környezeti identitás és a kor között pozitív kapcsolatot találtam.

Két utas, hierarchikus ANOVA vizsgálatok segítségével vizsgáltam a demográfiai változók közötti interakciókat is. A nem és a kor együttes vizsgálata során szignifikáns föhatásokat találtam (nem: $F(1,915)=33,671 ; p=0,000$; kor: $F(3,915)=7,518 ; p=0,000)$, azonban a köztük lévő interakció nem szignifikáns, a két változónak önálló hatása van. Azonban érdemes kiemelni, hogy a parciális hatások esetében mind a nem ( Beta $^{2}=4 \%$ ) mind a kor $\left(\operatorname{Beta}^{2}=2,3 \%\right)$ hatása erősödik. Abban az esetben tehát, ha a kor hatását kontroll alatt tartjuk, a nemek közti különbség még erősebbé válik és fordítva (a kétutas ANOVA részletes táblázatait lásd a Mellékletben). A modell 5,8\%-ot magyaráz a környezeti identitás alakulásából $\left(\mathrm{R}^{2}=0,0576\right)$.

A kor és a családi állapot esetében ellentétes interferencia figyelhető meg. Amennyiben a hierarchikus ANOVA-ba a kor változó kerül be elsőnek, szignifikáns 
főhatás figyelhető meg $(\mathrm{F}(3,905)=5,642, \mathrm{p}=0,001)$. A családi állapot föhatása is szignifikáns $(\mathrm{F}(4,905)=5,058, \mathrm{p}=0,000)$, azonban interakció ebben a modellben sincs. A parciális hatások rendre csökkennek a másik független változó kontrol alatt tartásával. A modell által magyarázott hányad 3,9\% $\left(\mathrm{R}^{2}=0,039\right)$.

\begin{tabular}{|c|c|c|c|}
\hline Változó & Elemszám & Átlag & Szórás \\
\hline \multicolumn{4}{|c|}{ NEM } \\
\hline Nö & 453 & 62,30 & 11,768 \\
\hline Férfi & 469 & 57,61 & 12,965 \\
\hline Összesen & 923 & 59,91 & 12,604 \\
\hline \multicolumn{4}{|c|}{ KOR } \\
\hline $15-29$ & 350 & 58,46 & 13,690 \\
\hline $30-39$ & 249 & 59,31 & 12,321 \\
\hline $40-49$ & 156 & 60,77 & 10,820 \\
\hline $50-69$ & 167 & 63,07 & 11,643 \\
\hline Összesen & 923 & 59,91 & 12,604 \\
\hline \multicolumn{4}{|c|}{ CSALÁDI ÁLLAPOT } \\
\hline Egyedülálló & 219 & 55,92 & 14,069 \\
\hline Párkapcsolatban van, de nem él együtt & 118 & 60,23 & 13,851 \\
\hline Házas vagy élettársi kapcsolatban él & 498 & 61,17 & 11,126 \\
\hline Elvált & 72 & 62,12 & 13,286 \\
\hline Özvegy & 16 & 63,18 & 11,649 \\
\hline Összesen & 923 & 59,91 & 12,604 \\
\hline \multicolumn{4}{|c|}{ HÁZTARTÁS MÉRETE } \\
\hline 1 fö & 98 & 57,41 & 14,814 \\
\hline 2 fö & 259 & 62,48 & 11,331 \\
\hline 3 fö & 231 & 59,25 & 13,561 \\
\hline 4 fö & 214 & 59,33 & 12,028 \\
\hline 5 fö vagy több & 121 & 58,77 & 11,660 \\
\hline Összesen & 923 & 59,91 & 12,604 \\
\hline
\end{tabular}

17. táblázat: Demográfiai különbségek a környezeti identitás értékeiben Forrás: saját elemzés

A vizsgált demográfiai változók közül a családi állapot szignifikáns hatása is kimutatható a környezeti identitásra. A szakirodalom a családi állapot vizsgálata során általában a házasság jelentőségét igyekezett feltárni. Abban az esetben, amikor szignifikáns eredményeket találtak, a házasok magasabb környezeti aggodalomról és több környezetbarát cselekvésről számoltak be (Diamantopoulos és tsai., 2003). A házasság pozitív hatását azzal indokolják, hogy ilyenkor az egyének aktívabban vesznek részt a közösségben, jobban meghatározza az életüket a társas hálózatuk (Dupont, 2004; Torgler és García-Valiñas, 2007). Emellett a helyi környezet problémái azért is jobban érintheti őket, mert saját házzal rendelkeznek, illetve megjelenhet a „szülői hatás”, amely a gyermekeik jövőjéért való aggodalmat növeli. 
Az egy szempontos varianciaelemzés szignifikáns különbséget mutat a különböző családi állapotok között $(\mathrm{F}(4,917)=7,782, \mathrm{p}=0,000)$. A Tukey HSD post-hoc teszt alapján a szignifikáns különbség az egyedülállók csoportja és a többi családi állapot között jelenik meg. Az egyedülállók 55,92-es környezeti identitás átlaga jóval elmarad a többi csoportétól (az átlagoknak és szórásoknak a részletes bemutatását a 17. táblázat tartalmazza $\left.{ }^{23}\right)$.

Jelen kutatás eredményei szintén a párkapcsolat fontosságára hívják fel a figyelmet. Ez azonban nem jár együtt a gyermekek számával, így a jelenség magyarázatát nem a gyermekek iránti felelősségérzetre, hanem az általánosabb másért való felelősség vállalásra lehet visszavezetni, amely utat nyithat a tágabb környezet iránti felelősségvállalásnak, azaz a környezet iránti elköteleződésnek is.

Ezt a következtetést támogatja az is, hogy a háztartás méretének is szignifikáns hatása van a környezeti identitás erősségére $(F(4,917)=4,226, p=0,002)$. A Tukey HSD posthoc teszt eredménye alapján a szignifikáns különbséget a 2 fős háztartások átlagon felüli erősségű környezeti identitása indokolja $(\mathrm{M}=62,48 ; \mathrm{SD}=11,331)$. Ez a magas érték azonban nem marad meg a nagyobb létszámú családok esetében, amely alapján arra következtethetünk, hogy a párkapcsolat, illetve a házasság kialakítása lehet egy olyan pont az ember életében, amely változást hozhat.

A nem és a családi állapot két utas ANOVA-val történő vizsgálata során szignifikáns fó és interakciós hatásokat találtam. A nem főhatása $F(1,913)=34,083, p=0,000$, a családi állapot föhatása $F(4,913)=6,081, p=0,000$. A nem és a családi állapot között lévő interakció $F(4,913)=4,087, p=0,003$. Ahogy a 14. ábrából látható, nem ordinális interakcióról beszélhetünk, amely során a házasok, illetve élettársi kapcsolatban élők esetében megszünik a nemek közötti szignifikáns különbség. Emellett eltérő tendencia figyelhető meg az elvált illetve az özvegy válaszadók esetében nemek szerint, míg a nők környezeti identitása ilyenkor a legerősebb, a férfiak esetében a házasságban élőkhöz képest gyengébb környezeti identitással rendelkeznek.

${ }^{23}$ Az özvegyek csoportja esetében a kis minta elemszám miatt a szignifikáns különbség nem mutatható ki. 


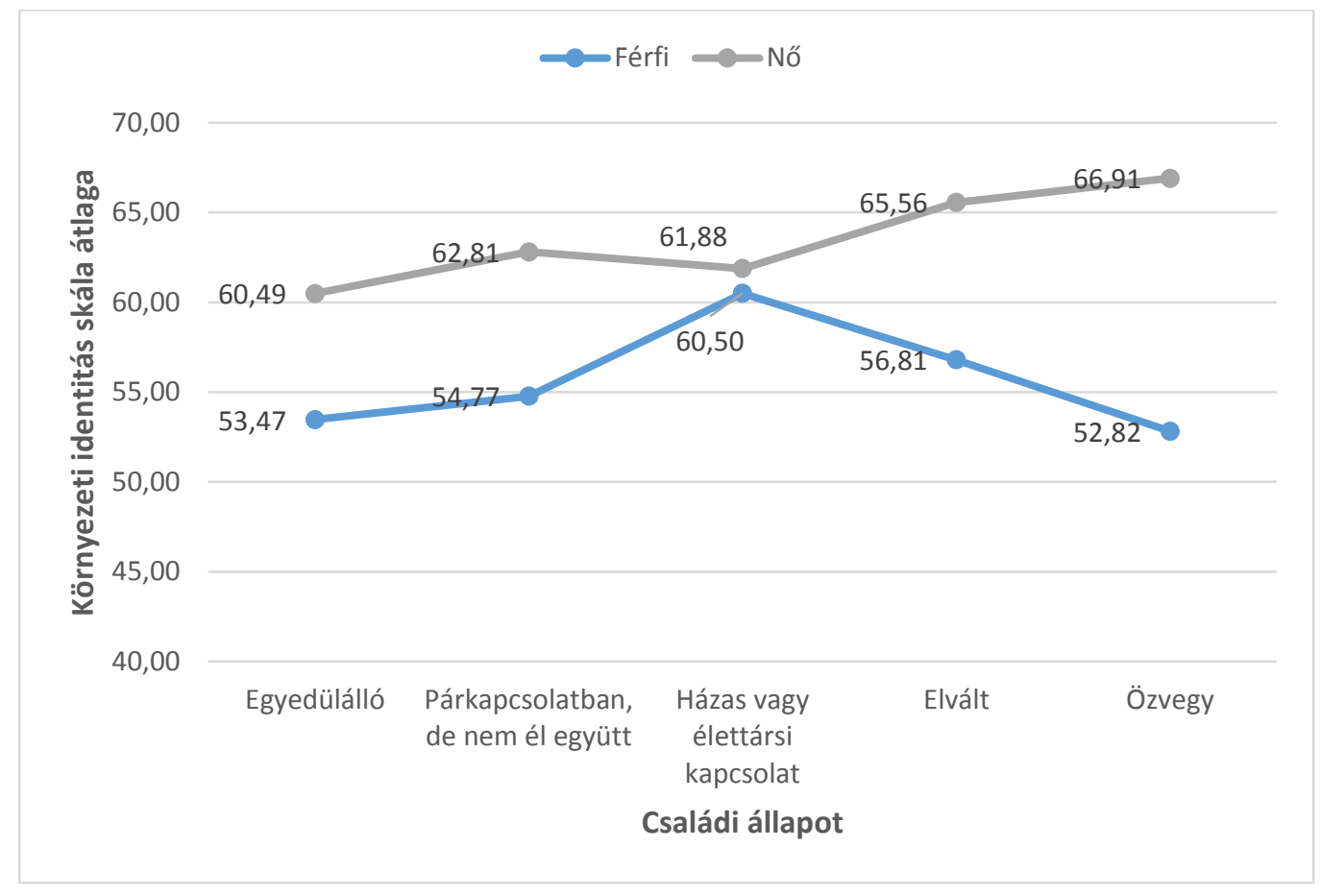

14. ábra: Interakció a Nem és a Családi állapot változók között

Forrás: saját elemzés

A kor és a családi állapot hatásának együttes vizsgálata során nem találtunk szignifikáns interakciót $(\mathrm{F}(10,905)=0,804, \mathrm{p}=0,625)$. A Beta mutatók (lásd melléklet) vizsgálatával azonban látható, hogy a két faktor között interferencia van, ha az egyiket kontrol alatt tartjuk, a másiknak csökken a magyarázó ereje. Ez érthető, hiszen a kor előrehaladtával csökken az egyedülállók száma, így a családi állapot is megjelenik a kor környezeti identitásra gyakorolt pozitív hatásában és ez fordítva is igaz.

A gyermekek számát általában pozitív hatású tényezőnek tekintik a környezeti attitűd, illetve a környezeti aggodalom szempontjából. Ennek ellenére nem minden kutatás talál szignifikáns kapcsolatot a változók között (Diamantopoulos és tsai., 2003). Jelen kutatásban sem találtam különbséget a környezeti identitás tekintetében azok között a háztartások között, ahol van, illetve ahol nincs gyermek. A családi állapot további vizsgálata azonban feltárta, hogy ha a családi állapotot és a gyermek meglétét két utas AVONA-val vizsgáljuk, szignifikáns interakciót találunk $(\mathrm{F}(4,913)=2,581, \mathrm{p}=0,036)$. A családi állapot esetében van szignifikáns föhatás is $(F(4,913)=8,113, p=0,000)$, a gyermek megléte esetében azonban nincs főhatás $(F(1,913)=1,136, p=0,287)$. A két változó között nem ordinális, egymást keresztező interakció figyelhető meg (15. ábra). Míg az egyedülállók, a párkapcsolatban élők és házasok esetében nincs jelentős eltérés abban az esetben, amikor van, illetve amikor nincs gyermek a háztartásban, az elvált 
illetve az özvegy válaszadók esetében a gyermekkel együtt élők erősebb környezeti identitással rendelkeznek.

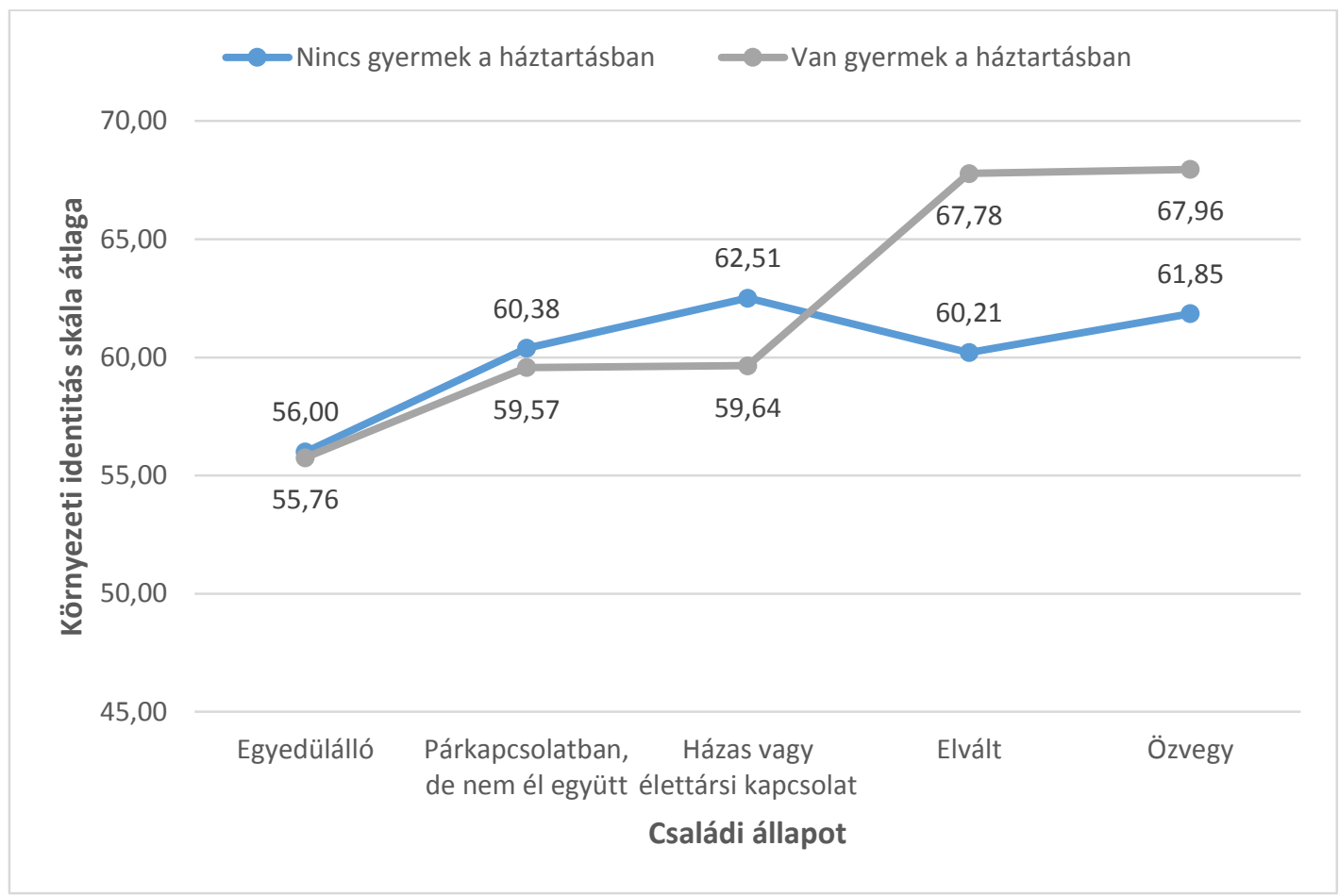

15. ábra: Interakció a Családi állapot és Gyermek léte változók között

Forrás: saját elemzés

Összefoglalóan tehát megállapíthatjuk, hogy a vizsgált demográfiai változók közül szignifikáns hatása a nemnek, a kornak, a háztartás méretének és a családi állapotnak van a környezeti identitásra. A négy változót hierarchikus variancia elemzés során vizsgálva megállapítottam, hogy 7,8\%-ot magyaráznak a környezeti identitás erősségéből $\left(\mathrm{R}^{2}=0,078\right)$. Amennyiben a parciális hatásokat vizsgáljuk, legnagyobb hatással a nem rendelkezik, ezt követi a kor és a családi állapot hatása, majd a háztartás mérete (18. táblázat).

\begin{tabular}{|l|c|c|c|}
\hline & ETA & BETA & BETA $^{2}$ \\
\hline Nem & 0,135 & 0,099 & 0,010 \\
\hline Kor & 0,133 & 0,104 & 0,011 \\
\hline Családi állapot & 0,181 & 0,103 & 0,011 \\
\hline Háztartás mérete & 0,186 & 0,178 & 0,032 \\
\hline
\end{tabular}

18. táblázat: Demográfiai változók hatása a környezeti identitásra, hierarchikus ANOVA Forrás: saját elemzés

\section{A H2a és H2c hipotéziseinket a kapcsolat hiánya miatt elvetettük.}




\subsection{AZ ÉRTÉKEK HATÁSA A KÖRNYEZETI IDENTITÁSRA}

A kutatás során a Kahle-féle LOV értéklistát használtuk (részletes bemutatása 3.4.2 fejezetben). Külső értékek közé tartozik a Valahová tartozás, a Biztonság és az Elismertség. A Biztonság a lakosságnak a legfontosabb érték volt 2012-ben. A hazai kutatások általában hasonló sorrendet tárnak fel (Nagy és tsai., 2012), a Biztonság a legfontosabb, míg az Elismertség és a Szórakozás és élet élvezete értékek az utolsó helyeken szerepelnek.

\begin{tabular}{|l|r|r|}
\hline $\mathrm{N}=799^{24}$ & Átlag & Szórás \\
\hline Biztonság & 8,31 & 1,215 \\
\hline Önbecsülés & 7,97 & 1,432 \\
\hline Jó kapcsolat másokkal & 7,80 & 1,454 \\
\hline Valahová tartozás & 7,56 & 1,709 \\
\hline Önmegvalósítás & 7,41 & 1,586 \\
\hline Elismertség & 6,82 & 1,887 \\
\hline Az alkotás érzése & 6,83 & 1,958 \\
\hline Szórakozás és az élet élvezete & 6,69 & 1,903 \\
\hline
\end{tabular}

19. táblázat: LOV értékek átlagai a teljes mintára vonatkozóan Forrás: saját elemzés

A H3 hipotézis az értékek hatására vonatkozik. Az értékek és a környezeti identitás kapcsolatának a vizsgálatára lineáris regresszió elemzést végeztem.

A regresszió elemzés elvégzéséhez az adatoknak meg kell felelniük a homoszkedaszticitás és a normalitás előfeltételeknek, valamint biztosítani kell a multikollinearitás, és az autokorreláció csekély mértékét. A korrelációs tábla vizsgálatából látható (lásd melléklet), hogy a független változók között nincs erős korreláció, egyedül a Valahová tartozás és a Jó kapcsolat másokkal értékek illetve az Önbecsülés és az Önmegvalósítás értékek között van 0,5 fölötti érték. A multikollinearitást vizsgáló mutatók (Tolerancia $>0,1 ; \mathrm{VIF}<10)$ mind megfelelnek a kritériumoknak (Hair és tsai., 2010), ezért a változók között multikollinearitás nem áll fenn. A reziduálisok függetlenségének az ellenőrzésére alkalmas a Durbin-Watson mutató, amely jelen esetben az autokorreláció elhanyagolhatóan csekély voltát mutatja (Durbin-Watson=1,938) ${ }^{25}$. A homoszkedaszticitás ellenőrzésére alkalmas scatterplot ábra megfelelő tömörülést mutat, valamint a normalitás feltételének ellenőrzésére

\footnotetext{
${ }^{24}$ A regresszió elemzéshez a hiányzó értékeket és a szélső értékeket eltávolítottuk a mintából

${ }^{25}$ Nagyobb mint 500 fős mintaelemszám esetén a Durbin - Watson-mutató értékének 1,8 és 2,2 közé kell esnie (Székelyi és Barna, 2008)
} 
alkalmas hisztogram és ábra is megfelelő alakot és elfogadható illeszkedést mutat (lásd melléklet).

A két lépcsős hierarchikus, többváltozós lineáris regresszió ${ }^{26}$ esetében a függő változó a környezeti identitás volt. Az első lépésben a demográfiai változókat vontam be (ahol szükséges volt dummy változók segítségével), mint a nem, kor. A második lépcsőben vontam be a 8 LOV értéket. A változók modellbe léptetésének sorrendje annak érdekében alakult, hogy a vizsgált demográfiai változók hatása kiszürhető legyen.

\begin{tabular}{|c|c|c|c|c|c|c|c|}
\hline & \multicolumn{3}{|c|}{ Első szakasz } & \multicolumn{3}{|c|}{ Második szakasz } \\
\hline & & B & $\beta^{l}$ & $\mathrm{t}$ & B & $\beta^{l}$ & $\mathrm{t}$ \\
\hline \multirow{2}{*}{ 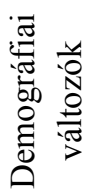 } & Nem & 4,912 & ,216 & $6,300 * *$ & 3,590 &, 158 & $4,728^{* *}$ \\
\hline & Életkor &, 153 &, 175 & $5,099 * *$ & ,098 &, 112 & $3,462 * *$ \\
\hline \multirow{3}{*}{ ح) } & Az alkotás érzése & & & & 1,554 & ,269 & $7,621^{* *}$ \\
\hline & Önbecsülés & & & & 1,063 & ,134 & $3,567^{*}$ \\
\hline & Biztonság & & & &, 741 & ,079 & $2,222^{*}$ \\
\hline & $\mathrm{R}^{2}$ & \multicolumn{3}{|c|}{0,070} & \multicolumn{3}{|c|}{0,209} \\
\hline & Adjusted $\mathrm{R}^{2}$ & \multicolumn{3}{|c|}{0,068} & \multicolumn{3}{|c|}{0,204} \\
\hline & $\mathrm{F}$ & \multicolumn{3}{|c|}{$30,009^{* *}$} & \multicolumn{3}{|c|}{$41,846 * *$} \\
\hline
\end{tabular}

$* \mathrm{p}<0.05 . * * \mathrm{p}<0.001$

20. táblázat: Többváltozós lineáris regresszió eredményei az értékek környezeti identitásra gyakorolt hatásának vizsgálatára

Forrás: saját elemzés

Az első szakaszban a Nem, majd a Kor változó került bevonásra, így a demográfiai változók bevonásával szignifikáns modellt kaptam $(\mathrm{F}(1,796)=26,004, \mathrm{p}=0,000)$, amely 6,8\%-ot magyaráz a környezeti identitás varianciájából. A második szakaszban az értékek bevonásával további 13,6\%-kal nőtt a modell magyarázó ereje. Az alkotás érzése 11,3\%-kal növelte az $\mathrm{R}^{2}$-et, az Önbecsülés bevonásával további 1,9\%-kal emelkedett, majd a Biztonság érték modellbe lépésével az $\mathrm{R}^{2}$ további $0,4 \%-k a 1$ emelkedett. Mindhárom modell esetében a változás szignifikáns volt $(F(1,795)=110,598 \mathrm{p}=0,000 ; \mathrm{F}(1,794)=20,104 \mathrm{p}=0,000 ; \mathrm{F}(1,793)=4,938 \mathrm{p}=0,027)$.

Az összes független változó bevonása után a demográfiai változók mellett a Biztonság, az Önbecsülés és Az alkotás érzése értékek bizonyultak szignifikáns előrejelzőnek a

\footnotetext{
${ }^{26}$ A változók bevonásához stepwise módszert alkalmaztunk.
} 
környezeti identitás számára. A legfontosabb változó a $\beta$-mutató alapján az Alkotás érzése, ezt követi a nem majd az Önbecsülés hatása. Összesen a modell a variancia 20,4\%-át magyarázza. A Biztonság hatása a legkisebb, ami azzal is indokolható, hogy ez az érték erős kapcsolatban van az életkorral. Az életkor emelkedésével válik egyre fontosabb értékké a Biztonság, míg a fiatalok számára a Szórakozás és az élet élvezete érték kiemelt fontosságú ${ }^{27}$.

Hazai kutatások az értékek hatását a környezeti attitüdre (Sudbury-Riley és tsai., 2014) és a környezettudatos viselkedésre (Nagy és tsai., 2012) vizsgálták már lineáris regresszióval. A viselkedésre pozitív hatással a Jó kapcsolat másokkal és az Alkotás érzése volt, míg negatív irányú hatást találtak az Elismertség és a környezetbarát viselkedés között. Jelen kutatásban a Biztonság, mint a legfontosabb érték a magyar lakosság számára a többi értékhez képest kisebb, de szignifikáns hatást mutat a Környezeti identitásra. Hazai szenior mintán végzett kutatás eredményei is azt mutatták (Sudbury-Riley és tsai., 2014), hogy egyedül a Biztonságnak volt hatása a környezeti attitüdre. Ez az eredmény tovább erősíti a jelen kutatás során is feltárt korral való összefüggését az értékeknek. Az eltérés emellett támogathatja a Környezeti identitás és az attitűd megkülönböztetését is, a Biztonság attitűdre gyakorolt erősebb hatásából látható, hogy az attitűd (NEP skálával mérve) fogalmában az aggodalom erősebb szerepet játszik, amely indokolja a Biztonság kiemelkedő hangsúlyát.

Az Alkotás érzése és az Önbecsülés belső értékek, amely azt mutatja - hasonlóan a környezettudatos viselkedéshez - hogy a környezeti identitás akkor erösebb, ha magasabb szintű motivációk és belső(vé tett) értékek hajtják.

A Biztonság a külső értékek közé tartozik, a modellben való megjelenése azonban véleményem szerint azzal indokolható, hogy a magyar értékrendben ennek az értéknek van a legerősebb szerepe.

A H3-as hipotézis az eredmények alapján részben nyert megerősítést, hiszen a 3 szignifikáns hatással lévő érték közül a két legnagyobb hatással lévő érték a belső értékek közé tartozik.

\footnotetext{
27 Jelen kutatásban a Szórakozás és az élet élvezete értéknek nem volt szignifikáns kapcsolata a Környezeti identitással, de az Elismertség értékkel együtt több modellben is negatív kapcsolatot mutat.
} 


\section{6 ÚTELEMZÉS: A KÖRNYEZETI IDENTITÁS HATÁSA A KÖRNYEZETBARÁT VISELKEDÉSRE}

A disszertáció elemzésem fő kérdése, a környezeti identitás gyakorlati hasznosságának az igazolása azáltal, hogy a környezetbarát viselkedésre való hatását vizsgálom és igazolom. Amennyiben a környezeti identitásnak mérhető hatása van a környezetbarát viselkedésre, az azt jelzi, hogy a jövőben a társadalmi marketing kampányoknak nem elégséges a környezeti attitűdre, vagy a környezeti aggodalomra fókuszálni, hanem a természettel való erős kapcsolat kialakítását kell célul kitűzni, a környezetbarát fogyasztók (fel)nevelése érdekében.

A környezeti identitás és a környezettudatos viselkedés kapcsolatának elemzésére regressziós útmodellel dolgoztam. Az útmodell egymásra épülő regressziós modellek sorozata (Székelyi és Barna, 2008). Ezekből a regressziós egyenletekből következtethetünk a változók közötti összefüggésre. Az útelemzés abból indul ki, hogy az egyik változó értékeit más változók értékei okozzák, tehát elengedhetetlen függő és független változók megkülönböztetése (Babbie, 2001). A függő változó az útmodell azon eleme, amelybe más változókból utak vezetnek be. A függő változót más néven endogén változónak nevezzük. A független változó esetében exogén változóról beszélünk, amelybe egyetlen másik változóból sem vezet út. Egy útmodellhez annyi regressziós egyenlet tartozik, ahány függő változót tartalmaz a modell.

Kutatásunkban az alábbi változók összefüggésit vizsgáljuk (lásd 11. ábra elméleti modell):

- endogén változó: környezettudatos viselkedés, környezeti attitüd, környezeti aggodalom és személyes norma

- exogén változó: környezeti identitás.

Az útelemzés a kapcsolatok oksági rendjét nem határozza meg, a változók közötti lehetséges kapcsolatokat a kutató definiálja a szakirodalom alapján. A változók közötti kapcsolatok indoklását a hipotézisek bemutatása során ismertettem. A 16. ábra a regressziós modell és a hipotézisek kapcsolatát mutatja be. 


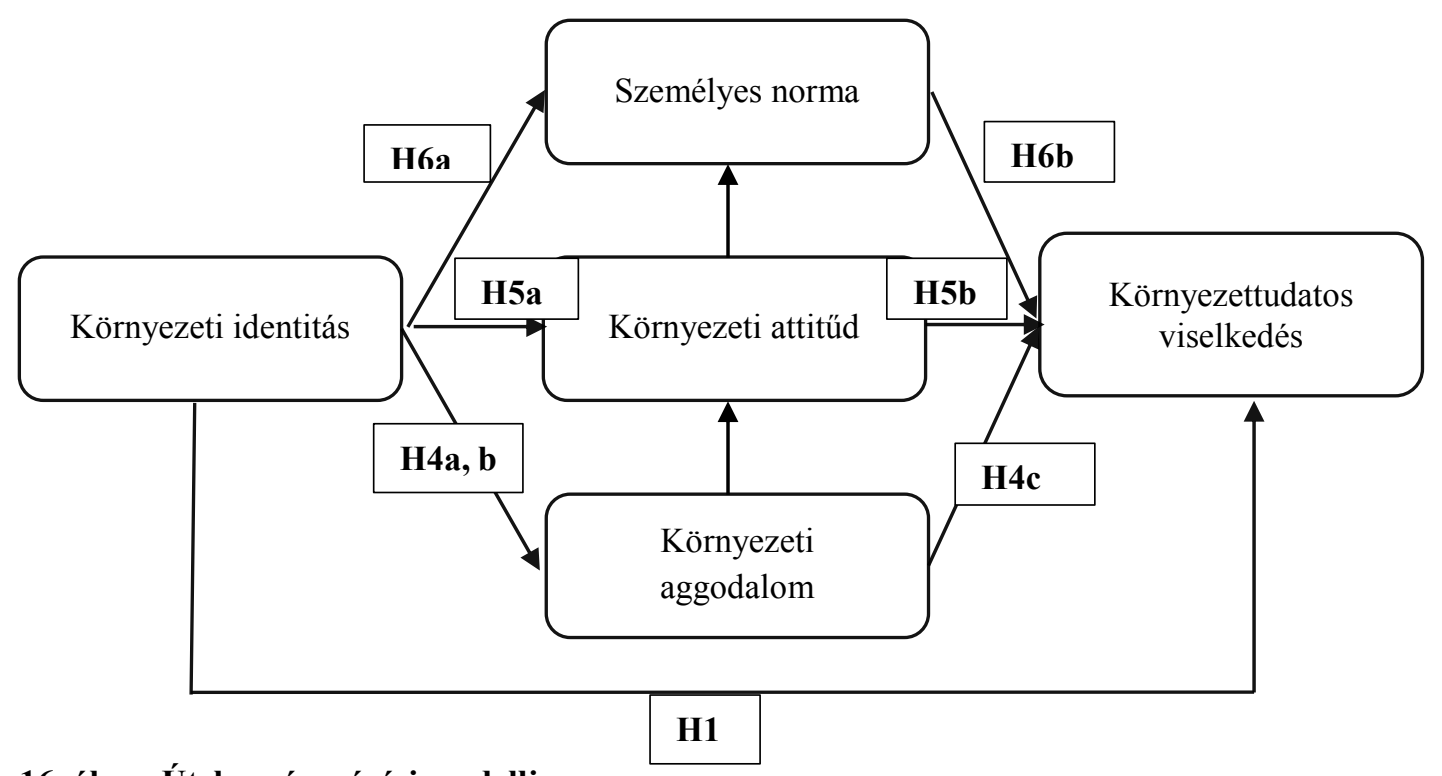

16. ábra: Útelemzés mérési modellje

Forrás: saját szerkesztés

A regressziós elemzésekhez a parciális F-próba stepwise módszert alkalmaztam. A módszer a változók modellbe építése során a parciális korrelációs együtthatókat veszi figyelembe. Így megtörténhet az, hogy egy változó a többi változó modellbe építésével a kiinduló szignifikáns hatása után mégis kikerül az egyenletből (Székelyi és Barna, 2008). A stepwise technika kutatásom során használható, mert a mintanagyság jóval nagyobb, a magyarázó változók számánál.

A modell hátrányaként említhető, hogy a magyarázó változók közötti korreláció miatt az elmélet alapján fontos változók kieshetnek, míg a nem hangsúlyos változók bekerülhetnek a modellbe (Sajtos és Mitev, 2007). A lehetséges negatív következmények elkerülésére az elemzés során figyeltem arra, hogy a szakirodalom alapján javasolt logikai kapcsolatok megjelenését nyomon kövessem, valamint a regresszió alapfeltételeinek meglétét minden egyenlet esetében ellenőriztem.

A modellek linearitásának vizsgálatára elöször a modellbe bevont változókat a „curve estimation” (görbe becslési) illeszkedésvizsgálattal elemeztem. Az F-próba szignifikancia szintjei (Sig. < 0,01) minden esetben a lineáris kapcsolat meglétét igazolta (lásd melléklet).

\subsubsection{MÉRÉSI SKÁLÁK BEMUTATÁSA}

A regressziós modell kialakításához először megvizsgáltam a mérésre használt skálákat a megbízhatóságuk szempontjából. A következőkben tömören bemutatom az alkalmazott skálákat felépítésük és skálaérték számítási módszerük szempontjából. A 
megbízhatósági eredményeket a 21. táblázat foglalja össze, amelyből látható, hogy a skálák alkalmasak a modellbe való beépítésre.

\begin{tabular}{|l|c|c|c|}
\hline Skála & Skála átlag & Szórás & Cronbach-alfa \\
\hline Általános Környezeti Viselkedés Skála & 21,63 & 5,928 & 0,792 \\
\hline Új Környezeti Paradigma Skálát & 59,34 & 7,777 & 0,757 \\
\hline Stern-féle Személyes Norma Skála & 4,33 & 0,582 & 0,872 \\
\hline Egyéni felelősségre vonatkozó norma & 3,98 & 0,846 & 0,839 \\
\hline Kormányzati felelösségre vonatkozó norma & 4,50 & 0,644 & $0,809^{28}$ \\
\hline Vállalati felelősségre vonatkozó norma & 4,51 & 0,564 & $0,625^{29}$ \\
\hline Schultz Környezeti Motívumok Skála & 5,76 & 1,013 & 0,953 \\
\hline Bioszférikus aggodalom & 5,63 & 1,186 & 0,942 \\
\hline Altruista aggodalom & 5,92 & 1,058 & 0,911 \\
\hline Egoista aggodalom & 5,72 & 1,109 & 0,898 \\
\hline
\end{tabular}

21. táblázat: Modellben alkalmazott skálák megbízhatósági vizsgálata

Forrás: saját elemzés

A környezetbarát viselkedés vizsgálatára alkalmas az Általános Környezeti Viselkedés Skála (General Ecological Behavior, GEB, Kaiser és Wilson, 2004). Kaiser 1998-ban mérőeszközt dolgozott ki a környezetbarát magatartás mérésére a célorientált viselkedés elve alapján, az ún. Általános Ökológiai Magatartás skálát (GEB). A skála 50 állítást tartalmaz a környezetbarát cselekvésekre vonatkozóan, amelyből 32 állítást 5 fokú Likert skálával mérnek, 18-at pedig igen - nem változóként. A válaszadóknak lehetőségük volt a „,nem vonatkozik rám” opció kiválasztása, amelyet az elemzések során a szerzők javaslatára nem válaszként kell kódolni.

A skála 7 alskálából áll: környezettudatos közlekedés (12 állítás), társadalomnak hasznos környezetbarát viselkedések (9 állítás), környezettudatos fogyasztói viselkedés ( 9 állítás), víz és energiatakarékos fogyasztás (11 állítás), hulladék csökkentése (5 állítás), szelektív hulladékgyüjtés (4 állítás).

A skálát kétféleképp javasolják a szerzők elemzésre:

- az állítások dummy változóvá alakítása után score-ok számításával a válaszadókra, amely során a magasabb score a környezettudatosabb viselkedésre utal

\footnotetext{
${ }^{28}$ A Cronbach alfa mutató javítható lenne, ha kivennénk az alábbi állítást: A kormánynak nemzetközi szinten kell nyomást gyakorolnia az élővilág sokszínüségének csökkenése (fajok kihalása, élőhelyek és a vadvilág pusztulása) ellen. Véleményem szerint a nemzetközi szintre való kihelyezése a felelősségnek ad az állításnak egy plusz háttérdimenziót.

${ }^{29}$ A kormány felelősségéhez hasonlóan a Cronbach alfa mutató javítható lenne, ha kivennénk a nemzetközi szintre vonatkozó állítást: Azok a vállalatok, amelyek távoli országokból termékeket importálnak, felelősek a távoli országokban jelenlévő élővilág csökkenésének a megakadályozásáért.
} 
- illetve a Rasch modell használatával a cselekvések nehézsége is figyelembe vehetö.

Jelen tanulmányban a GEB skála pontértékei alapján határozzuk meg a környezettudatosság mértékét minden válaszadó esetében. A GEB skála értéke a negatív irányú kérdések átalakítása után kapott értékek összegzését jelenti. Így a GEB minimumértéke 0 , a maximum pedig 50 pont lehet.

A 3.4.2-es fejezetben bemutatásra került az Új környezeti Paradigma Skálát (NEP, Dunlap és tsai., 2000) alkalmaztuk a környezeti attitüd vizsgálatára. Annak ellenére, hogy a skála 5 föbb témakört vizsgál a környezeti világnézet kapcsán (a növekedés határainak elismerése, anti-antropocentrizmus (emberközpontúság elvetése), a természeti egyensúly törékenységében való hit, az emberi kiváltságosság elutasítása (anti-exempcionalizmus), és az ökokrízis bekövetkezésének lehetősége), a szerzők a feltáró faktorelemzés alapján egy dimenziós konstrukciónak kezelik (Dunlap és tsai., 2000). Ebből kiindulva elemzésünk során a skálát teljes egységében alkalmazzuk. A NEP skála elemzéséhez a kutatások a NEP skála értékét az összes állítás összegzéséből számítják (Hawcroft és Milfont, 2010). Így a minimum értéke a NEP értéknek 15, a maximum 75 pont lehet.

A normák vizsgálatát Stern-féle Személyes Norma (Personal Norm, Stern és tsai., 1999) skálájának felhasználásával mértük. A személyes norma az egyéni kötelezettség érzése, amely egyéni elvárássá válik (Schwartz, 1977). Az egyéni kötelességérzés adhat alapot a környezetbarát cselekvés kialakulásának (Stern és tsai., 1999), ezért Stern és kollégái felhasználták a Schwartz-féle norma- aktiválási elméletet és a személyes normához kötődő állításokat. 9 állítással mérik a normatív hiedelmeket, 3 a személyes kötelességre vonatkozik, 3 az állam és 3 a vállalatok kötelességeire. A három alskála eltérő cselekvésre gyakorolt hatása miatt érdemes külön is vizsgálni az alskálákat.

\section{A környezeti aggodalom mérésére Schultz (2001) Környezeti Motívumok} (Environmental Motives Scale, EMS) skáláját alkalmaztuk. A skála célja a környezet iránti aggodalom vizsgálata aszerint, hogy kikre, illetve mikre gyakorol hatást a környezet rongálása. A környezeti aggodalmat jelen esetben három alskálára bontja a szerző (Schultz, 2001): 
- egoista (azaz ha az aggodalom önmagunkra, a jövőnkre, az életstílusunkra illetve az egészségünkre van hatása a környezetszennyezésnek),

- altruista (azaz ha az aggodalom általában minden emberre, a gyerekekre, a saját gyerekeinkre és az országunkban élő emberekre vonatkozik),

- és bioszférikus aggodalomra (azaz ha az aggodalom a növényekre, állatokra, tengeri élőlényekre és a madarakra vonatkozik).

A skála esetében is a skálaérték átlag alapján történő számítását javasolja a szerző az elemzésekhez (Schultz, 2001), és 7-fokú Likert skálán mérik általában az állításokat. Az alskálákhoz számításához az elemzésekben a skálaértékek átlagának használatát javasolják a szerzők ${ }^{30}$.

Összefoglalva tehát a kiinduló megbízhatósági elemzés a skálák alkalmazhatóságát támogatja.

\subsubsection{VIZSGÁLT REGRESSZIÓS MODELLEK}

A bemutatott modell alapján nyolc regressziós egyenlettel dolgoztam (a személyes normát és a környezeti aggodalmat alskálákra bontva vizsgáltam).

A környezetbarát viselkedés, a függő változó becslése a négy modellbe vont változó által az alábbi egyenlet szerint történt:

$$
\begin{aligned}
G E B= & \beta_{1} * E I D+\beta_{2} * N E P+\beta_{3} * P N_{\text {gov }}+\beta_{4} * P N_{\text {org }}+\beta_{5} * P N_{\text {ego }}+\beta_{6} * E M S_{\text {bio }}+\beta_{7} \\
& * E M S_{\text {altr }}+\beta_{8} * E M S_{\text {ego }}+\text { Resid }_{1}
\end{aligned}
$$

A regresszió elemzés elvégzéséhez biztosítani kell a függő és a független változó közötti multikollinearitás alacsony mértékét. A multikollinearitást vizsgáló mutatók (Tolerancia $>0,1 ; \mathrm{VIF}<10$ ) megfelelnek a kritériumoknak (Hair és tsai., 2010), ezért a változók közötti multikollinearitás elhanyagolható. A reziduálisok függetlenségének az ellenőrzésére alkalmas a Durbin-Watson mutató, amely jelen esetben az autokorreláció elhanyagolhatóan csekély voltát mutatja (Durbin-Watson=1,902). A homoszkedaszticitás ellenőrzésére alkalmas scatterplot ábra megfelelö tömörülést mutat, valamint a normalitás feltételének ellenőrzésére alkalmas hisztogram és ábra is megfelelő alakot és szoros illeszkedést mutat (lásd melléklet).

\footnotetext{
${ }^{30} \mathrm{http}: / /$ www.conpsychmeasures.com/scales/EMS.html
} 
A stepwise módszerrel történt regresszió esetében négy változó hatása bizonyult szignifikánsnak, a környezeti identitás, a környezeti attitűd és a személyes felelősségre vonatkozó norma és a vállalatok felelősségére vonatkozó norma.

\begin{tabular}{|c|c|c|c|c|c|c|c|}
\hline & & B & $\beta^{l}$ & $\mathrm{t}$ & $\mathrm{R}^{2}$ & $\begin{array}{c}\text { Adjusted } \\
\mathrm{R}^{2}\end{array}$ & $\mathrm{~F}$ \\
\hline Első lépés & Környezeti identitás (EID) & ,224 & ,446 & $13,606 * *$ & , 199 & ,198 & $185,126 * *$ \\
\hline \multirow{2}{*}{$\begin{array}{l}\text { Második } \\
\text { lépés }\end{array}$} & Környezeti identitás (EID) & ,191 &, 380 & $10,980 * *$ & \multirow{2}{*}{,227 } & \multirow{2}{*}{,225 } & \multirow{2}{*}{$109,617^{* *}$} \\
\hline & Környezeti attitüd (NEP) & 148 &, 181 & $5,247 * *$ & & & \\
\hline \multirow{3}{*}{$\begin{array}{l}\text { Harmadik } \\
\text { lépés }\end{array}$} & Környezeti identitás (EID) &, 151 & ,300 & $7,237 * *$ & \multirow{3}{*}{,239 } & \multirow{3}{*}{ 236 } & \multirow{3}{*}{$77,999 * *$} \\
\hline & Környezeti attitüd (NEP) &, 135 &, 166 & $4,793 * *$ & & & \\
\hline & $\begin{array}{l}\text { Személyes norma/ } \\
\text { személyes felelösség }\left(\mathrm{PN}_{\text {ego }}\right)\end{array}$ & ,974 & ,139 & $3,411^{* *}$ & & & \\
\hline \multirow{4}{*}{$\begin{array}{l}\text { Negyedik } \\
\text { lépés }\end{array}$} & Környezeti identitás (EID) & 157 & ,312 & $7,466^{* *}$ & \multirow{4}{*}{ 243 } & \multirow{4}{*}{ 239 } & \multirow{4}{*}{$59,747 * *$} \\
\hline & Környezeti attitüd (NEP) &, 147 &, 181 & $5,122 * *$ & & & \\
\hline & $\begin{array}{l}\text { Személyes norma/ } \\
\text { személyes felelösség }\left(\mathrm{PN}_{\text {ego }}\right)\end{array}$ & 1,216 &, 174 & $3,931 * *$ & & & \\
\hline & $\begin{array}{l}\text { Személyes norma/ } \\
\text { Vállalatok felelőssége }\left(\mathrm{PN}_{\text {org }}\right)\end{array}$ &,- 858 &,- 082 & $-2,009^{*}$ & & & \\
\hline
\end{tabular}

${ }^{*} \mathrm{p}<0.05 .{ }^{* *} \mathrm{p}<0.001$

22. táblázat: Többváltozós lineáris regresszió eredménye a környezettudatos viselkedés vizsgálatára

Forrás: saját elemzés

Az első lépésben a környezeti identitás bevonásával a modell 19,8\%-ot magyaráz a környezetbarát viselkedés varianciájából. A második lépésben a környezeti attitűd belépésével a modell tovább erősödött, 22,5\%-os magyarázó erőre, és ez az $\mathrm{R}^{2}$ változás szignifikáns $(\mathrm{F}(1,746)=27,532 ; \mathrm{p}=0,000)$. A személyes felelősségre vonatkozó norma bevonásával a modell magyarázó ereje további 1,2\%-kal nőtt. A modellek közötti változás ebben az esetben is szignifikáns $(\mathrm{F}(1,745)=11,637 ; \mathrm{p}=0,000)$. A vállalatok felelősségére vonatkozó norma csekély, 0,4\% plusz varianciát jelent, azonban a modellek közötti változás még ebben az esetben is szignifikáns $(\mathrm{F}(1,745)=11,637$; $\mathrm{p}=0,000$ ). Összesen a modell a variancia $23,9 \%$-át magyarázza.

A regressziós egyenlet a következö:

$G E B=0,312 * E I D+0,181 * N E P+0,174 * P N_{\text {ego }}-0,082 * P N_{\text {org }}$ 
A legfontosabb változó a $\beta$-mutató alapján a környezeti identitás, majd a környezeti attitüd. Az eredmények azt igazolják, hogy a környezeti aggodalomnak csupán a környezeti attitüdön keresztül van hatása, közvetlen hatást nem gyakorol a környezetbarát viselkedésre.

A személyes norma esetében a személyes felelősségnek van szignifikáns, pozitív hatása a környezetbarát viselkedés mértékére, míg a vállalatok felelősségének enyhe negatív hatása van a környezetbarát viselkedésre. A negatív kapcsolat mögött véleményem szerint a felelősség hárításának lehetősége áll. Amennyiben a vállalatok felelősségét hangsúlyozza az egyén, akkor a saját helyzetét kötöttebbnek, függőbbnek éli meg a vállalat tevékenységétől. Így az egyén észlelt hatékonysága is csökkenhet, amely rontja a környezetbarát tevékenységekben való aktivitás és cselekvési szándék mértékét.

A környezeti attitüd magyarázatára a bemutatott elméletek alapján a környezeti identitást és a környezeti aggodalom három alskáláját vizsgáltam. A regressziós modell felépítése:

$N E P=\gamma_{1} * E I D+\gamma_{2} * E M S_{\text {bio }}+\gamma_{3} * E M S_{\text {altr }}+\gamma_{4} * E M S_{\text {ego }}+$ Resid $_{2}$

A regresszió elemzés feltételei a mutatószámok vizsgálata alapján teljesülnek és az egyenlet alkalmas az elemzésre. Alacsony multikollinearitás figyelhető meg a függő és a független változók között (Tolerancia $>0,1 ; \quad \mathrm{VIF}<10)$. A reziduálisok függetlenségének az ellenőrzésére alkalmazott a Durbin-Watson mutató értéke 2,078 amely az autokorreláció elhanyagolhatóan csekély voltát mutatja. A homoszkedaszticitás és a normalitás feltételei teljesülnek a scatterplot megfelelő tömörülést mutat illetve a normalitás grafikus vizsgálatai megfelelő alakúak és szoros illeszkedésűek (lásd melléklet).

Két változó hatása szignifikáns a környezeti attitüdre vonatkozóan, a környezeti identitás és a bioszférikus aggodalom, azaz a természetre vonatkozó aggodalom. A környezeti attitűdre a környezeti aggodalom erösebb hatással, mint a környezeti identitás. A bioszférikus aggodalom 15,3\%-ban magyarázza a környezeti attitüd varianciáját. A környezeti identitás beemelésével a modell magyarázó ereje 17,6\%-ra emelkedik. Ez az $\mathrm{R}^{2}$ változás szignifikáns különbséget jelent a két egyenlet között $(\mathrm{F}(1,746)=22,263 ; \mathrm{p}=0,000)$. 


\begin{tabular}{|c|c|c|c|c|c|c|c|}
\hline & & B & $\beta^{l}$ & $\mathrm{t}$ & $\mathrm{R}^{2}$ & $\begin{array}{c}\text { Adjusted } \\
\mathrm{R}^{2}\end{array}$ & $\mathrm{~F}$ \\
\hline Első lépés & $\begin{array}{l}\text { Bioszférikus aggodalom } \\
\left(\mathrm{EMS}_{\mathrm{bio}}\right)\end{array}$ & 2,412 & ,393 & $11,669 * *$ & ,154 & 153 & $136,169 * *$ \\
\hline \multirow[t]{2}{*}{$\begin{array}{l}\text { Második } \\
\text { lépés }\end{array}$} & $\begin{array}{l}\text { Bioszférikus aggodalom } \\
\left(\text { EMS }_{\text {bio }}\right)\end{array}$ & 1,665 &, 271 & $6,448 * *$ & \multirow[t]{2}{*}{, 179} & \multirow[t]{2}{*}{, 176 } & \multirow[t]{2}{*}{$81,154 * *$} \\
\hline & Környezeti identitás (EID) &, 123 & 198 & $4,718^{* *}$ & & & \\
\hline
\end{tabular}

${ }^{*} \mathrm{p}<0.05 .{ }^{* *} \mathrm{p}<0.001$

23. táblázat: Többváltozós lineáris regresszió eredménye a környezeti attitüd vizsgálatára Forrás: saját elemzés

A környezeti attitüdre vonatkozó regressziós egyenlet a következő:

$N E P=0,198 * E I D+0,271 * E M S_{b i o}$

A NEP által mért környezeti attitűdre tehát kutatásunk során csak a bioszférikus aggodalom hatását tudtuk kimutatni. Sem az egoista, sem az altruista aggodalom nincs szignifikáns hatással. Ezt az eredményt a NEP felépítése magyarázza, mert a NEP állítások az ökológiai katasztrófa lehetőségét és a természeti környezet veszélyeztetettségét hangsúlyozza, így az önmagunkért és az embertársainkért való aggodalom kevésbé jelenik meg benne.

A környezeti aggodalom esetében - a felállított elméleti modell alapján - a környezeti identitás hatását vizsgáltam. Annak érdekében, hogy a felállított $\mathrm{H} 4 \mathrm{~b}$ hipotézist igazoljam, annak ellenére, hogy a környezeti aggodalomnak nincs közvetlen hatása a környezettudatos viselkedésre, a környezeti identitás hatását mind a három aggodalom típus esetében megvizsgáltam.

A regressziós egyenletek a következök:

$$
\begin{aligned}
& E M S_{\text {bio }}=\delta_{1} * E I D+\text { Resid }_{3} \\
& E M S_{\text {altr }}=\delta_{2} * E I D+\text { Resid }_{4} \\
& E M S_{\text {ego }}=\delta_{3} * E I D+\text { Resid }_{5}
\end{aligned}
$$

A regressziós modellek megfelelnek az előfeltételeknek (részletes eredmények a mellékletben ${ }^{31}$ ). A környezeti identitás szignifikáns hatással van mind a három típusú

\footnotetext{
${ }^{31}$ A lineáris regresszió a normalitás, a linearitás és a szórások állandóságának megsértésére robosztus, alapvetően korrekt módon használható ezeket a feltételeket "nem nagyon" sértő esetekben (Freedman és tsai., 2007). $\mathrm{Az} \mathrm{EMS}_{\mathrm{altr}}, \mathrm{EMS}_{\mathrm{ego}}, \mathrm{PN}_{\mathrm{org}}$ és $\mathrm{PN}_{\mathrm{gov}}$ esetében a normalitás feltétele kissé sérül, amelyet az eredmények értékelésénél figyelembe kell venni.
} 
aggodalomra. A modellek magyarázó ereje azonban — várakozásaimnak megfelelően - eltérő, 20,7\% és 37,6\% között mozog.

\begin{tabular}{|c|c|c|c|c|c|c|c|c|}
\hline & B & $\beta^{l}$ & $\mathrm{t}$ & $\mathrm{R}^{2}$ & $\begin{array}{c}\text { Adjusted } \\
\mathrm{R}^{2}\end{array}$ & $\mathrm{~F}$ & Tol. & $\begin{array}{l}\text { Durbin- } \\
\text { Watson }\end{array}$ \\
\hline \multicolumn{9}{|c|}{ Bioszférikus aggodalom (EMS bio ) } \\
\hline Környezeti identitás (EID) &, 062 & ,614 & $21,245 * *$ &, 377 & ,376 & $451,336^{* *}$ & 1,000 & 1,947 \\
\hline \multicolumn{9}{|l|}{ Altruista aggodalom $\left(\mathrm{EMS}_{\text {altr }}\right)$} \\
\hline Környezeti identitás (EID) & ,049 &, 547 & $17,861 * *$ & ,299 & ,298 & $318,998 * *$ & 1,000 & 2,093 \\
\hline \multicolumn{9}{|l|}{ Egoista aggodalom $\left(\right.$ EMS $\left._{\text {ego }}\right)$} \\
\hline Környezeti identitás (EID) &, 043 & ,456 & $14,011^{* *}$ & ,208 & ,207 & $196,313 * *$ & 1,000 & 2,080 \\
\hline
\end{tabular}

${ }^{*} \mathrm{p}<0.05 .{ }^{* * \mathrm{p}}<0.001$

24. táblázat: Többváltozós lineáris regresszió eredménye a környezeti aggodalom vizsgálatára

Forrás: saját elemzés

A regresszió eredményei alátámasztják a hipotézisemet, miszerint a környezeti identitásnak a bioszférikus aggodalomra van a legnagyobb hatása 37,6\% magyarázott varianciával. Ezt követi az emberek, a társadalom iránti aggodalomra gyakorolt hatás $\left(\mathrm{R}^{2}=29,8 \%\right)$, és végül az önmagunk miatti aggodalom $\left(\mathrm{R}^{2}=20,8 \%\right)$.

Az útmodellben alkalmazott környezeti aggodalom regressziós egyenletei az alábbiak:

$E M S_{\text {bio }}=0,614 * E I D$

$E M S_{\text {altr }}=0,547 * E I D$

$E M S_{\text {ego }}=0,456 * E I D$

A személyes norma esetében a környezeti attitüd és a környezeti identitás hatását vizsgáltam a lineáris regresszió segítségével. Jelen elemzésben a személyes és a vállalati felelősségre vonatkozó norma bizonyult szignifikáns hatásúnak a környezetbarát viselkedésre, de a környezeti identitás hatásainak a széleskörü megértése érdekében továbbra is mindhárom norma típussal foglalkozom.

$$
\begin{aligned}
& P N_{\text {ego }}=\zeta_{1} * E I D+\zeta_{2} * N E P+\zeta_{3} * E M S_{\text {bio }}+\zeta_{4} * E M S_{\text {altr }}+\zeta_{5} * E M S_{\text {ego }}+\text { Resid }_{6} \\
& P N_{\text {gov }}=\theta_{1} * E I D+\theta_{2} * N E P+\theta_{3} * E M S_{\text {bio }}+\theta_{4} * E M S_{\text {altr }}+\theta_{5} * E M S_{\text {ego }}+\text { Resid }_{7} \\
& P N_{\text {org }}=\xi_{1} * E I D+\xi_{2} * N E P+\xi_{3} * E M S_{\text {bio }}+\xi_{4} * E M S_{\text {altr }}+\xi_{5} * E M S_{\text {ego }}+\text { Resid }_{8}
\end{aligned}
$$

A regresszió alkalmas a vizsgálatra, az előfeltételek teljesülése biztosított (Tolerancia $>0,1 ; \quad \mathrm{VIF}<10 ; \quad$ Durbin-Watson $\quad\left(P N_{\text {ego }}\right)=1,980 ; \quad$ Durbin-Watson $\left(P N_{\text {gov }}\right)=2,073$; Durbin-Watson $\left.\left(P N_{\text {org }}\right)=2,039\right)$. Az eredményeket a 25 . táblázatban foglaltam össze. 


\begin{tabular}{|c|c|c|c|c|c|c|c|}
\hline & & B & $\beta^{l}$ & $\mathrm{t}$ & $\mathrm{R}^{2}$ & $\begin{array}{l}\text { Adjusted } \\
\mathrm{R}^{2}\end{array}$ & $\mathrm{~F}$ \\
\hline \multicolumn{8}{|c|}{ Személyes norma - Személyes felelőssége } \\
\hline Első lépés & Környezeti identitás (EID) & 044 & 612 & $21,135 * *$ & ,374 &, 373 & $446,700 * *$ \\
\hline \multirow{2}{*}{$\begin{array}{l}\text { Második } \\
\text { lépés }\end{array}$} & Környezeti identitás (EID) & ,032 & ,443 & $12,565^{* *}$ & \multirow{2}{*}{, 421} & \multirow{2}{*}{, 420} & \multirow[b]{2}{*}{$271,403 * *$} \\
\hline & $\begin{array}{l}\text { Bioszférikus } \quad \text { aggodalom } \\
\left(\mathrm{EMS}_{\mathrm{bio}}\right)\end{array}$ &, 196 & ,274 & $7,779 * *$ & & & \\
\hline \multirow{3}{*}{$\begin{array}{l}\text { Harmadik } \\
\text { lépés }\end{array}$} & Környezeti identitás (EID) & ,031 & ,425 & $11,933 * *$ & \multirow{3}{*}{,428 } & \multirow{3}{*}{,426 } & \multirow{3}{*}{$185,779 * *$} \\
\hline & $\begin{array}{l}\text { Bioszférikus } \quad \text { aggodalom } \\
\left(\mathrm{EMS}_{\mathrm{bio}}\right)\end{array}$ &, 137 &, 193 & $4,317 * *$ & & & \\
\hline & Altruista aggodalom $\left(\mathrm{EMS}_{\mathrm{altr}}\right)$ &, 100 &, 125 & $2,972 *$ & & & \\
\hline \multicolumn{8}{|c|}{ Személyes norma - Kormányzat felelőssége } \\
\hline Első lépés & $\begin{array}{l}\text { Bioszférikus } \\
\left(\mathrm{EMS}_{\mathrm{bio}}\right)\end{array}$ & ,236 & ,434 & $13,169 * *$ &, 188 &, 187 & $173,416^{* *}$ \\
\hline \multirow[t]{2}{*}{$\begin{array}{l}\text { Második } \\
\text { lépés }\end{array}$} & $\begin{array}{l}\text { Bioszférikus } \quad \text { aggodalom } \\
\left(\mathrm{EMS}_{\text {bio }}\right)\end{array}$ &, 149 & ,274 & $6,741 * *$ & \multirow[t]{2}{*}{, 231} & \multirow[t]{2}{*}{,229 } & \multirow[t]{2}{*}{$111,876^{* *}$} \\
\hline & Környezeti identitás (EID) & ,014 & ,261 & $6,406 * *$ & & & \\
\hline \multirow[t]{3}{*}{$\begin{array}{l}\text { Harmadik } \\
\text { lépés }\end{array}$} & $\begin{array}{l}\text { Bioszférikus } \quad \text { aggodalom } \\
\left(\mathrm{EMS}_{\mathrm{bio}}\right)\end{array}$ &, 124 & ,228 & $5,529 * *$ & \multirow{3}{*}{,255 } & \multirow{3}{*}{,252 } & \multirow{3}{*}{$85,018 * *$} \\
\hline & Környezeti identitás (EID) &, 012 & ,226 & $5,571 * *$ & & & \\
\hline & Környezeti attitüd (NEP) & 015 &, 172 & $4,930 * *$ & & & \\
\hline \multirow[t]{4}{*}{$\begin{array}{l}\text { Negyedik } \\
\text { lépés }\end{array}$} & $\begin{array}{l}\text { Bioszférikus } \quad \text { aggodalom } \\
\left(\mathrm{EMS}_{\text {bio }}\right)\end{array}$ & ,083 &, 154 & $2,996^{*}$ & \multirow{4}{*}{,261 } & \multirow{4}{*}{,257 } & \multirow{4}{*}{$65,602 * *$} \\
\hline & Környezeti identitás (EID) & 012 &, 211 & $5,135 * *$ & & & \\
\hline & Környezeti attitűd (NEP) & 015 &, 167 & $4,794 * *$ & & & \\
\hline & Altruista aggodalom $\left(\mathrm{EMS}_{\text {altr }}\right)$ &, 070 &, 115 & $2,394 *$ & & & \\
\hline \multicolumn{8}{|c|}{ Személyes norma - Vállalatok felelőssége } \\
\hline Első lépés & $\begin{array}{l}\text { Bioszférikus } \\
\left(\mathrm{EMS}_{\mathrm{bio}}\right)\end{array}$ & ,235 & ,493 & $15,505 * *$ & ,243 & ,242 & $240,413 * *$ \\
\hline \multirow[t]{2}{*}{$\begin{array}{l}\text { Második } \\
\text { lépés }\end{array}$} & $\begin{array}{l}\text { Bioszférikus } \\
\left(\text { EMS }_{\text {bio }}\right)\end{array}$ &, 153 & ,323 & $8,269 * *$ & \multirow[t]{2}{*}{,292 } & \multirow[t]{2}{*}{,290 } & \multirow[t]{2}{*}{$153,634 * *$} \\
\hline & Környezeti identitás (EID) & 013 & ,278 & $7,129 * *$ & & & \\
\hline \multirow[t]{3}{*}{$\begin{array}{l}\text { Harmadik } \\
\text { lépés }\end{array}$} & $\begin{array}{l}\text { Bioszférikus } \\
\left(\mathrm{EMS}_{\mathrm{bio}}\right)\end{array}$ &, 130 & ,274 & $6,958 * *$ & \multirow{3}{*}{,318 } & \multirow{3}{*}{,316 } & \multirow{3}{*}{$115,990 * *$} \\
\hline & Környezeti identitás (EID) &, 012 & ,242 & $6,237 * *$ & & & \\
\hline & Környezeti attitűd (NEP) & ,014 &, 180 & $5,396 * *$ & & & \\
\hline $\begin{array}{l}\text { Negyedik } \\
\text { lépés }\end{array}$ & $\begin{array}{l}\text { Bioszférikus } \\
\left(\mathrm{EMS}_{\mathrm{bio}}\right)\end{array}$ & ,095 &, 199 & $4,054 * *$ & ,324 &, 321 & $89,250 * *$ \\
\hline
\end{tabular}




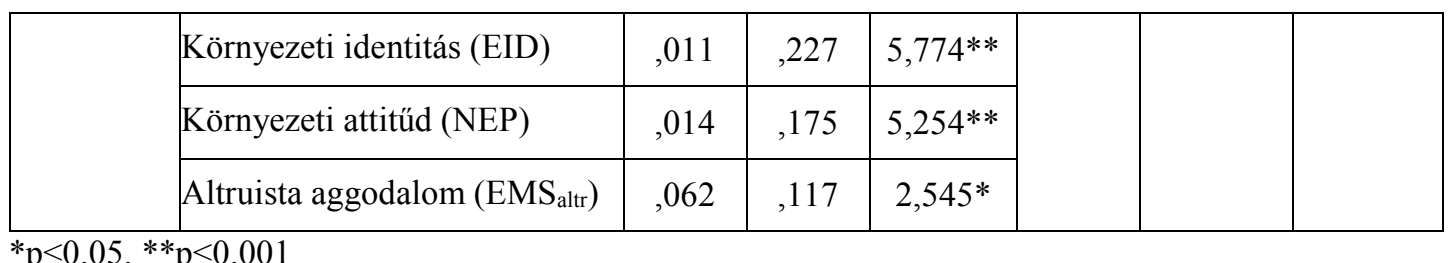

25. táblázat: Többváltozós lineáris regresszió eredménye a személyes norma vizsgálatára Forrás: saját elemzés

A személyes felelősség esetében a környezeti identitás rendelkezik a legerősebb hatással, és a személyes norma varianciájának 37,3\%-át magyarázza. Izgalmas különbség a személyes normák között, hogy a környezeti attitüd a személyes felelősségre vonatkozó norma esetében nem rendelkezik szignifikáns hatással. A bioszférikus és az altruista aggodalom modellbe vonásával a környezeti attitűd szignifikáns hatása eltünik. A végső egyenletben a magyarázott variancia 42,6\%-ra emelkedik. A bioszférikus aggodalom modellbe lépésével a variancia 4,7\%-kal nő $(\mathrm{F}(1,746)=60,516 ; \mathrm{p}=0,000)$, majd az altruista aggodalom további 0,7\%-ot tesz hozzá, amely szintén szignifikánsan eltérö modellt jelent $(F(1,745)=8,832 ; p=0,003)$ A környezeti identitásnak van a legmagasabb regressziós együtthatója, az aggodalom gyengébb, de szintén pozitív hatással rendelkezik a személyes normára.

$P N_{\text {ego }}=0,425 * E I D+0,193 * E M S_{\text {bio }}+0,125 * E M S_{\text {altr }}$

A kormányzat és a vállalatok felelősségére vonatkozó személyes norma esetében azonos változók jelennek meg szignifikáns hatással. A környezeti identitás van a legerösebb hatással, majd a NEP, és a bioszférikus aggodalom, illetve nem sokkal gyengébb hatással megjelenik az altruista aggodalom is a modellekben. A NEP megjelenése azzal indokolható, hogy a NEP-ben jelentős hangsúlyt képvisel a technológiával szembeni szkepticizmus illetve bizalom, amely az egyéni felelősségvállalásra nincs hatással, azonban szerepet játszik a kormányzat és a vállalatok felelősségének kiemelésében.

$$
\begin{aligned}
& P N_{\text {gov }}=0,211 * E I D+0,167 * N E P+0,154 * E M S_{\text {bio }}+0,115 * E M S_{\text {altr }} \\
& P N_{\text {org }}=0,227 * E I D+0,175 * N E P+0,199 * E M S_{\text {bio }}+0,117 * E M S_{\text {altr }}
\end{aligned}
$$

A regressziós egyenletek alapján - visszatérve a kiinduló modellem értelmezési keretéhez - a környezettudatos viselkedést a személyes norma, a környezeti attitüd, a környezeti aggodalom és a környezeti identitás 23,9\%-ban magyarázza, 76,1\%-ot a modellen kívül levő, nem specifikált változók hatása ad ki. A regressziós súlyokat a 17. ábra mutatja be. 


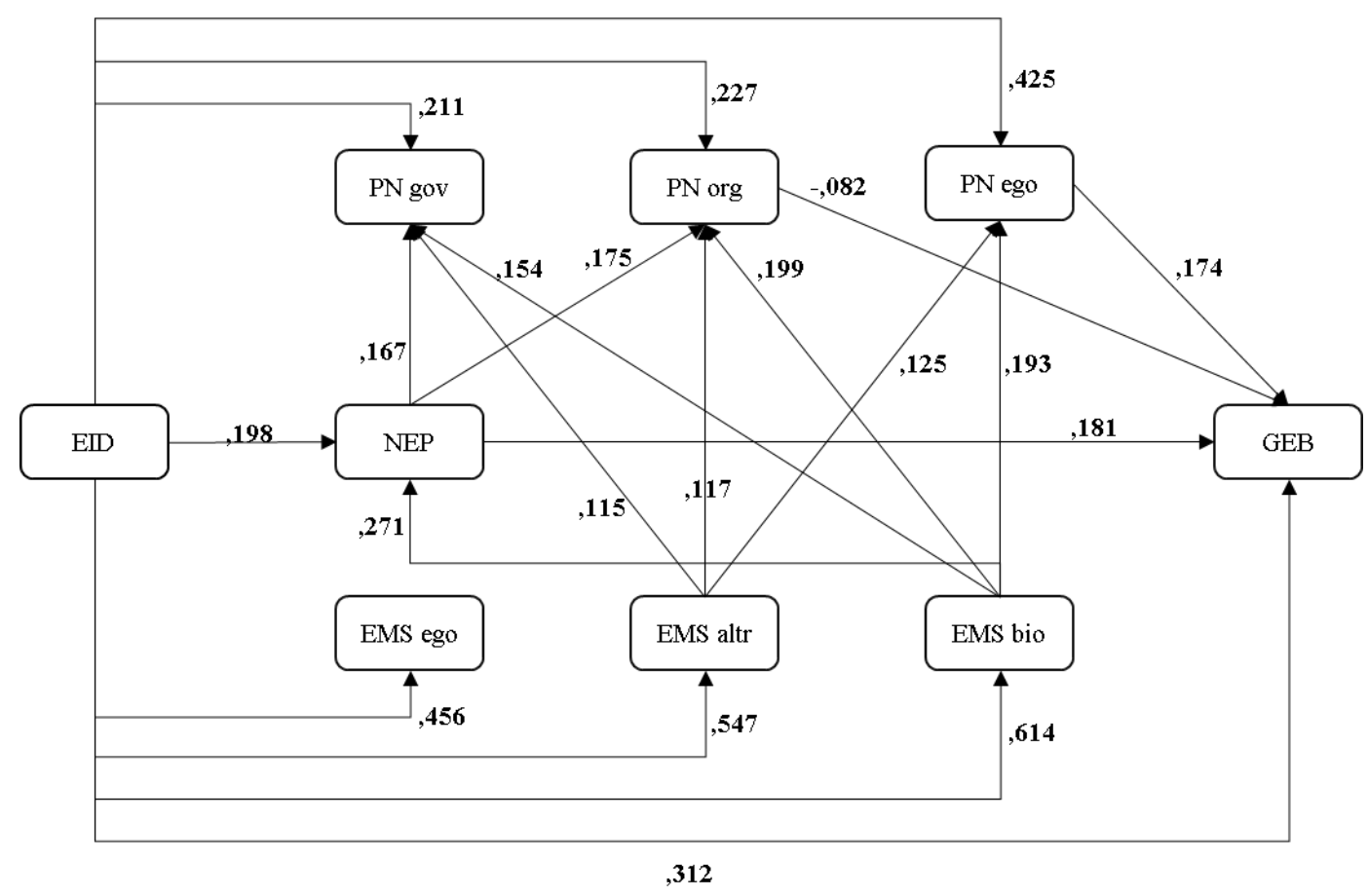

17. ábra: A környezettudatos viselkedés és a környezeti identitás összefüggésének útmodellje Forrás: saját szerkesztés

A modellből látható, hogy a vizsgált pszichográfiai tényezők közül a környezeti identitás hatása a legerősebb a környezetbarát viselkedésre. A környezeti identitás közvetlen hatása 0,312-es regressziós bétával rendelkezik. Emellett a környezeti identitás hatása endogén változókon keresztül is érvényesül, amelyek a közvetett hatást jelenítik meg. A modellben három darab kétszeresen összetett út, hat darab háromszorosan összetett út, és egy négyszeresen összetett út szerepel, a környezeti identitástól a környezetbarát viselkedésig

1. a NEP-en keresztül az út erössége: $0,198 * 0,181=0,036$

2. a személyes norma egyéni felelősségre vonatkozó alskáláján keresztül az út erössége: $0,425^{*} 0,174=0,074$

3. a személyes norma vállalati felelösségre vonatkozó alskáláján keresztül az út erőssége: $0,227 *-0,082=-0,018$

4. a bioszférikus aggodalmon és a NEP-en keresztül az út erőssége: $0,614 * 0,271 * 0,181=0,030$

5. a bioszférikus aggodalmon és a személyes norma vállalati felelösségre vonatkozó alskáláján keresztül az út erőssége: $0,614 * 0,199 *-0,082=-0,010$

6. a bioszférikus aggodalmon és a személyes norma egyéni felelősségre vonatkozó alskáláján keresztül az út erőssége: $0,614 * 0,193 * 0,174=0,021$ 
7. a bioszférikus aggodalmon a NEP-en és a személyes norma vállalati felelősségre vonatkozó alskáláján keresztül az út erőssége: $0,614 * 0,271 * 0,175 *-0,082=-0,002$

8. az altruista aggodalmon és a személyes norma vállalati felelősségre vonatkozó alskáláján keresztül az út erőssége: $0,547 * 0,117^{*}-0,082=-0,005$

9. az altruista aggodalmon és a személyes norma egyéni felelősségre vonatkozó alskáláján keresztül az út erőssége: $0,547 * 0,125^{*} 0,174=0,012$

10. a NEP-en és a személyes norma vállalati felelősségre vonatkozó alskáláján keresztül az út erőssége: $0,198 * 0,175 *-0,082=-0,003$

A teljes közvetett hatás így 0,133 erősségü, amely kiegészítve a közvetlen hatással adja a környezeti identitás teljes hatását a környezetbarát tevékenység végzésére, amely összesen 0,446. A környezeti identitás esetében tehát a környezettudatos tevékenységre gyakorolt közvetlen hatás a kiemelkedő. A vizsgált belső tényezők közvetlen hatása jóval elmarad a környezeti identitás hatásától.

\subsubsection{KUTATÁSI EREDMÉNYEK ÖSSZEGZÉSE}

A vizsgált útmodell a környezetbarát viselkedésre hatással lévő pszichográfiai tényezőknek egy szűk körét vizsgálta, kiemelt fókuszban a környezeti identitás hatásának értelmezése volt. A modell 24\%-os magyarázóerővel rendelkezik, a környezeti identitás teljes hatása pedig 0,446. Összességében megállapíthatjuk, hogy a környezeti identitás vizsgálata a környezetbarát viselkedés alakulása során indokolt. A modell értelmezésével választ kapunk a hipotézis tesztekre is, amelyeket a 26. táblázat foglal össze.

A környezeti identitásnak közepesen erős pozitív hatása figyelhető meg mind a környezetbarát tevékenységre, mind a vizsgált pszichográfiai tényezőkre.

A legerősebb kapcsolat a belső tényezők közül a környezeti aggodalommal, azon belül is a $\mathrm{H} 4 \mathrm{~b}$ hipotézisnek megfelelően a bioszférikus aggodalommal van. Amennyiben közel érezzük magunkhoz a természetet, az épsége is fontosabbá válik, és jobban aggódunk érte (Mayer és Frantz, 2004). A környezeti identitás a környezeti attitüddel mutatja a leggyengébb pozitív kapcsolatot $(\beta=0,198)$, amely véleményem szerint a NEP skála felépítésének két jellemzőjén alapul. Egyrészt a NEP egyik erős faktora minden kutatásban a technológiai fejlődéssel szembeni szkepticizmus, amely nem 
feltétlenül jár együtt, vagy mondd ellent a környezeti identitás erősségének. Sokat kutatott környezetbarát szegmens például a LOHAS, akiknek a környezeti innovációk korai adaptálása az egyik kiemelt jellemzője. Az NMI (Natural Marketing Institute) 2009-es USA-ban folytatott kutatása a zöld fogyasztók öt csoportját különíti el, ezek a LOHAS, a Naturalisták, a Sodródók, a Konvencionisták és a Közömbösek (Ottman, 2011). Az egyes szegmensek közül a leginkább környezettudatos csoportot a LOHAS (Lifestyle of Health and Sustainability) képviseli. Ahogyan az elnevezésük is utal rá, a szegmens jelentős összefüggést tulajdonít a fenntartható életmód, ezáltal a természeti erőforrások megőrzése és az egyének egészségi állapota között. Ennek megfelelően olyan termékeket vásárol, amelyek az életminőség egyéni és globális javulását egyaránt elősegítik. A csoport tagjai jellemzően házas, képzett, középkorú nők, átlagnál magasabb jövedelmi helyzettel. Otthonukban, közösségeikben aktív részvevők, akik tudatos vásárlásaikon túl aktívan támogatják a témával kapcsolatos civil és politikai kezdeményezéseket is.

\begin{tabular}{|c|c|}
\hline Hipotézis & Elfogadás \\
\hline $\begin{array}{l}\text { H1: A környezeti identitás pozitívan hat a környezetbarát } \\
\text { magatartásra. Azaz minél erősebb környezeti identitással rendelkezik } \\
\text { az egyén, annál több környezetbarát viselkedést végez. }\end{array}$ & Igazolt \\
\hline $\begin{array}{l}\text { H4a: A környezeti identitásnak pozitív hatása van a környezeti } \\
\text { aggodalomra. }\end{array}$ & Igazolt \\
\hline $\begin{array}{l}\text { H4b: A környezeti identitásnak a bioszférikus aggodalomra van a } \\
\text { legerösebb hatása az egoista és az altruista aggodalommal összevetve. } \\
\text { Azaz az erösebb környezeti identitással rendelkezö egyénekre a } \\
\text { bioszférikus aggodalom a jellemzö, míg az alacsonyabb környezeti } \\
\text { identitás értékkel rendelkező egyénekre az egoista aggodalom } \\
\text { jellemző. }\end{array}$ & Igazolt \\
\hline $\begin{array}{l}\text { H4c: A környezeti aggodalomnak pozitív hatása van a } \\
\text { környezettudatos viselkedésre. }\end{array}$ & $\begin{array}{l}\text { Nem } \\
\text { igazolt }\end{array}$ \\
\hline $\begin{array}{l}\text { H5a: A környezeti identitásnak pozitív hatása van a környezeti } \\
\text { attitüdre. }\end{array}$ & Igazolt \\
\hline $\begin{array}{l}\text { H5b: A környezeti attitüdnek pozitív hatása van a környezettudatos } \\
\text { viselkedésre. }\end{array}$ & Igazolt \\
\hline $\begin{array}{l}\text { H6a: A környezeti identitásnak pozitív hatása van a személyes } \\
\text { normára. }\end{array}$ & Igazolt \\
\hline $\begin{array}{l}\text { H6b: A személyes norma pozitívan hat a környezettudatos } \\
\text { viselkedésre. }\end{array}$ & $\begin{array}{l}\text { Részben } \\
\text { igazolt }\end{array}$ \\
\hline
\end{tabular}

26. táblázat: Regressziós útmodellhez kötődő hipotézis teszt eredmények Forrás: saját elemzés 
Másodsorban a NEP általános megfogalmazásai lehetőséget adnak a távolításra és a hárításra.

Ugyanennek a problémahárításnak az ellenpontja állhat a környezeti identitásnak a személyes normával való erősebb pozitív kapcsolata mögött is. A környezeti identitásnak láthatóan erős hatása van az egyéni felelősségérzet erősségére. A környezeti identitás erősödésével szó szerint személyessé válik a környezetbarát tevékenység, amely aktívabb cselekvésekre is sarkallhat. A modell azt is mutatja, hogy a felelősség áthárításának a lehetősége, mások, például a szennyező vállalatok „hibáztatása” negatív hatással van a cselekvések megvalósulására.

Jelen modellben a vállalatok felelősségét tükröző személyes norma enyhe negatív hatással van a környezetbarát tevékenységek végzésére. Emiatt a H6b hipotézisünket csak részben tekintjük elfogadottnak, még úgy is, hogy a környezeti identitás közvetlen hatása a személyes felelősséget jelképező személyes norma esetében a legnagyobb. 


\section{EREDMÉNYEK ÉRTÉKELÉSE, KÖVETKEZTETÉSEK}

Disszertáció kutatásom abból az alapfeltevésből indult ki, hogy a környezettudatos viselkedés kialakulásának korlátai - legyen az külső (pl. infrastrukturális korlátok, alulinformáltság) vagy belső (pl. kognitív torzítások, bizalmatlanság, alacsony észlelet fogyasztói hatékonyság) akadályozó tényező (Hofmeister-Tóth és tsai., 2011) csökkenthetőek, és a környezetbarát tevékenységek iránti elköteleződés növelhető a környezeti identitás kialakításával. A környezeti identitás azáltal erősíti az elköteleződést, hogy az erős környezeti identitással rendelkező egyén a természetet az én-identitásába is beépíti. Mindez lehetővé teszi, hogy a természet védelme ugyanolyan fontossá váljon, mint önmaga védelme.

Az elméleti összefoglalás alapján a környezeti identitás mérésének eltérő lehetőségeit vizsgáltam az előtanulmányok során, majd a Clayton-féle Környezeti Identitás skála (2003) alkalmazásával készült a záró kvantitatív kutatás. A kutatás célja a környezeti identitás környezetbarát viselkedésekre gyakorolt hatásának a vizsgálata volt, amelyet Stern (1999) Érték-Hiedelem-Norma modelljén alapuló elméleti modellben vizsgáltam.

Az empirikus kutatásnak azzal a kutatási kérdéssel indultam, hogy megvizsgáljam a környezeti identitás és a környezetbarát viselkedés közötti kapcsolatot. Alapfeltevésem szerint a környezeti identitásnak erős hatása van a környezetbarát cselekvésekre, de feltételeztem, hogy további pszichográfiai tényezők mediáló hatásán keresztül is megjelenik. Így a környezeti identitást modellbe építve vizsgáltam. Az empirikus kutatás két szakaszra bontható, feltáró kvalitatív kutatásra és az összefüggések bizonyítása érdekében kvantitatív kutatásra. Az eltérő szakaszokhoz alkérdésekre bontottam a kutatási kérdést:

1. Melyek a környezeti identitás mérésének lehetséges módszerei?

a. Vizsgálata az előtanulmányok során történt, kvalitatív és kvantitatív valamint indirekt és direkt mérési módszerek alkalmazásával.

2. Milyen tényezők vannak hatással a környezeti identitás erősségére?

a. Vizsgálata lineáris regresszió segítségével történt, a második kvantitatív kutatás során. 
3. Milyen irányú és erősségű a környezeti identitás hatása a környezetbarát viselkedésre? Van-e közvetlen hatása a környezeti identitásnak, és ha igen, mely pszichográfiai tényezők mediáló hatását kell figyelembe venni?

a. Vizsgálata regressziós útmodell segítségével történt, a második kvantitatív kutatás során.

\subsection{EREDMÉNYEK ÖSSZEFOGLALÁSA}

Az egyes kutatási fázisok eredményei egymásra épültek, ezáltal próbáltam részletesen és strukturáltan körbejárni a környezeti identitás mérésének és hatásainak a kérdéseit. Feltáró kvalitatív kutatás volt a kiindulás, majd a kvantitatív elemzések során teszteltem a hipotéziseimet.

\section{Kvalitatív kutatás - elötanulmány}

A kutatás célja a természetről alkotott kép megismerése és értelmezése volt. A hallgatói élményeken keresztül feltártam a természethez kötődő elsődleges pozitív és negatív tapasztalatokat és élményeket. A kutatás föbb következtetései:

- A természet alatt több jelenséget értelmezhetünk, amely jelentős mértékben függ a pozitív vagy negatív érzelmi töltettől. Negatív jelenségként leggyakrabban az időjárás merült fel, míg a pozitív természeti élményben az erdő/kirándulások, valamint a víz jelent meg.

- A kisgyermekkori (általános iskola) élmények nagyobb gyakorisággal jelentek meg, mint az aktuális életesemények.

- A szülök esetében a példamutatást, a közös tevékenységek fontosságát hangsúlyozták az esszék, míg a kortársak esetében a közös élmények, kikapcsolódás volt a hangsúlyosabb szempont a társas helyzet bemutatása során.

- A környezeti identitás 5 dimenziója - azonosulás a természettel, pozitív élmények a természetben, ideológiai támogatás, életrajzi elemek és a vonás kiemelkedősége - amelyet Clayton (2003) javasol a koncepció értelmezésére, eltérő hangsúllyal, de megjelent az esszékben.

Összefoglalva a kutatás a természet széles értelmezési koncepcióját igazolta, és a természethez való kötődés, a természethez való érzelmi viszonyulás narratíváiban megtalálhatóak voltak a környezeti identitás értelmezésében alkalmazott dimenziók, 
amely a környezeti identitás koncepciójának a relevanciáját és megfelelő megközelítését bizonyította. Erre az eredményre alapozva készítettem el a következő előtanulmányt, amely már a környezeti identitás koncepciójának konkrét mérési lehetőségeire fókuszált.

\section{Kvantitatív kutatás - elötanulmány}

A kutatás célja a természettel való kapcsolat vizsgálatára kifejlesztett skálák tesztelése volt a megfelelő mérőeszköz kiválasztása érdekében.

- A vizsgált skálák [Schultz (2001) Inclusion of nature in the self (INS) skála, Nisbet - Zelenski - Murphy (2009) Nature Relatedness (NR) skála, Clayton (2003) Environmental Identity (EID), rövid változat] megbízhatóságának és érvényességének vizsgálata a Clayton-féle Környezeti Identitás skála alkalmazását támogatta.

- Az EID skála megfelelő megbízhatóságot mutatott, a feltáró főkomponens elemzés az elvárásoknak megfelelően 1 faktort eredményezett, amely 47\%-ot magyaráz a varianciából.

A kutatás elősegítette a Clayton-féle Környezeti Identitás skála kiválasztását a második, modellalkotásra alkalmas kvantitatív kutatáshoz. Az implicit mérés alkalmazhatóságára vonatkozóan ugyanakkor pontosabb kutatásra hívta fel a figyelmet, amely alapján előkészítettem az Implicit Asszociációs Teszt alkalmazásával végzett kutatásomat.

\section{Implicit Asszociációs Teszt}

A kutatás célja ebben a szakaszban az egyén és a természet kapcsolatának mérési kérdésének mélyebb vizsgálata volt. Dunlap és munkatársai (2000) értelmezésében az egyén környezethez való kötődése nem tudatos élmény, nem gondolunk rá rendszeresen. Emiatt az implicit vizsgálatok alkalmazását javasolják, amelyet Schultz és munkatársai (2004) munkája alapján az Implicit Asszociációs Teszt módszer alkalmazásával végeztem.

- A természet és az egyén kapcsolatának indirekt vizsgálata során a természeti környezet és az épített környezet között hasonló preferenciát tapasztaltam a válaszadóknál. Nemzetközi összehasonlításban az eddigi tapasztalatokhoz képest ez gyengébb természeti kötődést mutat.

- Az implicit mérés eredménye és a környezetbarát cselekvés mértéke között nem találtam kapcsolatot. 
- A direkt mérések esetében, egyaránt közepesen erős pozitív kapcsolatot találtam a környezeti attitüd és a környezetbarát viselkedések, valamint a környezeti identitás és a környezetbarát viselkedések között.

A kutatás az explicit mérések alkalmazhatóságát igazolta, amely alapján kialakítottam a környezeti identitás és a környezettudatos viselkedés vizsgálatára alkalmas kvantitatív kutatási koncepciómat.

\section{Kvantitatív kutatás, Regressziós útmodell}

A kutatás célja a környezeti identitás meghatározó tényezőinek a vizsgálata, valamint a környezeti identitás környezetbarát viselkedésre gyakorolt hatásának feltárása volt. Az elemzési modellbe további pszichográfiai tényezők is bevonásra kerültek, teszteltem a személyes norma, a környezeti attitüd és a környezeti aggodalom mediáló hatását.

- A Clayton-féle környezeti identitás skála megfelelő megbízhatósággal rendelkezik (Cronbach Alfa és Split-half módszer alapján). A skála felépítését konfirmatív faktorelemzéssel vizsgáltuk, amely igazolta az egy dimenziót, azonban az illeszkedési mutatók közül az AVE mutató enyhén elmarad az elvárttól (AVE=0,47), illetve az RMSEA mutató meghaladja a 0,05-öt (0,085). Az eredmények azt bizonyítják, hogy a skála alapvetően jól felépített, de további finomítások szükségesek.

- A környezeti identitásra a demográfiai változók közül a nemnek, a kornak a családi állapotnak és a háztartás méretének van szignifikáns hatása. A nők és az idősebbek rendelkeznek erősebb környezeti identitással. Az egyedülállók szignifikánsan gyengébb környezeti identitást mutatnak, amely a háztartás méretében is megmutatkozik (legmagasabb átlaggal a 2 fős háztartások rendelkeznek).

- A környezeti identitásra az értékek közül az Alkotás érzése, az Önmegvalósítás és a Biztonság van szignifikáns hatással.

- A környezetbarát tevékenységet 24\%-ban magyarázza a környezeti identitásra, a személyes normára, a környezeti attitüdre és a környezeti aggodalomra épülő modell.

- A környezeti identitás és a környezetbarát tevékenység között pozitív kapcsolat áll fenn, a környezeti identitás teljes hatása 0,446-es regressziós együtthatóval rendelkezik.

- Pozitív közvetlen hatása a környezetbarát cselekvésre a környezeti identitásnak, a környezeti attitűdnek és a személyes felelősségre vonatkozó személyes normának van. 
- Gyenge negatív hatása van a vállalatok felelősségére vonatkozó személyes normának, felhívva ezzel a figyelmet a felelősség hárítás negatív hatására a környezetbarát aktivitásra.

A kutatási eredmények alapján összefoglalóan megállapítható, hogy a környezeti identitásnak közepesen erős pozitív hatása van a környezetbarát tevékenységre. Érdemes azt is kiemelni, hogy a vizsgált pszichográfiai tényezőkhöz képest a legjelentősebb hatással rendelkezik a viselkedés kialakulására. Ezek az eredmények egybecsengnek azokkal a kutatásokkal, amelyek a társas identitást valamilyen formában beépítették a környezetbarát viselkedés vizsgálatába (Davis és tsai., 2011; Dono és tsai., 2010; Hinds és Sparks, 2008), és szintén szignifikáns hatást mutattak ki. Disszertációm modellje kiemeli a környezeti identitás szerepét, ezzel fókuszba helyezve a környezetvédelmet támogató társadalmi marketing kampányok számára.

Jelen kutatásban a környezeti attitüd hatását két koncepció keretében vizsgáltuk. A környezeti világnézet esetében szintén pozitív, de közepesnél gyengébb hatást találtunk. Az Új Környezeti Paradigma skála (NEP) a hazai mintán végzett faktorelemzés alapján 3 fő dimenziót vizsgál (részletesen lásd: (Hofmeister-Tóth és tsai., 2012b)), az egyén felsőbbrendüségében való hitet, a környezeti innovációkkal szembeni szkeptikusságot és a környezeti krízistől való aggodalmat. Ezek a koncepciók általános megközelítéssel rendelkeznek, így az erős közvetlen kapcsolat nem is elvárható a konkrét környezettudatos viselkedés mérésekkel (Ajzen és Fishbein, 1977). A környezeti aggodalomnak nincs közvetlen hatása a környezetbarát viselkedésre, a környezeti világnézeten keresztül hat csupán. Így azonban a környezeti identitás nem csak közvetlenül, de mint a bioszférikus környezeti aggodalom erős meghatározó tényezője közvetetten is hatással van a világnézetre. Kutatási hipotéziseimben a környezeti attitűd méréseket mint mediátor tényezőket vettem figyelembe, amelyet az empirikus kutatásom igazolt. A környezeti identitás mindkét koncepcióra hatással van. Azt is lényeges kiemelni, hogy a környezeti identitás és a környezeti aggodalom között általam feltételezett szorosabb kapcsolatot is igazolta a modell. Ez összhangban van Schultz elméletével (2000), miszerint ha az egyén a természetet az identitása részének tekinti, akkor az egyén bioszférikus aggodalma erősebb lesz, mint az altruista vagy az egoista aggodalma. 
Az eredmények gyakorlati hasznosíthatósága szempontjából a személyes norma értelmezésére kell még kitérnünk. A környezeti identitás pozitív hatása általánosan megfigyelhető a személyes norma minden alskálája esetében, tehát a környezeti identitásnak szerepe van abban is, hogy az egyén mennyire fogadja el a személyes felelősségét, illetve milyen mértékben tulajdonít felelősséget a kormányzatnak és a vállalatoknak. A környezeti identitásnak a legerősebb hatása az egyéni felelősség normája esetében volt megfigyelhető és a normának pozitív közvetlen hatása van a környezetbarát viselkedésre is. Ez a kapcsolat véleményem szerint azt tükrözi, hogy az erősebb környezeti identitással rendelkező egyén - azon keresztül, hogy identitásának részeként tekint a természetre - könnyebben elfogadja a saját felelősségét, mert tudja, hogy ha a normát megszegi az a számára értékes dolgokra (azaz a természetre) lesz negatív hatással (Stern, 2005). A belsővé tett és aktivált személyes norma hatására az egyén a saját tetteinek a következményeit is figyelembe veszi, és aktívabban végez környezetbarát tevékenységeket (Babcock, 2009). A fenntartható fejlödés kialakításához természetesen elengedhetetlen a többi érintett, mint a kormányzat és a vállalatok felelősségének felismerése. Az egyének, fogyasztók elvárása a kormányzattal és a vállalatokkal szemben szükséges, viselkedésükkel nyomást gyakorolhatnak a kormányzati szabályozásra és a vállalatok tevékenységére is. Az eredmények azonban azt mutatják, hogy a vállalatok felelősségének normaként való belsővé tétele enyhe negatív hatással van a környezetbarát viselkedésre, ami véleményem szerint a felelősség hárításának lehetőségével magyarázható.

Mindezek alapján a 27. táblázatban megadom az eredmények, a hipotézisek összefoglaló értékelő táblázatát és az eredmények alapján megfogalmazott hat végső tézisemet.

\section{Végső tézisek}

1. A környezeti identitásnak közepesen erős pozitív hatása van a környezettudatos viselkedésre közvetlenül, és a mediáló változókon keresztül közvetetten is.

2. A demográfiai tényezők közül szignifikáns hatása a nemnek, a kornak, a családi állapotnak és a háztartás méretének van a környezeti identitás mértékére.

3. A környezeti identitásra az értékek közül az Alkotás érzése, az Önmegvalósítás és a Biztonság van szignifikáns hatással. 
4. A környezeti identitásnak az aggodalom minden típusára pozitív hatása van. A legerősebb kapcsolat a bioszférikus aggodalommal összefüggésben jelenik meg.

5. A környezeti attitűd mediáló szerepet tölt be a környezeti identitás és a környezettudatos viselkedés kapcsolatában, pozitív hatással.

6. A környezeti identitásnak általánosan pozitív hatása van a személyes normára. A személyes norma esetében az egyéni felelősségérzésnek pozitív, a vállalatoknak tulajdonított felelősségnek ugyanakkor negatív hatása van a környezettudatos viselkedés mértékére.

\begin{tabular}{|c|c|c|}
\hline Hipotézis & Elfogadás & Végső tézis \\
\hline $\begin{array}{l}\text { Elözetes feltevés az IAT kutatáshoz: } \\
\text { Az implicit környezeti identitás } \\
\text { pozitív hatása a környezettudatos } \\
\text { fogyasztói viselkedésre erősebb, } \\
\text { mint az explicit mérésủ identitásnak. }\end{array}$ & $\begin{array}{l}\text { Nem igazolt, } \\
\text { Nincs } \\
\text { kimutatható } \\
\text { hatás }\end{array}$ & \\
\hline $\begin{array}{l}\text { H1: A környezeti identitás pozitívan } \\
\text { hat a környezetbarát magatartásra. } \\
\text { Azaz minél erösebb környezeti } \\
\text { identitással rendelkezik az egyén, } \\
\text { annál több környezetbarát } \\
\text { viselkedést végez. }\end{array}$ & Igazolt & $\begin{array}{l}\text { 1. A környezeti identitásnak közepesen } \\
\text { erös pozitív hatása van a környezettudatos } \\
\text { viselkedésre közvetlenül, és a mediáló } \\
\text { változókon keresztül közvetetten is. }\end{array}$ \\
\hline $\begin{array}{l}\text { H2a: Az iskolai végzettség pozitív } \\
\text { hatással van a környezeti identitásra, } \\
\text { azaz minél magasabb az egyén } \\
\text { iskolai végzettsége, annál erösebb } \\
\text { környezeti identitással rendelkezik. }\end{array}$ & $\begin{array}{l}\text { Nem igazolt, } \\
\text { Nincs } \\
\text { kimutatható } \\
\text { hatás }\end{array}$ & \multirow{4}{*}{$\begin{array}{l}\text { 2. A demográfiai tényezők közül } \\
\text { szignifikáns hatása a nemnek, a kornak, a } \\
\text { családi állapotnak és a háztartás méretének } \\
\text { van a környezeti identitás mértékére. }\end{array}$} \\
\hline $\begin{array}{l}\text { H2b: A nök erösebb környezeti } \\
\text { identitással rendelkeznek. }\end{array}$ & Igazolt & \\
\hline $\begin{array}{l}\text { H2c: A jövedelem pozitív hatással } \\
\text { van a környezeti identitásra. Azaz } \\
\text { minél magasabb az egyén } \\
\text { jövedelme, annál erösebb } \\
\text { környezeti identitással rendelkezik. }\end{array}$ & $\begin{array}{l}\text { Nem igazolt, } \\
\text { Nincs } \\
\text { kimutatható } \\
\text { hatás }\end{array}$ & \\
\hline 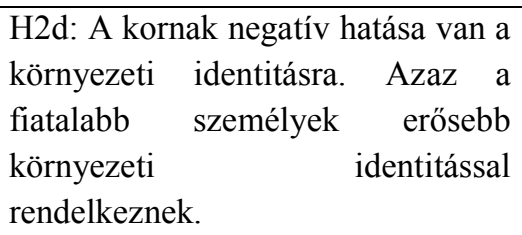 & $\begin{array}{l}\text { Nem igazolt, } \\
\text { pozitív hatása } \\
\text { van }\end{array}$ & \\
\hline $\begin{array}{l}\text { H3: A környezeti identitásra a belső } \\
\text { értékeknek erősebb hatása van, mint } \\
\text { a külső értékeknek. }\end{array}$ & $\begin{array}{c}\text { Részben } \\
\text { igazolt }\end{array}$ & $\begin{array}{l}\text { 3. A környezeti identitásra az értékek közül } \\
\text { az Alkotás érzése, az Önmegvalósítás és a } \\
\text { Biztonság van szignifikáns hatással. }\end{array}$ \\
\hline
\end{tabular}




\begin{tabular}{|c|c|c|}
\hline $\begin{array}{l}\text { H4a: A környezeti identitásnak } \\
\text { pozitív hatása van a környezeti } \\
\text { aggodalomra. }\end{array}$ & Igazolt & \multirow{3}{*}{$\begin{array}{c}\text { 4. A környezeti identitásnak az aggodalom } \\
\text { minden típusára pozitív hatása van. A } \\
\text { legerősebb kapcsolat a bioszférikus } \\
\text { aggodalommal összefüggésben jelenik } \\
\text { meg. }\end{array}$} \\
\hline $\begin{array}{l}\text { H4b: A környezeti identitásnak a } \\
\text { bioszférikus aggodalomra van a } \\
\text { legerösebb hatása az egoista és az } \\
\text { altruista aggodalommal összevetve. } \\
\text { Azaz az erősebb környezeti } \\
\text { identitással rendelkező egyénekre a } \\
\text { bioszférikus aggodalom a jellemző, } \\
\text { míg az alacsonyabb környezeti } \\
\text { identitás értékkel rendelkező } \\
\text { egyénekre az egoista aggodalom } \\
\text { jellemző. }\end{array}$ & Igazolt & \\
\hline $\begin{array}{l}\text { H4c: A környezeti aggodalomnak } \\
\text { pozitív hatása van a } \\
\text { környezettudatos viselkedésre. }\end{array}$ & $\begin{array}{l}\text { Nem igazolt, } \\
\text { Nincs } \\
\text { kimutatható } \\
\text { hatás }\end{array}$ & \\
\hline $\begin{array}{l}\text { H5a: A környezeti identitásnak } \\
\text { pozitív hatása van a környezeti } \\
\text { attitüdre. }\end{array}$ & Igazolt & \multirow{2}{*}{$\begin{array}{l}\text { 5. A környezeti attitüd mediáló szerepet } \\
\text { tölt be a környezeti identitás és a } \\
\text { környezettudatos viselkedés kapcsolatában, } \\
\text { pozitív hatással. }\end{array}$} \\
\hline $\begin{array}{l}\text { H5b: A környezeti attitüdnek } \\
\text { pozitív } \\
\text { környezettudatos viselkedésre. }\end{array}$ & Igazolt & \\
\hline $\begin{array}{l}\text { H6a: A környezeti identitásnak } \\
\text { pozitív hatása van a személyes } \\
\text { normára. }\end{array}$ & Igazolt & \multirow{2}{*}{$\begin{array}{l}\text { 6. A környezeti identitásnak általánosan } \\
\text { pozitív hatása van a személyes normára. A } \\
\text { személyes norma esetében az egyéni } \\
\text { felelősségérzésnek pozitív, a vállalatoknak } \\
\text { tulajdonított felelősségnek ugyanakkor } \\
\text { negatív hatása van a környezettudatos } \\
\text { viselkedés mértékére. }\end{array}$} \\
\hline $\begin{array}{l}\text { H6b: A személyes norma pozitívan } \\
\text { hat a környezettudatos viselkedésre. }\end{array}$ & $\begin{array}{l}\text { Részben } \\
\text { igazolt }\end{array}$ & \\
\hline
\end{tabular}

27. táblázat: Hipotézis teszt eredményeinek az összegzése

Forrás: saját elemzés

\subsection{A KÖRNYEZETI IDENTITÁS MÉRÉSÉRE VONATKOZÓ KÖVETKEZTETÉSEK}

A környezeti identitás koncepció mérési lehetőségeinek vizsgálata során két kérdésre kerestem választ. Első kérdés az explicit és az implicit mérések közötti különbség feltárására vonatkozott, a második kérdés pedig az explicit mérések közötti választásra és alkalmazásra.

Az implicit mérés esetében a természeti környezet és az épített környezet esetében majdnem azonos preferenciával rendelkeztek a válaszadók. Értelmezésben ez kissé alul maradt az explicit skálán mért környezeti identitás erősségéhez képest, az implicit mérés gyengébb kapcsolatot mutatott a természettel, mint az explicit mérés. Ez az eredmény alapvetően összhangban van az Implicit Asszociációs Teszt és az explicit 
mérések közti általános különbséggel (Perkins és tsai., 2008). Az explicit és az implicit mérések között jelen kutatásban nem volt mérhető szignifikáns kapcsolat, amely ellenben eltér a korábbi IAT-Nature tapasztalatoktól (Schultz és tsai., 2004; Schultz és Tabanico, 2007).

Eredményeimet, miszerint az explicit és implicit mérések között nincs kapcsolat, kétféleképpen lehet értelmezni. Egyrészröl jelentheti azt, hogy az indirekt (IATNature) illetve a direkt (EID skála) úton vizsgált koncepciók eltérnek egymástól, azaz nem ugyanazt a fogalmat mérik. A szakirodalom azonban az implicit és az explicit mérések körültekintő összehasonlítására hívja fel a figyelmet. Kutatási területtől függően (pl. elöítélet vagy sztereotípia) hiányozhat, vagy nagyon alacsony lehet a kapcsolat a mérési módszerek között, míg a társadalmilag nem vitás, nem érzékeny területek esetében erősebb összefüggések találhatóak. Fazio és Olson (2003) a MODE modell alkalmazását javasolja az értelmezéshez. A MODE (motivation and opportunity to deliberate) modell alapján a kapcsolatot a válasz megfontolásának lehetősége és a megfontolásra való motiváltság határozza meg. Erős kapcsolat várható, ha nincs lehetőség és/vagy szándék az explicit megkérdezés esetében a válasz átgondolására, míg ha az explicit válaszadáskor van alkalom és szándék a megfontolásra alacsony korreláció várható (Fazio és Olson, 2003). Jelen kutatásban a válaszadóknak volt lehetőségük az explicit válaszok átgondolására.

Az eredmények alapján disszertációmban az explicit mérésekre fókuszáltam, azonban nem vetem el az implicit mérési eszköz, az IAT alkalmazásának a lehetőségét. Jövőbeli kutatásként az implicit mérés alkalmazását továbbra is fontosnak tartom és egy megfelelően felépített kísérletben implicit viselkedésméréssel együttesen tervezem alkalmazni.

Az explicit mérések közül a Clayton-féle Környezeti Identitás skálát alkalmaztam a hazai környezetben. A bemutatott eredmények a skála alkalmazhatóságát támogatták. A skála 11 állításból áll, amelyek több területre vonatkoznak: megjelenik a vonás kiemelkedősége, az ideológia és a pozitív érzelmek is, valamint legnagyobb hangsúllyal a természettel való azonosulás kérdései. A 24 állításos skálához képest az életrajzi elemek vizsgálatát nem tartalmazza a szükített skála.

A skála megfelelő adaptálásának érdekében feltáró faktorelemzést is végeztem. Főkomponens analízis (PCA) segítségével is vizsgáltam a skála dimenzionalitását és 
megbízhatóságát (részletes táblázatokat lásd a mellékletben). A skála egy faktorba tömörült, a faktorelemzés eredménye megbízható ${ }^{32}$. A faktor a variancia 52,2\%-át magyarázza, amely a korábbi hallgatói mintán történt előmérésekhez képest magasabb érték. Az állítások kommunalitásait vizsgálva az első és a nyolcadik állítás ${ }^{33}$ nem éri el a szükséges 0,5-ös értéket. A faktor magyarázóereje növelhető az adott állítások eltávolításával (55,8\%). Az elemzés két állítás különállóságát mutatta és az állítások skálából való kivételét támogatja. A nyolcadik állítás:

„Inkább élnék egy szép kilátással rendelkezö kisebb szobában vagy házban, mint egy olyan szobában, vagy házban, amely nagyobb, de már épületekre néz."

Az állítás egy dupla állítás, amely azt várja a válaszadótól, hogy egyszerre kezelje a lakás méretének és az elhelyezkedésének esztétikai szempont kérdését. A válasz értékelése során tehát nem lehetünk biztosak abban, hogy a válaszadó melyik szempont alapján döntött. Ez következetlenné teheti az eredményeket. Emiatt az állítás láthatóan kilóg a többi közül. A jövőbeli alkalmazáshoz az állítás skálából való eltávolítását javaslom.

Az állítások darabszáma a rövidített skálában nem kiegyensúlyozott a dimenziók között. Az első állítás például egyedül méri a vonás kiemelkedőségének, a viselkedés megvalósulásának a dimenzióját:

„Sok idöt töltök természeti környezetben (erdö, hegyvidék, puszta, tópart, tengerpart).,

Az eltérő téma miatt az állítás szintén kilóg a többi közül, ezért meg kell fontolni az állítás eltávolítását a skálából. A viselkedés dimenzió jelentőségét figyelembe véve azonban a skála megbízhatósága és érvényessége azáltal is javítható lenne, ha további állításokat vonnánk be a viselkedés dimenzió értékelésére. Ez azért is lenne fontos, mert az eredmények azt mutatják, hogy még az a válaszadó is, aki a természethez közel érzi magát, gyakran alacsony értékelést adott erre az állításra. A természetben töltött idő folyamatosan csökken napjaink urbanizált, felgyorsult életmódot élő társadalmában. A viselkedés értékelésére érdemes lehet nem csupán a természetről

\footnotetext{
${ }^{32}$ A théta megbízhatósági együttható értéke 0,908 , amely alátámasztja a korábbi eredményeket a skála megfelelő megbízhatóságáról. A Bartlett-teszt eredménye $(\mathrm{p}<0,000)$ alapján a nullhipotézis elvethető, a KMO - teszt értéke 0,940, így a faktorelemzés eredménye elfogadható.

${ }^{33}$ Első állítás a természetben szerzett élményekre vonatkozik: Sok időt töltök természeti környezetben (erdö, hegyvidék, puszta, tópart, tengerpart).

Nyolcadik állítás az épített és a természeti környezetet veti össze: Inkább élnék egy szép kilátással rendelkező kisebb szobában vagy házban, mint egy olyan szobában, vagy házban, amely nagyobb, de már épületekre néz.
} 
szerzett direkt tapasztalatokat figyelembe venni, hanem az indirekt és a szimbolikus tapasztalatokat $^{34}$ is (Kellert, 2002).

A jövőbeli kutatások során a skála tesztelését a skála dimenzióinak a kiegyenlítése és a kilógó állítások elhagyása után tervezem folytatni.

\subsection{A KÖRNYEZETI IDENTITÁS VIZSGÁLATÁNAK ELMÉLETI ÉS GYAKORLATI JELENTŐSÉGE}

A marketingben a környezetvédelem területén az identitás koncepcióját a kutatások alapvetően termék, illetve vásárlási helyzet specifikus társas identitás formájában vizsgálták (például zöld fogyasztói identitás, lásd: Sparks és Shepherd, 1992; Whitmarsh és O'Neill, 2010). Kutatásom célja a identitás konkrét vásárlói helyzeten kívüli értelmezése, általánosabb szinten való vizsgálata volt annak érdekében, hogy a környezetbarát tevékenységek szélesebb köre váljon általa magyarázhatóvá. Ennek érdekében a kutatásom a környezeti identitás - a természetet, mint társas környezetet értelmező identitás - fogalmát járta körbe. A koncepció a környezeti pszichológia területén már megalapozott fogalom, a vizsgálatára azonban változó hangsúlyt fektettek a modellek. Disszertációm jelentősége, hogy bizonyítja a természethez való kapcsolat és a fogyasztói viselkedés közötti közvetlen és közvetett hatásainak a meglétét, s tényezőit, meghatározó összefüggéseit.

Kutatásom újszerüsége, hogy a környezeti identitást saját, előkutatásaimmal megalapozott modellbe helyezve vizsgáltam, amely Stern Érték-Norma-Hiedelem modell koncepcióján (1999) alapult. Ezáltal a környezeti identitás környezeti attitüdre, környezeti aggodalomra és a személyes normára gyakorolt hatását is figyelembe vettem. A feltárt eredmények a környezeti identitás hatásainak részletes elemzésével új összefüggéseket és kapcsolatokat tártak fel - melyeket a téziseimben foglaltam össze - erősítve a környezeti identitás előrejelző szerepét a környezetbarát fogyasztói

\footnotetext{
${ }^{34}$ Direkt tapasztalatnak tekintjük a természeti környezetben történő valós, spontán fizikai kontaktust, azaz ha a gyermek a kertben, az erdőben spontán aktivitás során tapasztalja meg a természetet. Indirekt tapasztalatnak tekintjük, ha van fizikai kontaktus a természettel, de az egy tervezett, irányított és ezáltal korlátozottabb formában valósul meg, például állatkertben, múzeumban vagy kiskerti virágültetés során. Szimbolikus tapasztalatnak pedig az tekinthető, amikor nincs fizikai kapcsolat a természettel, hanem a természeti jelenetek szimbolikus vagy akár realisztikus formában jelennek meg a gyermek számára. A modern társadalomban ennek a leggyakoribb közvetítő formája a tömegmédium, a televízió, könyvek és magazinok, amelyek természeti képeket sugároznak (Kellert, 2002).
} 
viselkedés meghatározásában. A modellbe bevont pszichográfiai változókkal megtettem a kiinduló lépést a környezeti identitás magyarországi vizsgálatában, a gyakorlati felhasználás adaptációjának előkészítésében. A környezeti identitás erős pozitív hatással van mind a környezettudatos viselkedésre, mind a további vizsgálatra bevont mediátor változókra, így az eredmények a koncepció további kutatási alkalmazását támogatják.

A kutatás gyakorlati jelentősége, hogy a környezetbarát tevékenységek kialakulására irányuló társadalmi marketing kampányok fókuszába új tényező, a környezeti identitás bevonását veti fel. A társadalmi marketing eszköztára alkalmas a viselkedésváltozás támogatására, azonban gyakran felmerül a probléma, hogy a társadalmi marketinggel foglalkozó szakemberekhez nem jut el a környezeti pszichológia és a fogyasztói magatartás kutatások által feltárt tudás (McKenzie-Mohr, 2000). Disszertációmmal célom a két terület közötti kommunikáció, tudásáramlás további elősegítése. A környezetbarát viselkedések kialakulását, támogatását célzó társadalmi marketing kampányok alapvetően két irányból közelítenek, egyrészt pozitív attitüd kialakításával illetve környezeti tudás biztosításával, másrészt a gazdasági motívumok hangsúlyozásával akarnak hatni a lakosságra. Ezek a koncepciók alapvetően a racionális egyénre építenek, aki gazdasági és egyéni érdekek mentén változtat a viselkedésén. Disszertációm eredményei azonban a szakirodalommal összhangban (Clayton, 2003, DeGroot és Steg, 2008, Schultz, 2000, Stern, 2005) azt hangsúlyozzák, hogy a környezetbarát viselkedések kialakulásához a bioszférikus értékorientáció és a természettel való szoros személyes kötődés biztosíthat alapot. Ennek érdekében a kampányoknak nem csak a környezetbarát tevékenységek akadályainak a leküzdésére kell fókuszálnia, hanem a környezeti identitás kialakítására, a természettel való szoros kapcsolat elősegítésére.

Az integrált marketing szemlélet mentén az érintettek széles köre bevonható a társadalmi marketing tevékenységekbe, a kormányzat a környezeti nevelésbe erősebb hangsúllyal kell, hogy beépítse a természetben szerezhető direkt tapasztalatokat is az indirekt és a szimbolikus tapasztalatok mellé. A civil szféra elősegítheti a környezeti személyes norma kialakulását és belsővé tételét, míg a vállalatok a környezeti identitás környezetbarát tevékenységekben való megjelenését segíthetik elő a fogyasztók választás irányításával. 


\subsection{KUTATÁS KORLÁTAI ÉS JÖVŐBENI KUTATÁSI LEHETÖSÉGEK}

A kutatási eredmények a megbízhatósági és érvényességi elemzéseknek megfeleltek. $\mathrm{Az}$ eredmények általánosíthatósága azonban korlátozottan lehetséges. $\mathrm{Az}$ előtanulmányok hallgatói mintán készültek, amely a körültekintő értékelést teszi szükségessé. A záró kvantitatív kutatásunk országos mintán készült, amely az eredmények stabilitását és elfogadását támogatja.

A kutatás korlátjának tekinthető a szűk elemzési modell alkalmazása, amely a személyes belső tényezőknek is csak egy-egy tényezőjét emeli ki. A környezeti identitás szerepének a további részletes elemzéséhez komplex modell kialakítása szükséges, amely a pszichográfiai tényezők szélesebb körével számol (lásd például Thøgersen Motiváció - Lehetőség - Képesség modelljét (Motivation - Opportunity Ability Model, 1995) és a fogyasztók külső lehetőségeit is figyelembe veszi.

A kvantitatív kutatás fókuszának szélesítése mellett a kísérleti módszertan alkalmazását is releváns továbblépési lehetőségnek tekintem. Ez lehetővé teszi az implicit mérés valós hatásának értékelését azáltal, hogy a környezetbarát tevékenységet is implicit méréssel vizsgálja.

A környezeti identitás gyakorlati alkalmazhatóságának biztosítása érdekében további kvalitatív kutatás megvalósítását tervezem, amely célja a környezeti identitás előzményeinek a részletes feltárása. A témában természetesen számos szakirodalmi forrás elérhető, a további kutatás jelentőségét azonban abban látom, hogy a hazai kulturális környezet eltéréseit kiemelje a nemzetközi mintával szemben, valamint hogy meghatározza azokat a beavatkozási pontokat, ahol a társadalmi marketing megjelenhet. 


\section{IRODALOMJEGYZÉK}

Achrol, R. S., és Kotler, P. (2012). Frontiers of the marketing paradigm in the third millennium. Journal of the Academy of Marketing Science, 40(1), 35-52. doi: 10.1007/s11747-011-0255-4

Ajzen, I. (1985). From intentions to actions: A theory of planned behavior Kuhl, J. és Beckman, J. (Eds.), Action control: From cognition to behavior (pp. 11-39). Heidelberg: Springer

Ajzen, I. (1988). Attitudes, personality, and behavior. Milton Keynes: Open University Press.

Ajzen, I. (1991). The theory of planned behavior. Organisational Behavior and Human Decision Processes, 50(2), 179-211. doi: 10.1016/07495978(91)90020-T

Ajzen, I. (2002). Perceived Behavioral Control, Self-Efficacy, Locus of Control, and the Theory of Planned Behavior. Journal of Applied Social Psychology, 32(4), 665 - 683. doi: 10.1111/j.1559-1816.2002.tb00236.x

Ajzen, I., és Fishbein, M. (1977). Attitude-behavior relations: A theoretical analysis and review of empirical research. Psychological Bulletin, 84(5), 888-918. doi: http://dx.doi.org/10.1037/0033-2909.84.5.888

Ajzen, I., és Fishbein, M. (1980). Understanding Attitudes and Predicting Social Behavior. New Jersey: Prentice Hall.

Allport, G. W. (1954). The historical background of modern social psychology Lindzey, G. (Ed.), A handbook of social psychology (pp. 798-844). Worchester, MA: Clark University Press

Anderson, W. T., és Cunningham, W. H. (1972). The Socially Conscious Consumer. The Journal of Marketing, 36(3), 23-31.

Andreasen, A. (2006). Social Marketing in the 21st Century. Thousand Oaks, California: Sage Publications.

Antil, J. H. (1978). The Construction and Validation of an Instrument to Measure Socially Responsible Consumer Behavior: A Study of the Socially Responsible Consumer. Doctoral dissertation, The Pennsylvania State University.

Armitage, C., és Conner, M. (2001). Efficacy of the Theory of Planned Behaviour: a Meta-analytic Review. British Journal of Social Psychology, 40, 471-499. doi: 10.1348/014466601164939

Aron, A., Aron, E. N., és Smollan, D. (1992). Inclusion of other in the self scale and the structure of interpersonal closeness. Journal of Personality and Social Psychology, 63, 596-612. doi: http://dx.doi.org/10.1037/0022-3514.63.4.596

Aron, A., Aron, E. N., Tudor, M., és Nelson, G. (1991). Close relationships as including other in the self. Journal of Personality and Social Psychology, 60, 241-253. doi: http://dx.doi.org/10.1037/0022-3514.60.2.241 
Aronson, E., és Cope, V. (1968). My enemy's enemy is my friend. Journal of Personality and Social Psychology, 8(1), 8-12. doi: http://dx.doi.org/10.1037/h0021234

Aronson, E., és O’Leary, M. (1982). The relative effectiveness of models and prompts on energy conservation: A field experiment in a shower room. Journal of Experimental Systems, 12, 219-224.

Babbie, E. (2001). A társadalomtudományi kutatás gyakorlata (6 ed.). Budapest: Balassi Kiadó.

Babcock, H. M. (2009). Assuming Personal Responsibility for Improving the Environment: Moving Toward a New Environmental Norm. Harvard Environmental Law Review, 33, 117-175.

Baddeley, A. (2003). Az emberi emlékezet. Budapest: Osiris Kiadó.

Bagozzi, R. P., és Schnedlitz, P. (1985). Social Contingencies in the Attitude Model: A Test of Certain Interaction Hypotheses. Social Psychology Quarterly, 48(4), 366-373.

Baldwin, J. M. (1897). Social and ethical interpretations in mental development. New York: Macmillan.

Bamberg, S. (2003). How does environmental concern influence specific environmentally related behaviors? A new answer to an old question. Journal of Environmental Psychology, 23, 21-32. doi: 10.1016/S0272-4944(02)000786

Bamberg, S., és Möser, G. (2007). Twenty years after Hines, Hungerford, and Tomera: A new meta-analysis of psycho-social determinants of pro-environmental behaviour. Journal of Environmental Psychology, 27(1), 14-25. doi: 10.1016/j.jenvp.2006.12.002

Banerjee, S., és McKeage, K. (1994). How green is my value: exploring the relationship between environmentalism and materialism Allen, C. T. és John, D. R. (Eds.), Advances in Consumer Research (Vol. 21, pp. pp. 147-152). Provo, UT: Association for Consumer Research

Bar-Anan, Y., és Nosek, B. A. (2014). A comparative investigation of seven implicit measures of social cognition. Behavior Research Methods, 46(3), 668-688. doi: $10.3758 / \mathrm{s} 13428-013-0410-6$

Bargh, J. A. (2006). What have we been priming all these years? On the development, mechanisms, and ecology of nonconscious social behavior? European Journal of Social Psychology, 36(2), 147-168. doi: 10.1002/ejsp.336

Bartels, J., és Hoogendam, K. (2011). The role of social identity and attitudes toward sustainability brands in buying behaviors for organic products. Journal of Brand Management, 18(9), 697-708. doi: 10.1057/bm.2011.3

Beatty, S. E., Kahle, L. R., Homer, P., és Misra, S. (1985). Alternative Measurement Approaches to Consumer Values: The List of Value Survey. Psychology \& Marketing, 2(3), 181-201. doi: 10.1002/mar.4220020305

Blumer, H. (1969). Symbolic interactionism: Perspective and method. Englewood Cliffs, NJ: Prentice-Hall. 
Bolton, L. E., és Reed, A. (2004). Sticky priors: The perseverance of identity effects on judgment. Journal of Marketing Research, 41(3), 397-411. doi: http://dx.doi.org/10.1509/jmkr.41.4.397.47019

Bordens, K. S., és Horowitz, I. A. (2008). Social Psychology. United States of America: Freeload Press.

Bragg, E. A. (1996). Towards Ecological Self: deep ecology meets constructionist selftheory. Journal of Environmental Psychology, 16(2), 93-108. doi: 10.1006/jevp.1996.0008

Brickman, P., és Horn, C. (1973). Balance theory and interpersonal coping in triads. Journal of Personality and Social Psychology, 26(3), 347-355. doi: $10.1037 / \mathrm{h} 0034444$

Brown, T. A. (2006). Confirmatory Factor Analysis for Applied Research (Vol. 6). New York: The Guilford Press.

Bruni, C. M., Chance, R. C., Schultz, P. W., és Nolan, J. M. (2012). Natural Connections: Bees Sting and Snakes Bite, But They Are Still Nature. Environment and Behavior, 44(2), 197-215. doi: 10.1177/0013916511402062

Bruni, C. M., és Schultz, P. W. (2010). Implicit beliefs about self and nature: Evidence from an IAT game. Journal of Environmental Psychology, 30(1), 95-102. doi: 10.1016/j.jenvp.2009.10.004

Brügger, A., Kaiser, F. G., és Roczen, N. (2011). One for All? Connectedness to Nature, Inclusion of Nature, Environmental Identity, and Implicit Association with Nature. European Psychologist, 16(4), 324-333. doi: http://dx.doi.org/10.1027/1016-9040/a000032

Buda, B. (1968). A szociálpszichológia és modern kutatási irányzatai. Szociológiai Közlemények, II, 15-46.

Bulla, M., Foltányi, Z., és Varga, É. (Eds.). (1993). Feladatok a XXI. századra - Az ENSz Környezet és Fejlödés Világkonferencia dokumentumai. Budapest: Föld Napja Alapítvány.

Burke, P. J. (2006). Identity change. Social Psychology Quarterly, 69(1), 81-96. doi: $10.1177 / 019027250606900106$

Burke, P. J., és Cast, A. D. (1997). Stability and change in the gender identities of newly married couples. Social Psychology Quarterly, 60, 277-290.

Burke, P. J., és Reitzes, D. C. (1991). An Identity Theory Approach to Commitment. Social Psychology Quarterly, 54(3), 239-251.

Burke, P. J., és Stets, J. E. (1999). Trust and Commitment through Self-Verification. Social Psychology Quarterly, 62(4), 347-366.

Burke, P. J., és Stets, J. E. (2009). Identity Theory. New York: Oxford University Press.

Byrne, B. M. (2010). Structural Equation Modeling with AMOS: Basic concepts, applications, and programming. London: Routledge.

Cantrill, J. G., és Senecah, S. L. (2001). Using the "sense of self-in-place" construct in the context of environmental policy-making and landscape planning. Environmental Science and Policy, 4(4-5), 185-203. doi: 10.1016/S14629011(01)00023-5 
Carson, R. (1962). Silent Spring. Boston: Houghton-Mifflin.

Carver, C. S., és Scheier, M. F. (2006). Személyiségpszichológia. Budapest: Osiris Kiadó.

Catton, W. R., Jr., , és Dunlap, R. E. (1980). A new ecological paradigm for postexuberant sociology American Behavioral Scientist, 24(15-47). doi: 10.1177/000276428002400103

Chattaraman, V., Lennon, S. J., és Rudd, N. A. (2010). Social Identity Salience: Effects on Identity-Based Brand Choices of Hispanic Consumers. Psychology \& Marketing, 27(3), 263-284. doi: 10.1002/mar.20331

Chawla, L. (1998). Significant life experiences revisited: A review of research on sources of environmental sensitivity. Journal of Environmental Education, 29(3), 11-22. doi: 10.1080/00958969809599114

Chawla, L. (1999). Life paths into effective environmental action. Journal of Environmental Education, 31(1), 15-26. doi: 10.1080/00958969909598628

Chawla, L. (2006). Research methods to investigate significant life experiences: review and recommendations. Environmental Education Research, 12(3), 359374. doi: 10.1080/13504620600942840

Cialdini, R. B., Demaine, L. J., Sagarin, B. J., Barrett, D. W., Rhoads, K., és Winter, P. L. (2006). Managing social norms for persuasive impact. Social Influence, 1(1), 3-15. doi: 10.1080/15534510500181459

Cialdini, R. B., Reno, R. R., és Kallgren, C. A. (1990). A focus theory of normative conduct: Recycling the concept of norms to reduce littering in public places. Journal of Personality and Social Psychology, 58(6), 1015-1026. doi: http://dx.doi.org/10.1037/0022-3514.58.6.1015

Clayton, S. (2003). Environmental Identity: A Conceptual and an Operational Definition Clayton, S. és Opotow, S. (Eds.), Identity and the Natural Environment: The Psychological Significance of Nature (pp. 45-67). Cambridge, Massachusetts: The MIT Press

Clayton, S., Fraser, J., és Burgess, C. (2011). The Role of Zoos in Fostering Environmental Identity. Ecopsychology, 3(2), 87-96. doi: $10.1089 /$ eco. 2010.0079

Clayton, S., és Opotow, S. (2003). Introduction: Identity and the Natural Environment Clayton, S. és Opotow, S. (Eds.), Identity and the Natural Environment: The Psychological Significance of Nature. Cambridge, Massachusetts: The MIT Press

Cohen, J. (1992). A power primer. Psychological Bulletin, 112, 155-159. doi: http://dx.doi.org/10.1037/0033-2909.112.1.155

Cook, A. J., Kerr, G. N., és Moore, K. (2002). Attitudes and intentions towards purchasing GM food. Journal of Economic Psychology, 23(5), 557-572. doi: 10.1016/S0167-4870(02)00117-4

Cooley, C. H. (1902). Human nature and the social order. New York: Scribner.

Cordano, M., Welcomer, S., Scherer, R. F., Pradenas, L., és Parada, V. (2011). A Cross-Cultural Assessment of Three Theories of Pro-Environmental Behavior: 
A Comparison Between Business Students of Chile and the United States. Environment \& Behavior, 43(5), 634-657. doi: 10.1177/0013916510378528

Cordano, M., Welcomer, S. A., és Scherer, R. F. (2003). An Analysis of the Predictive Validity of the New Ecological Paradigm Scale. The Journal of Environmental Education, 34(3), 22-28. doi: 10.1080/00958960309603490

Cronbach, L. J. (1951). Coefficient alpha and the internal structure of tests. Psychometrika, 16(3), 297-334. doi: 10.1007/BF02310555

Cronbach, L. J., és Meehl, P. E. (1968). Construct validity in psychological tests Feigl, H. és Scriven, M. (Eds.), The Foundations of Science and the Concepts of Psychology and Psychoanalysis (pp. 174-204). Minnesota: University of Minnesota

Csurgó, B. (2002). Környezet és társadalom, A Magyar Szociológiai Társaság 2001. évi közgyülése és konferenciája. Szociológiai Szemle, 1, 177-186.

Csutora, M. (2012). One More Awareness Gap? The Behaviour-Impact Gap Problem. Journal of Consumer Policy, 35, 145-163. doi: 10.1007/s10603-012-9187-8

Csutora, M., és Kerekes, S. (2004). A környezetbarát vállalatirányítás eszközei. Budapest: KJK-KERSZÖV.

Daly, H. (1992). Steady State Economics. London: Earthscan.

Daly, H. (1993). The perils of free trade. Scientific American, 269(5), 50-57. doi: 10.1038/scientificamerican1193-50

Davidson, D. J., és Freudenburg, W. R. (1996). Gender and Environmental Risk Concerns. Environment and Behavior, 28(3), 302-339. doi: $10.1177 / 0013916596283003$

Davies, J., Foxall, G. R., és Pallister, J. (2002). Beyond the Intention-Behaviour Mythology: An Integrated Model of Recycling. Marketing Theory, 2(1), 29113. doi: $10.1177 / 1470593102002001645$

Davis, J. J. (1995). The effects of message framing on response to environmental communications. Journalism and Mass Communication Quarterly, 72(2), 285-299. doi: 10.1177/107769909507200203

Davis, J. L., Green, J. D., és Reed, A. (2009). Interdependence with the environment: Commitment, interconnectedness, and environmental behavior. Journal of Environmental Psychology, 29(2), 173-180. doi: 10.1016/j.jenvp.2008.11.001

Davis, J. L., Le, B., és Coy, A. E. (2011). Building a Model of Commitment to the Natural Environment to Predict Ecological Behavior and Willingness to Sacrifice. Journal of Environmental Psychology, 31(3), 257-265. doi: 10.1016/j.jenvp.2011.01.004

De Groot, J. I. M., és Steg, L. (2008). Value orientations to explain environmental attitudes and beliefs: How to measure egoistic, altruistic and biospheric value orientations. Environment and Behavior, 40, 330-354. doi: $10.1177 / 0013916506297831$

De Young, R. (2000). Expanding and Evaluating Motives for Environmentally Responsible Behavior. Journal of Social Issues, 56(3), 509-526.

DeLamater, J. D., és Myers, D. J. (2011). Social psychology. Belmont, CA: Wadsworth Cengage Learning. 
Diamantopoulos, A., Schlegelmilch, B. B., Sinkovics, R. R., és Bohlen, G. M. (2003). Can socio-demographics still play a role in profiling green consumers? A review of the evidence and an empirical investigation. Journal of Business Research, 56(6), 465-480. doi: 10.1016/S0148-2963(01)00241-7

Dobson, A. (2007). Environmental Citizenship: Towards Sustainable Development. Sustainable Development, 15(5), 276-285. doi: 10.1002/sd.344

Doherty, T. J. (2009). Ecopsychology Roundtable: Identity, Well-Being, and Sustainability. Ecopsychology, 1(4), 169-174. doi: 10.1089/eco.2010.0006

Dono, J., Webb, J., és Richardson, B. (2010). The relationship between environmental activism, pro-environmental behaviour and social identity. Journal of Environmental Psychology, 30(2), 178-186. doi: 10.1016/j.jenvp.2009.11.006

Doppelt, B. (2012). From Me to We: The Five Transformational Commitments Required to Rescue the Planet, Your Organization, and Your Life. Sheffield: Greenleaf Publishing

Drexhage, J., és Murphy, D. (2010). Sustainable Development: From Brundtland to Rio 2012.

Dunlap, R. E. (2002). Environmental Sociology Bechtel, R. B. és Churhman, A. (Eds.), Handbook of Environmental Psychology. New York: John Wiley \& Sons, Inc.

Dunlap, R. E., és Van Liere, K. D. (1978). The new environmental paradigm:A proposed measuring instrument. The Journal of Environmental Education, 9(1), 10-19. doi: 10.1080/00958964.1978.10801875

Dunlap, R. E., Van Liere, K. D., Mertig, A. G., és Jones, R. E. (2000). Measuring Endorsement of the New Ecological Paradigm: A Revised NEP Scale. Journal of Social Issues, 56(3), 425-442. doi: 10.1111/0022-4537.00176

Dupont, D. P. (2004). Do children matter? An examination of gender differences in environmental valuation. Ecological Economics, 49(3), 273-286. doi: http://dx.doi.org/10.1016/j.ecolecon.2004.01.013

Dutcher, D., Finley, J. C., Luloff, A. E., és Johnson, J. B. (2007). Connectivity with nature as a measure of environmental values. Environment and Behavior, 39(4), 474-493. doi: 10.1177/0013916506298794

Eagly, A. (1987). Gender differences in social behavior: A social role interpretation. Hillsdale, NJ: Lawrence Erlbaum.

Eagly, A., és Chaiken, S. (1993). The psychology of attitudes. Fort Worth, Texas: Harcourt Brace Jovanovich College Publishers

Ellen, P. S., Wiener, J. L., és Cobb-Walgren, C. (1991). The Role of Perceived Consumer Effectiveness in Motivating Environmentally Conscious Behaviors. Journal of Public Policy and Marketing, 10(2), 102-117.

Engel, J., Blackwell, R., és Miniard, P. (1990). Consumer Behavior. Chicago: Dryden Press.

ENSZ (1987). Közös jövőnk, Brundtland-jelentés.

EurópaiBizottság (2010). Átgondoltabban, tisztábban. Fenntartható fogyasztás és termelés.

Fazio, R. H., Chen, J., McDonel, E. C., és Sherman, S. J. (1982). Attitude accessibility, attitude behavior consistency, and the strength of the object evaluation 
association. Journal of Experimental Social Psychology, 18(4), 339-357. doi: 10.1016/0022-1031(82)90058-0

Fazio, R. H., és Olson, M. A. (2003). Implicit measures in social cognition research: Their Meaning and Use. Annual Review of Psychology, 54(1), 297. doi: 10.1146/annurev.psych.54.101601.145225

Fazio, R. H., Sanbonmatsu, D. M., Powell, M. C., és Kardes, F. R. (2008). On the automatic activation of attitudes Fazio, R. H. és Petty, R. E. (Eds.), Attitudes: Their structure, function, and consequences (pp. 17-32). New York: Psychology Press

Festinger, L. (1954). A theory of social comparison processes. Human Relations, 7, $117-140$.

Festinger, L. (2000). A kognitív disszonancia elmélete. Budapest: Osiris Kiadó.

Fielding, K. S., McDonald, R., és Louis, W. R. (2008). Theory of planned behaviour, identity and intentions to engage in environmental activism. Journal of Environmental Psychology, 28(4), 318-326. doi: 10.1016/j.jenvp.2008.03.003

Forehand, M., Deshpande, R., és Reed, A. (2002). Identity Salience and the Influence of Differential Activation of the Social Self-schema on Advertising Response. Journal of Applied Psychology, 87(6), 1086-1099. doi: 10.1037/00219010.87.6.1086

Forehand, M. R., és Deshpandé, R. (2001). What we see makes us who we are: Priming ethnic self-awareness and advertising response. Journal of Marketing Research, 38(3), 336-348. doi: 10.1509/jmkr.38.3.336.18871

Fornell, C., és Larcker, D. F. (1981). Evaluating structural equation models with unobservable variables and measurement error. Journal of Marketing Research, 18(1), 39-50.

Frantz, C., Mayer, F. S., Norton, C., és Rock, M. (2005). There is no "I" in nature: The influence of self-awareness on connectedness to nature. Journal of Environmental Psychology, 25(4), 427-436. doi: 10.1016/j.jenvp.2005.10.002

Freedman, D., Pisani, R., és Purves, R. (2007). Statistics (4 ed.). New York: Norton and Company.

Fromm, E. (1993). A szeretet müvészete. Budapest: Háttér Kiadó.

Füstös, L., és Szalma, I. (2010). Európa értékrendszere. Magyarország értéktere Európa értéktere.

Gatersleben, B. (2012). Measuring environmental behaviour Steg, L., Van Den Berg, A. E. és De Groot, J. I. M. (Eds.), Environmental Psychology. Oxford: BPS Blackwell

Gatersleben, B., Steg, L., és Vlek, C. (2002). Measurement and Determinants of Environmentally Significant Consumer Behavior. Environment \& Behavior, 34(3), 335-362. doi: 10.1177/0013916502034003004

Giddings, B., Hopwood, B., és O'Brien, G. (2002). Environment, economy and society: fitting them together into sustainable development. Sustainable Development, 10, 187-196.

Goffman, E. (1959). The presentation of self in everyday life. New York: Anchor. 
Gonzales, M. H., Aronson, E., és Costanzo, M. A. (1988). Using social cognition and persuasion to promote energy conservation: A quasi-experiment. Journal of Applied Social Psychology, 18(12), 1049-1066. doi: 10.1111/j.15591816.1988.tb01192.x

Gosling, E., és Williams, K. J. H. (2010). Connectedness to nature, place attachment and conservation behaviour: Testing connectedness theory among farmers. Journal of Environmental Psychology, 30(3), 298-304. doi: 10.1016/j.jenvp.2010.01.005

Greenwald, A. G., és Banaji, M. R. (1995). Implicit social cognition: Attitudes, selfesteem, and stereotypes. Psychological Review, 102(1), 4-27. doi: 10.1037/0033-295X.102.1.4

Greenwald, A. G., és Farnham, S. D. (2000). Using the Implicit Association Test to Measure Self-Esteem and Self-Concept. Journal of Personality and Social Psychology, 79(6), 1022-1038. doi: 10.1037/0022-3514.79.6.1022

Greenwald, A. G., McGhee, D. E., és Schwartz, J. L. K. (1998). Measuring individual differences in implicit cognition: The Implicit Association Test. Journal of Personality and Social Psychology, 74(6), 1464-1480. doi: 10.1037/00223514.74.6.1464

Greenwald, A. G., Nosek, B. A., és Banaji, M. R. (2003a). Understanding and Using the Implicit Association Test: I. An Improved Scoring Algorithm. Journal of Personality and Social Psychology, 85(2), 197-216. doi: 10.1037/00223514.85.2.197

Greenwald, A. G., Nosek, B. A., és Banaji, M. R. (2003b). Understanding and using the Implicit Association Test: I. An improved scoring algorithm. Journal of Personality and Social Psychology, 85(2), 197-216.

Greenwald, A. G., Nosek, B. A., és Sriram, N. (2006). Consequential validity of the Implicit Association Test: Comment on the article by Blanton and Jaccard. American Psychologist, 61, 56-61.

Grob, A. (1995). A structural model of environmental attitudes and behaviour. Journal of Environmental Psychology, 15(3), 209-220. doi: 10.1016/02724944(95)90004-7

Groot, J. I. M. d., és Steg, L. (2010). Relationships between value orientations, selfdetermined motivational types and pro-environmental behavioural intentions. Journal of Environmental Psychology, 30(4), 368-378. doi: 10.1016/j.jenvp.2010.04.002

Gross, S. J., és Niman, C. M. (1975). Attitude-Behavior Consistency: A Review. The Public Opinion Quarterly, 39(3), 358-368. doi: 10.1086/268234

Gunderson, K. I. (1989). The state of environmental education in Montana public schools. University of Montana, Missoula.

Hair, J. F. J., Black, W. C., Babin, B. J., és Anderson, R. E. (2010). Multivariate Data Analysis: A Global Perspective (7 ed.). New Jersey: Pearson Education Inc.

Harangozó, G. (2011). A visszapattanó hatás jelentősége az energiafelhasználás csökkentésében Csutora, M. (Ed.), Az ökológiai lábnyom ökonómiája (pp. 108-118). Budapest: AULA Kiadó 
Hawcroft, L. J., és Milfont, T. L. (2010). The use (and abuse) of the new environmental paradigm scale over the last 30 years: A meta-analysis. Journal of Environmental Psychology, 30(2), 143-158. doi: 10.1016/j.jenvp.2009.10.003

Heberlein, T. A. (1977). Norm Activation and Environmental Action: A Rejoinder to R. E. Dunlap and K. D. Van Liere. Journal of Social Issues, 33(3), 207-211. doi: DOI: 10.1111/j.1540-4560.1977.tb01892.x

Heider, F. (1958.). The psychology of interpersonal relations. New York: Wiley.

Henion, K. E., és Kinnear, T. C. (1976). Ecological Marketing.

Henseler, J., Ringle, C. M., és Sinkovics, R. R. (2009). The use of partial least squares path modeling in international marketing. Advances in International Marketing, 20, 277-319.

Herzog, T. R., Black, A. M., Fountaine, K. A., és Knotts, D. J. (1997). Reflection and attentional recovery as distinctive benefits of restorative environments. Journal of Environmental Psychology, 17(2), 165-170. doi: 10.1006/jevp.1997.0051

Hinds, J., és Sparks, P. (2008). Engaging with the natural environment: The role of affective connection and identity. Journal of Environmental Psychology, 28(2), 109-120. doi: 10.1016/j.jenvp.2007.11.001

Hines, J. M., Hungerford, H. M., és Tomera, A. N. (1986). Analysis and synthesis of research on responsible pro-environmental behavior: a meta-analysis. The Journal of Environmental Education, 18(2), 1-8. doi: 10.1080/00958964.1987.9943482

Hirsh, J. B. (2010). Personality and environmental concern. Journal of Environmental Psychology, 30(2), 245-248. doi: 10.1016/j.jenvp.2004.09.001

HoffmannIstvánné. (2006). A fenntartható fogyasztás társadalmi elfogadottsága. In Bulla, M. és Tamás, P. (Eds.), Fenntartható fejlődés Magyarországon (pp. 311322). Budapest: Új Mandátum Könyvkiadó. Retrieved from www.socio.mta.hu/dynamic/5_fenntarthato_fejlodes.pdf.

Hofmeister-Tóth, Á., Kasza-Kelemen, K., és Piskóti, M. (2013). A környezetbarát fogyasztói magatartás formái, motivációi és a hátterükben álló pszichográfiai tényezők vizsgálata Magyarországon. [Motivations and psychographic factors of environmentally friendly consumer behaviour in Hungary]. Marketing és Menedzsment, 47(3), 34-42.

Hofmeister-Tóth, Á., Kelemen, K., és Piskóti, M. (2011). Environmentally Conscious Consumption Patterns in Hungarian Households. Society and Economy in Central and Eastern Europe 33(1), 51-68. doi: 10.1556/SocEc.33.2011.1.6

Hofmeister-Tóth, Á., Kelemen, K., és Piskóti, M. (2012a). Life paths in Hungary in the light of commitment to sustainability. Interdisciplinary Environmental Review, 13(4), 323-339. doi: 10.1504/IER.2012.051449

Hofmeister-Tóth, Á., Kelemen, K., és Piskóti, M. (2012b). Segmentation of the Hungarian consumers using the new ecological paradigm (NEP) scale. Interdisciplinary Environmental Review, 13(1), 21-41. doi: 10.1504/IER.2012.046098

Hofmeister-Tóth, Á., és Töröcsik, M. (1996). Fogyasztói magatartás. Budapest: Nemzeti Tankönyvkiadó. 
Hogg, M. A., Terry, D. J., és White, K. M. (1995). A Tale of Two Theories: A Critical Comparison of Identity Theory with Social Identity Theory. Social Psychology Quarterly, 58(4), 255-269.

Homburg, C., és Klarmann, M. (2006). Die Kausalanalyse in der betriebswirtschaftlichen Forschung - Problemfelder und Anwendungsempfehlungen. DBW - Die Betriebswirtschaft, 66(6), 727-748.

Homer, P., és Kahle, L. R. (1988). A Structural Equation Test of the Value-AttitudeBehavior Hierarchy. Journal of Personality and Social Psychology, 54(4), 638646. doi: 10.1037/0022-3514.54.4.638

Hovland, C. I., és Weiss, W. (1951). The influence of source credibility on communication effectiveness. Public Opinion Quarterly, 15(4), 635-650. doi: $10.1086 / 266350$

Hurley, A. E., Scandura, T. A., Schriesheim, C. A., Brannick, M. T., Seers, A., Vanderberg, R. J., és Williams, L. J. (1997). Exploratory and con®rmatory factor analysis: guidelines, issues, and alternatives. Journal of Organizational Behavior, 18, 667-683.

Jackson, T. (2005a). Live Better by Consuming Less? Is There a "Double Dividend" in Sustainable Consumption? Journal of Industrial Ecology, 9(1-2), 19-36. doi: $10.1162 / 1088198054084734$

Jackson, T. (2005b). Motivating Sustainable Consumption: a review of evidence on consumer behaviour and behavioural change Retrieved from http://www.compassnetwork.org/images/upload/MotivatingSCfinal.pdf

Jackson, T. (2009). Prosperity without Growth?

James, W. (1890). Principles of psychology. New York: Holt.

Joireman, J. A., Lasane, T. P., Bennett, J., Richards, D., és Solaimani, S. (2001). Integrating social value orientation and the consideration of future consequences within the extended norm activation model of proenvironmental behaviour. British Journal of Social Psychology, 40(1), 133-155. doi: 10.1348/014466601164731

Jones, R. E., és Dunlap, R. E. (1992). The social bases of environmental concern: Have they changed over time? Rural Sociology, 57, 28-47.

Kahle, L. R. (1983). Social Values and Social Change: Adaptation to Life in America. New York: Praeger.

Kahle, L. R., Beatty, S. E., és Homer, P. (1986). Alternative Measurement Approaches to Consumer Values: The List of Values (LOV) and Values and Life Style (VALS). Journal of Consumer Research, 13(3), 405-409.

Kaiser, F. G., Byrka, K., és Hartig, T. (2010). Reviving Campbell's Paradigm for Attitude Research. Personality and Social Psychology Review, 14(4), 351-367. doi: $10.1177 / 1088868310366452$

Kaiser, F. G., és Wilson, M. (2004). Goal-directed conservation behavior: the specific composition of a general performance. Personality and Individual Differences 36(7), 1531-1544. doi: 10.1016/j.paid.2003.06.003

Kamakura, W. A., és Novak, T. P. (1992). Value-System Segmentation: Exploring the Meaning of LOV. Journal of Consumer Research, 19(1), 119-132. 
Kaplan, S. (1995). The restorative benefits of nature: Toward an integrative framework. Journal of Environmental Psychology, 15(3), 169-182. doi: 10.1016/0272-4944(95)90001-2

Kaplan, S. (2000). Human Nature and Environmentally Responsible Behavior. Journal of Social Issues, 56(3), 491-508. doi: 10.1111/0022-4537.00180

Karp, D. G. (1996). Values and their effect on pro-environmental behavior. Environment \& Behavior, 28(1), 111-133. doi: 10.1177/0013916596281006

Kellert, S. R. (1993). Attitudes, knowledge, and behavior toward wildlife among the industrial superpowers: United States, Japan, and Germany. Journal of Social Issues, 49(1), 53-69. doi: 10.1111/j.1540-4560.1993.tb00908.x

Kellert, S. R. (2002). Experiencing Nature: Affective, Cognitive, and Evaluative Development in Children Kahn, P. H. és Kellert, S. R. (Eds.), Children and Nature. Psychological, Sociocultural, and Evolutionary Investigations (pp. 117-152). Cambridge, Massachusetts: The MIT Press

Kerekes, S. (2011). Boldogság, környezetvédelem és piacgazdaság Csutora, M. és Hofmeister-Tóth, Á. (Eds.), Fenntartható fogyasztás? (pp. 4-10). Budapest: Aula Nyomda (ISBN:978-963-503-465-9).

Kerekes, S. (2012). A környezetügy ötven éve Kerekes, S. és Csutora, M. (Eds.), Fenntartható fogyasztás? Trendek és lehetőségek Magyarországon (pp. 9-20). Budapest: AULA Kiadó

Ketskeméty, L., Izsó, L., és KönyvesTóth, E. (2011). Bevezetés az IBM SPSS Statistics programrendszerbe (3 ed.). Budapest: Artéria Stúdió Kft. (ISBN:978-963-081100-2).

Kiesling, F. M., és Manning, C. M. (2010). How green is your thumb? Environmental gardening identity and ecological gardening practices. Journal of Environmental Psychology, 30(3), 315-327. doi: 10.1016/j.jenvp.2010.02.004

Kilbourne, W. E., és Beckmann, S. C. (1998). Review and critical assessment of research on marketing and the environment. Journal of Marketing Management, 14, 513-532.

Kiss, A., és Pikó, B. (2004). Az elidegenedett én a modern, fogyasztói társadalomban. Valóság, XLVII(7).

Kleine, R. E., Kleine, S. S., és Kernan, J. B. (1993). Mundane consumption and the self: A social identity perspective. Journal of Consumer Psychology, 2(3), 209235. doi: 10.1016/S1057-7408(08)80015-0

Koger, S. M., és Scott, B. A. (2007). Psychology and environmental sustainability: a call for integration. Teaching of psychology, 34(1), 10-18.

Kollmuss, A., és Agyeman, J. (2002). Mind the gap: why do people act environmentally and what are the barriers to pro-environmental behavior? Environmental Education Research, 8(3), 239-260.

Kónya, A. (Ed.). (1990). Az emberi emlékezet pszichológiai elméletei. Budapest: Tankönyvkiadó.

Kotler, P., és Zaltman, G. (1971). Social Marketing: an Approach to Planned Social Change. Journal of Marketing, 35(3), 3-12. 
Kraus, S. J. (1995). Attitudes and the Prediction of Behavior: A Meta-Analysis of the Empirical Literature. Personality and Social Psychology Bulletin, 21(1), 5875. doi: 10.1177/0146167295211007

Kuhn, M. H. (1964). Major trends in symbolic interaction theory in the past twenty-fi ve years. The Sociological Quarterly, 5, 61-84.

Kurucz, I. (2012). Hogyan tovább, internetpenetráció? Marketingkutató, 1(3), 23-25. Retrieved from marketingkutato.hu website: http://marketingkutato.hu/kuruczimre-hogyan-tovabb-internetpenetracio/

Lányi, A. (2007). A fenntartható társadalom. Budapest: L'Harmattan.

Lányi, K. (2008). A környezetvédö viselkedés és az egészségviselkedés összefüggése. doktori disszertáció, Debreceni Egyetem, Debrecen.

Laroche, M., Bergeron, J., és Barbaro-Forleo, G. (2001). Targeting consumers who are willing to pay more for environmentaly friendly products. Journal of Consumer Marketing, 18(6), 503-520. doi: http://dx.doi.org/10.1108/EUM0000000006155

Laverie, D. A., Kleine, R. E., és Kleine, S. S. (2002). Re-examination and extension of Kleine, Kleine, and Kernan's Social identity model of mundane consumption: The mediating role of the appraisal process. Journal of Consumer Research, 28(4), 659-669. doi: 10.1086/338208

Leary, M. R. (2007). Motivational and emotional aspects of the self. Annual Review of Psychology, 58, 317-344.

Leary, M. R., és Tangney, J. P. (2003). Handbook of self and identity New York: The Guilford Press.

Leonidou, L. C., Leonidou, C. N., és Kvasova, O. (2010). Antecedents and outcomes of consumer environmentally friendly attitudes and behaviour. Journal of Marketing Management, 26(13-14), 1319-1344. doi: 10.1080/0267257X.2010.523710

Leopold, A. C. (1949). A Sand County Almanac. New York: Oxford University Press.

Leopold, A. C. (2004). Living with the Land Ethic. BioScience, 54(2), 149-154. doi: 10.1641/0006-3568(2004)054[0149:LWTLE]2.0.CO;2

Levin, J. D. (1992). Theories of the Self Washington, DC: Hemisphere Publisher Corporation.

Levitt, L., és Leventhal, G. (1986). Litter reduction: How effective is the New York State Bottle Bill? Environment and Behavior, 18(4), 467-479. doi: $10.1177 / 0013916586184003$

Lewis, J. D., és Smith, R. L. (1980). American sociology and pragmatism: Mead, Chicago sociology, and symbolic interaction. Chicago: University of Chicago Press.

Maccoby, N., és Maccoby, E. E. (1961). Homeostatic Theory in Attitude Change. The Public Opinion Quarterly, 25(4), 538-545. doi: 10.1086/267049

Madrigal, R. (2001). Social identity effects in a belief - attitude - intentions hierarchy: Implications for corporate sponsorship Psychology and Marketing, 18(2), 145165. doi: 10.1002/1520-6793(200102)18:2<145::AID-MAR1003>3.0.CO;2-T 
Maison, D., Greenwald, A. G., és Bruin, R. (2001). The Implicit Association Test as a measure of implicit consumer attitudes. Polish Psychological Bulletin, 32(1), 61-69.

Malhotra, N. K., és Simon, J. (2009). Marketingkutatás. Budapest: Akadémiai Könyvkiadó.

Maloney, M. P., és Ward, M. P. (1973). Ecology: Let's hear from the people: An objective scale for the measurement of ecological attitudes and knowledge.

American Psychologist, 28(7), 583-586. doi: http://dx.doi.org/10.1037/h0034936

Markus, H., és Cross, S. (1990). The interpersonal self Pervin, L. A. (Ed.), Handbook of Personality (pp. 576-608). New York: Guilford Press

Mayer, F. S., és Frantz, C. M. (2004). The connectedness with nature scale: a measure of individuals' feeling in community with nature. Journal of Environmental Psychology, 24(4), 503-515. doi: 10.1016/j.jenvp.2004.10.001

Mayer, F. S., Frantz, C. M., Bruehlman-Senecal, E., és Dolliver, K. (2009). Why Is Nature Beneficial? Environment and Behavior, 41(5), 607-643. doi: 10.1177/0013916508319745

McBroom, W. H., és Reed, F. W. (1992). Toward a Reconceptualization of AttitudeBehavior Consistency. Social Psychology Quarterly, 55(2), 205-216.

McCall, G. J. (2013). Interactionist Perspectives in Social Psychology DeLamater, J. és Ward, A. (Eds.), Handbook of Social Psychology. Dortrecht: Springer

McGuire, W. J. (1979). Az attitüdök természete és az attitüdváltozás Halász, L., Hunyady, G. és Marton, M. L. (Eds.), Az attitüd pszichológiai kutatásának kérdései (pp. 57-104). Budapest: Akadémiai Kiadó

McGuire, W. J., és McGuire, C. V. (1988). Content and process in the experience of self Berkowitz, L. (Ed.), Advances in experimental social psychology (Vol. 21, pp. 97-144). New York: Academic Press

McKenzie-Mohr, D. (2000). Promoting Sustainable Behavior: An Introduction to Community-Based Social Marketing. Journal of Social Issues, 56(3), 543-554.

McKenzie-Mohr, D., Nemiroff, L. S., Beers, L., és Desmarais, S. (1995). Determinants of responsible environmental behavior. Journal of Social Issues, 51(4), 139156.

McKibben, W. (1989). The end of nature. New York: Random House.

Mead, G. H. (2000). A pszichikum, az én és a társadalom szociálbehaviorista szempontból Felkai, G., Némedi, D. és Somlai, P. (Eds.), Olvasókönyv a szociológia történetéhez. Szociológiai irányzatok a XX. század elejéig (pp. 258-271). Budapest: Új Mandátum Könyvkiadó

Meffert, H., és Kirchgeorg, M. (1993). Marktorientiertes Umweltmanagement. Grundlagen und Fallstudien. Stuttgart: Schäffer Verlag.

Merchant, C. (1992). Radical ecology: The search for a livable world. New York: Routledge, Chapman and Hall.

Milfont, T. L., és Duckitt, J. (2004). The structure of environmental attitudes:A firstand second-order confirmatory factor analysis. Journal of Environmental Psychology 24(3), 289-303. doi: 10.1016/j.jenvp.2004.09.001 
Moisander, J. (2007). Motivational complexity of green consumerism. International Journal of Consumer Studies, 31(4), 404-409. doi: 10.1111/j.14706431.2007.00586.x

Naess, A. (1985). Identification as a source of deep ecological attitudes Tobais, M. (Ed.), Deep ecology (pp. 256-270). San Diego: Avant Books

Naess, A. (2005). Önmegvalósítás Lányi, A. és Jávor, B. (Eds.), Környezet és Etika (pp. 221-236). Budapest: L'Harmattan Kiadó

Nagy, S., Piskóti, I., Molnár, L., és Marien, A. (2012). The relationship between values and general environmental behaviour. Economics and Management, 17(1), 272-278. doi: http://dx.doi.org/10.5755/j01.em.17.1.2278

NationalGeographics, és Globescan (2012). Greendex 2012: Consumer Choice and the Environment - A Worldwide Tracking Survey. Elérhető: http://environment.nationalgeographic.com/environment/greendex/

NationalGeographics, és Globescan (2014). Greendex 2014: Consumer Choice and the Environment - A Worldwide Tracking Survey. Elérhető: http://images.nationalgeographic.com/wpf/mediacontent/file/2014_Global_Report-cb1411689801.pdf

Nelson, M. R., Shavitt, S., Schennum, A., és Barkmeier, J. (1997). Prediction of longterm advertising effectiveness: New cognitive response approaches Wells, W. D. (Ed.), Measuring advertising effectiveness: Advertising and consumer psychology (pp. 133-155). Mahwah, New Jersey: Lawrence Erlbaum Associates, Inc,

Neulinger, Á. (2001). Fogyasztói értékek és vásárlói magatartás. Marketing és Menedzsment, 35(1), 30-36.

NFFT (2010). Jövőkereső. A Nemzeti Fenntartható Fejlődési Tanács jelentése a magyar társadalomnak.

Nielsen (2011). Sustainable Efforts and Environmental Concerns around the World. Elérhető: http://www.nielsen.com/us/en/insights/reportsdownloads/2011/sustainable-efforts-environmental-concerns.html

Nisbet, E. K., Zelenski, J. M., és Murphy, S. A. (2009). The Nature Relatedness Scale. Environment and Behavior, 41(5), 715-740. doi: 10.1177/0013916508318748

Norusis, M. J. (1993). SPSS for Windows: Base System User's Guide. Englewood Cliffs: Prentice Hall. (ISBN:0131788566, 9780131788565).

Nosek, B. A., Hawkins, C. B., és Frasier, R. S. (2011). Implicit social cognition: from measures to mechanisms. Social Trends in Cognitive Sciences, 15(4), 152-159. doi: 10.1016/j.tics.2011.01.005

Nunnally, J. C. (1967). Psychometric theory. New York: McGraw-Hill. (ISBN:0070474656).

Oakes, P. J., Haslam, S. A., és Turner, J. C. (1999). Megismerés és csoport: társas identitás és önkategorizáció Hunyady, G., Hamilton, D. L. és Nguyen Luu, L. A. (Eds.), A csoportok percepciója (pp. 446-470). Budapest: Akadémiai Kiadó

Olivos, P., és Aragonés, J.-I. (2011). Psychometric properties of the Environmental Identity Scale (EID). Psyecology, 2(1), 65-74. doi: $10.1174 / 217119711794394653$ 
Olivos, P., Aragonés, J.-I., és Amérigo, M. (2011). The Connectedness to nature Scale and its relationship wuth Environmental Beliefs and Identity. International Journal of Hispanic Psychology, 4(1), 5-19.

Olson, J., és Zanna, M. (1993). Attitudes and attitude change. Annual Review of Psychology, 44, 117-154. doi: 10.1146/annurev.ps.44.020193.001001

Opotow, S., és Clayton, S. (1994). Green justice: conceptions of fairness and the natural world. Journal of Social Issues, 50(3), 1-11. doi: 10.1111/j.15404560.1994.tb02416.x

Ottman, J. (2011). The New Rules of Green Marketing: Strategies, Tools, and Inspiration for Sustainable Branding. Sheffield: Greenleaf Publishing Limited.

Owens, T. J., és Samblanet, S. (2013). Self and Self-Concept DeLamater, J. és Ward, A. (Eds.), Handbook of Social Psychology (pp. 225-250). Dordrecht: Springer

Ölander, F., és Thøgersen, J. (1995). Understanding Consumer Behaviour as Prerequisite for Environmental Protection. Journal of Consumer Policy, 18(4), 345-385. doi: 10.1007/BF01024160

Palmer, J. A. (1993). Development of concern for the environment and formative experiences of educators. The Journal of Environmental Education, 24(3), 2630. doi: 10.1080/00958964.1993.9943500

Palmer, J. A., és Suggate, J. (1996). Influences and experiences affecting the proenvironmental behavior of educators. Environmental Education Research, 2(1), 109-121. doi: 10.1080/1350462960020110

Pataki, F. (2008). Az "eltünt én" nyomában. Magyar Pszichológiai Szemle, 63(3), 409470. doi: 10.1556/MPSzle.63.2008.3.1

Perkins, A., Forehand, M., Greenwald, A., és Maison, D. (2008). Measuring the Nonconscious: Implicit Social Cognition in Consumer Behavior Haugtvedt, C. P.-., Herr, P. M. és Kardes, F. R. (Eds.), Handbook of Consumer Psychology. New York: Taylor \& Francis Group, LLC

Perrin, J. L., és Benassi, V. A. (2009). The connectedness to nature scale: A measure of emotional connection to nature? Journal of Environmental Psychology, 29(4), 434-440. doi: 10.1016/j.jenvp.2009.03.003

Piskóti, M. (2013). Nature and Self - The presence of Environmental Identity in narratives in Hungary. Global Business \& Economics Anthology, 1, 262-274.

Rauwald, K. S., és Moore, C. F. (2002). Environmental attitudes as predictors of policy support across three countries Environment and Behavior, 34(6), 709-739. doi: $10.1177 / 001391602237243$

Raykov, T. (1998). Cronbach's Coefficient Alpha and the reliability of composite scales with interrelated non-homogeneous items. Applied Psychological Measurement, 22, 375-385.

Raykov, T., és Grayson, D. A. (2003). A test for change of composite reliability in scale development. Multivariate Behavioral Research, 38, 143-159.

Reed, A. (2002). Social Identity as a Useful Perspective for Self-Concept-based Consumer Research. Psychology \& Marketing, 19(3), 235-266. doi: 10.1002/mar.10011 
Reed, A. (2004). Activating the self-importance of consumer selves: Exploring identity salience effects on judgments. Journal of Consumer Research, 31(2), 286-295. doi: 10.1086/422108

Reed, A., és Forehand, M. (2003). Social identity and marketing research: An integrative framework from https://marketing.wharton.upenn.edu/profile/204/research/?pubFilter=workin gPaper

Roberts, J. A. (1996). Green consumers in the 1990s: profile and implications for advertising. Journal of Business Research, 36(3), 217-231. doi: 10.1016/01482963(95)00150-6

Roberts, J. A., és Bacon, D. R. (1997). Exploring the subtle relationships between environmental concern and ecologically conscious consumer behavior. Journal of Business Research, 40(1), 79-89.

Rokeach, M. (1973). The nature of human values. New York: Free Press.

Rosenberg, M. J., és Hovland, C. I. (1960). Cognitive, affective and behavioral components of attitudes Hovland, C. I. és Rosenberg, M. J. (Eds.), Attitude organisation and change. New Haven: Yale University Press

Roszak, T. (1992). The voice of the earth: An exploration of eco-psychology. New York: Simon \& Schuster.

Roszak, T., Gomes, M. E., és Kanner, A. D. (Eds.). (1995). Ecopsychology: Restoring the earth, healing the mind. San Francisco: Sierra Club Books.

Ryan, M., és Bate, A. (2001). Testing the Assumptions of Rationality, Continuity and Symmetry when applying discrete choice experiments in health care. Applied Economics, 8(1), 59-63. doi: 10.1080/135048501750041312

Sajtos, L., és Mitev, A. (2007). SPSS kutatási és adatelemzési kézikönyv. Budapest: Alinea Kiadó.

Schuett, M. A., és Ostergren, D. (2003). Environmental concern and involvment of individuals in selected voluntary associations. The Journal of Environmental Education, 34(4), 30-38. doi: 10.1080/00958960309603485

Schultz, P. W. (2000). Empathizing With Nature: The Effects of Perspective Taking on Concern for Environmental Issues. Journal of Social Issues, 56(3), 391-406. doi: 10.1111/0022-4537.00174

Schultz, P. W. (2001). The Structure of Environmental Concern: Concern for Self, Other People, and the Biosphere. Journal of Environmental Psychology, 21(4), 327-339. doi: 10.1006/jevp.2001.0227

Schultz, P. W., Gouveia, V. V., Cameron, L. D., Tankhur, G., Schmuck, P., és Frane`k, M. (2005). Values and their relationship to environmental concern and conservation behaviour. Journal of Cross-Cultural Psychology, 36(4), 457475. doi: $10.1177 / 0022022105275962$

Schultz, P. W., és Oskamp, S. (1996). Effort as a Moderator of the Attitude-Behavior Relationship: General Environmental Concern and Recycling. Social Psychology Quarterly, 59(4), 375-383. 
Schultz, P. W., Shriver, C., Tabanico, J. J., és Khazian, A. M. (2004). Implicit connections with nature. Journal of Environmental Psychology, 24(1), 31-42. doi: 10.1016/S0272-4944(03)00022-7

Schultz, P. W., és Tabanico, J. J. (2007). Self, Identity, and Natural Environment: Exploring Implicit Connections with Nature. Journal of Applied Social Psychology, 37(6), 1219-1247. doi: 10.1111/j.1559-1816.2007.00210.x

Schultz, P. W., és Zelezny, L. (1999). Values as Predictors of Environmental Attitudes: Evidence for Consistency across 14 Countries. Journal of Environmental Psychology, 19(3), 255-265. doi: 10.1006/jevp.1999.0129

Schwartz, J., és Miller, T. (1991). The earth's best friends. American Demographics, 13(2), 26-35.

Schwartz, S. H. (1977). Normative influence on altruism Berkowitz, L. (Ed.), Advances in experimental social psychology (Vol. 10, pp. 221-279). New York: Academic Press

Schwartz, S. H. (1992). Universals in the content of and the structure of values: Theoretical advances and empirical tests in 20 countries Zanna, M. (Ed.), Advances in Experimental Social Psychology (pp. 1-65). Orlando, FL: Academic Press

Schwartz, S. H. (1994). Are there universal aspects in the structure and contents of human values? Journal of Social Issues, 50(4), 19-45. doi: 10.1111/j.15404560.1994.tb01196.x

Schwartz, S. H. (1999). A Theory of Cultural Values and Some Implications for Work. Applied Psychology: An International Review, 48(1), 23-47. doi: 10.1111/j.1464-0597.1999.tb00047.x

Schwartz, S. H. (2007). Basic Human Values: theory, methods, and application. RISORSA UOMO, 2, 261-283.

Schwartz, S. H., és Howard, J. A. (1980). Explanations of the moderating effect of responsibility denial on the personal norm-behavior relationship. Social Psychology Quarterly, 43, 441-446.

Schwartz, S. H., és Howard, J. A. (1982). Helping and cooperation: A selfbased motivational model Derlega, V. J. és Grzelak, J. (Eds.), Cooperation and helping behavior: Theories and research (pp. 327-353). New York: Academic press

Scitovsky, T. (1990). Az örömtelen gazdaság. Gazdaságlélektani alapvetések. Budapest: Közgazdasági és Jogi Könyvkiadó.

Sheth, J. N., Sethia, N. K., és Srinivas, S. (2011). Mindful consumption: a customer centric approach to sustainability. Journal of the Academy of Marketing Science, 39(1), 21-39. doi: 10.1007/s11747-010-0216-3

Simmons, D. D., Binney, S. E., és Dodd, B. (1992). Valuing “a clean environment.". Journal of Social Behavior and Personality, 7, 649-658.

Simmons, I. G. (1993). Interpreting nature: Cultural constructions of the environment. New York: Routledge.

Smith, A. (1759). The theory of moral sentiments. London: W. Strahan.

Smith, E. R., és Mackie, D. M. (2004). Szociálpszichológia. Budapest: Osiris Kiadó. 
Smith, R. E., és Swinyard, W. R. (1983). Attitude-Behavior Consistency: The Impact of Product Trial Versus Advertising. Journal of Marketing Research, 20(3), 257-267. doi: $10.2307 / 3151829$

Solomon, M. R. (1983). The role of products as social stimuli: A symbolic interactionism perspective. Journal of Consumer Research, 10(3), 319-329.

Somogyi, M., és Bernáth, L. (2014). A Rassz Implicit Asszociációs Teszt interneten gyüjtött adatainak elemzése magyar mintán. Alkalmazott Pszichológia, 14(1), 73-92.

Sparks, P., és Guthrie, C. A. (1998). Self-identity and the theory of planned behavior: A useful addition or an unhelpful artifice? Journal of Applied Social Psychology, 28(15), 1393-1410. doi: 10.1111/j.1559-1816.1998.tb01683.x

Sparks, P., és Shepherd, R. (1992). Self-Identity and the Theory of Planned Behavior: Assesing the Role of Identification with "Green Consumerism". Social Psychology Quarterly, 55(4), 388-399.

Stayman, D. M., és Deshpande, R. (1989). Situational ethnicity and consumer behavior. Journal of Consumer Research, 16(3), 361-371.

Steg, L., és Vlek, C. (2009). Encouraging pro-environmental behaviour: An integrative review and research agenda. Journal of Environmental Psychology, 29(3), 309317. doi: 10.1016/j.jenvp.2008.10.004

Stern, P. C. (1999). Information, Incentives, and Proenvironmental Consumer Behavior. Journal of Consumer Policy, 22, 461-478.

Stern, P. C. (2000). New Environmental Theories: Toward a Coherent Theory of Environmentally Significant Behavior. Journal of Social Issues, 56(3), 407424. doi: 10.1111/0022-4537.00175

Stern, P. C. (2005). Understanding Individuals' Environmentally Significant Behavior. Environmental Law Reporter, 35(11).

Stern, P. C., Aronson, E., Darley, J. M., Hill, D. H., Hirst, E., Kempton, W., és Wilbanks, T. J. (1985). The effectiveness of incentives for residential energy conservation. Evaluation Review, 10(2), 147-176. doi: 10.1177/0193841X8601000201

Stern, P. C., és Dietz, T. (1994). The value basis of environmental concern. Journal of Social Issues, 50(3), 65-84. doi: 10.1111/j.1540-4560.1994.tb02420.x

Stern, P. C., Dietz, T., Abel, T., Guagnano, G. A., és Kalof, L. (1999). A Value-BeliefNorm Theory of Support for Social Movements: The Case of Environmentalism. Research in Human Ecology, 6(2), 81-97.

Stets, J. E., és Burke, P. J. (2003). A Sociological Approach to Self and Identity Leary, M. R. és Tangney, J. P. (Eds.), Handbook of Self and Identity (pp. 128-152). New York: The Guilford Press

Stets, J. E., és Serpe, R. T. (2013). Identity Theory DeLamater, J. és Ward, A. (Eds.), Handbook of Social Psychology. Dordrecht: Springer

Straughan, R. D., és Roberts, J. A. (1999). Environmental segmentation alternatives: a look at green consumer behavior in the new millennium. Journal of Consumer Marketing, 16(6), 558-575. doi: 10.1108/07363769910297506 
Stryker, S. (1987). Identity Theory: Developments and Extensions Yardley, K. és Honess, T. (Eds.), Self and Identity (pp. 89-104). New York: Wiley

Stryker, S. ([1980] 2002). Symbolic interactionism: A social structural version. Caldwell, NJ: Blackburn Press.

Stryker, S., és Burke, P. J. (2000). The past, present, and future of an identity theory. Social Psychology Quarterly, 63, 284 - 297.

Stryker, S., és Serpe, R. T. (1994). Identity salience and psychological centrality: Equivalent, overlapping, or complementary concepts? Social Psychology Quarterly, 57, 16-35.

Sudbury-Riley, L., Hofmeister-Toth, A., és Kohlbacher, F. (2014). A cross-national study of the ecological worldview of senior consumers. International Journal of Consumer Studies, 38(5), 500-509. doi: DOI: 10.1111/ijcs.12126

SustainableConsumptionRoundtable (2006). I will if You will, Towards sustainable consumption.

Swann, W. B., Jr. , és Hill, C. A. (1982). When Our Identities Are Mistaken: Reaffirming Self Conceptions through Social Interaction. Journal of Personality and Social Psychology, 43, 59-66.

Swann, W. B. J., Chang-Schneider, C., és Larsen McClarty, K. (2007). Do people's self-views matter? Self-concept and self-esteem in everyday life. American Psychologist, 62, 84-94.

Székely, M. (2003). A fogyasztói magatartás alapjai: a lélek- és a gazdaságtan alapfeltevései a fogyasztásról Hunyady, G. és Székely, M. (Eds.), Gazdaságpszichológia (pp. 231-297). Budapest: Osiris Kiadó

Székelyi, M., és Barna, I. (2008). Túlélőkészlet az SPSS-hez. Többváltozós elemzési technikákról társadalomkutatók számára. Budapest: Typotex.

Szlávik, J. (2014). Lépések a fenntartható gazdálkodás irányába. Gondolatok Láng István és Kerekes Sándor Megalakult a Túlélés Szellemi Kör című vitairatához. Magyar Tudomány, Január, 99-109.

Szokolszky, Á. (2004). Kutatómunka a pszichológiában. Budapest: Osiris.

Tajfel, H. (1978). Differentiation between Social Groups. London: Academic Press.

Tajfel, H. (1982). Social psychology of intergroup relations. Annual Review of Psychology, 33, 1-39. doi: 10.1146/annurev.ps.33.020182.000245

Tamás, P. (2006). Fenntartható Magyarország - Vázlatok egy zöld társadalompolitikáról Bulla, M. és Tamás, P. (Eds.), Fenntartható fejlődés Magyarországon, Jövőképek és forgatókönyvek (pp. 12-109). Budapest: Új Mandátum Könyvkiadó

Tanner, T. (1980). Significant life experiences. The Journal of Environmental Education, 11(4), 20-24. doi: 10.1080/00958964.1980.9941386

Terry, D. J., Hogg, M. A., és White, M. A. (1999). The theory of planned behavior: Self-identity, social identity, and group norms. British Journal of Social Psychology, 38(3), 225-244. doi: 10.1348/014466699164149

Theodorakis, Y. (1994). Planned behavior, attitude strength, role identity, and the prediction of exercise behavior. The Sport Psychologist, 8, 149-165. 
Thøgersen, J. (2006). Norms for environmentally responsible behaviour: An extended taxonomy. Journal of Environmental Psychology, 26(4), 247-261. doi: 10.1016/j.jenvp.2006.09.004

Thøgersen, J., és Ölander, F. (2002). Human values and the emergence of a sustainable consumption pattern: A panel study. Journal of Economic Psychology, 23, 605-630.

Thøgersen, J., és Ölander, F. (2003). Spillover of environment-friendly consumer behaviour. Journal of Environmental Psychology, 23(3), 225-236. doi: 10.1016/S0272-4944(03)00018-5

Thøgersen, J., és Ölander, F. (2006). To what degree are environmentally beneficial choices reflective of a general conservation stance? . Environment and Behavior, 38, 550-569.

Thomashow, M. (1995). Ecological Identity: Becoming a reflective environmentalist. Cambridge, Massachusetts: MIT Press.

Thorbjørnsen, H., Pedersen, P. E., és Nysveen, H. (2007). "This Is Who I Am": Identity Expressiveness and the Theory of Planned Behavior. Psychology and Marketing, 24(9), 763-785. doi: 10.1002/mar.20183

Torgler, B., és García-Valiñas, M. A. (2007). The determinants of individuals' attitudes towards preventing environmental damage. Ecological Economics, 63(2-3), 536-552. doi: 10.1016/j.ecolecon.2006.12.013

Turner, R. H. (1978). The role and the person. The American Journal of Sociology, 84, $1-23$.

UNEP. (2001). Fenntartható fogyasztási lehetőségek. Retrieved from http://www.rec.hu/hftf/doc/SCOPEhu.pdf

Vadovics, E. (2007). Alulról jövő kezdeményezések (,,kreatív közösségek”) tanulsága és üzenete a fenntartható fogyasztást meghatározó politikák és kutatás számára. Konferencia cikk a Fenntartható Fogyasztás Magyarországon 2007 konferencián, Budapest.

Valkó, L. (2003). Fenntartható/környezetbarát fogyasztás és a magyar lakosság környezeti tudata [The sustainable/ environmentally friendly consumption and the environmentally consciousness of the Hungarian population]. Budapest: A Budapesti Közgazdaságtudományi és Államigazgatási Egyetem Környezettudományi Intézet.

Vermeir, I., és Verbeke, W. (2006). Sustainable food consumption: Exploring the consumer "attitude - behavioral intention" gap. Journal of Agricultural and Environmental Ethics, 19(2), 169-194. doi: 10.1007/s10806-005-5485-3

Watson, J. J., és Wright, K. (2000). Consumer ethnocentrism and attitudes toward domestic and foreign products. European Journal of Marketing, 34(9-10), 1149-1166. doi: 10.1108/03090560010342520

Webster, F. E. (1975). Determining the characteristics of the Socially Conscious Consumer. Journal of Consumer Research, 2(3), 188-196.

WEF (2011). The Consumption Dilemma. Leverage Points for Accelerating Sustainable Growth.

Elérhető: 
http://www.weforum.org/reports/consumption-dilemma-leverage-pointsaccelerating-sustainable-growth

Werner, C. M., Turner, J., Shipman, K., Shawn Twitchell, F., Dickson, B. R., Bruschke, G. V., és von Bismarck, W. B. (1995). Commitment, behavior, and attitude change: An analysis of voluntary recycling. Journal of Environmental Psychology, 15(3), 197-208. doi: 10.1016/0272-4944(95)90003-9

Wheeler, C. S., és Berger, J. (2007). When the same prime leads to different effects. Journal of Consumer Research, 34(3), 357-368. doi: 10.1086/518547

Wheeler, S. C., Petty, R. E., és Bizer, G. Y. (2005). Self-Schema Matching and Attitude Change: Situational and Dispositional Determinants of Message Elaboration. Journal of Consumer Research, 31(4), 787-797. doi: $10.1086 / 426613$

Whitmarsh, L., és O'Neill, S. (2010). Green identity, green living? The role of proenvironmental self-identity in determining consistency across diverse proenvironmental behaviours. Journal of Environmental Psychology, 30(3), 305314. doi: 10.1016/j.jenvp.2010.01.003

Wilson, E. O. (1984). Biophilia: The human bond with other species. Cambridge, Mass.: Harvard University Press.

Winter, D. D. N., és Koger, S. M. (2004). The psychology of environmental problems. Mahwah, New Jersey: Lawrence Erlbaum Associates, Inc.

Zavestoski, S. (2003). Constructing and Maintaining Ecological Identities Clayton, S. és Opotow, S. (Eds.), Identity and the Natural Environment: the psychological significance of nature (pp. 297-316). Cambridge, Massachusetts: The MIT Press

Zelezny, L. C., Chua, P. P., és Aldrich, C. (2000). Elaborating on gender differences in environmentalism. Journal of Social Issues, 56(3), 443-457. doi: $10.1111 / 0022-4537.00177$

Zhang, Y., és Khare, A. (2009). The Impact of Accessible Identities on the Evaluation of Global versus Local Products. Journal of Consumer Research, 36(3), 524537. doi: $10.1086 / 598794$

Zsóka, Á., MarjainéSzerényi, Z., Széchy, A., és Kocsis, T. (2013). Greening due to environmental education? Environmental knowledge, attitudes, consumer behavior and everyday pro-environmental activities of Hungarian high school and university students. Journal of Cleaner Production, 48(June), 126-138. doi: 10.1016/j.jclepro.2012.11.030

Zsóka, Á. N. (2007). A fenntartható fogyasztás alapfeltétele: a környezettudatos egyéni magatartás. Konferencia cikk a Fenntartható fogyasztás Magyarországon $2007 \quad$ konferencián, Budapest. http://www.tve.hu/attachment/file/31/Fenntarthato_fogyasztas_konferenciako tet.pdf 


\section{MELLÉKLET}

1. SZÁMÚ MELLÉKLET: KSH ADATAI A MAGYARORSZÁGI BOLDOGSÁG ÉRZÉSÉRŐL, FORRÁS: NFFT 2010, 99-100. OLD.

1 - egyáltalán nem boldog; 2 - alig boldog; 3 - egy kicsit boldog; 4 - boldog;

5 - eléggé boldog; 6 - nagyon boldog; 7 - teljesen boldog

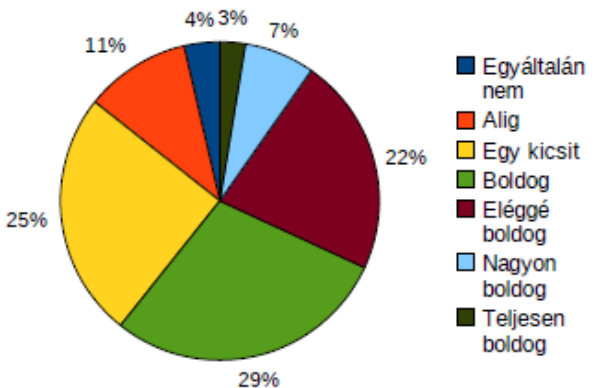

104. ábra Mennyire boldog a magyar ember?

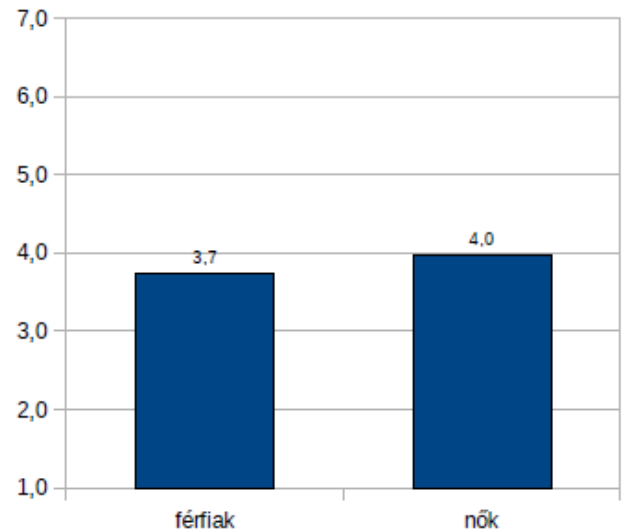

nốk

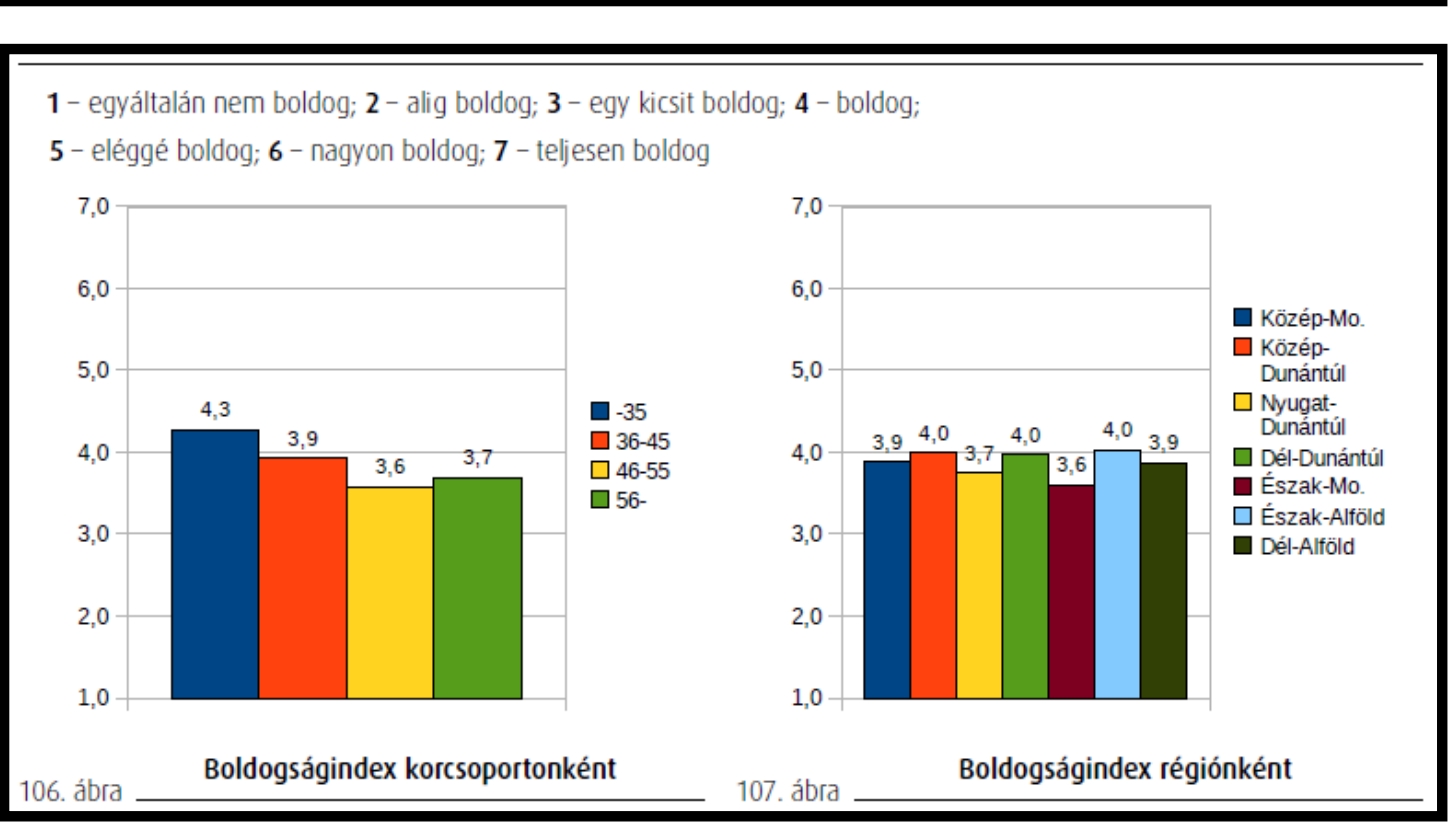




\section{SZÁMÚ MELLÉKLET: KÖRNYEZETI IDENTITÁS SKÁLA, 24 ÁLLÍTÁSOS}

Mennyire értesz egyet az alábbi állításokkal? (1= egyáltalán nem értek egyet; ... ; $5=$ teljes mértékben egyet értek)

1. Sok időt töltök természetben (erdő, hegyvidék, puszta, tópart, tengerpart).

2. Fontos számomra, hogy támogassak egyes környezetbarát cselekvéseket.

3. A természet részének érzem magam és nem kívülállónak.

4. Ha lenne elég időm vagy pénzem, egy részét biztosan környezetvédelemi ügyekre fordítanám.

5. Ha zaklatott vagy stresszes vagyok, akkor jobban érzem magam, ha valamennyi időt a szabadban tölthetek a „eggyé válva” a természettel.

6. Fontos számomra, hogy közel éljek a természethez, nem szeretnék mindig nagyvárosban élni.

7. Sok közös vonás van köztem és a környezetvédő csoportok között.

8. Hiszek benne, hogy napjaink társadalmi problémái megoldhatók lennének, ha a falusias életmódhoz térnénk vissza, ahol az emberek jobban harmóniában élnek a termőfölddel.

9. Úgy érzem, sok közös vonás van köztem és az élővilág más tagjaiban.

10. A saját érdekem általában egybeesik a környezetvédők által támogatott állásponttal.

11. Az, hogy az élővilág része vagyok, fontos részét képezi annak, aki most vagyok.

12. Úgy érzem, hogy gyökereim egy bizonyos földrajzi helyhez kapcsolódnak, mely jelentős hatással volt fejlődésemre.

13. A Földdel szembeni felelősségteljes viselkedés - azaz a fenntartható életmód követése - része az erkölcsi kódexemnek.

14. Minden gyermek nevelésének fontos része kellene, hogy legyen a természeti világról való tanulás.

15. Az önmagamról alkotott kép fontos részét képezi, hogy az élővilág része vagyok.

16. Inkább élnék egy kis szobában vagy házban egy szép kilátással, mint egy olyan nagyobb szobában vagy házban, ami más épületekre néz.

17. Nagyon élvezem a szabad levegőn történő kempingezést és túrázást.

18. Néha úgy érzem, hogy a természet egyes elemei - bizonyos fák, viharok, hegyek saját személyiséggel rendelkeznek.

19. Úgy érezem, hogy az életem egy fontos része hiányozna, ha nem tudnék kimenni a szabadba és élvezni a természetet időről időre.

20. Büszke vagyok arra, hogy pár napig egyedül is képes lennék túlélni a szabadban.

21. Még nem láttam olyan művészeti alkotást, amely olyan gyönyörü lenne, mint a természet müremeke, mint a naplemente vagy egy hegylánc.

22. Szeretek kertészkedni.

23. Úgy érzem, a természet lelki táplálékot jelent számomra.

24. Olyan tárgyakat tartok a szobámban, amelyek emlékeztetnek a környezetre, mint például kagylók, kövek vagy tollak. 
3. SZÁMÚ MELLÉKLET: KÖRNYEZETI IDENTITÁS SKÁLA, 11 ÁLLÍTÁSOS

Mennyire értesz egyet az alábbi állításokkal? (1= egyáltalán nem értek egyet; ... ; 5=teljes mértékben egyet értek)

1. Sok időt töltök természeti környezetben (erdő, hegyvidék, puszta, tópart, tengerpart).

2. Úgy tekintek magamra, mint aki a természet része, nem független tőle.

3. Ha lenne elég időm vagy pénzem, egy részét biztosan arra szánnám, hogy környezetvédelmi ügyekkel foglalkozzam.

4. Ha kiborultam, vagy csak stresszes vagyok, jobban érzem magam, ha kis időt a szabadban tölthetek élvezve a természetet.

5. Érzem sok közös vonásom van más élőlényekkel.

6. A Földdel szembeni felelősségteljes viselkedés, azaz a fenntartható életmód követése része az erkölcsi kódexemnek.

7. Minden gyermek nevelésének fontos része kellene, hogy legyen a természet világának megismerése.

8. Inkább élnék egy szép kilátással rendelkező kisebb szobában vagy házban, mint egy olyan szobában, vagy házban, amely nagyobb, de már épületekre néz.

9. Úgy érezném, életem fontos része hiányzik, ha nem tudnék időről-időre kimenni a szabadba és élvezni a természetet.

10. Még nem láttam olyan müvészeti alkotást, amely annyira gyönyörü lenne, mint a természet olyan csodái, mint a naplemente vagy egy hegylánc.

11. Úgy érzem, spirituális feltöltődést jelent számomra a természet élménye. 
4. SZÁMÚ MELLÉKLET: IDÉZETEK A TERMÉSZET ÉRTELMEZÉSÉRE KÉSZÜLT NARRATÍV ELEMZÉSBÖL

\begin{tabular}{|c|c|}
\hline \multirow[t]{2}{*}{$\begin{array}{l}\text { A természet } \\
\text { értelmezése }\end{array}$} & $\begin{array}{l}\text { „Az esö olyan hirtelen és nagy mennyiségben esett, hogy én azóta sem } \\
\text { láttam ahhoz hasonlót. A szél úgy fújt, hogy a kertünkben lévö } \\
\text { növényeket majdnem kicsavarta. Ezt követöen elkezdett dörögni és } \\
\text { villámlani. Hihetetlen egyedül éreztem magam és szó szerint féltem." } \\
\text { (25 éves, nö, megyeszékhely) }\end{array}$ \\
\hline & $\begin{array}{l}\text { „A tiszta sós víz, a hüs szél, a világos parti homok, a fölénk hajló } \\
\text { pálmafák harmóniája az emlékezetembe vésödött. Bár még kisgyerek } \\
\text { voltam, mégis olyan misztikus érzés volt mindezt látni. Lehet, hogy nem } \\
\text { ez a legjobb szó, de én mégis leginkább igy tudom kifejezni, amit } \\
\text { éreztem: egyszerre éreztem békét és a hatalmas víznek való } \\
\text { kiszolgáltatottságot. Azóta is ez az érzés tér vissza, ha a tenger partján } \\
\text { állok, és szeretem ezt az érzést, mert megtisztitja a fejem a } \\
\text { mindennapjaim nagynak gondolt gondjaitól, és segit elgondolkodni } \\
\text { önmagamról." (23 éves, nö, megyeszékhely) }\end{array}$ \\
\hline \multirow[t]{3}{*}{$\begin{array}{l}\text { A történetek } \\
\text { időbelisége }\end{array}$} & $\begin{array}{l}\text { „A természet mindig fontos szerepet játszott az életemben, mivel a Bükk } \\
\text { közelében lakom, és a szüleimmel sokat mentünk túrázni már egészen } \\
\text { kicsi koromtól kezdve. Körülbelül 10-12 éves koromig minden évben tél } \\
\text { végén felkerekedtünk, elmentünk egy kiadós túrára és közben hóvirágot } \\
\text { is szedtünk.” (23 éves, nö, megyeszékhely) }\end{array}$ \\
\hline & $\begin{array}{l}\text { „Kiskoromban, amikor még általános iskolába jártam minden hétvégén } \\
\text { szerevezett túrákon lehetett részt venni amit úgy hivtak akkor, hogy } \\
\text { „Túratábor”.” (23 éves, férfi, Budapest) }\end{array}$ \\
\hline & $\begin{array}{l}\text { „Bevallom, nagyon féltem, mert sokkal sötétebb volt az erdöben, mint } \\
\text { amire én elözetesen számitottam, igaz a Hold világitott, de ez nem sokat } \\
\text { ért, mert néhol elég sürü volt a fák lombja, de legalább valamennyire } \\
\text { láttam a kitaposott turista útvonalat.”(23 éves, nö, Budapest) }\end{array}$ \\
\hline \multirow[t]{2}{*}{$\begin{array}{l}\text { A történetek } \\
\text { társas jellege }\end{array}$} & $\begin{array}{l}\text { „Szerintem a természet önmagában is lenyügözö tud lenni, hihetetlen } \\
\text { gyönyörü szineket tud felvenni, a fák és a növények is lenyügözöek, de } \\
\text { akkor élvezem a legjobban, amikor együtt vagyok a szeretteimmel, és } \\
\text { elmondhatom, megmutathatom nekik azokat a dolgokat, amik } \\
\text { tetszenek.” (23 éves, nö, város) }\end{array}$ \\
\hline & $\begin{array}{l}\text { „Szeretem amikor egyedül lehetek kint a természetben, és } \\
\text { elmélyedhetek gondolataimban” ( } 24 \text { éves, nö, falu) }\end{array}$ \\
\hline Pozitív érzelem & $\begin{array}{l}\text { „Amikor pedig megérkeztünk, tátva maradt a szánk, olyan gyönyörü, } \\
\text { szinte festöi volt a táj. A szobánk ráadásul a tengerre nézett, és a sós } \\
\text { tengeri levegöt is nagyon jó érzés volt beszippantani." (23 éves, nö, } \\
\text { Budapest) }\end{array}$ \\
\hline
\end{tabular}




\begin{tabular}{|c|c|}
\hline & $\begin{array}{l}\text { „Felszabaditó érzés volt számomra, hogy csak mi vagyunk ott, nem } \\
\text { zavar bennünket senki úgy lehetünk együtt." (23 éves, nö, } \\
\text { megyeszékhely) }\end{array}$ \\
\hline & $\begin{array}{l}\text { „Igaziból nem is a helyes útvonal megtalálása a természet által elénk } \\
\text { görgetett akadályok legyözése a legnagyobb kihivás ezen a túrán, } \\
\text { hanem sajátmagunk legyözése. Nem csak fizikailag, hanem szellemileg } \\
\text { is nagyon felkészültnek kell lenni ehhez a túrához, mert amikor az } \\
\text { embernek már mindene fáj, nagyon nagy akarateröre van szüksége, } \\
\text { nekem ilyen kor sokat segít, ha például a madárcsicsergésre figyelek } \\
\text { vagy csak egyszerüen gyönyörködöm a tájban.” (23 éves, nö, falu) }\end{array}$ \\
\hline Életr & $\begin{array}{l}\text { „A vizet azóta is (ahogy elötte is már) nagyon szeretem, otthon érzem } \\
\text { magam benne, ami valószínüleg annak is köszönhetö, hogy vízparton } \\
\text { töltöttem minden nyaramat gyerekkoromban, illetve hogy évekig } \\
\text { úsztam egyesületben." (23 éves, nö, Budapest) }\end{array}$ \\
\hline $\begin{array}{l}\text { Vonás } \\
\text { kiemelkedősége }\end{array}$ & $\begin{array}{l}\text { „Rendszeresen járok erdökbe, túrázni, lételemem hogy közel legyek a } \\
\text { természethez.” (24 éves, nö, falu) }\end{array}$ \\
\hline Azonosulás & $\begin{array}{l}\text { „Életemben talán ekkor éreztem magam legközelebb a természethez, } \\
\text { valahogy azt éreztem, ha elvesznék az erdöben, akkor sem halnék éhen, } \\
\text { az erdö velem van és megvéd, legalább az éhhaláltól." (23 éves, nö, } \\
\text { megyeszékhely) }\end{array}$ \\
\hline Ideológia & $\begin{array}{l}\text { „Nagyon jó volt ilyen környezetben felnőni, s úgy gondolom igazán } \\
\text { boldog gyerekkorom volt. Ha majd gyerekem lesz, szeretnék neki én is } \\
\text { hasonló körülményeket biztositani." (23 éves, nö, megyeszékhely) }\end{array}$ \\
\hline
\end{tabular}




\section{SZÁMÚ MELLÉKLET: NR SKÁLA LEÍRÓ STATISZTIKÁI}

\begin{tabular}{|c|c|c|c|}
\hline NR skála & $\mathbf{N}$ & $\mathbf{M}$ & SD \\
\hline NR_1 Szeretek a szabadban lenni, még akkor is, ha rossz az idő. & 297 & 2,71 & 1,144 \\
\hline NR_2 Néhány fajnak ki kell halnia, vagy pusztulnia. & 297 & 2,07 & 1,227 \\
\hline $\begin{array}{l}\text { NR_3 Az embereknek joguk van a természeti erőforrásokat úgy használni, } \\
\text { ahogyan csak akarják. }\end{array}$ & 297 & 1,84 & ,978 \\
\hline NR_4 A tökéletes nyaralási helyszín számomra egy távoli, vad terület lenne. & 297 & 2,56 & 1,129 \\
\hline $\begin{array}{l}\text { NR_5 Mindig gondolok arra, hogy a cselekedeteim hogyan hatnak a } \\
\text { környezetre. }\end{array}$ & 297 & 2,69 & ,979 \\
\hline NR_6 Szeretem ásni a földet és bepiszkolni a kezem. & 297 & 2,40 & 1,251 \\
\hline $\begin{array}{l}\text { NR } 7 \text { A természettel és környezettel való kapcsolatom része a } \\
\text { szellemiségemnek. }\end{array}$ & 297 & 2,74 & 1,184 \\
\hline NR_8 Nagyon tájékozott vagyok a környezeti kérdésekben. & 297 & 2,54 & ,972 \\
\hline NR_9 Bárhol vagyok, figyelembe veszem a vadvilágot. & 297 & 3,09 & 1,104 \\
\hline NR_10 Nem túl gyakran megyek ki a természetbe. & 297 & 2,63 & 1,138 \\
\hline $\begin{array}{l}\text { NR_11 Bármit teszek is, nem fogja megváltoztatni a problémákat a világ más } \\
\text { helyein. }\end{array}$ & 297 & 2,70 & 1,191 \\
\hline NR_12 Nem különülök el a természettől, a része vagyok annak. & 297 & 3,26 & 1,080 \\
\hline NR_13 Ijesztő az a gondolat, hogy az erdő mélyén vagyok, távol a civilizációtól. & 297 & 2,73 & 1,300 \\
\hline NR_14 A természet iránti érzéseim nincsenek hatással arra, hogy hogyan élek. & 297 & 2,86 & 1,109 \\
\hline $\begin{array}{l}\text { NR_15 Az állatoknak, madaraknak és a növényeknek kevesebb joguknak kell } \\
\text { lennie, mint az embereknek. }\end{array}$ & 297 & 2,55 & 1,281 \\
\hline NR_16 Még a város közepén is észreveszem a természetet magam körül. & 297 & 3,67 & 1,010 \\
\hline NR_17 A természethez füződő viszonyom fontos része annak, hogy ki vagyok. & 297 & 2,98 & 1,117 \\
\hline $\begin{array}{l}\text { NR_18 A természetvédelem felesleges, mert a természet elég erős ahhoz, hogy } \\
\text { bármilyen emberi hatásból felépüljön. }\end{array}$ & 297 & 1,66 & ,910 \\
\hline NR_19 A nem emberi fajok állapota az emberek jövőjének az előrejelzője. & 297 & 3,26 & 1,095 \\
\hline NR_20 Sokat gondolok a szenvedő állatokra. & 297 & 2,57 & 1,220 \\
\hline NR_21 Szoros kapcsolatban érzem magam a Föld ö & 297 & 2,40 & 1,096 \\
\hline
\end{tabular}




\section{SZÁMÚ MELLÉKLET: KVANTITATÍV KÉRDÖÍV}

Üdvözöljük Önt az NRC legújabb kutatásának kérdőívén!

A Budapesti Corvinus Egyetem megbízásából felmérést készítünk a magyar lakosság környezetbarát viselkedéséröl. A kérdőív kitöltése maximum 30 percet vesz igénybe.

Elöre is megköszönjük, hogy válaszával segíti kutatásunkat!

Kérjük, legyen segítségünkre ebben a kutatásban, és segítse munkánkat az adatfelvételben. Az adatokat az adatvédelmi törvénynek megfelelően kezeljük, személyes adatait harmadik fél részére semmilyen körülmények között nem adjuk ki!

A kérdőívet kitöltők a kutatás lezárása után ajándék nyereménysorsoláson vesznek részt!

K0a. A következőkben az emberek többsége által keresett vagy az életük során elvárt dolgok listáját olvashatja.

Kérjük, értékelje az alábbi értékeket az alapján, hogy az Ön életében mennyire fontos szerepet töltenek be!

Kérjüik, válaszát egy kilencfokú skála segítségével adja meg, ahol az 1-es "egyáltalán nem fontos", az 9-es pedig "nagyon fontos" értelemben szerepel!

\begin{tabular}{|c|c|c|c|c|c|c|c|c|c|}
\hline & $\begin{array}{l}\text { 1- Egyáltalán } \\
\text { nem fontos }\end{array}$ & 2 & 3 & 4 & 5 & 6 & 7 & 8 & $\begin{array}{c}9- \\
\text { Nagyon } \\
\text { fontos }\end{array}$ \\
\hline Valahová tartozás & $\bigodot_{1}$ & $\begin{array}{c}\odot \\
2\end{array}$ & $\odot$ & $\odot$ & $\begin{array}{c}\odot \\
5\end{array}$ & $\sigma_{6}$ & $\odot$ & $\odot$ & $\odot_{9}$ \\
\hline $\begin{array}{l}\text { Jó kapcsolat } \\
\text { másokkal }\end{array}$ & $\odot_{1}$ & $\bigodot_{2}$ & $\begin{array}{c}\odot \\
3\end{array}$ & $\odot$ & $\begin{array}{c}\odot \\
5\end{array}$ & $\sigma_{6}$ & $\odot$ & $\odot$ & $\odot_{9}$ \\
\hline Önmegvalósítás & $\bigodot_{1}$ & $\begin{array}{c}\odot \\
2\end{array}$ & $\odot$ & $\bigodot_{4}$ & $\odot$ & $\underset{6}{\odot}$ & $\odot$ & $\odot$ & $\odot_{9}$ \\
\hline Elismertség & $\bigodot_{1}$ & $\begin{array}{c}\odot \\
2\end{array}$ & $\odot$ & $\odot$ & $\begin{array}{c}\odot \\
5\end{array}$ & $\underset{6}{\odot}$ & $\odot$ & $\odot$ & $\Theta_{9}$ \\
\hline $\begin{array}{l}\text { Szórakozás és az } \\
\text { élet élvezete }\end{array}$ & $\bigodot_{1}$ & $\bigodot_{2}$ & $\begin{array}{c}\odot \\
3\end{array}$ & $\odot$ & $\begin{array}{c}\odot \\
5\end{array}$ & $\sigma_{6}$ & $\odot$ & $\odot$ & $\Theta_{9}$ \\
\hline Biztonság & $\odot_{1}$ & $\begin{array}{c}\odot \\
2\end{array}$ & $\odot$ & $\odot$ & $\odot$ & $\underset{6}{\odot}$ & $\odot$ & $\odot$ & $\Theta_{9}$ \\
\hline Önbecsülés & $\bigodot_{1}$ & $\begin{array}{c}\odot \\
2\end{array}$ & $\bigodot_{3}$ & $\odot$ & $\odot$ & $\bigodot_{6}$ & $\odot$ & $\odot$ & $\odot_{9}$ \\
\hline $\begin{array}{l}\text { A természet } \\
\text { védelme }\end{array}$ & $\bigodot_{1}$ & ${ }_{2}$ & $\begin{array}{c}\odot \\
3\end{array}$ & $\odot$ & $\begin{array}{c}\odot \\
5\end{array}$ & $\underset{6}{\odot}$ & $\odot$ & $\odot$ & $\odot_{9}$ \\
\hline Az alkotás érzése & $\odot_{1}$ & $\Theta_{2}$ & $\odot_{3}$ & $\odot$ & $\odot$ & $\underset{6}{\odot}$ & $\odot$ & $\odot$ & $\odot_{9}$ \\
\hline
\end{tabular}


K0b. Az Ön számára melyik a legfontosabb érték a felsoroltak közül?

$\odot$

1. Valahová tartozás

2. Jó kapcsolat másokkal

3. Önmegvalósítás

4. Elismertség

5. Szórakozás és az élet élvezete

(-) Biztonság

(a) Önbecsülés

8. A természet védelme

9. Az alkotás érzése

K1. A következő kérdésekre nincsenek jó vagy rossz válaszok, az Ön véleményére vagyunk kíváncsiak az alábbi állításokkal kapcsolatban.

Mennyire ért egyet az alábbi állításokkal?

Kérjüik, válaszát egy ötfokú skála segítségével adja meg, ahol az 1-es "egyáltalán nem értek egyet", az 5-ös pedig "teljes mértékben egyetértek" értelemben szerepel!

\begin{tabular}{|c|c|c|c|c|c|}
\hline & $\begin{array}{c}\text { 1- egyáltalán } \\
\text { nem értek } \\
\text { egyet }\end{array}$ & 2 & 3 & 4 & $\begin{array}{l}\text { 5- teljes } \\
\text { mértékben } \\
\text { egyetértek }\end{array}$ \\
\hline $\begin{array}{l}\text { A kormánynak határozottabb lépéseket kell } \\
\text { tennie a környezetben található mérgező } \\
\text { anyagok eltávolítására. }\end{array}$ & $\odot_{1}$ & $\underset{2}{\odot}$ & $\underset{3}{\odot}$ & $\underset{4}{\odot}$ & $\Theta_{5}$ \\
\hline $\begin{array}{l}\text { Személyes kötelességemnek érzem, hogy a } \\
\text { klímaváltozás megakadályozásáért minden } \\
\text { lehetőt megtegyek. }\end{array}$ & $\odot_{1}$ & $\underset{2}{\odot}$ & $\underset{3}{\odot}$ & $\underset{4}{\odot}$ & $\odot_{5}$ \\
\hline $\begin{array}{l}\text { Személyes kötelességemnek érzem, hogy } \\
\text { lépéseket tegyek a levegőben, vízben és a } \\
\text { talajban lévő káros anyagok ártalmatlanítása } \\
\text { érdekében. }\end{array}$ & $\odot_{1}$ & $\begin{array}{c}\odot \\
2\end{array}$ & $\underset{3}{\odot}$ & $\underset{4}{\odot}$ & $\bigodot_{5}$ \\
\hline $\begin{array}{l}\text { A klímaváltozás megelőzése érdekében az } \\
\text { üzleti és az ipari szférának egyaránt } \\
\text { csökkentenie kellene a károsanyag } \\
\text { kibocsátást. }\end{array}$ & $\bigodot_{1}$ & $\begin{array}{c}\odot \\
2\end{array}$ & $\underset{3}{\odot}$ & $\begin{array}{c}\odot \\
4\end{array}$ & $\bigodot_{5}$ \\
\hline $\begin{array}{l}\text { A kormánynak nemzetközi szinten kell } \\
\text { nyomást gyakorolnia az élővilág } \\
\text { sokszínűségének csökkenése (fajok kihalása, } \\
\text { élőhelyek és a vadvilág pusztulása) ellen }\end{array}$ & $\bigodot_{1}$ & $\begin{array}{c}\odot \\
2\end{array}$ & $\underset{3}{\odot}$ & $\underset{4}{\odot}$ & $\bigodot_{5}$ \\
\hline $\begin{array}{l}\text { A kormánynak határozott lépéseket kell tennie } \\
\text { a károsanyag kibocsátás csökkentése, és a } \\
\text { globális éghajlatváltozás elkerülése } \\
\text { érdekében. }\end{array}$ & $\odot_{1}$ & $\begin{array}{c}\odot \\
2\end{array}$ & $\underset{3}{\odot}$ & $\underset{4}{\odot}$ & $\odot_{5}$ \\
\hline $\begin{array}{l}\text { Azok a vállalatok, amelyek távoli országokból } \\
\text { termékeket importálnak, felelősek a távoli } \\
\text { országokban jelenlévő élővilág csökkenésének } \\
\text { a megakadályozásáért. }\end{array}$ & $\bigodot_{1}$ & $\begin{array}{c}\odot \\
2\end{array}$ & $\underset{3}{\odot}$ & $\begin{array}{c}\odot \\
4\end{array}$ & $\bigodot_{5}$ \\
\hline
\end{tabular}




\begin{tabular}{|c|c|c|c|c|c|}
\hline $\begin{array}{l}\text { A hozzám hasonló embereknek minden } \\
\text { lehetségest meg kell tenniük, hogy világszerte } \\
\text { megakadályozzák az élővilág sokszínüségének } \\
\text { (fajok kihalása, élőhelyek és a vadvilág } \\
\text { pusztulása) csökkenését. }\end{array}$ & $\odot_{1}$ & $\underset{2}{Q}$ & $\underset{3}{0}$ & 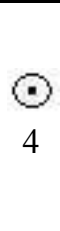 & $\Theta_{5}$ \\
\hline $\begin{array}{l}\text { A vegyiparnak meg kell tisztítania a } \\
\text { környezetet a kikerült mérgező hulladékoktól. }\end{array}$ & $\Theta_{1}$ & $\left(\begin{array}{l}Q \\
2\end{array}\right.$ & (9) & (9) & $\Theta_{5}$ \\
\hline
\end{tabular}

K2. Szokott Ön tájékozódni környezetvédelmi kérdésekben?

\section{Kötelezö:IGEN}
(2)
1. igen
(2)
2. nem

K3a. Milyen gyakran veszi igénybe a következő információforrásokat arra, hogy tájékozódjon környezetvédelmi kérdésekben?

Kérjüik, válaszát egy ötfokú skála segítségével adja meg, ahol az 1-es "egyáltalán nem", az 5-ös pedig "rendszeresen" értelemben szerepel!

\begin{tabular}{|c|c|c|c|c|c|}
\hline & $\begin{array}{l}\text { 1- egyáltalán } \\
\text { nem }\end{array}$ & 2 & 3 & 4 & $\begin{array}{c}5- \\
\text { rendszeresen }\end{array}$ \\
\hline Újságok & $\Theta_{1}$ & $\begin{array}{c}\odot \\
2\end{array}$ & $\varphi_{3}$ & $\bigodot_{4}$ & $\Theta_{5}$ \\
\hline Folyóiratok & $\odot_{1}$ & $\begin{array}{c}\odot \\
2\end{array}$ & $\begin{array}{c}\odot \\
3\end{array}$ & $\odot$ & $\odot_{5}$ \\
\hline Televíziós hírek & $\odot_{1}$ & $\begin{array}{c}\odot \\
2\end{array}$ & $\odot$ & $\begin{array}{c}\odot \\
4\end{array}$ & $\bigodot_{5}$ \\
\hline Rádió & $\odot_{1}$ & $\begin{array}{c}\odot \\
2\end{array}$ & $\bigodot_{3}$ & $\begin{array}{c}\odot \\
4\end{array}$ & $\odot_{5}$ \\
\hline $\begin{array}{l}\text { Filmek és dokumentum müsorok a TV- } \\
\text { ben }\end{array}$ & $\odot_{1}$ & $\begin{array}{c}\odot \\
2\end{array}$ & $\bigodot_{3}$ & $\begin{array}{c}\odot \\
4\end{array}$ & $\odot_{5}$ \\
\hline $\begin{array}{l}\text { Beszélgetések rokonokkal, } \\
\text { családtagokkal }\end{array}$ & $\bigodot_{1}$ & $\begin{array}{c}\odot \\
2\end{array}$ & $\odot$ & $\odot$ & $\bigodot_{5}$ \\
\hline $\begin{array}{l}\text { Beszélgetések barátokkal, } \\
\text { szomszédokkal, kollégákkal }\end{array}$ & $\odot_{1}$ & $\begin{array}{c}\odot \\
2\end{array}$ & $\odot$ & $\odot$ & $\odot_{5}$ \\
\hline Internetes oldalak, cikkek, keresők & $\odot_{1}$ & $\begin{array}{c}\odot \\
2\end{array}$ & $\odot_{3}$ & $\begin{array}{c}\odot \\
4\end{array}$ & $\odot_{5}$ \\
\hline Blogok, fórumok, közösségi oldalak & $\odot_{1}$ & $\begin{array}{c}\odot \\
2\end{array}$ & $\odot$ & $\begin{array}{c}\odot \\
4\end{array}$ & $\odot_{5}$ \\
\hline Könyvek & $\odot_{1}$ & $\begin{array}{c}\odot \\
2\end{array}$ & $\odot$ & $\begin{array}{c}\odot \\
4\end{array}$ & $\odot_{5}$ \\
\hline Szakcikkek, kiadványok, prospektusok & $\odot_{1}$ & $\begin{array}{c}\odot \\
2\end{array}$ & $\bigodot_{3}$ & $\begin{array}{c}\odot \\
4\end{array}$ & $\odot_{5}$ \\
\hline $\begin{array}{l}\text { Konferenciák, kiállítások, vásárok, } \\
\text { fesztiválok }\end{array}$ & $\odot_{1}$ & $\begin{array}{c}\odot \\
2\end{array}$ & $\odot$ & $\begin{array}{c}\odot \\
4\end{array}$ & $\odot_{5}$ \\
\hline $\begin{array}{l}\text { Civil szervezetek kiadványai, } \\
\text { rendezvényei }\end{array}$ & $\odot_{1}$ & $\begin{array}{c}\odot \\
2\end{array}$ & $\bigodot_{3}$ & $\begin{array}{c}\odot \\
4\end{array}$ & $\odot_{5}$ \\
\hline
\end{tabular}




\begin{tabular}{|c|c|c|c|c|c|}
\hline Más forrás:................... & $\odot_{1}$ & ${ }_{2}$ & $\bigodot_{3}$ & $\bigodot_{4}$ & $\odot_{5}$ \\
\hline Más forrás:................... & $\odot_{1}$ & ${ }_{2}$ & $\bigodot_{3}$ & $\bigodot_{4}$ & $\odot_{5}$ \\
\hline Más forrás:................... & $\Theta_{1}$ & $\begin{array}{c}\odot \\
2\end{array}$ & $\Theta_{3}$ & $\bigodot_{4}$ & $\odot_{5}$ \\
\hline
\end{tabular}

K3b. Mennyire bízik meg az adott információforrásokban környezetvédelmi kérdésekben?

Kérjüik, válaszát egy ötfokú skála segítségével adja meg, ahol az 1-es "egyáltalán nem", az 5-ös pedig "teljes mértékben" értelemben szerepel!

\begin{tabular}{|c|c|c|c|c|c|}
\hline & $\begin{array}{l}\text { 1- egyáltalán } \\
\text { nem }\end{array}$ & 2 & 3 & 4 & $\begin{array}{l}\text { 5- teljes } \\
\text { mértékben }\end{array}$ \\
\hline Újságok & $\odot_{1}$ & $\begin{array}{c}\odot \\
2\end{array}$ & $\begin{array}{c}\odot \\
3\end{array}$ & $\begin{array}{c}\odot \\
4\end{array}$ & $\odot_{5}$ \\
\hline Folyóiratok & $\odot_{1}$ & $\odot$ & $\odot$ & $\odot$ & $\odot_{5}$ \\
\hline Televíziós hírek & $\odot_{1}$ & $\begin{array}{c}\odot \\
2\end{array}$ & $\begin{array}{c}\odot \\
3\end{array}$ & $\begin{array}{c}\odot \\
4\end{array}$ & $\odot_{5}$ \\
\hline Rádió & $\odot_{1}$ & $\begin{array}{c}\odot \\
2\end{array}$ & $\begin{array}{c}\odot \\
3\end{array}$ & $\begin{array}{c}\odot \\
4\end{array}$ & $\odot_{5}$ \\
\hline $\begin{array}{l}\text { Filmek és dokumentum müsorok a TV- } \\
\text { ben }\end{array}$ & $\odot_{1}$ & $\begin{array}{c}\odot \\
2\end{array}$ & $\begin{array}{c}\odot \\
3\end{array}$ & $\begin{array}{c}\odot \\
4\end{array}$ & $\odot_{5}$ \\
\hline $\begin{array}{l}\text { Beszélgetések rokonokkal, } \\
\text { családtagokkal }\end{array}$ & $\odot_{1}$ & $\begin{array}{c}\odot \\
2\end{array}$ & $\odot$ & 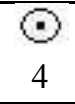 & $\odot_{5}$ \\
\hline $\begin{array}{l}\text { Beszélgetések barátokkal, } \\
\text { szomszédokkal, kollégákkal }\end{array}$ & $\odot_{1}$ & $\begin{array}{c}\odot \\
2\end{array}$ & $\begin{array}{c}\odot \\
3\end{array}$ & $\begin{array}{c}\odot \\
4\end{array}$ & $\odot_{5}$ \\
\hline Internetes oldalak, cikkek, keresők & $\odot_{1}$ & $\begin{array}{c}\odot \\
2\end{array}$ & $\odot$ & $\odot$ & $\odot_{5}$ \\
\hline Blogok, fórumok, közösségi oldalak & $\odot_{1}$ & $\begin{array}{c}\odot \\
2\end{array}$ & $\begin{array}{c}\odot \\
3\end{array}$ & $\begin{array}{c}\odot \\
4\end{array}$ & $\odot_{5}$ \\
\hline Könyvek & $\odot_{1}$ & $\begin{array}{c}\odot \\
2\end{array}$ & $\begin{array}{c}\odot \\
3\end{array}$ & $\begin{array}{c}\odot \\
4\end{array}$ & $\odot_{5}$ \\
\hline Szakcikkek, kiadványok, prospektusok & $\odot_{1}$ & $\begin{array}{c}\odot \\
2\end{array}$ & $\begin{array}{c}\odot \\
3\end{array}$ & $\bigodot_{4}$ & $\odot_{5}$ \\
\hline $\begin{array}{l}\text { Konferenciák, kiállítások, vásárok, } \\
\text { fesztiválok }\end{array}$ & $\odot_{1}$ & $\begin{array}{c}\odot \\
2\end{array}$ & $\begin{array}{c}\odot \\
3\end{array}$ & $\begin{array}{c}\odot \\
4\end{array}$ & $\odot_{5}$ \\
\hline $\begin{array}{l}\text { Civil szervezetek kiadványai, } \\
\text { rendezvényei }\end{array}$ & $\odot_{1}$ & $\begin{array}{c}\odot \\
2\end{array}$ & $\begin{array}{c}\odot \\
3\end{array}$ & $\begin{array}{c}\odot \\
4\end{array}$ & $\Theta_{5}$ \\
\hline Más forrás:................. & $\odot_{1}$ & $\begin{array}{c}\odot \\
2\end{array}$ & $\begin{array}{c}\odot \\
3\end{array}$ & $\begin{array}{c}\odot \\
4\end{array}$ & $\odot_{5}$ \\
\hline Más forrás:................ & $\odot_{1}$ & $\begin{array}{c}\odot \\
2\end{array}$ & $\begin{array}{c}\odot \\
3\end{array}$ & $\begin{array}{c}\odot \\
4\end{array}$ & $\odot_{5}$ \\
\hline Más forrás:................ & $\odot_{1}$ & $\begin{array}{c}\odot \\
2\end{array}$ & $\begin{array}{c}\odot \\
3\end{array}$ & $\begin{array}{c}\odot \\
4\end{array}$ & $\odot_{5}$ \\
\hline
\end{tabular}


K4a. Millyen gyakran veszi igénybe a következő információforrásokat általában?

Kérjüik, válaszát egy ötfokú skála segítségével adja meg, ahol az 1-es "egyáltalán nem", az 5-ös pedig "rendszeresen" értelemben szerepel!

\begin{tabular}{|c|c|c|c|c|c|}
\hline & $\begin{array}{c}\text { 1- egyáltalán } \\
\text { nem }\end{array}$ & 2 & 3 & 4 & $\begin{array}{c}5- \\
\text { rendszeresen }\end{array}$ \\
\hline Újságok & $\bigodot_{1}$ & $\bigodot_{2}$ & $\bigodot_{3}$ & $\bigodot_{4}$ & $\bigodot_{5}$ \\
\hline Folyóiratok & $\bigodot_{1}$ & $\begin{array}{c}\odot \\
2\end{array}$ & $\begin{array}{c}\odot \\
3\end{array}$ & $\bigodot_{4}$ & $\odot_{5}$ \\
\hline Televíziós hírek & $\bigodot_{1}$ & $\begin{array}{l}\odot \\
2\end{array}$ & $\begin{array}{c}\odot \\
3\end{array}$ & $\bigodot_{4}$ & $\bigodot_{5}$ \\
\hline Rádió & $\bigodot_{1}$ & $\begin{array}{l}\odot \\
2\end{array}$ & $\begin{array}{c}\odot \\
3\end{array}$ & $\bigodot_{4}$ & $\odot_{5}$ \\
\hline $\begin{array}{l}\text { Filmek és dokumentum müsorok a TV- } \\
\text { ben }\end{array}$ & $\bigodot_{1}$ & $\begin{array}{l}\odot \\
2\end{array}$ & $\begin{array}{c}\odot \\
3\end{array}$ & $\bigodot_{4}$ & $\odot_{5}$ \\
\hline $\begin{array}{l}\text { Beszélgetések rokonokkal, } \\
\text { családtagokkal }\end{array}$ & $\bigodot_{1}$ & $\begin{array}{c}\odot \\
2\end{array}$ & $\odot_{3}^{\odot}$ & $\odot_{4}$ & $\odot_{5}$ \\
\hline $\begin{array}{l}\text { Beszélgetések barátokkal, } \\
\text { szomszédokkal, kollégákkal }\end{array}$ & $\odot_{1}$ & $\begin{array}{c}\odot \\
2\end{array}$ & $\bigodot_{3}$ & $\bigodot_{4}$ & $\odot_{5}$ \\
\hline Internetes oldalak, cikkek, keresők & $\odot_{1}$ & $\begin{array}{l}\odot \\
2\end{array}$ & $\begin{array}{c}\odot \\
3\end{array}$ & $\bigodot_{4}$ & $\odot_{5}$ \\
\hline Blogok, fórumok, közösségi oldalak & $\odot_{1}$ & $\begin{array}{c}\odot \\
2\end{array}$ & $\bigodot_{3}$ & $\begin{array}{c}\odot \\
4\end{array}$ & $\Theta_{5}$ \\
\hline Könyvek & $\bigodot_{1}$ & $\begin{array}{c}\odot \\
2\end{array}$ & $\begin{array}{c}\odot \\
3\end{array}$ & $\odot$ & $\odot_{5}$ \\
\hline Szakcikkek, kiadványok, prospektusok & $\odot_{1}$ & $\begin{array}{l}\odot \\
2\end{array}$ & $\begin{array}{c}\odot \\
3\end{array}$ & $\begin{array}{c}\odot \\
4\end{array}$ & $\bigodot_{5}$ \\
\hline $\begin{array}{l}\text { Konferenciák, kiállítások, vásárok, } \\
\text { fesztiválok }\end{array}$ & $\odot_{1}$ & $\begin{array}{l}\odot \\
2\end{array}$ & $\begin{array}{c}\odot \\
3\end{array}$ & $\bigodot_{4}$ & $\odot_{5}$ \\
\hline $\begin{array}{l}\text { Civil szervezetek kiadványai, } \\
\text { rendezvényei }\end{array}$ & $\bigodot_{1}$ & $\begin{array}{c}\odot \\
2\end{array}$ & $\begin{array}{c}\odot \\
3\end{array}$ & $\begin{array}{c}\odot \\
4\end{array}$ & $\odot_{5}$ \\
\hline Más forrás:................. & $\odot_{1}$ & $\begin{array}{l}\odot \\
2\end{array}$ & $\begin{array}{c}\odot \\
3\end{array}$ & $\begin{array}{c}\odot \\
4\end{array}$ & $\odot_{5}$ \\
\hline Más forrás:................. & $\odot_{1}$ & $\begin{array}{l}\odot \\
2\end{array}$ & $\begin{array}{c}\odot \\
3\end{array}$ & $\begin{array}{c}\odot \\
4\end{array}$ & $\odot_{5}$ \\
\hline Más forrás:................ & $\odot_{1}$ & $\begin{array}{c}\odot \\
2\end{array}$ & $\begin{array}{c}\odot \\
3\end{array}$ & $\begin{array}{c}\odot \\
4\end{array}$ & $\odot_{5}$ \\
\hline
\end{tabular}

K4b. Mennyire bízik meg az adott információforrásokban?

Kérjüik, válaszát egy ötfokú skála segítségével adja meg, ahol az 1-es "egyáltalán nem", az 5-ös pedig "teljes mértékben" értelemben szerepel!

\begin{tabular}{|l|c|c|c|c|c|}
\hline & $\begin{array}{c}\text { 1- egyáltalán } \\
\text { nem }\end{array}$ & 2 & 3 & 4 & $\begin{array}{c}5-\text { teljes } \\
\text { mértékben }\end{array}$ \\
\hline Újságok & $\bigodot_{1}$ & $\odot$ & $\odot$ & $\odot$ & $\odot_{5}$ \\
\hline
\end{tabular}




\begin{tabular}{|c|c|c|c|c|c|}
\hline Folyóiratok & $\odot_{1}$ & $\begin{array}{c}\odot \\
2\end{array}$ & $\odot$ & $\begin{array}{c}\odot \\
4\end{array}$ & $\odot_{5}$ \\
\hline Televíziós hírek & $\odot_{1}$ & $\begin{array}{c}\odot \\
2\end{array}$ & $\odot$ & $\begin{array}{c}\odot \\
4\end{array}$ & $\odot_{5}$ \\
\hline Rádió & $\bigodot_{1}$ & $\begin{array}{c}\odot \\
2\end{array}$ & $\odot$ & $\begin{array}{c}\odot \\
4\end{array}$ & $\Theta_{5}$ \\
\hline $\begin{array}{l}\text { Filmek és dokumentum müsorok a TV- } \\
\text { ben }\end{array}$ & $\odot_{1}$ & $\begin{array}{c}\odot \\
2\end{array}$ & $\odot$ & $\odot$ & $\odot_{5}$ \\
\hline $\begin{array}{l}\text { Beszélgetések rokonokkal, } \\
\text { családtagokkal }\end{array}$ & $\odot_{1}$ & $\begin{array}{c}\odot \\
2\end{array}$ & $\odot$ & $\begin{array}{c}\odot \\
4\end{array}$ & $\bigodot_{5}$ \\
\hline $\begin{array}{l}\text { Beszélgetések barátokkal, } \\
\text { szomszédokkal, kollégákkal }\end{array}$ & $\odot_{1}$ & $\begin{array}{c}\odot \\
2\end{array}$ & $\odot$ & $\begin{array}{c}Q \\
4\end{array}$ & $\odot_{5}$ \\
\hline Internetes oldalak, cikkek, keresők & $\odot_{1}$ & $\begin{array}{c}\odot \\
2\end{array}$ & $\begin{array}{c}\odot \\
3\end{array}$ & $\begin{array}{c}\odot \\
4\end{array}$ & $\odot_{5}$ \\
\hline Blogok, fórumok, közösségi oldalak & $\bigodot_{1}$ & $\begin{array}{c}\odot \\
2\end{array}$ & $\bigodot_{3}$ & $\begin{array}{c}\odot \\
4\end{array}$ & $\odot_{5}$ \\
\hline Könyvek & $\odot_{1}$ & $\begin{array}{c}\odot \\
2\end{array}$ & 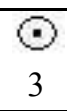 & $\begin{array}{c}9 \\
4\end{array}$ & $\odot_{5}$ \\
\hline Szakcikkek, kiadványok, prospektusok & $\odot_{1}$ & $\begin{array}{c}\odot \\
2\end{array}$ & $\odot$ & $\begin{array}{c}\odot \\
4\end{array}$ & $\odot_{5}$ \\
\hline $\begin{array}{l}\text { Konferenciák, kiállítások, vásárok, } \\
\text { fesztiválok }\end{array}$ & $\odot_{1}$ & $\begin{array}{c}\odot \\
2\end{array}$ & $\odot$ & $\begin{array}{c}\odot \\
4\end{array}$ & $\bigodot_{5}$ \\
\hline $\begin{array}{l}\text { Civil szervezetek kiadványai, } \\
\text { rendezvényei }\end{array}$ & $\odot_{1}$ & $\begin{array}{c}\odot \\
2\end{array}$ & $\odot$ & $\begin{array}{c}\odot \\
4\end{array}$ & $\Theta_{5}$ \\
\hline Más forrás:................ & $\odot_{1}$ & $\begin{array}{c}\odot \\
2\end{array}$ & $\odot$ & $\begin{array}{c}\odot \\
4\end{array}$ & $\odot_{5}$ \\
\hline Más forrás:................. & $\odot_{1}$ & $\begin{array}{c}\odot \\
2\end{array}$ & $\odot$ & $\underset{4}{\odot}$ & $\Theta_{5}$ \\
\hline Más forrás:................. & $\odot_{1}$ & $\begin{array}{c}\odot \\
2\end{array}$ & $\odot$ & $\begin{array}{c}\odot \\
4\end{array}$ & $\odot_{5}$ \\
\hline
\end{tabular}

K4a_1. A következő állításoknál kérjük, válassza ki, hogy milyen gyakran jellemzö Önre az adott viselkedés!

Válassza a „Nem vonatkozik rám” lehetőséget, amennyiben nem tud választ adni! (PI. az autóvezetéssel kapcsolatos kérdéseknél, ha nincs jogosítványa.)

\begin{tabular}{|c|c|c|c|c|c|c|}
\hline & Soha & Ritkán & Alkalmanként & Gyakran & Mindig & $\begin{array}{c}\text { Nem } \\
\text { vonatkozik } \\
\text { rám }\end{array}$ \\
\hline $\begin{array}{l}\text { Biciklivel vagy } \\
\text { tömegközlekedési eszközzel } \\
\text { megyek munkába, iskolába. }\end{array}$ & $\odot$ & $\odot_{2}$ & $\Theta_{3}$ & $\odot_{4}$ & $\Theta_{5}$ & $\odot_{6}$ \\
\hline $\begin{array}{l}\text { Olyan húst vagy egyéb } \\
\text { termékeket veszek, } \\
\text { amelyeken öko címke van. }\end{array}$ & $\odot$ & $\odot_{2}$ & $\odot_{3}$ & $\odot_{4}$ & $\Theta_{5}$ & $\odot_{6}$ \\
\hline $\begin{array}{l}\text { Inkább zuhanyozni szoktam, } \\
\text { mint kádban fürdeni. }\end{array}$ & $\odot$ & $\odot_{2}$ & $\odot_{3}$ & $\odot_{4}$ & $\odot_{5}$ & $\odot_{6}$ \\
\hline
\end{tabular}




\begin{tabular}{|c|c|c|c|c|c|c|}
\hline $\begin{array}{l}\text { Szoktam fémdobozos } \\
\text { italokat venni. }\end{array}$ & $\begin{array}{c}\odot \\
1\end{array}$ & $\odot_{2}$ & $\odot_{3}$ & $\Theta_{4}$ & $\odot_{5}$ & $\odot_{6}$ \\
\hline $\begin{array}{l}\text { A sütőm tisztításához } \\
\text { sütőtisztító sprayt } \\
\text { használok. }\end{array}$ & $\odot$ & $\odot_{2}$ & $\odot_{3}$ & $\Theta_{4}$ & $\odot_{5}$ & $\odot_{6}$ \\
\hline $\begin{array}{l}\text { Hazai fából készült fabútort } \\
\text { veszek. }\end{array}$ & $\begin{array}{c}\odot \\
1\end{array}$ & $\Theta_{2}$ & $\odot_{3}$ & $\Theta_{4}$ & $\odot_{5}$ & $\Theta_{6}$ \\
\hline $\begin{array}{l}\text { Csak akkor mosok, ha már } \\
\text { összegyült egy teljes } \\
\text { mosásnyi szennyes. }\end{array}$ & $\begin{array}{c}\odot \\
1\end{array}$ & $\Theta_{2}$ & $\odot_{3}$ & $\odot_{4}$ & $\odot_{5}$ & $\odot_{6}$ \\
\hline $\begin{array}{l}\text { Szoktam autóval a városban } \\
\text { közlekedni. }\end{array}$ & $\begin{array}{c}\odot \\
1\end{array}$ & $\odot_{2}$ & $\odot_{3}$ & $\Theta_{4}$ & $\bigodot_{5}$ & $\odot_{6}$ \\
\hline $\begin{array}{l}\text { Télen hosszasan nyitva } \\
\text { tartom az ablakot, hogy jó } \\
\text { friss levegő legyen a } \\
\text { szobában. }\end{array}$ & $\odot$ & $\odot_{2}$ & $\odot_{3}$ & $\odot_{4}$ & $\odot_{5}$ & $\odot_{6}$ \\
\hline $\begin{array}{l}\text { A koszos ruhákat előmosás } \\
\text { nélkül szoktam mosni. }\end{array}$ & $\begin{array}{c}\odot \\
1\end{array}$ & $\odot_{2}$ & $\odot_{3}$ & $\odot_{4}$ & $\odot_{5}$ & $\odot_{6}$ \\
\hline
\end{tabular}

K4a_2. A következő álításoknál kérjük, válassza ki, hogy milyen gyakran jellemzö Önre az adott viselkedés!

Válassza a „Nem vonatkozik rám" lehetőséget, amennyiben nem tud választ adni! (Pl. az autóvezetéssel kapcsolatos kérdéseknél, ha nincs jogosítványa.)

\begin{tabular}{|c|c|c|c|c|c|c|}
\hline & Soha & Ritkán & Alkalmanként & Gyakran & Mindig & $\begin{array}{c}\text { Nem } \\
\text { vonatkozik } \\
\text { rám }\end{array}$ \\
\hline $\begin{array}{l}\text { Autópályán } 100 \mathrm{~km} / \text { óra alatti } \\
\text { sebességgel szoktam vezetni. }\end{array}$ & $\odot$ & $\odot_{2}$ & $\Theta_{3}$ & $\odot_{4}$ & $\odot_{5}$ & $\odot_{6}$ \\
\hline $\begin{array}{l}\text { A hat óránál hosszabb utakra } \\
\text { repülővel szoktam menni. }\end{array}$ & $\begin{array}{c}\odot \\
1\end{array}$ & $\odot_{2}$ & $\odot_{3}$ & $\odot_{4}$ & $\odot_{5}$ & $\odot_{6}$ \\
\hline $\begin{array}{l}\text { Ha egy boltban múanyag } \\
\text { szatyrot adnak, azt mindig } \\
\text { elfogadom. }\end{array}$ & $\odot$ & $\odot_{2}$ & $\odot_{3}$ & $\odot_{4}$ & $\odot_{5}$ & $\odot_{6}$ \\
\hline $\begin{array}{l}\text { A közeli területekre ( } 30 \text { km- } \\
\text { en belül) tömegközlekedési } \\
\text { eszközzel vagy biciklivel } \\
\text { megyek. }\end{array}$ & 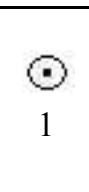 & $\odot_{2}$ & $\odot_{3}$ & $\odot_{4}$ & $\bigodot_{5}$ & $\Theta_{6}$ \\
\hline $\begin{array}{l}\text { Összegyújtöm a használt } \\
\text { papírt és elviszem egy } \\
\text { szelektív hulladékgyüjtőbe. }\end{array}$ & $\odot$ & $\odot_{2}$ & $\odot_{3}$ & $\odot_{4}$ & $\odot_{5}$ & $\odot_{6}$ \\
\hline $\begin{array}{l}\text { Az üres üvegeket elviszem } \\
\text { egy szelektív hulladékgyüjtő } \\
\text { konténerbe. }\end{array}$ & $\odot$ & $\odot_{2}$ & $\Theta_{3}$ & $\odot_{4}$ & $\bigodot_{5}$ & $\Theta_{6}$ \\
\hline $\begin{array}{l}\text { Elöfordult már, hogy } \\
\text { valakinek felhívtam a } \\
\text { figyelmét arra, hogy } \\
\text { környezetszennyező módon } \\
\text { cselekszik. }\end{array}$ & $\odot$ & $\odot_{2}$ & $\Theta_{3}$ & $\Theta_{4}$ & $\odot_{5}$ & $\Theta_{6}$ \\
\hline
\end{tabular}




\begin{tabular}{|c|c|c|c|c|c|c|}
\hline $\begin{array}{l}\text { Anyagilag is szoktam } \\
\text { támogatni a környezetvédő } \\
\text { szervezeteket. }\end{array}$ & $\odot$ & $\odot_{2}$ & $\odot_{3}$ & $\odot_{4}$ & $\odot_{5}$ & $\odot_{6}$ \\
\hline $\begin{array}{l}\text { A tejet visszaváltható } \\
\text { palackban veszem. }\end{array}$ & $\begin{array}{c}\odot \\
1\end{array}$ & $\Theta_{2}$ & $\odot_{3}$ & $\odot_{4}$ & $\odot_{5}$ & $\odot_{6}$ \\
\hline $\begin{array}{l}\text { Fehérített vagy színezett WC } \\
\text { papírt veszek. }\end{array}$ & $\begin{array}{c}\odot \\
1\end{array}$ & $\Theta_{2}$ & $\odot_{3}$ & $\odot_{4}$ & $\odot_{5}$ & $\odot_{6}$ \\
\hline $\begin{array}{l}\text { Szoktam félkész } \\
\text { élelmiszeripari termékeket } \\
\text { venni. }\end{array}$ & $\odot$ & $\Theta_{2}$ & $\odot_{3}$ & $\odot_{4}$ & $\bigodot_{5}$ & $\odot_{6}$ \\
\hline
\end{tabular}

K4a_3. A következö állításoknál kérjük, válassza ki, hogy milyen gyakran jellemzö Önre az adott viselkedés!

Válassza a „Nem vonatkozik rám" lehetőséget, amennyiben nem tud választ adni! (Pl. az autóvezetéssel kapcsolatos kérdéseknél, ha nincs jogosítványa.)

\begin{tabular}{|c|c|c|c|c|c|c|}
\hline & Soha & Ritkán & Alkalmanként & Gyakran & Mindig & $\begin{array}{c}\text { Nem } \\
\text { vonatkozik } \\
\text { rám }\end{array}$ \\
\hline $\begin{array}{l}\text { Olyan termékeket vásárolok, } \\
\text { amelyeknek utántöltős a } \\
\text { csomagolása. }\end{array}$ & $\odot$ & $\odot_{2}$ & $\odot_{3}$ & $\Theta_{4}$ & $\odot_{5}$ & $\odot_{6}$ \\
\hline $\begin{array}{l}\text { Bojkottálom a } \\
\text { környezetszennyező } \\
\text { vállalatokat. }\end{array}$ & $\odot$ & $\odot_{2}$ & $\Theta_{3}$ & $\Theta_{4}$ & $\odot_{5}$ & $\Theta_{6}$ \\
\hline $\begin{array}{l}\text { Szezonális termékeket } \\
\text { vásárolok. }\end{array}$ & $\odot$ & $\odot_{2}$ & $\odot_{3}$ & $\odot_{4}$ & $\odot_{5}$ & $\odot_{6}$ \\
\hline $\begin{array}{l}\text { Elektromos ruhaszárító } \\
\text { gépet használok. }\end{array}$ & $\odot$ & $\odot_{2}$ & $\odot_{3}$ & $\odot_{4}$ & $\odot_{5}$ & $\odot_{6}$ \\
\hline $\begin{array}{l}\text { Szoktam környezetvédelmi } \\
\text { témákról olvasni. }\end{array}$ & $\odot$ & $\odot_{2}$ & $\odot_{3}$ & $\odot_{4}$ & $\odot_{5}$ & $\odot_{6}$ \\
\hline $\begin{array}{l}\text { A barátaimmal szoktunk } \\
\text { környezetvédelmet érintő } \\
\text { témákról beszélgetni. }\end{array}$ & 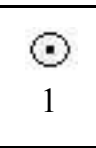 & $\odot_{2}$ & $\odot_{3}$ & $\odot_{4}$ & $\odot_{5}$ & $\odot_{6}$ \\
\hline $\begin{array}{l}\text { Járatom a motort, miközben } \\
\text { vasúti átjárónál vagy } \\
\text { dugóban várakozom. }\end{array}$ & $\odot$ & $\odot_{2}$ & $\odot_{3}$ & $\odot_{4}$ & $\odot_{5}$ & $\Theta_{6}$ \\
\hline $\begin{array}{l}\text { Piros lámpánál várakozva } \\
\text { járatom a motort. }\end{array}$ & $\odot$ & $\Theta_{2}$ & $\odot_{3}$ & $\Theta_{4}$ & $\odot_{5}$ & $\odot_{6}$ \\
\hline $\begin{array}{l}\text { Vegyi rovarölő szerrel } \\
\text { pusztítom el a rovarokat. }\end{array}$ & $\begin{array}{c}\odot \\
1\end{array}$ & $\odot_{2}$ & $\odot_{3}$ & $\odot_{4}$ & $\odot_{5}$ & $\odot_{6}$ \\
\hline $\begin{array}{l}\text { Télen, ha négy óránál } \\
\text { hosszabb időre megyek el a } \\
\text { lakásból, leveszem a fütést. }\end{array}$ & $\odot$ & $\odot_{2}$ & $\odot_{3}$ & $\Theta_{4}$ & $\odot_{5}$ & $\Theta_{6}$ \\
\hline $\begin{array}{l}\text { Autóval megyek addig, } \\
\text { ahonnan túrázni indulok. }\end{array}$ & $\odot$ & $\Theta_{2}$ & $\odot_{3}$ & $\Theta_{4}$ & $\odot_{5}$ & $\odot_{6}$ \\
\hline
\end{tabular}


K4b_1. A következő állításoknál kérjük, jelölje, hogy igaz-e Önre az adott állítás vagy sem! Válassza a „Nem vonatkozik rám” válaszlehetőséget, ha nem tud válaszolni!

\begin{tabular}{|c|c|c|c|}
\hline & igen & nem & $\begin{array}{l}\text { Nem vonatkozik } \\
\text { rám }\end{array}$ \\
\hline Gyakran használom a bevásárló táskáimat. & $\left(\begin{array}{c}0 \\
1\end{array}\right.$ & $\begin{array}{c}0 \\
2\end{array}$ & $\Theta_{3}$ \\
\hline $\begin{array}{l}\text { Télen felcsavarom a fütést, hogy ne kelljen pulóvert } \\
\text { vennem. }\end{array}$ & $\left(\begin{array}{c}0 \\
1\end{array}\right.$ & $\underset{2}{Q}$ & $O_{3}$ \\
\hline Használok öblítőt a mosáshoz. & $\begin{array}{c}0 \\
1\end{array}$ & $(9$ & $\Theta$ \\
\hline A lemerült elemeket a szemétbe dobom. & $\begin{array}{c}0 \\
1\end{array}$ & $\left(\begin{array}{c}Q \\
2\end{array}\right.$ & $\Theta_{3}$ \\
\hline Étkezés után az ételmaradékokat a WC-be borítom. & $\left(\begin{array}{c}0 \\
1\end{array}\right.$ & Q & $\Theta_{3}$ \\
\hline A fürdőszobában légfrissítő spray-t használok. & $(9$ & $\begin{array}{c}0 \\
2\end{array}$ & $\Theta_{3}$ \\
\hline Tagja vagyok valamelyik környezetvédő szervezetnek. & $\left(\begin{array}{c}0 \\
1\end{array}\right.$ & $(9$ & $\Theta_{3}$ \\
\hline Amikor hotelben vagyok, naponta cseréltetem a törölközőt. & $\left(\begin{array}{c}0 \\
1\end{array}\right.$ & $\begin{array}{c}0 \\
2\end{array}$ & $\Theta_{3}$ \\
\hline Energiatakarékos háztartási gépeim vannak. & $\underset{1}{(}$ & $\begin{array}{c}0 \\
2\end{array}$ & $\Theta_{3}$ \\
\hline
\end{tabular}

K4b_2. A következő állításoknál kérjük jelölje, hogy igaz-e Önre az adott állítás vagy sem! Válassza a „Nem vonatkozik rám" válaszlehetőséget, ha nem tud válaszolni!

\begin{tabular}{|c|c|c|c|}
\hline & igen & nem & $\begin{array}{l}\text { Nem vonatkozik } \\
\text { rám }\end{array}$ \\
\hline $\begin{array}{l}\text { Amikor piknikezek, ugyanolyan tisztán hagyom a terepet } \\
\text { magam után, mint amilyen volt. }\end{array}$ & 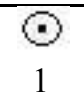 & $(9$ & $O_{3}$ \\
\hline Napelemeket vettem, hogy energiát állítsak elő. & 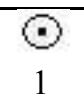 & $(9$ & $\bigcirc_{3}$ \\
\hline $\begin{array}{l}\text { Fontolgattam a saját napelem felszerelésének előnyeit és } \\
\text { hátrányait. }\end{array}$ & $\begin{array}{c}\odot \\
1\end{array}$ & $\begin{array}{c}0 \\
2\end{array}$ & $Q_{3}$ \\
\hline Kértem árajánlatot napelem felszerelésére. & 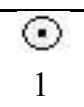 & $\left(\begin{array}{c}0 \\
2\end{array}\right.$ & $\Theta$ \\
\hline Megújuló energiaforrásokat használok. & 0 & $(9$ & $\odot_{3}$ \\
\hline Nincs autóm. & $\left(\begin{array}{c}0 \\
1\end{array}\right.$ & $(9$ & $\Theta_{3}$ \\
\hline Közösen használunk egy autót többen. & $(9$ & $(9$ & $\Theta_{3}$ \\
\hline $\begin{array}{l}\text { Úgy vezetek, hogy az üzemanyag fogyasztásom a lehető } \\
\text { legkevesebb legyen. }\end{array}$ & $\left(\begin{array}{c}0 \\
1\end{array}\right.$ & $\left(\begin{array}{c}0 \\
2\end{array}\right.$ & $Q_{3}$ \\
\hline Az autóm üzemanyag-hatékony (kevesebb, mint 7 liter/100km). & 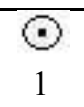 & $\left(\begin{array}{l}0 \\
2\end{array}\right.$ & $\Theta_{3}$ \\
\hline
\end{tabular}




\section{K6. A következő kérdésekre nincsenek jó vagy rossz válaszok.}

Arra vagyunk kíváncsiak, hogy Ön hogyan érez, illetve mi a véleménye az alábbi állításokkal kapcsolatban.

Kérjük, válaszát egy ötfokú skála segítségével adja meg, ahol az 1-es "egyáltalán nem értek egyet", az 5-ös pedig "teljes mértékben egyetértek" értelemben szerepel!

\begin{tabular}{|c|c|c|c|c|c|}
\hline & $\begin{array}{l}\text { 1- egyáltalán } \\
\text { nem értek } \\
\text { egyet }\end{array}$ & 2 & 3 & 4 & $\begin{array}{l}\text { 5- teljes } \\
\text { mértékben } \\
\text { egyetértek }\end{array}$ \\
\hline $\begin{array}{l}\text { A népesség száma kezdi elérni azt a } \\
\text { mértéket, amit a Föld még képes ellátni. }\end{array}$ & $\odot_{1}$ & $\begin{array}{c}\odot \\
2\end{array}$ & $\begin{array}{c}\odot \\
3\end{array}$ & $\odot$ & $\odot_{5}$ \\
\hline $\begin{array}{l}\text { Az embereknek jogukban áll a természeti } \\
\text { környezetet igényeikhez igazítani. }\end{array}$ & $\bigodot_{1}$ & $\odot$ & $\odot$ & $\odot$ & $\bigodot_{5}$ \\
\hline $\begin{array}{l}\text { Amikor az ember beleavatkozik a } \\
\text { környezetbe, annak gyakran } \\
\text { katasztrofális következményei vannak. }\end{array}$ & $\odot_{1}$ & 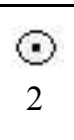 & $\odot$ & $\odot$ & $\odot_{5}$ \\
\hline $\begin{array}{l}\text { Az emberi találékonyság biztosíték arra, } \\
\text { hogy ne tegyük elviselhetetlenné a földi } \\
\text { életet. }\end{array}$ & $\bigodot_{1}$ & $\begin{array}{c}\odot \\
2\end{array}$ & $\begin{array}{c}\odot \\
3\end{array}$ & $\odot$ & $\odot_{5}$ \\
\hline $\begin{array}{l}\text { Az emberek túlzott mértékben rongálják } \\
\text { a környezetet. }\end{array}$ & $\odot_{1}$ & $\begin{array}{c}\odot \\
2\end{array}$ & $\begin{array}{c}\odot \\
3\end{array}$ & $\odot$ & $\odot_{5}$ \\
\hline $\begin{array}{l}\text { A Föld rengeteg természeti erőforrással } \\
\text { rendelkezik, csak meg kell tanulnunk } \\
\text { kiaknázni őket. }\end{array}$ & $\bigodot_{1}$ & $\begin{array}{c}\odot \\
2\end{array}$ & $\odot$ & $\odot$ & $\odot_{5}$ \\
\hline $\begin{array}{l}\text { A növényeknek és állatoknak épp annyi } \\
\text { joguk van az élethez, mint az } \\
\text { embereknek. }\end{array}$ & $\odot_{1}$ & $\odot$ & $\odot$ & $\odot$ & $\odot_{5}$ \\
\hline $\begin{array}{l}\text { A természet egyensúlya elég stabil } \\
\text { ahhoz, hogy megbirkózzon a modern } \\
\text { ipari nemzetek okozta hatásokkal. }\end{array}$ & $\odot_{1}$ & $\begin{array}{c}\odot \\
2\end{array}$ & $\odot$ & $\bigodot_{4}$ & $\Theta_{5}$ \\
\hline $\begin{array}{l}\text { Különleges képességeik ellenére az } \\
\text { emberek még mindig alá vannak } \\
\text { rendelve a természet törvényeinek. }\end{array}$ & $\odot_{1}$ & $\begin{array}{c}\odot \\
2\end{array}$ & $\underset{3}{\odot}$ & $\odot$ & $\odot_{5}$ \\
\hline $\begin{array}{l}\text { Az emberiséget fenyegető úgynevezett } \\
\text { "ökológiai válság" túlzottan felnagyított. }\end{array}$ & $\odot_{1}$ & $\begin{array}{c}\odot \\
2\end{array}$ & $\begin{array}{c}\odot \\
3\end{array}$ & $\odot$ & $\odot_{5}$ \\
\hline $\begin{array}{l}\text { A Föld olyan, mint egy úrhajó, amelyen } \\
\text { mind a hely, mind pedig az erőforrások } \\
\text { korlátozottak. }\end{array}$ & $\odot_{1}$ & $\underset{2}{\odot}$ & $\odot$ & $\odot$ & $\odot_{5}$ \\
\hline $\begin{array}{l}\text { Az emberek a természet feletti } \\
\text { uralkodásra hívatottak. }\end{array}$ & $\odot_{1}$ & $\begin{array}{c}\odot \\
2\end{array}$ & $\begin{array}{c}\odot \\
3\end{array}$ & $\begin{array}{c}\odot \\
4\end{array}$ & $\odot_{5}$ \\
\hline $\begin{array}{l}\text { A természeti egyensúly nagyon kényes } \\
\text { és könnyen felborítható. }\end{array}$ & $\bigodot_{1}$ & $\begin{array}{c}\odot \\
2\end{array}$ & $\begin{array}{c}\odot \\
3\end{array}$ & $\begin{array}{c}\odot \\
4\end{array}$ & $\bigodot_{5}$ \\
\hline $\begin{array}{l}\text { Az emberek eleget fognak tudni a } \\
\text { természet működéséről, ahhoz, hogy } \\
\text { irányítani tudják. }\end{array}$ & $\odot_{1}$ & $\begin{array}{c}\odot \\
2\end{array}$ & $\begin{array}{c}\odot \\
3\end{array}$ & $\odot$ & $\odot_{5}$ \\
\hline $\begin{array}{l}\text { Ha a dolgok ugyanígy folytatódnak } \\
\text { tovább, hamarosan jelentős ökológiai } \\
\text { katasztrófa elé nézünk. }\end{array}$ & $\Theta_{1}$ & $\begin{array}{c}\odot \\
2\end{array}$ & $\underset{3}{\odot}$ & $\underset{4}{-}$ & $\Theta_{5}$ \\
\hline
\end{tabular}


K7. A következőkben az Ön véleményére vagyunk kíváncsiak az alábbi állításokkal kapcsolatban.

Mennyire ért egyet az alábbi állításokkal?

Kérjüik, válaszát egy ötfokú skála segítségével adja meg, ahol az 1-es "egyáltalán nem értek egyet", az 5-ös pedig "teljes mértékben egyetértek" értelemben szerepel!

\begin{tabular}{|c|c|c|c|c|c|}
\hline & $\begin{array}{l}\text { 1- egyáltalán } \\
\text { nem értek } \\
\text { egyet }\end{array}$ & 2 & 3 & 4 & $\begin{array}{l}\text { 5- teljes } \\
\text { mértékben } \\
\text { egyetértek }\end{array}$ \\
\hline $\begin{array}{l}\text { A környezetszennyezés közegészségre } \\
\text { gyakorolt hatása rosszabb az észleltnél. }\end{array}$ & $\odot_{1}$ & $\begin{array}{c}\odot \\
2\end{array}$ & $\begin{array}{c}\odot \\
3\end{array}$ & $\odot$ & $\odot_{5}$ \\
\hline $\begin{array}{l}\text { A környezetvédelem hozzájárul az emberek } \\
\text { életminőségnek javításához. }\end{array}$ & $\Theta_{1}$ & $\begin{array}{c}\odot \\
2\end{array}$ & $\begin{array}{c}\odot \\
3\end{array}$ & $\odot$ & $\bigodot_{5}$ \\
\hline $\begin{array}{l}\text { A helyben okozott környezetszennyezés } \\
\text { világszerte károsítja az embereket. }\end{array}$ & $\odot_{1}$ & $\begin{array}{c}\odot \\
2\end{array}$ & $\begin{array}{c}\odot \\
3\end{array}$ & $\odot$ & $\odot_{5}$ \\
\hline A környezetvédelem mindenkinek hasznos. & $\odot_{1}$ & $\begin{array}{c}\odot \\
2\end{array}$ & $\begin{array}{c}\odot \\
3\end{array}$ & $\odot$ & $\odot_{5}$ \\
\hline $\begin{array}{l}\text { Nem kell túlságosan aggódnunk a környezet } \\
\text { miatt, hiszen a jövő generációi jobban fogják } \\
\text { tudni, mint mi, hogy hogyan kezeljék ezeket } \\
\text { a problémákat. }\end{array}$ & $\odot_{1}$ & $\begin{array}{c}\odot \\
2\end{array}$ & $\odot$ & $\odot$ & $\odot_{5}$ \\
\hline $\begin{array}{l}\text { Eltúlzottak azok az állítások, hogy } \\
\text { megváltoztatjuk a környezetet. }\end{array}$ & $\odot_{1}$ & $\begin{array}{c}\odot \\
2\end{array}$ & $\begin{array}{c}\odot \\
3\end{array}$ & $\odot$ & $\odot_{5}$ \\
\hline $\begin{array}{l}\text { Az elkövetkezö néhány évtizedben több ezer } \\
\text { növény és állatfaj fog kihalni. }\end{array}$ & $\Theta_{1}$ & $\begin{array}{c}\odot \\
2\end{array}$ & $\begin{array}{c}\odot \\
3\end{array}$ & $\odot$ & $\odot_{5}$ \\
\hline $\begin{array}{l}\text { A modern fejlődés veszélyezteti a } \\
\text { vadvilágot. }\end{array}$ & $\bigodot_{1}$ & $\begin{array}{c}\odot \\
2\end{array}$ & $\begin{array}{c}\odot \\
3\end{array}$ & $\odot$ & $\odot_{5}$ \\
\hline $\begin{array}{l}\text { Noha a környezet romlásától károsodott } \\
\text { néhány helyi növény és állat, a teljes világra } \\
\text { mindez csak kis mértékü hatással van. }\end{array}$ & $\odot_{1}$ & $\odot$ & $\begin{array}{c}\odot \\
3\end{array}$ & $\odot$ & $\odot_{5}$ \\
\hline $\begin{array}{l}\text { A környezetvédelem jó hatással van az } \\
\text { egészségemre. }\end{array}$ & $\odot_{1}$ & $\begin{array}{c}\odot \\
2\end{array}$ & $\begin{array}{c}\odot \\
3\end{array}$ & $\odot$ & $\odot_{5}$ \\
\hline $\begin{array}{l}\text { A tisztább környezet jobb pihenési } \\
\text { lehetőségeket biztosít számomra. }\end{array}$ & $\odot_{1}$ & $\begin{array}{c}\odot \\
2\end{array}$ & $\begin{array}{c}\odot \\
3\end{array}$ & $\odot$ & $\odot_{5}$ \\
\hline $\begin{array}{l}\text { A környezetvédelem fenyegeti a hozzám } \\
\text { hasonlók munkahelyét. }\end{array}$ & $\odot_{1}$ & $\begin{array}{c}\odot \\
2\end{array}$ & $\begin{array}{c}\odot \\
3\end{array}$ & $\odot$ & $\odot_{5}$ \\
\hline $\begin{array}{l}\text { A környezetvédelmi törvények korlátozzák } \\
\text { választási lehetőségeimet és személyes } \\
\text { szabadságomat. }\end{array}$ & $\bigodot_{1}$ & $\begin{array}{c}\odot \\
2\end{array}$ & $\odot$ & $\odot$ & $\odot_{5}$ \\
\hline
\end{tabular}


K8. Szembesülve a természetben okozott károk következményeivel az emberek világszerte aggódnak a környezeti problémák miatt. Ez azonban egyénenként eltérhet abban, hogy mely következmények aggasztanak bennünket a legjobban.

Aggódom mindazon környezeti problémák iránt, amelyek hatással lehetmek...

Kérjüik, hogy értékelje a következő állításokat egy hétfokú skála segítségével, ahol az 1-es

"egyáltalán nem jellemzô rám", a 7-es "küllo̊nösen jellemzố rám" értelemben szerepel!

\begin{tabular}{|c|c|c|c|c|c|c|c|}
\hline & $\begin{array}{l}\text { 1- egyáltalán nem } \\
\text { jellemző rám }\end{array}$ & 2 & 3 & 4 & 5 & 6 & $\begin{array}{l}\text { 7- különösen } \\
\text { jellemző rám }\end{array}$ \\
\hline ... a növényekre. & $\odot_{1}$ & $\begin{array}{c}\odot \\
2\end{array}$ & $\bigodot_{3}$ & $\begin{array}{c}\odot \\
4\end{array}$ & $\begin{array}{c}\odot \\
5\end{array}$ & $\begin{array}{c}\odot \\
6\end{array}$ & $\odot_{7}$ \\
\hline ... rám. & $\odot_{1}$ & $\begin{array}{c}\odot \\
2\end{array}$ & $\begin{array}{c}\odot \\
3\end{array}$ & $\begin{array}{c}\odot \\
4\end{array}$ & $\begin{array}{c}\odot \\
5\end{array}$ & $\begin{array}{c}\odot \\
6\end{array}$ & $\odot_{7}$ \\
\hline $\begin{array}{l}\text {... a környezetemben } \\
\text { élö emberekre. }\end{array}$ & $\odot_{1}$ & $\begin{array}{c}\odot \\
2\end{array}$ & $\begin{array}{c}\odot \\
3\end{array}$ & $\begin{array}{c}\odot \\
4\end{array}$ & $\begin{array}{c}\odot \\
5\end{array}$ & $\begin{array}{c}\odot \\
6\end{array}$ & $\Theta_{7}$ \\
\hline ... a tengeri élővilágra. & $\odot_{1}$ & $\begin{array}{c}\odot \\
2\end{array}$ & $\odot_{3}$ & $\bigodot_{4}$ & $\begin{array}{c}\odot \\
5\end{array}$ & $\begin{array}{c}\odot \\
6\end{array}$ & $\Theta_{7}$ \\
\hline ... az életmódomra. & $\odot_{1}$ & $\begin{array}{c}\odot \\
2\end{array}$ & $\begin{array}{c}\odot \\
3\end{array}$ & $\bigodot_{4}$ & $\begin{array}{c}\odot \\
5\end{array}$ & $\begin{array}{c}\odot \\
6\end{array}$ & $\odot_{7}$ \\
\hline ... az emberekre. & $\odot_{1}$ & $\begin{array}{c}\odot \\
2\end{array}$ & $\begin{array}{c}\odot \\
3\end{array}$ & $\bigodot_{4}$ & $\begin{array}{c}\odot \\
5\end{array}$ & $\begin{array}{c}\odot \\
6\end{array}$ & $\Theta_{7}$ \\
\hline ... a madarakra. & $\odot_{1}$ & $\begin{array}{c}\odot \\
2\end{array}$ & $\bigodot_{3}$ & $\begin{array}{c}\odot \\
4\end{array}$ & $\begin{array}{c}\odot \\
5\end{array}$ & $\begin{array}{c}\odot \\
6\end{array}$ & $\odot_{7}$ \\
\hline ... az egészségemre. & $\odot_{1}$ & $\begin{array}{c}\odot \\
2\end{array}$ & $\begin{array}{c}\odot \\
3\end{array}$ & $\begin{array}{c}\odot \\
4\end{array}$ & $\begin{array}{c}\odot \\
5\end{array}$ & $\begin{array}{c}\odot \\
6\end{array}$ & $\odot_{7}$ \\
\hline ... a gyerekekre. & $\odot_{1}$ & $\begin{array}{c}\odot \\
2\end{array}$ & $\begin{array}{c}\odot \\
3\end{array}$ & $\bigodot_{4}$ & $\begin{array}{c}\odot \\
5\end{array}$ & $\begin{array}{c}\odot \\
6\end{array}$ & $\odot_{7}$ \\
\hline ... az állatokra. & $\odot_{1}$ & $\begin{array}{c}\odot \\
2\end{array}$ & $\begin{array}{c}\odot \\
3\end{array}$ & $\begin{array}{c}\odot \\
4\end{array}$ & $\begin{array}{c}\odot \\
5\end{array}$ & $\begin{array}{c}\odot \\
6\end{array}$ & $\odot_{7}$ \\
\hline ... a jövőmre. & $\odot_{1}$ & $\begin{array}{c}\odot \\
2\end{array}$ & $\begin{array}{c}\odot \\
3\end{array}$ & $\begin{array}{c}\odot \\
4\end{array}$ & $\begin{array}{c}\odot \\
5\end{array}$ & $\begin{array}{c}\odot \\
6\end{array}$ & $\odot_{7}$ \\
\hline $\begin{array}{l}\text {... a következö } \\
\text { generációra. }\end{array}$ & $\odot_{1}$ & $\begin{array}{c}\odot \\
2\end{array}$ & $\begin{array}{c}\odot \\
3\end{array}$ & $\begin{array}{c}\odot \\
4\end{array}$ & $\begin{array}{c}\odot \\
5\end{array}$ & $\begin{array}{c}\odot \\
6\end{array}$ & $\Theta_{7}$ \\
\hline
\end{tabular}




\section{K9. Mennyire tükrözik az alábbi állítások az Ön álláspontját?}

Kérjüik, válaszát egy kilencfokú skála segítségével adja meg, ahol az 1-es "egyáltalán nem értek egyet", a 9-es pedig "teljes mértékben egyetértek" értelemben szerepel!

\begin{tabular}{|c|c|c|c|c|c|c|c|c|c|}
\hline & $\begin{array}{c}1- \\
\text { egyáltalán } \\
\text { nem értek } \\
\text { egyet }\end{array}$ & 2 & 3 & 4 & 5 & 6 & 7 & 8 & $\begin{array}{l}\text { 9- teljes } \\
\text { mértékben } \\
\text { egyetértek }\end{array}$ \\
\hline $\begin{array}{l}\text { Hajlandó vagyok } \\
\text { feladni azokat az } \\
\text { általam kedvelt } \\
\text { tevékenységeket, } \\
\text { amelyeket károsítják a } \\
\text { környezetet. }\end{array}$ & $\bigodot_{1}$ & $\Theta_{2}$ & $\Theta_{3}$ & $\Theta_{4}$ & $\underset{5}{\odot}$ & $\odot$ & $\bigodot_{7}$ & $\begin{array}{c}\odot \\
8\end{array}$ & $\odot_{9}$ \\
\hline $\begin{array}{l}\text { Hajlandó vagyok } \\
\text { olyan } \\
\text { kötelezettségeket } \\
\text { vállalni, amelyek } \\
\text { segítenek a természeti } \\
\text { környezet } \\
\text { megóvásában. }\end{array}$ & $\bigodot_{1}$ & $\begin{array}{c}\odot \\
2\end{array}$ & $\Theta_{3}$ & $\Theta_{4}$ & $\underset{5}{\odot}$ & $\Theta_{6}$ & $\bigodot_{7}$ & $\underset{8}{\odot}$ & $\odot_{9}$ \\
\hline $\begin{array}{l}\text { Hajlandó vagyok } \\
\text { akkor is megtenni } \\
\text { dolgokat a } \\
\text { környezetért, ha senki } \\
\text { sem köszöni meg az } \\
\text { eröfeszítéseimet. }\end{array}$ & $\odot_{1}$ & $\begin{array}{c}\odot \\
2\end{array}$ & $\Theta_{3}$ & $\Theta_{4}$ & $\underset{5}{\Theta}$ & $\Theta_{6}$ & $\underset{7}{\Theta}$ & $\begin{array}{c}\odot \\
8\end{array}$ & $\odot_{9}$ \\
\hline $\begin{array}{l}\text { Akkor is hajlandó } \\
\text { vagyok megtenni azt, } \\
\text { ami a környezetnek a } \\
\text { legjobb, ha az } \\
\text { kényelmetlen } \\
\text { számomra. }\end{array}$ & $\bigodot_{1}$ & $\Theta_{2}$ & $\Theta_{3}$ & $\Theta_{4}$ & $\underset{5}{\odot}$ & $\odot$ & $\underset{7}{\odot}$ & $\begin{array}{c}\odot \\
8\end{array}$ & $\odot_{9}$ \\
\hline $\begin{array}{l}\text { Hajlandó vagyok } \\
\text { rendkívüli } \\
\text { eröfeszítéseket tenni } \\
\text { azért, hogy a } \\
\text { környezetnek a } \\
\text { legjobbat tehessem. }\end{array}$ & $\bigodot_{1}$ & $\begin{array}{c}\odot \\
2\end{array}$ & $\Theta_{3}$ & $\Theta_{4}$ & $\underset{5}{\odot}$ & $\odot$ & $\underset{7}{\Theta}$ & $\begin{array}{c}\odot \\
8\end{array}$ & $\odot_{9}$ \\
\hline
\end{tabular}




\section{K15. A következőkben kérjük, jelölje, hogy mennyire igazalk Önre az alábbi állítások!}

Kérjük, válaszát egy hétfokú skála segítségével adja meg, ahol az 1-es "egyáltalán nem igaz rám", a 7-es pedig "teljes mértékben igaz rám" értelemben szerepel!

\begin{tabular}{|c|c|c|c|c|c|c|c|}
\hline & $\begin{array}{l}1- \\
\text { egyáltalán } \\
\text { nem igaz } \\
\text { rám }\end{array}$ & 2 & 3 & 4 & 5 & 6 & $\begin{array}{l}\text { 7- teljes } \\
\text { mértékben } \\
\text { igaz rám }\end{array}$ \\
\hline $\begin{array}{l}\text { Sok időt töltök természeti } \\
\text { környezetben (erdő, hegyvidék, } \\
\text { puszta, tópart, tengerpart). }\end{array}$ & $\bigodot_{1}$ & $\begin{array}{c}\odot \\
2\end{array}$ & $\begin{array}{c}\odot \\
3\end{array}$ & $\bigodot_{4}$ & $\begin{array}{c}\odot \\
5\end{array}$ & $\begin{array}{c}\odot \\
6\end{array}$ & $\Theta_{7}$ \\
\hline $\begin{array}{l}\text { Úgy tekintek magamra, mint aki a } \\
\text { természet része, nem független } \\
\text { tőle. }\end{array}$ & $\odot_{1}$ & $\begin{array}{c}\odot \\
2\end{array}$ & $\begin{array}{c}\odot \\
3\end{array}$ & $\odot$ & $\begin{array}{c}\odot \\
5\end{array}$ & $\odot$ & $\Theta_{7}$ \\
\hline $\begin{array}{l}\text { Ha lenne elég időm vagy pénzem, } \\
\text { egy részét biztosan arra szánnám, } \\
\text { hogy környezetvédelmi ügyekkel } \\
\text { foglalkozzam. }\end{array}$ & $\odot_{1}$ & $\begin{array}{c}\odot \\
2\end{array}$ & $\begin{array}{c}\odot \\
3\end{array}$ & $\odot$ & $\begin{array}{c}\odot \\
5\end{array}$ & $\odot$ & $\Theta_{7}$ \\
\hline $\begin{array}{l}\text { Ha kiborultam, vagy csak } \\
\text { stresszes vagyok, jobban érzem } \\
\text { magam, ha kis időt a szabadban } \\
\text { tölthetek élvezve a természetet. }\end{array}$ & $\bigodot_{1}$ & $\begin{array}{c}\odot \\
2\end{array}$ & $\odot$ & $\odot$ & $\begin{array}{c}\odot \\
5\end{array}$ & $\odot$ & $\Theta_{7}$ \\
\hline $\begin{array}{l}\text { Érzem, sok közös vonásom van } \\
\text { más élőlényekkel. }\end{array}$ & $\odot_{1}$ & $\begin{array}{c}\odot \\
2\end{array}$ & $\begin{array}{c}\odot \\
3\end{array}$ & $\odot$ & $\begin{array}{c}\odot \\
5\end{array}$ & $\begin{array}{c}\odot \\
6\end{array}$ & $\Theta_{7}$ \\
\hline $\begin{array}{l}\text { A Földdel szembeni } \\
\text { felelösségteljes viselkedés, azaz a } \\
\text { fenntartható életmód követése } \\
\text { része az erkölcsi kódexemnek. }\end{array}$ & $\odot_{1}$ & $\begin{array}{c}\odot \\
2\end{array}$ & $\odot$ & $\odot$ & $\begin{array}{c}\odot \\
5\end{array}$ & $\odot$ & $\Theta_{7}$ \\
\hline $\begin{array}{l}\text { Minden gyermek nevelésének } \\
\text { fontos része kellene, hogy legyen } \\
\text { a természet világának } \\
\text { megismerése. }\end{array}$ & $\odot_{1}$ & $\begin{array}{c}\odot \\
2\end{array}$ & $\begin{array}{c}\odot \\
3\end{array}$ & $\odot$ & $\begin{array}{c}\odot \\
5\end{array}$ & $\odot$ & $\Theta_{7}$ \\
\hline $\begin{array}{l}\text { Inkább élnék egy szép kilátással } \\
\text { rendelkező kisebb szobában vagy } \\
\text { házban, mint egy olyan szobában, } \\
\text { vagy házban, amely nagyobb, de } \\
\text { már épületekre néz. }\end{array}$ & $\odot_{1}$ & $\begin{array}{c}\odot \\
2\end{array}$ & $\odot$ & $\bigodot_{4}$ & $\begin{array}{c}\odot \\
5\end{array}$ & $\odot$ & $\Theta_{7}$ \\
\hline $\begin{array}{l}\text { Úgy érezném, életem fontos része } \\
\text { hiányzik, ha nem tudnék időröl- } \\
\text { idöre kimenni a szabadba és } \\
\text { élvezni a természetet. }\end{array}$ & $\odot_{1}$ & $\begin{array}{c}\odot \\
2\end{array}$ & $\begin{array}{c}\odot \\
3\end{array}$ & $\odot$ & $\begin{array}{c}\odot \\
5\end{array}$ & $\begin{array}{c}\odot \\
6\end{array}$ & $\Theta_{7}$ \\
\hline $\begin{array}{l}\text { Még nem láttam olyan müvészeti } \\
\text { alkotást, amely annyira gyönyörü } \\
\text { lenne, mint a természet olyan } \\
\text { csodái, mint a naplemente vagy } \\
\text { egy hegylánc. }\end{array}$ & $\odot_{1}$ & $\begin{array}{c}\odot \\
2\end{array}$ & $\begin{array}{c}\odot \\
3\end{array}$ & $\odot$ & $\begin{array}{c}\odot \\
5\end{array}$ & $\odot$ & $\Theta_{7}$ \\
\hline $\begin{array}{l}\text { Úgy érzem, spirituális feltöltődést } \\
\text { jelent számomra a természet } \\
\text { élménye. }\end{array}$ & $\odot_{1}$ & $\begin{array}{c}\odot \\
2\end{array}$ & $\underset{3}{\odot}$ & $\odot_{4}$ & $\begin{array}{c}\odot \\
5\end{array}$ & $\underset{6}{\odot}$ & $\Theta_{7}$ \\
\hline
\end{tabular}


K16. Kérjük, a következőkben jelölje, hogy mi a véleménye az alábbi állításokkal kapcsolatban! Kérjüik, válaszát egy ötfokú skála segítségével adja meg, ahol az 1-es "egyáltalán nem értek egyet", az 5-ös pedig "teljes mértékben egyetértek" értelemben szerepel!

\begin{tabular}{|c|c|c|c|c|c|}
\hline & $\begin{array}{l}\text { 1- egyáltalán } \\
\text { nem értek } \\
\text { egyet }\end{array}$ & 2 & 3 & 4 & $\begin{array}{l}\text { 5- teljes } \\
\text { mértékben } \\
\text { egyetértek }\end{array}$ \\
\hline $\begin{array}{l}\text { Környezettudatos fogyasztóként gondolok } \\
\text { magamra. }\end{array}$ & $\bigcirc_{1}$ & $(9$ & $\left(\begin{array}{c}0 \\
3\end{array}\right.$ & $(9$ & $\Theta_{5}$ \\
\hline $\begin{array}{l}\text { Úgy gondolok magamra, mint aki } \\
\text { komolyan aggódik a környezeti } \\
\text { problémák miatt. }\end{array}$ & $\odot_{1}$ & $(9$ & $\left(\begin{array}{c}3 \\
3\end{array}\right.$ & $(9$ & $\Theta_{5}$ \\
\hline $\begin{array}{l}\text { Zavarban lennék, ha úgy tekintenének } \\
\text { rám, mint aki környezetbarát életmódot } \\
\text { folytat. }\end{array}$ & $\Theta_{1}$ & $(9$ & $\underset{3}{9}$ & $(9$ & $\Theta_{5}$ \\
\hline $\begin{array}{l}\text { Nem szeretném, hogy a családom, vagy a } \\
\text { barátaim a környezeti problémák iránt } \\
\text { aggódó személyként gondoljanak rám. }\end{array}$ & $\odot_{1}$ & $(9$ & $\left(\begin{array}{c}3 \\
3\end{array}\right.$ & $(9$ & $\Theta_{5}$ \\
\hline
\end{tabular}


A következőkben az önkéntes munkavégzéssel kapcsolatban teszünk fel kérdéseket.

K18. Az önkéntesség olyan tevékenység, melyet egyénileg vagy csoportosan, rendszeresen vagy alkalmanként, belföldön vagy külföldön a közös jó érdekében személyes akaratból végeznek anyagi ellenszolgáltatás nélkül. Az önkéntes tevékenység közvetlen anyagi haszonnal nem jár annak végzője számára, továbbá az önkéntes nem helyettesíti a fizetett munkaerőt.

Ön végzett már önkéntes munkát?
1. igen
2. nem

K19. Hol végzett/végez Ön önkéntes munkát?

1. belföldön
2. külföldön

K20. Milyen rendszerességgel végez Ön önkéntes munkát?
(a) 1. Ritkábban, mint évente
(- Évente egyszer
3. Negyedévente egyszer
(-) Havonta egyszer
(อ) Hetente
6. Heti egy alkalomnál többször

K21. Kérjük adja meg, hogy hol, millyen szervezetnél végzett önkéntes munkát?

1.
2.

K22. Kérjük adja meg, milyen tevékenységet végzett önkéntes munkája/munkái során?

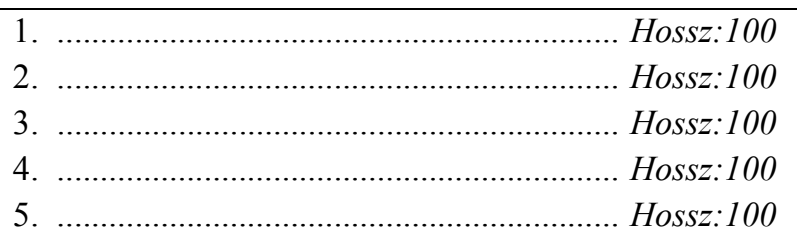

K2122. Kérjük adja meg, hogy hol és milyen tevékenységet végzett önkéntes munkája/munkái során?

\begin{tabular}{|c|c|c|}
\hline & Szervezet & Végzett tevékenység \\
\hline & $\ldots \ldots$ & $\ldots \ldots$ \\
\hline & $\ldots \ldots$. & $\ldots \ldots$. \\
\hline & $\ldots \ldots$ & $\ldots \ldots$ \\
\hline
\end{tabular}




\begin{tabular}{|l|l|l|}
\hline & $\ldots \ldots$ & $\ldots \ldots$ \\
\hline & $\ldots \ldots$. & $\ldots \ldots$ \\
\hline & $\ldots \ldots$. & $\ldots \ldots$. \\
\hline & $\ldots \ldots$ & $\ldots \ldots$ \\
\hline
\end{tabular}

K23. Kérjük, válassza ki az alábbi legördülő menü segítségével állandó lakóhellyét!

A települést könnyebben kiválaszthatja a menüből, ha lenyitja azt, majd begépeli a településnév egy részét. Ez esetben a menü automatikusan az Ön által megadott településnevet mutatja.
$\odot 1$.

K24. Kérjük, válassza ki az alábbi legördülő menü segítségével ideiglenes lakóhelyét!

A települést könnyebben kiválaszthatja a menüből, ha lenyitja azt, majd begépeli a településnév egy részét. Ez esetben a menü automatikusan az Ön által megadott településnevet mutatja.

1.

K25. Az Ön gyerekkori lakhelye (14 éves korig):
$\Theta$
1. Budapest
(2)
2. Megyeszékhely
3. Város
4. Község, falu

K26. Mi az Ön legmagasabb iskolai végzettsége?
1. Nem befejezett általános iskola
$\odot$ 2. Befejezett általános iskola
3. Befejezett középiskola
(- 4. Befejezett föiskola
(-) 5. Befejezett egyetem

K27. Mi az Ön családi állapota?
(- Egyedülálló
2. Párkapcsolatban van, de nem él együtt
(-) 3. Házas vagy élettársi kapcsolatban él
4. Elvált
(- 5. Özvegy

K28. Hányan élnek összesen, állandó jelleggel a háztartásában Önt is beleértve?

$\begin{array}{ll}\odot & 1.1 \text { fö } \\ \odot & 2.2 \text { fö } \\ \odot & 3.3 \text { fö } \\ \odot & 4.4 \text { fö } \\ \odot & 5.5 \text { fö vagy több }\end{array}$


K29. Hány gyermek ( 18 év alatti személy) él a háztartásban?

1. gyermek

K30. Milyen korúak az Ön háztartásában élő gyerme

K31. Melyik kategóriába sorolná be magát a teljes háztartás nettó havi átlagos jövedelme alapján?

$\odot \quad$ 1. $80.000 \mathrm{Ft}$ alatt

2. $80.000 \mathrm{Ft}-100.000 \mathrm{Ft}$

3. $100.001 \mathrm{Ft}-150.000 \mathrm{Ft}$

4. $150.001 \mathrm{Ft}-200.000 \mathrm{Ft}$

5. $200.001 \mathrm{Ft}-250.000 \mathrm{Ft}$

6. $250.001 \mathrm{Ft}-300.000 \mathrm{Ft}$

7. $300.001 \mathrm{Ft}-350.000 \mathrm{Ft}$

8. $350.001 \mathrm{Ft}-400.000 \mathrm{Ft}$

9. $400.001 \mathrm{Ft}-450.000 \mathrm{Ft}$

10. $450.001 \mathrm{Ft}-500.000 \mathrm{Ft}$

11. $500.000 \mathrm{Ft}$ felett

$\odot$ 12. nem tudom/ nem válaszolok

Köszönjük, hogy válaszaival segíti munkánkat! 
7. SZÁMÚ MELLÉKLET: KONFIRMATORIKUS FAKTORELEMZÉS ÁBRÁJA

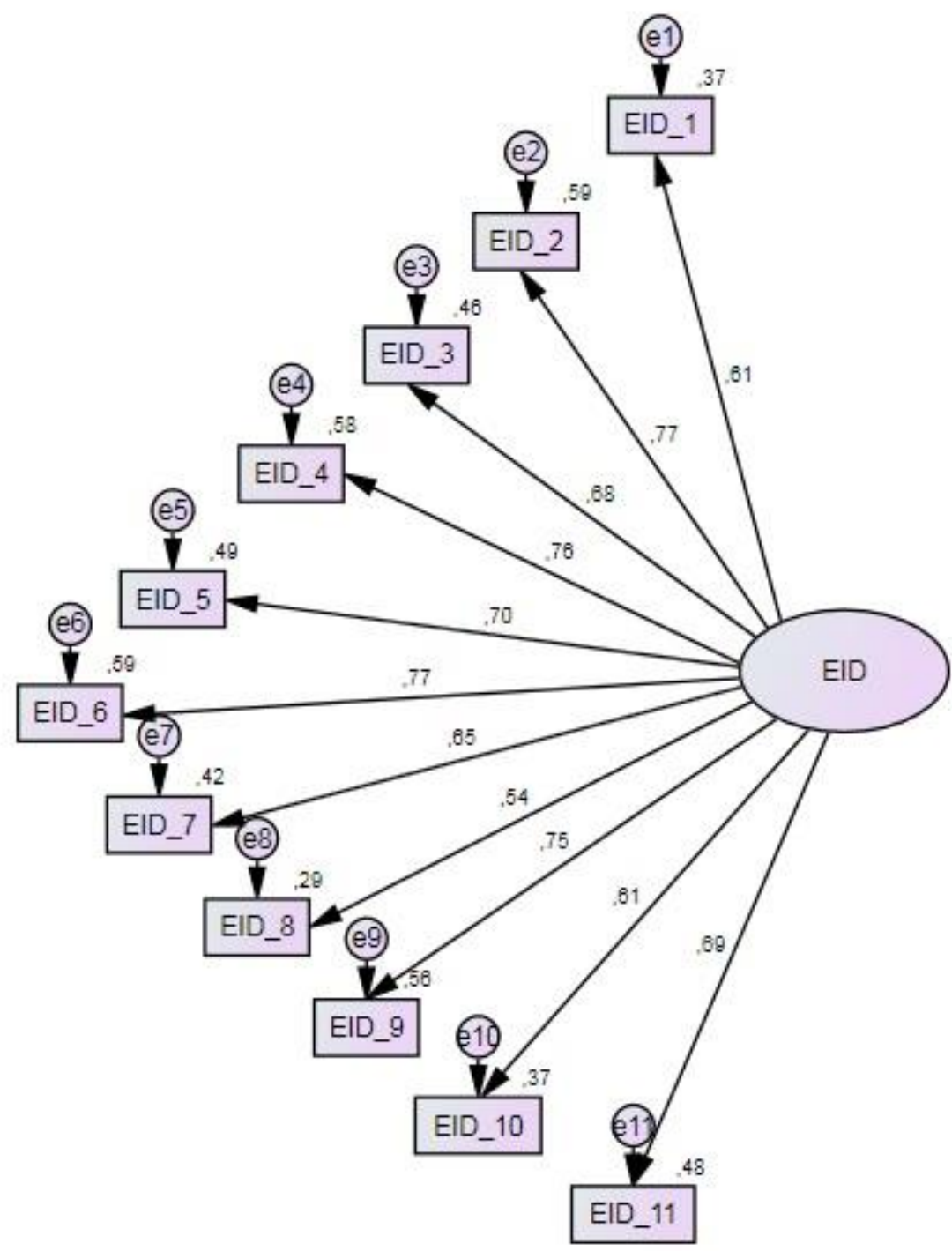


8. SZÁMÚ MELLÉKLET: PCA FAKTORELEMZÉS EREDMÉNYEI

\begin{tabular}{|l|c|}
\hline & Komponens \\
\hline $\begin{array}{l}\text { Sok időt töltök természeti környezetben (erdö, hegyvidék, puszta, tópart, } \\
\text { tengerpart). }\end{array}$ &, 633 \\
\hline Úgy tekintek magamra, mint aki a természet része, nem független töle. &, 782 \\
\hline $\begin{array}{l}\text { Ha lenne elég időm vagy pénzem, egy részét biztosan arra szánnám, hogy } \\
\text { környezetvédelmi ügyekkel foglalkozzam. }\end{array}$ &, 721 \\
\hline $\begin{array}{l}\text { Ha kiborultam, vagy csak stresszes vagyok, segít jobban érezni magam, ha kis idöt } \\
\text { a szabadban tölthetek élvezve a természetet. }\end{array}$ &, 782 \\
\hline Érzem, hogy sok közös vonás van bennem és más élölényekben. &, 737 \\
\hline $\begin{array}{l}\text { A Földdel szembeni felelösségteljes viselkedés, azaz a fenntartható életmód } \\
\text { követése része az erkölcsi kódexemnek. }\end{array}$ &, 793 \\
\hline $\begin{array}{l}\text { Minden gyermek nevelésének fontos része kellene, hogy legyen a természet } \\
\text { világának megismerése. }\end{array}$ &, 705 \\
\hline $\begin{array}{l}\text { Inkább élnék egy szép kilátással rendelkezö kisebb szobában vagy házban, mint egy } \\
\text { olyan szobában, vagy házban, amely nagyobb, de már épületekre néz. }\end{array}$ &, 627 \\
\hline $\begin{array}{l}\text { Úgy érezném, hogy az életem egy fontos része hiányozna, ha nem tudnék idöröl- } \\
\text { időre kimenni a szabadba és élvezni a természetet. }\end{array}$ &, 765 \\
\hline $\begin{array}{l}\text { Még nem láttam olyan művészeti alkotást, amely annyira gyönyörü lenne, mint a } \\
\text { természet olyan csodái, mint a naplemente vagy egy hegylánc. }\end{array}$ &, 669 \\
\hline Úgy érzem, spirituális feltöltődést jelent számomra a természet élménye. &, 710 \\
\hline
\end{tabular}

Forrás: saját szerkesztés 
9. SZÁMÚ MELLÉKLET: KÉT UTAS ANOVA EREDMÉNYEK, FÜGGÖ VÁLTOZÓ EID SKÁLA

a. NEM ÉS KOR FÜGGETLEN VÁLTOZÓK ESETÉBEN

\begin{tabular}{|c|c|c|c|c|c|c|c|}
\hline \multicolumn{8}{|c|}{ ANOVA $^{a}$} \\
\hline & & & \multicolumn{5}{|c|}{ Hierarchical Method } \\
\hline & & & Squares & $\mathrm{df}$ & Mean Square & $\mathrm{F}$ & Sig. \\
\hline \multirow[t]{7}{*}{ EID_score } & \multirow[t]{3}{*}{ Main Effects } & (Combined) & 8438,833 & 4 & 2109,708 & 14,056 & ,000 \\
\hline & & $\mathrm{Nem}$ & 5053,775 & 1 & 5053,775 & 33,671 &, 000 \\
\hline & & Korcsoport & 3385,058 & 3 & 1128,353 & 7,518 &, 000 \\
\hline & $\begin{array}{l}\text { 2-Way } \\
\text { Interactions }\end{array}$ & $\begin{array}{l}\text { Nem * } \\
\text { Korcsoport }\end{array}$ & 687,818 & 3 & 229,273 & 1,528 & ,206 \\
\hline & \multicolumn{2}{|l|}{ Model } & 9126,651 & 7 & 1303,807 & 8,687 &, 000 \\
\hline & \multicolumn{2}{|l|}{ Residual } & 137300,615 & 915 & 150,094 & & \\
\hline & \multicolumn{2}{|l|}{ Total } & 146427,266 & 922 & 158,855 & & \\
\hline
\end{tabular}

a. EID_score by Nem, Korcsoport

\section{Factor Summary ${ }^{\mathrm{a}}$}

\begin{tabular}{|c|c|c|c|}
\hline & \multirow[b]{2}{*}{ Eta } & Beta \\
\hline & & & $\begin{array}{l}\text { Adjusted for } \\
\text { Factors }\end{array}$ \\
\hline \multirow[t]{2}{*}{ EID_score } & $\mathrm{Nem}$ & , 186 & ,201 \\
\hline & Korcsoport & ,133 & ,153 \\
\hline
\end{tabular}

a. EID_score by Nem, Korcsoport

Model Goodness of Fit

\begin{tabular}{|l|r|r|}
\hline & & \\
& $\mathrm{R}$ & R Squared \\
\hline $\begin{array}{l}\text { ElD_score by } \\
\text { Nem, } \\
\text { Korcsoport }\end{array}$ &, 240 &, 058 \\
\hline
\end{tabular}


b. KOR ÉS CSALÁDI ÁLLAPOT FÜGGETLEN VÁLTOZÓK ESETÉBEN

\begin{tabular}{|c|c|c|c|c|c|c|c|}
\hline \multicolumn{8}{|c|}{ ANOVA $^{a}$} \\
\hline & & & \multicolumn{5}{|c|}{ Hierarchical Method } \\
\hline & & & $\begin{array}{c}\text { Sum of } \\
\text { Squares }\end{array}$ & df & Mean Square & $\mathrm{F}$ & Sig. \\
\hline \multirow[t]{7}{*}{ EID_score } & \multirow[t]{3}{*}{ Main Effects } & (Combined) & 5727,199 & 7 & 818,171 & 5,308 &, 000 \\
\hline & & Korcsoport & 2608,872 & 3 & 869,624 & 5,642 & 001 \\
\hline & & $\begin{array}{l}\text { Mi azÖn } \\
\text { családi } \\
\text { állapota? }\end{array}$ & 3118,328 & 4 & 779,582 & 5,058 & , 000 \\
\hline & $\begin{array}{l}\text { 2-Way } \\
\text { Interactions }\end{array}$ & $\begin{array}{l}\text { Korcsoport * } \\
\text { Mi az Ön } \\
\text { családi } \\
\text { állapota? }\end{array}$ & 1239,214 & 10 & 123,921 & ,804 & 625 \\
\hline & \multicolumn{2}{|l|}{ Model } & 6966,413 & 17 & 409,789 & 2,659 & 000 \\
\hline & \multicolumn{2}{|l|}{ Residual } & 139460,853 & 905 & 154,140 & & \\
\hline & \multicolumn{2}{|l|}{ Total } & 146427,266 & 922 & 158,855 & & \\
\hline
\end{tabular}

a. EID_score by Korcsoport, Mi az Ön családi állapota?

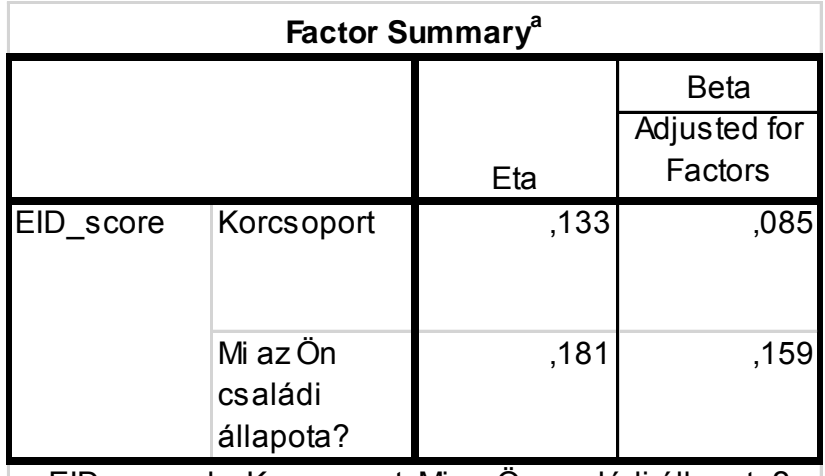

a. EID_score by Korcsoport, Mi az Ön családi állapota?

\section{Model Goodness of Fit}

\begin{tabular}{|c|c|c|}
\hline & $\mathrm{R}$ & R Squared \\
\hline $\begin{array}{l}\text { EID_score by } \\
\text { Korcsoport, } \\
\text { Mi az Ön } \\
\text { családi } \\
\text { állapota? }\end{array}$ & , 198 & ,039 \\
\hline
\end{tabular}


c. NEM ÉS CSALÁDI ÁLLAPOT FÜGGETLEN VÁLTOZÓK ESETÉBEN

\begin{tabular}{|c|c|c|c|c|c|c|c|}
\hline \multicolumn{8}{|c|}{ ANOVA $^{a}$} \\
\hline & & & \multicolumn{5}{|c|}{ Hierarchical Method } \\
\hline & & & $\begin{array}{c}\text { Sum of } \\
\text { Squares }\end{array}$ & df & Mean Square & $\mathrm{F}$ & Sig. \\
\hline \multirow[t]{7}{*}{ EID_score } & \multirow[t]{3}{*}{ Main Effects } & (Combined) & 8660,576 & 5 & 1732,115 & 11,682 &, 000 \\
\hline & & Nem & 5053,775 & 1 & 5053,775 & 34,083 & 000 \\
\hline & & $\begin{array}{l}\text { Mi az Ön } \\
\text { családi } \\
\text { állapota? }\end{array}$ & 3606,801 & 4 & 901,700 & 6,081 &, 000 \\
\hline & $\begin{array}{l}\text { 2-Way } \\
\text { Interactions }\end{array}$ & $\begin{array}{l}\mathrm{Nem}{ }^{*} \mathrm{Mi} \text { az } \\
\text { Ön családi } \\
\text { állapota? }\end{array}$ & 2424,116 & 4 & 606,029 & 4,087 & 003 \\
\hline & \multicolumn{2}{|l|}{ Model } & 11084,692 & 9 & 1231,632 & 8,306 & ,000 \\
\hline & \multicolumn{2}{|l|}{ Residual } & 135342,574 & 913 & 148,278 & & \\
\hline & \multicolumn{2}{|l|}{ Total } & 146427,266 & 922 & 158,855 & & \\
\hline
\end{tabular}

a. EID_score by Nem, Mi az Ön családi állapota?

\section{Factor Summary ${ }^{\mathrm{a}}$}

\begin{tabular}{|c|c|c|c|}
\hline & & Eta & $\begin{array}{c}\text { Beta } \\
\text { Adjusted for } \\
\text { Factors }\end{array}$ \\
\hline \multirow[t]{2}{*}{ EID_score } & Nem & ,186 & ,166 \\
\hline & $\begin{array}{l}\text { Mi azÖn } \\
\text { családi } \\
\text { állapota? }\end{array}$ & ,181 & ,158 \\
\hline
\end{tabular}

a. EID_score by Nem, Mi az Ön családi állapota?

\section{Model Goodness of Fit}

\begin{tabular}{|c|c|c|}
\hline & $\mathrm{R}$ & R Squared \\
\hline $\begin{array}{l}\text { EID_score by } \\
\text { Nem, Mi az } \\
\text { Ön családi } \\
\text { állapota? }\end{array}$ & ,243 & ,059 \\
\hline
\end{tabular}


d. KoR ÉS CSALÁDI ÁLLAPOT FÜGGETLEN VÁLTOZÓK ESETÉBEN

\begin{tabular}{|c|c|c|c|c|c|c|c|}
\hline \multicolumn{8}{|c|}{ ANOVA $^{a}$} \\
\hline & & & \multicolumn{5}{|c|}{ Hierarchical Method } \\
\hline & & & $\begin{array}{c}\text { Sum of } \\
\text { Squares }\end{array}$ & df & Mean Square & $\mathrm{F}$ & Sig. \\
\hline \multirow[t]{7}{*}{ EID_score } & \multirow[t]{3}{*}{ Main Effects } & (Combined) & 5727,199 & 7 & 818,171 & 5,308 & ,000 \\
\hline & & Korcsoport & 2608,872 & 3 & 869,624 & 5,642 & ,001 \\
\hline & & $\begin{array}{l}\text { Mi az Ön } \\
\text { családi } \\
\text { állapota? }\end{array}$ & 3118,328 & 4 & 779,582 & 5,058 &, 000 \\
\hline & $\begin{array}{l}\text { 2-Way } \\
\text { Interactions }\end{array}$ & $\begin{array}{l}\text { Korcsoport * } \\
\text { Mi az Ön } \\
\text { családi } \\
\text { állapota? }\end{array}$ & 1239,214 & 10 & 123,921 & 804 & ,625 \\
\hline & \multicolumn{2}{|l|}{ Model } & 6966,413 & 17 & 409,789 & 2,659 & , 000 \\
\hline & \multicolumn{2}{|l|}{ Residual } & 139460,853 & 905 & 154,140 & & \\
\hline & \multicolumn{2}{|l|}{ Total } & 146427,266 & 922 & 158,855 & & \\
\hline
\end{tabular}

\section{Factor Summary ${ }^{\mathrm{a}}$}

\begin{tabular}{|ll|r|r|}
\hline \multirow{2}{*}{} & & & \multicolumn{2}{|c|}{ Beta } \\
\cline { 3 - 4 } & Eta & $\begin{array}{c}\text { Adjusted for } \\
\text { Factors }\end{array}$ \\
\hline EID_score & Korcsoport &, 133 &, 085 \\
& &, 181 &, 159 \\
& $\begin{array}{l}\text { Mi az Ön } \\
\text { családi } \\
\text { állapota? }\end{array}$ & & \\
\hline
\end{tabular}

a. EID_score by Korcsoport, Mi az Ön családi állapota?

Model Goodness of Fit

\begin{tabular}{|c|c|c|}
\hline & $\mathrm{R}$ & R Squared \\
\hline $\begin{array}{l}\text { EID_score by } \\
\text { Korcsoport, } \\
\text { Mi az Ön } \\
\text { családi } \\
\text { állapota? }\end{array}$ & ,198 & ,039 \\
\hline
\end{tabular}


10. SZÁMÚ MELLÉKLET: REGRESSZIÓ ELEMZÉS AZ ÉRTÉKEK ÉS A KÖRNYEZETI IDENTITÁS VIZSGÁLATÁRA

\begin{tabular}{|c|c|c|c|c|c|c|c|c|c|c|c|c|}
\hline & & EID_score & Nem & Életkor & $\begin{array}{l}\text { Valahová } \\
\text { tartozás }\end{array}$ & $\begin{array}{l}\text { Jó kapcsolat } \\
\text { másokkal }\end{array}$ & $\begin{array}{c}\text { Ön- } \\
\text { megvalósítás }\end{array}$ & Elismertség & $\begin{array}{l}\text { Szórakozás és az } \\
\text { élet élvezete }\end{array}$ & Biztonság & Önbecsülés & $\begin{array}{c}\text { Az alkotás } \\
\text { érzése }\end{array}$ \\
\hline \multirow{11}{*}{ 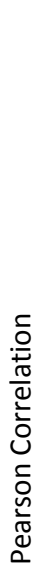 } & EID_score & 1,000 & 199 & 154 & ,208 & ,208 & ,293 & 185 & 102 & ,254 & ,320 & ,360 \\
\hline & Nem & 199 & 1,000 &,- 097 & ,231 & 130 & 143 & 139 &,- 057 & ,248 & ,233 & ,004 \\
\hline & Életkor & 154 &,- 097 & 1,000 & 109 & , 048 &,- 028 &,- 036 &,- 187 & 120 & ,057 & 150 \\
\hline & Valahová tartozás & ,208 & ,231 & ,109 & 1,000 & ,531 & ,370 & ,412 & ,221 & ,482 & ,357 & ,237 \\
\hline & Jó kapcsolat másokkal & ,208 & ,130 & ,048 & ,531 & 1,000 & ,432 & ,404 & ,343 & ,418 & ,413 & ,300 \\
\hline & Önmegvalósítás & ,293 & ,143 &,- 028 & ,370 & ,432 & 1,000 & ,471 & ,401 & ,335 & ,561 & ,501 \\
\hline & Elismertség & ,185 & 139 & -,036 & ,412 & ,404 & ,471 & 1,000 & ,323 & ,380 & ,410 & ,355 \\
\hline & $\begin{array}{l}\text { Szórakozás és az élet } \\
\text { élvezete }\end{array}$ & 102 &,- 057 & -187 & 221 & ,343 & ,401 & ,323 & 1,000 & 177 & 316 & ,252 \\
\hline & Biztonság & 254 & ,248 & ,120 & ,482 & ,418 & ,335 & ,380 & 177 & 1,000 & ,418 & ,245 \\
\hline & Önbecsülés & ,320 & ,233 & ,057 & ,357 & ,413 & ,561 & ,410 & ,316 & 418 & 1,000 & 408 \\
\hline & Az alkotás érzése & ,360 & ,004 & 150 & ,237 & ,300 & ,501 & ,355 & ,252 & ,245 & ,408 & 1,000 \\
\hline \multirow{11}{*}{ 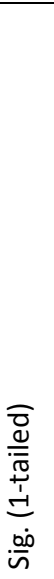 } & EID_score & & , 000 & , 000 & ,000 & ,000 & ,000 & ,000 & 002 & 000 & ,000 & , 000 \\
\hline & Nem & 000 & . & ,003 & ,000 & ,000 & ,000 & ,000 & 055 & 000 & ,000 & ,456 \\
\hline & Életkor & 000 & ,003 & . & 001 & ,086 & ,213 & 157 & 000 & 000 & ,054 & ,000 \\
\hline & Valahová tartozás & 000 & ,000 & ,001 & . & ,000 & ,000 & ,000 & 000 & 000 & ,000 & , 000 \\
\hline & Jó kapcsolat másokkal & ,000 & ,000 & ,086 & 000 & . & 000 & ,000 & ,000 & ,000 & 000 & 000 \\
\hline & Önmegvalósítás & ,000 & ,000 & ,213 & ,000 & ,000 & & ,000 & ,000 & , 000 & ,000 & ,000 \\
\hline & Elismertség & ,000 & , 000 & 157 & ,000 & , 000 & ,000 & . & 000 & , 000 & ,000 & , 000 \\
\hline & $\begin{array}{l}\text { Szórakozás és az élet } \\
\text { élvezete }\end{array}$ & ,002 & ,055 & ,000 & ,000 & ,000 & ,000 & ,000 & & ,000 & ,000 & ,000 \\
\hline & Biztonság & ,000 & ,000 & ,000 & ,000 & ,000 & ,000 & ,000 & ,000 & . & ,000 & ,000 \\
\hline & Önbecsülés & ,000 & , 000 & , 054 & ,000 & ,000 & ,000 & ,000 & , 000 & , 000 & . & , 000 \\
\hline & Az alkotás érzése & 000 & ,456 & ,000 & ,000 & ,000 & , 000 & , 000 & 000 & , 000 & , 000 & \\
\hline
\end{tabular}




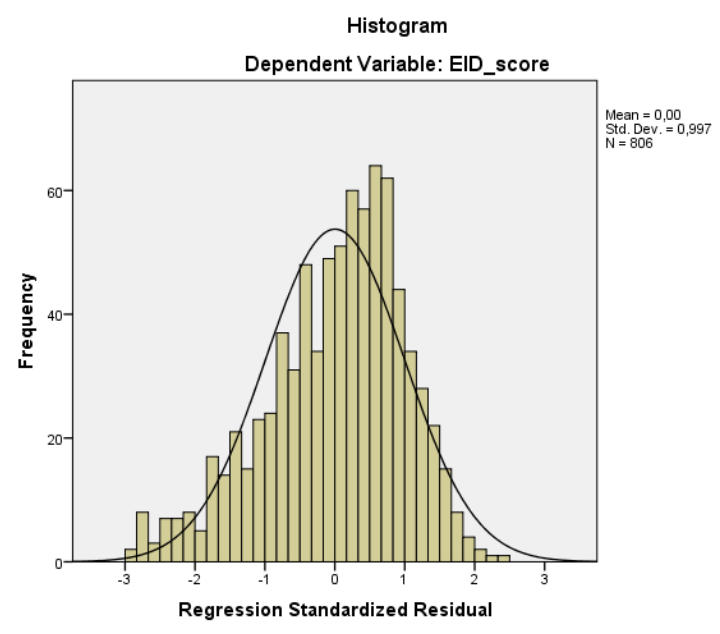

Normal P-P Plot of Regression Standardized Residual

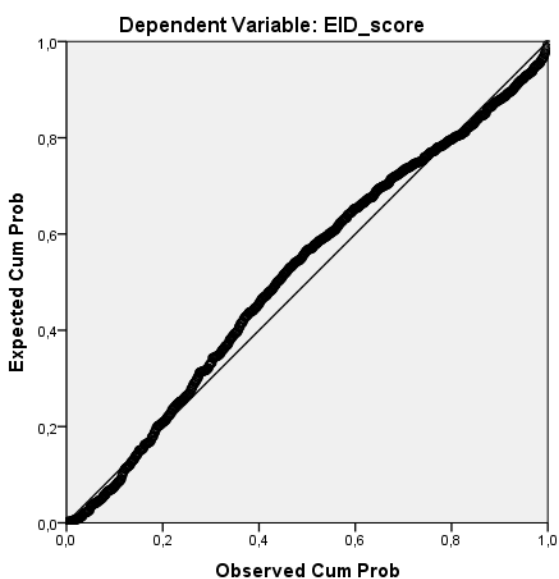

Scatterplot

Dependent Variable: EID_score

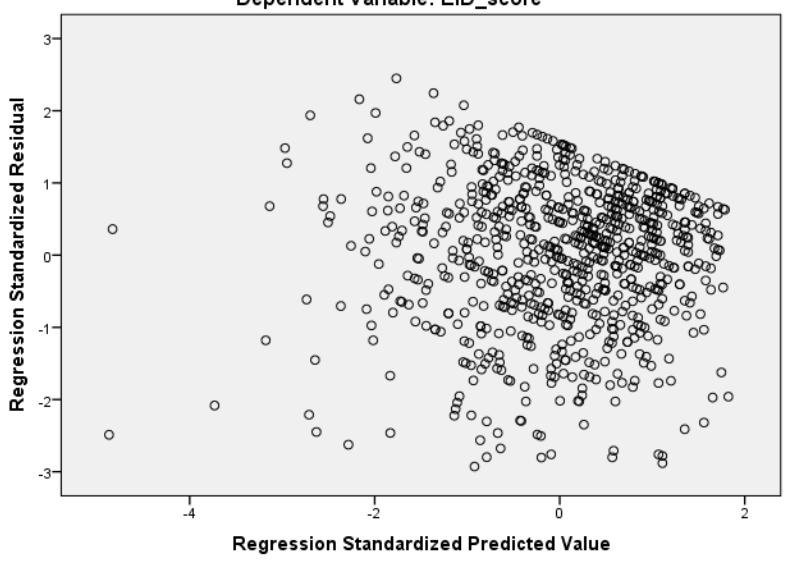


11. SZÁMÚ MELLÉKLET: ÚTELEMZÉS OUTPUT TÁBLÁI
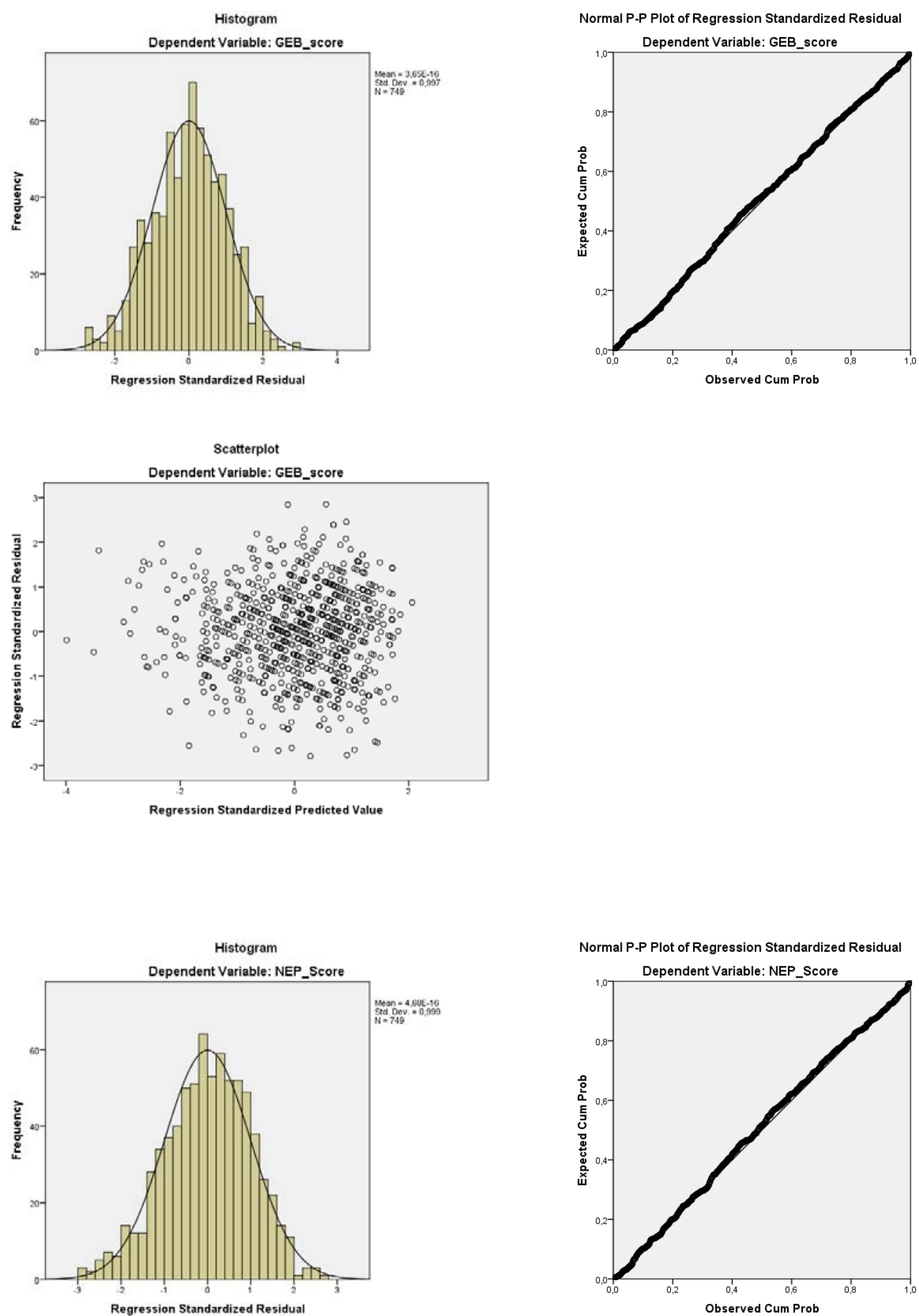

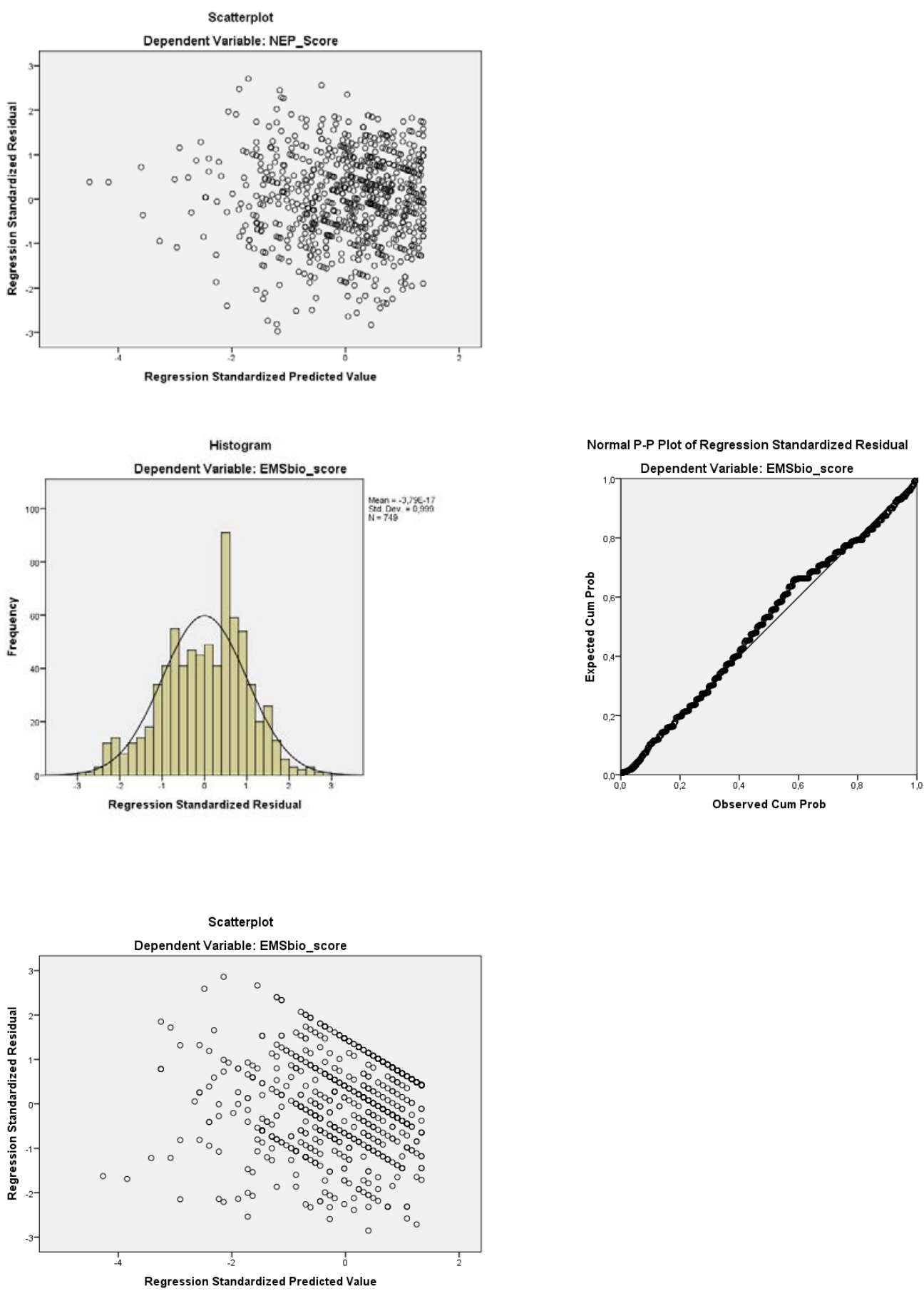

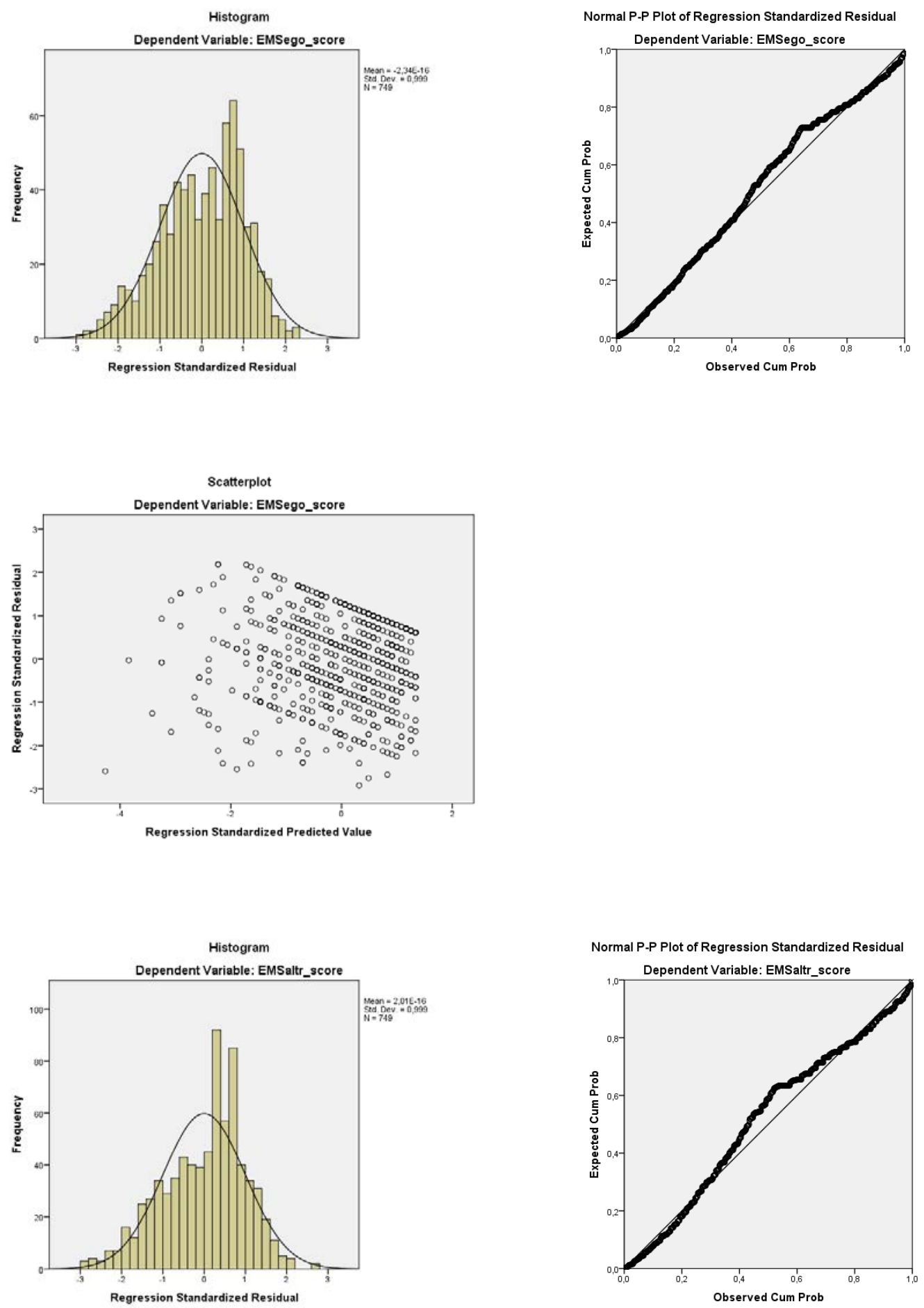
Scatterplo

Dependent Variable: EMSaltr_score

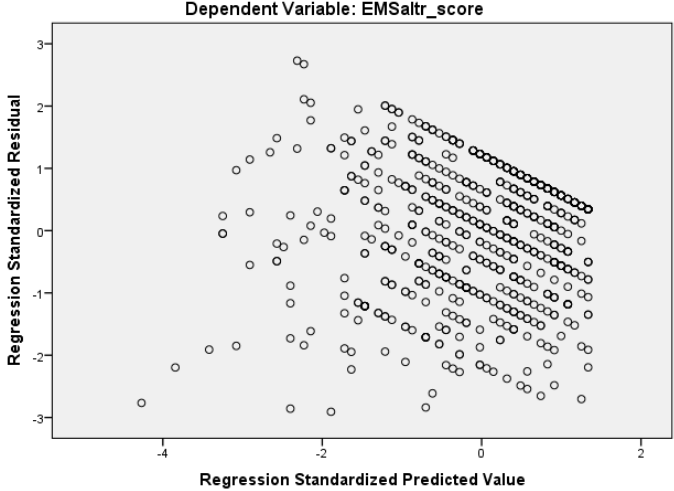

Histogram

Dependent Variable: PNego_score

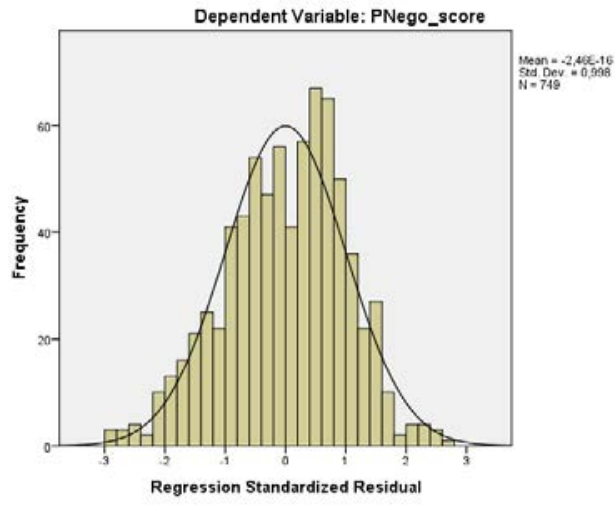

Scatterplot

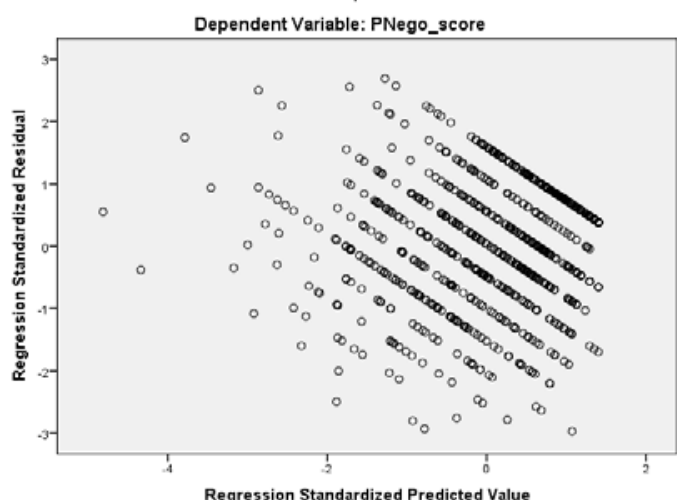

Normal P-P Plot of Regression Standardized Residual

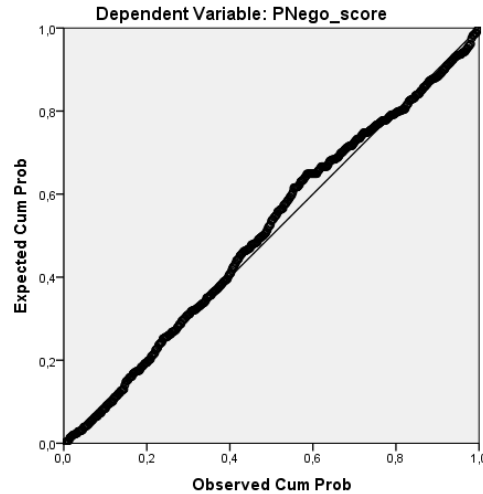



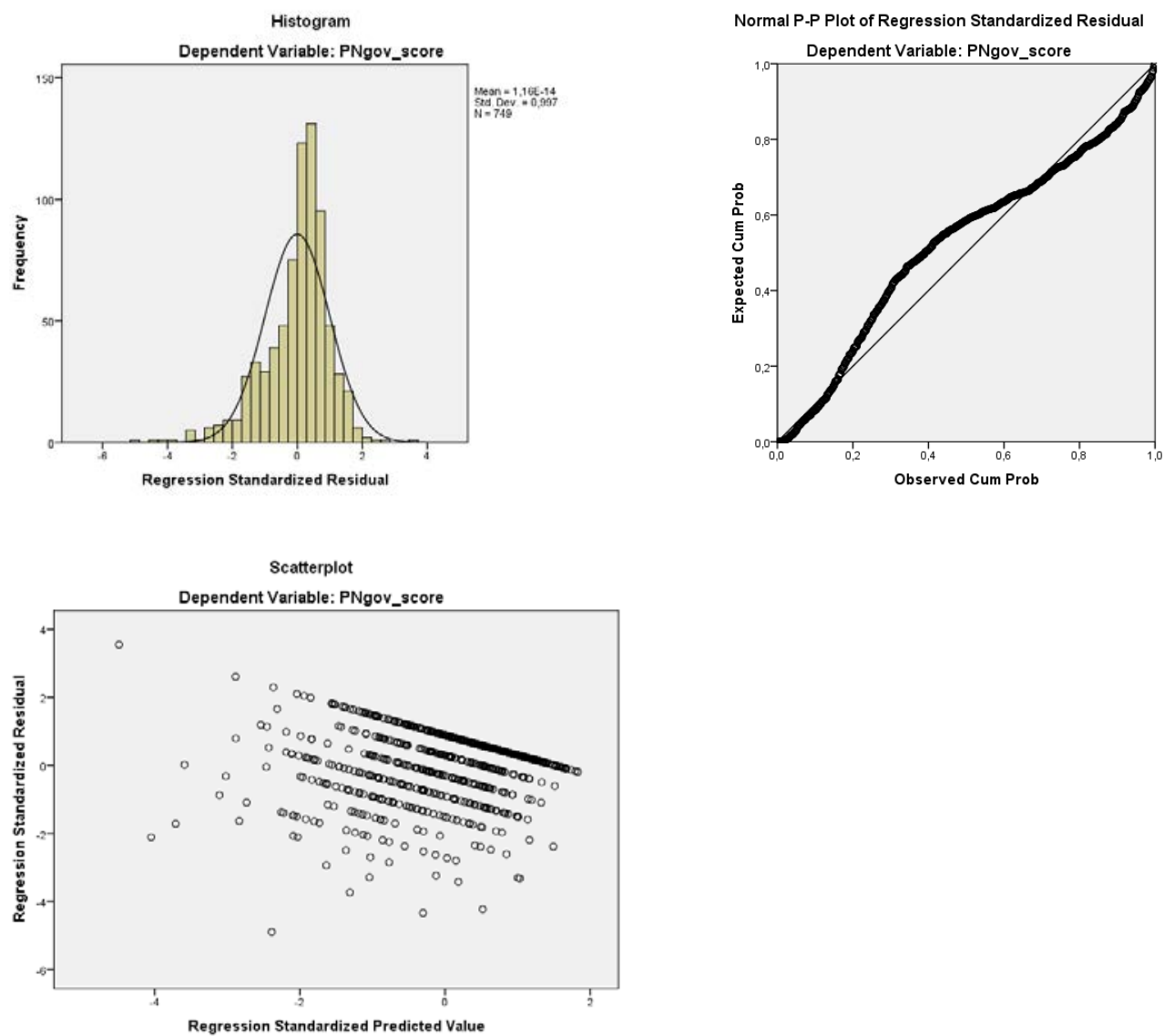

Normal P.P Plot of Regression Standardized Residual
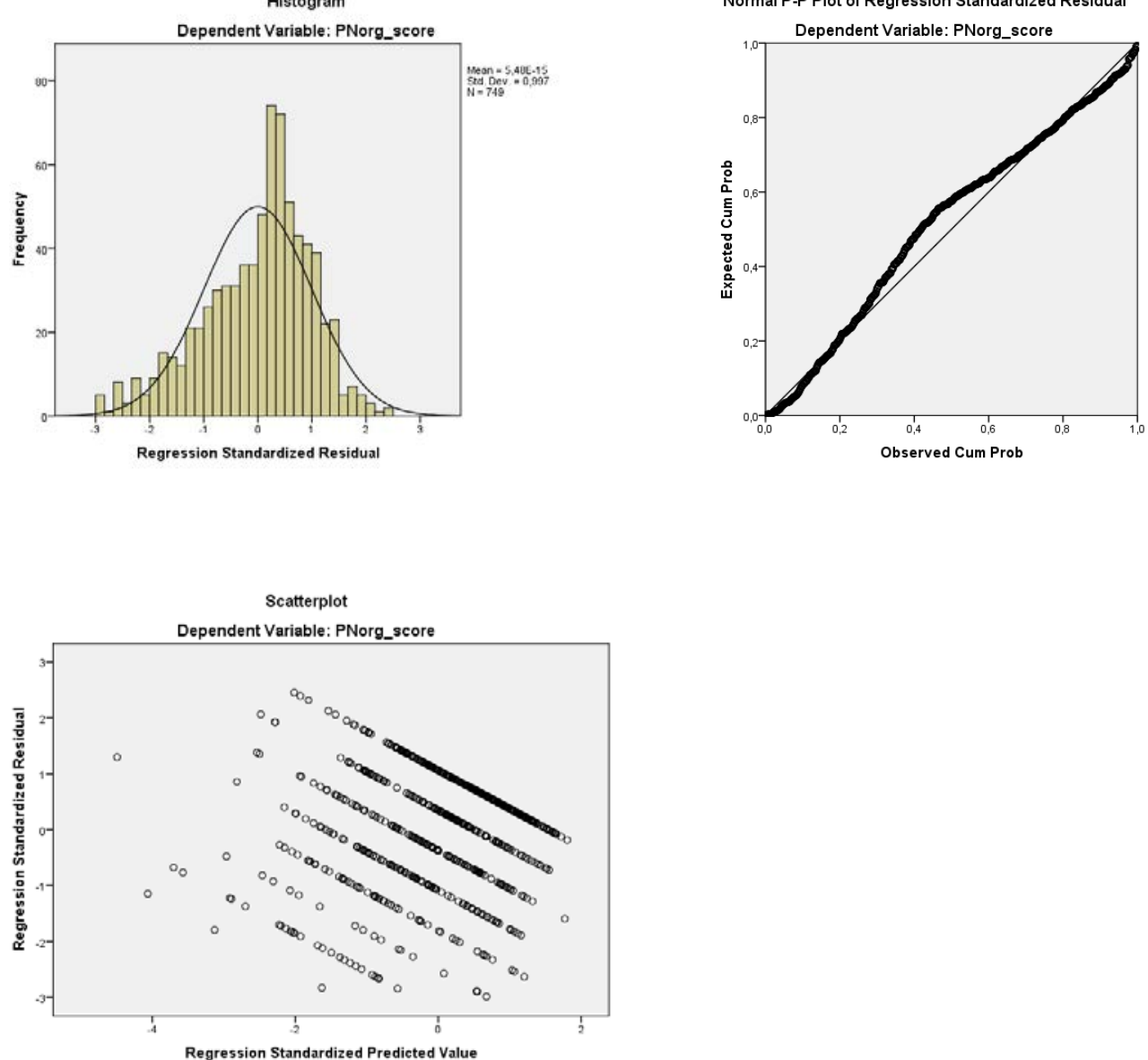
DOI: 10.14267/phd.2015036 